\title{
Isotopic and Fuel Lattice Parameter Trends in Extended Enrichment and Higher Burnup LWR Fuel
}

\section{Vol. I: PWR Fuel}

Robert Hall

Riley Cumberland Ryan Sweet

William A. Wieselquist

February 2021 


\title{
DOCUMENT AVAILABILITY
}

Reports produced after January 1, 1996, are generally available free via US Department of Energy (DOE) SciTech Connect.

Website www.osti.gov

Reports produced before January 1, 1996, may be purchased by members of the public from the following source:

\author{
National Technical Information Service \\ 5285 Port Royal Road \\ Springfield, VA 22161 \\ Telephone 703-605-6000 (1-800-553-6847) \\ TDD 703-487-4639 \\ Fax 703-605-6900 \\ E-mail info@ntis.gov \\ Website http://classic.ntis.gov/
}

Reports are available to DOE employees, DOE contractors, Energy Technology Data Exchange representatives, and International Nuclear Information System representatives from the following source:

Office of Scientific and Technical Information

PO Box 62

Oak Ridge, TN 37831

Telephone 865-576-8401

Fax 865-576-5728

E-mail reports@osti.gov

Website http://www.osti.gov/contact.html

This report was prepared as an account of work sponsored by an agency of the United States Government. Neither the United States Government nor any agency thereof, nor any of their employees, makes any warranty, express or implied, or assumes any legal liability or responsibility for the accuracy, completeness, or usefulness of any information, apparatus, product, or process disclosed, or represents that its use would not infringe privately owned rights. Reference herein to any specific commercial product, process, or service by trade name, trademark, manufacturer, or otherwise, does not necessarily constitute or imply its endorsement, recommendation, or favoring by the United States Government or any agency thereof. The views and opinions of authors expressed herein do not necessarily state or reflect those of the United States Government or any agency thereof. 
Nuclear Energy and Fuel Cycle Division

\section{ISOTOPIC AND FUEL LATTICE PARAMETER TRENDS IN EXTENDED ENRICHMENT AND HIGHER BURNUP LWR FUEL \\ VOL. I: PWR FUEL}

Robert Hall, Riley Cumberland, Ryan Sweet, William A. Wieselquist

Date Published: February 2021

Prepared by

OAK RIDGE NATIONAL LABORATORY

Oak Ridge, TN 37831-6283

managed by

UT-BATTELLE, LLC

for the

US DEPARTMENT OF ENERGY

under contract DE-AC05-00OR22725 


\section{CONTENTS}

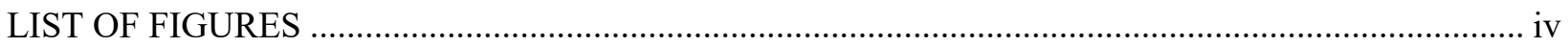

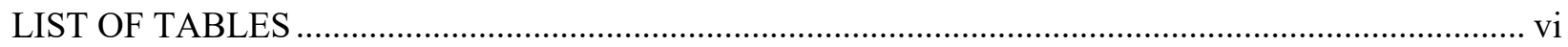

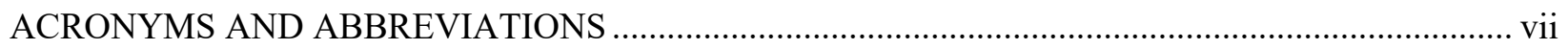

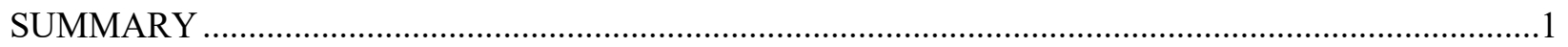

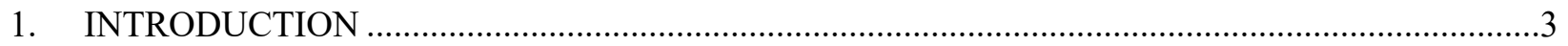

1.1 EXPECTED EFFECTS OF HBU AND EE ON FUEL MANAGEMENT …...........................4

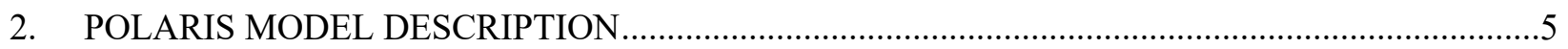

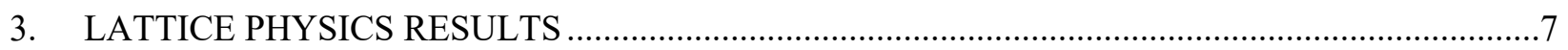

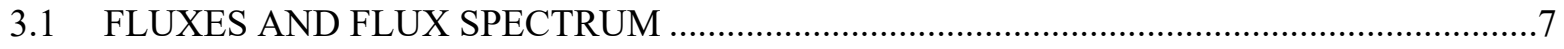

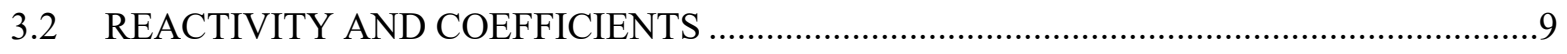

3.3 CROSS SECTION LIBRARY AND CODE VERSION EFFECTS ….................................13

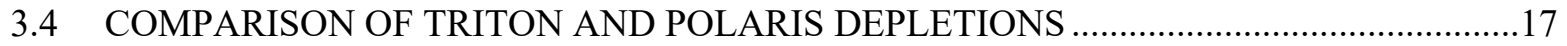

3.5 PIN POWER AND BURNUP DISTRIBUTIONS ….........................................................

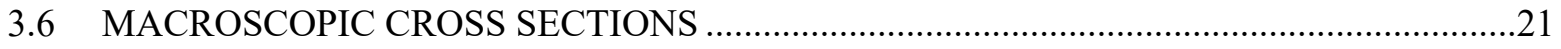

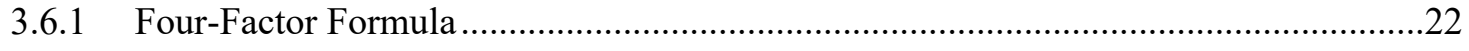

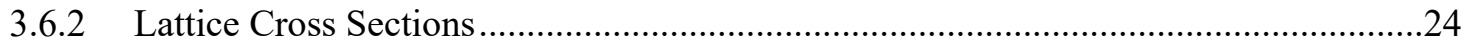

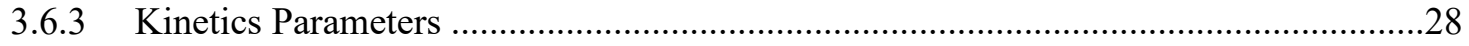

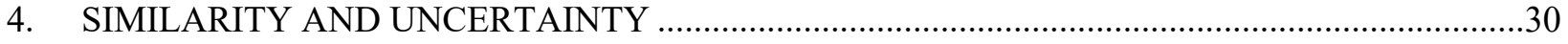

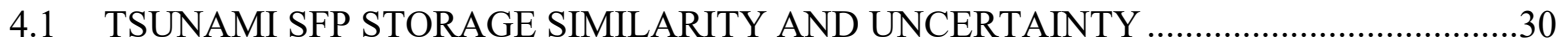

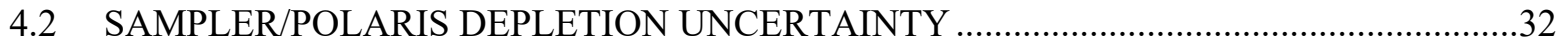

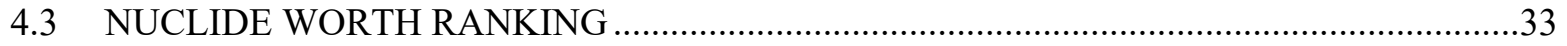

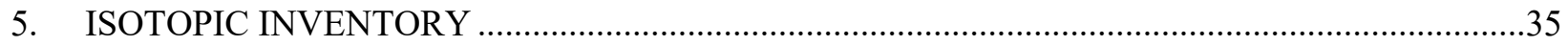

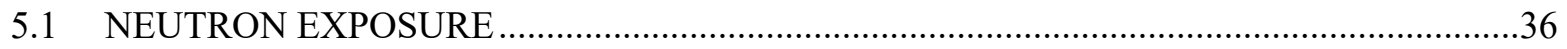

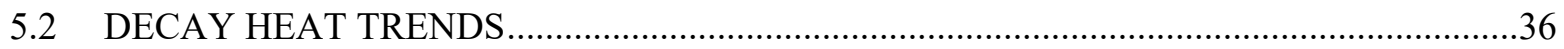

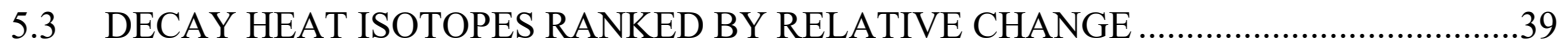

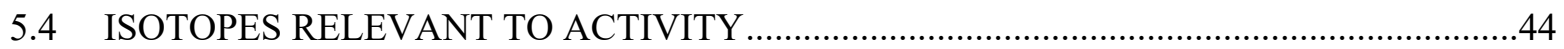

5.5 ISOTOPES RELEVANT TO ACCIDENT RELEASE SOURCE TERM ...............................48

5.6 ISOTOPES RELEVANT TO RADIATION SHIELDING SOURCE TERM ........................49

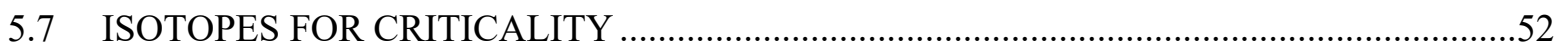

5.8 IMPACT OF CROSS SECTION LIBRARY ON ISOTOPIC PREDICTIONS........................56

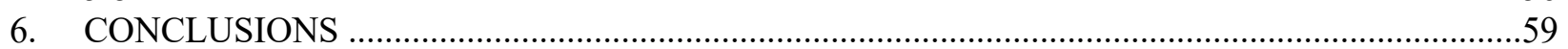

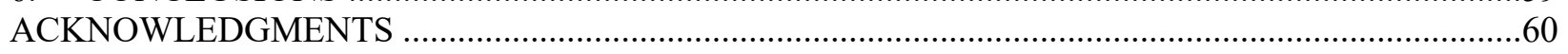

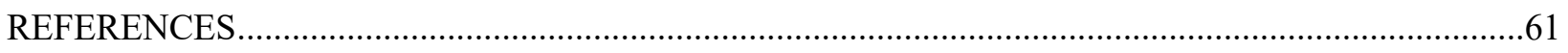

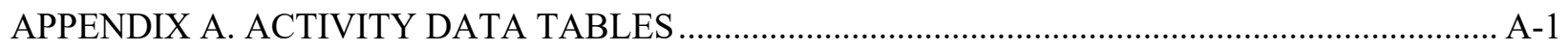

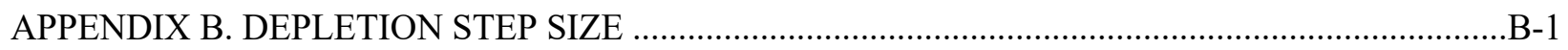

APPENDIX C. COMPUTER CODE INPUT AND OUTPUT …........................................................... 


\section{LIST OF FIGURES}

Figure 1. Westinghouse $17 \times 17104$ IFBA model (three radial rings per fuel pellet) . ..............................6

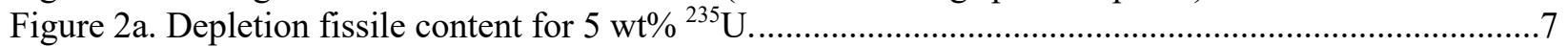

Figure 2b. Depletion fissile content for $8 \mathrm{wt} \%{ }^{235} \mathrm{U}$. ............................................................ 7

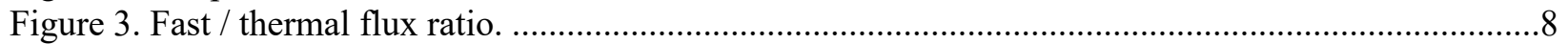

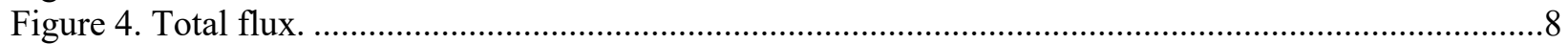

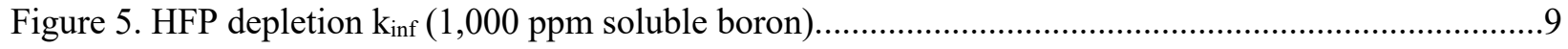

Figure 6. HFP depletion $\Delta \mathrm{k}$ relative to $5 \mathrm{wt} \%$ (0 ppm soluble boron). ................................................10

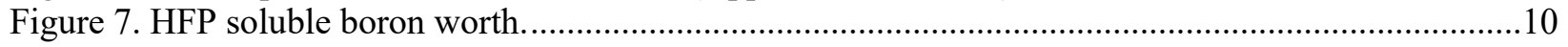

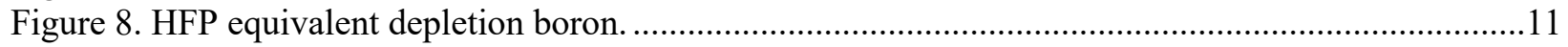

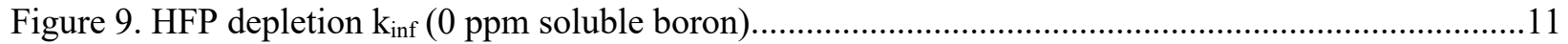

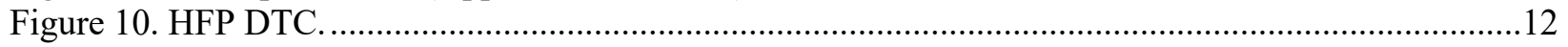

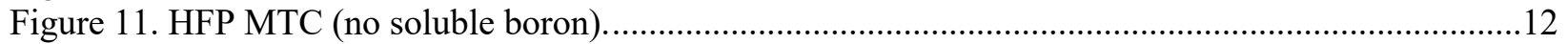

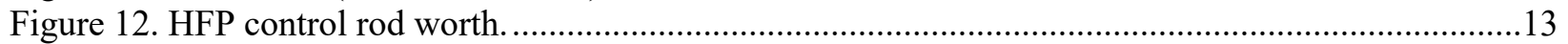

Figure 13. HFP $\mathrm{k}_{\text {inf }}$ cross section library difference $\left(\mathrm{k}_{\text {inf }} 56\right.$ - and $\mathrm{k}_{\text {inf }} 252$-group)...................................14

Figure 14. HFP DTC cross section library difference (56- and 252-group) ........................................14

Figure 15. HFP MTC cross section library difference (56- and 252-group)..........................................15

Figure 16. HFP BW cross section library difference (56 - and 252-group)..........................................15

Figure 17. HFP control rod worth cross section library difference (56-group vs 252-group)...................16

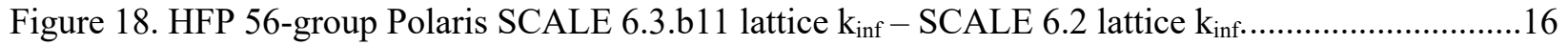

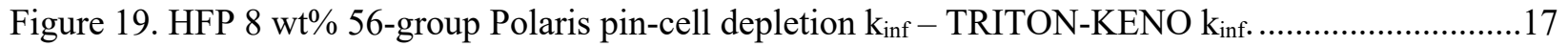

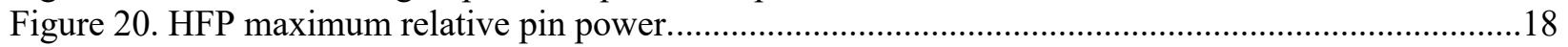

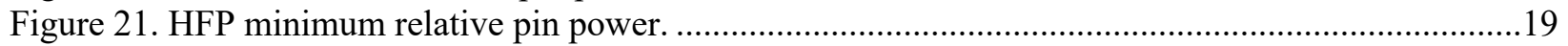

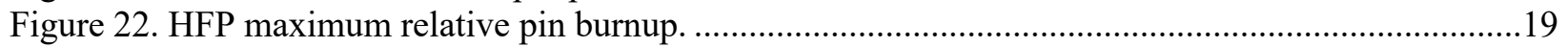

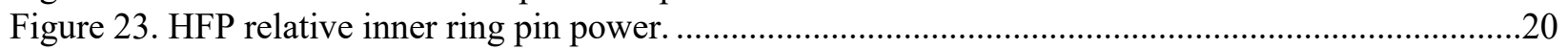

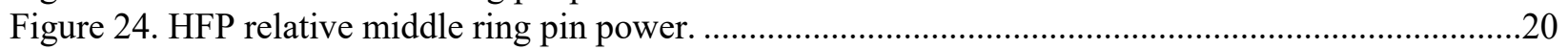

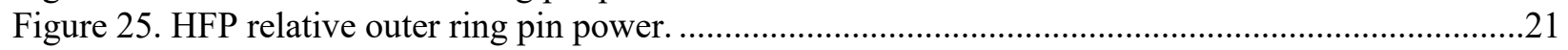

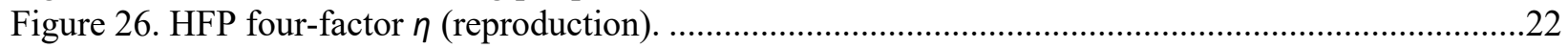

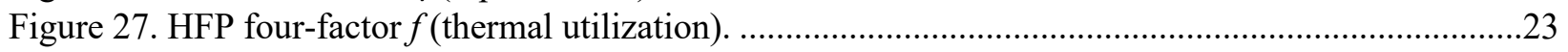

Figure 28. HFP four factor $p$ (resonance escape probability)..............................................................23

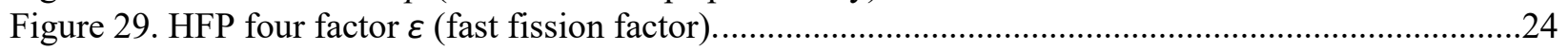

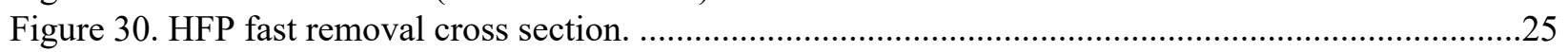

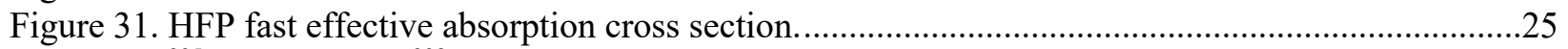

Figure 32. ${ }^{235} \mathrm{U}$ (black) and ${ }^{238} \mathrm{U}$ (red) absorption cross section (barns) vs energy (eV). ........................26

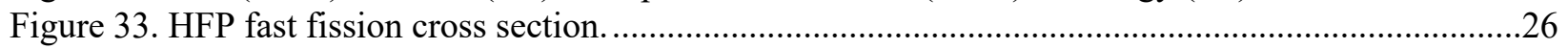

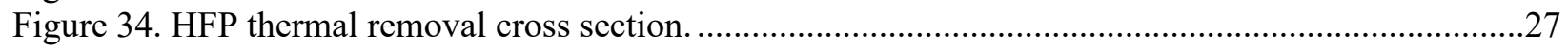

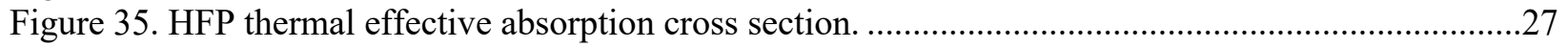

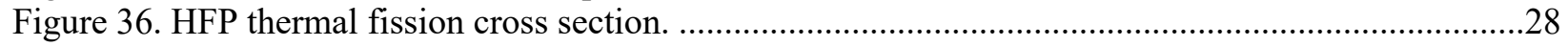

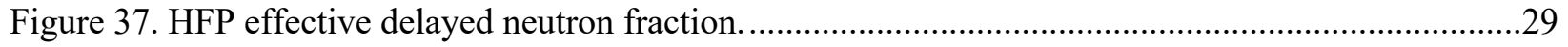

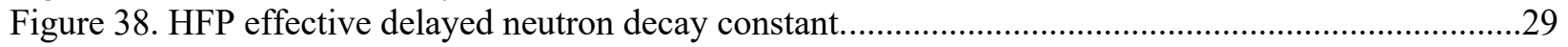

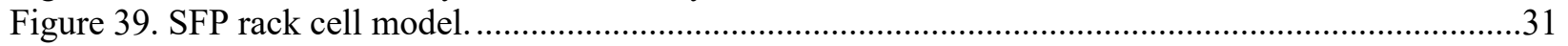

Figure 40. HFP pin-cell Polaris model perturbed depletion $\mathrm{k}_{\text {inf }}$ uncertainty...........................................32

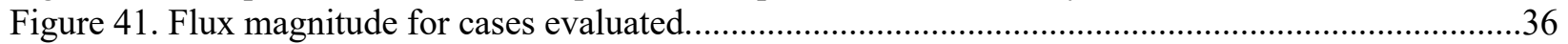

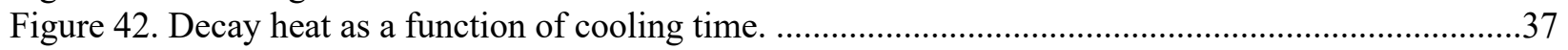

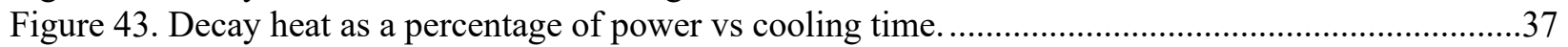

Figure 44. Decay heat relative difference from $60 \mathrm{GWd}$ /MTU $5 \mathrm{wt} \%$ case.............................................38

Figure 44. Decay heat absolute difference from $60 \mathrm{GWd}$ /MTU $5 \mathrm{wt} \%$ case. ..........................................39

Figure 45. In-core abundances of ${ }^{144} \mathrm{Pr}$ beta chain isotopes for $5 \mathrm{wt} \%$ initial enrichment.........................41

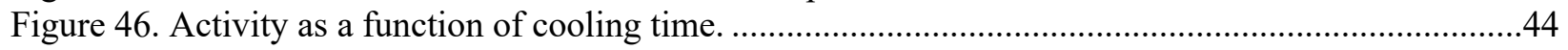




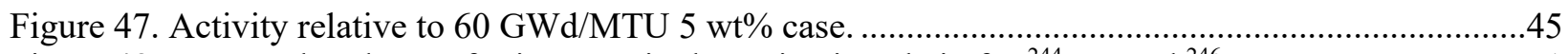

Figure 48. In-core abundances for isotopes in the activation chain for ${ }^{244} \mathrm{Cm}$ and ${ }^{246} \mathrm{Cm}$......................51

Figure B.1. Reactivity effect of depletion step size. .......................................................................... 


\section{LIST OF TABLES}

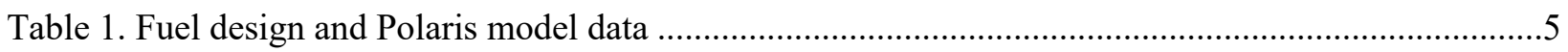

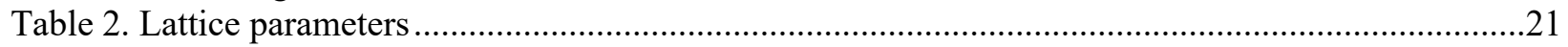

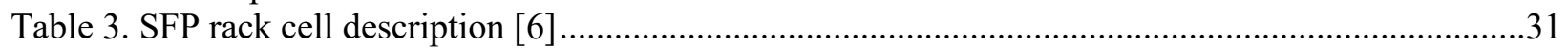

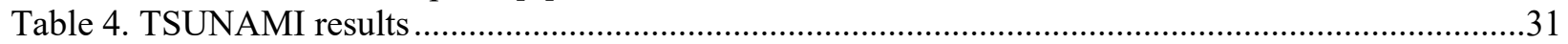

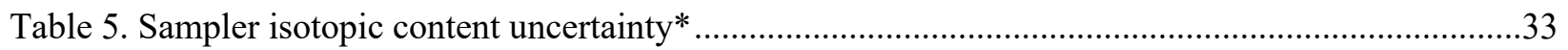

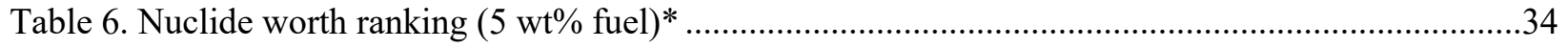

Table 7. Layout of tables for isotopic composition comparisons .............................................................35

Table 8. Contributions of each isotope to total percent change in decay heat ............................................40

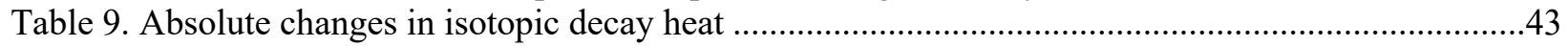

Table 10. Differences in isotopic activity differences shown as a percentage of the total activity .............46

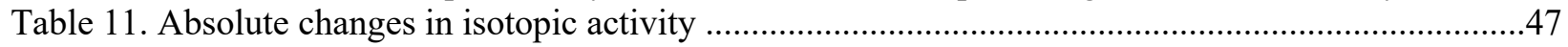

Table 12. Change in activity of selected "accident release" isotopes .....................................................49

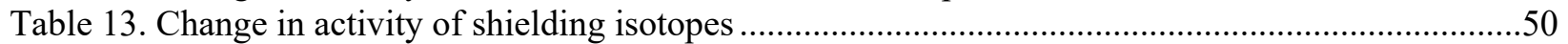

Table 14. Relative difference in SF neutron emission on total SF neutron emission basis for time

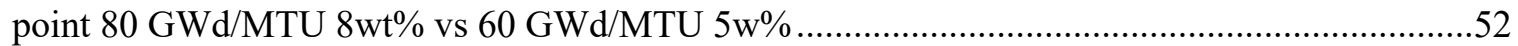

Table 15. Relative mass difference for criticality isotopes as ppm of total $\mathrm{UO}_{2}$ mass for separate

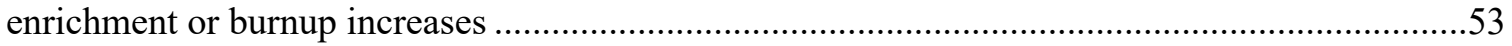

Table 16. Mass difference for criticality isotopes as ppm of total $\mathrm{UO}_{2}$ mass for simultaneously

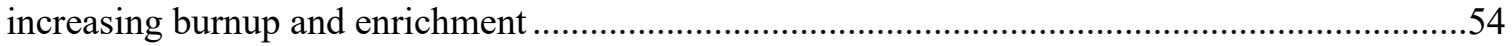

Table 17. Relative mass difference for criticality isotopes on isotope basis at time point .........................55

Table 18. Relative mass difference for criticality isotopes on isotope mass basis at time point ................56

Table 19. Change in isotopics due to cross section library 252- vs 56-group ........................................58

Table A.1. Fractional contributions of istopes to total activity of $60 \mathrm{GWd} / \mathrm{MTU} 5 \mathrm{wt} \%$ case ............... A-1

Table A.2. Fractional contributions of istopes to total activity of $60 \mathrm{GWd} / \mathrm{MTU} 8 \mathrm{wt} \%$..................... A-4

Table A.3. Fractional contributions of istopes to total activity of $80 \mathrm{GWd} / \mathrm{MTU} 6.5 \mathrm{wt} \%$................. A-6

Table A.4. Fractional contributions of istopes to total activity of $80 \mathrm{GWd} / \mathrm{MTU} 8 \mathrm{wt} \%$.................... A-10

Table C.1. Section 3.1 Spreadsheets and computer code runs...........................................................

Table C.2. Section 3.2 Spreadsheets and computer code runs............................................................

Table C.3. Section 3.3 Spreadsheets and computer code runs............................................................

Table C.4. Section 3.4 Spreadsheets and computer code runs..............................................................

Table C.5. Section 3.5 Spreadsheets and computer code runs..........................................................

Table C.6. Section 3.6 Spreadsheets and computer code runs...........................................................2

Table C.7. Section 4.1 Spreadsheets and computer code runs..............................................................

Table C.8. Section 4.2 Spreadsheets and computer code runs..............................................................

Table C.9. Section 4.3 Spreadsheets and computer code runs........................................................

Table C.10. Section 5 Spreadsheets and computer code runs.................................................................. 


\section{ACRONYMS AND ABBREVIATIONS}

ATF

BOC

BW

CRW

DTC

EE

ENDF

EOC

GWd/MTU

HALEU

HFP

IAEA

IFBA

JEFF

LWR

MTC

PWR

RMS

SFP

$\mathrm{S} / \mathrm{U}$ accident-tolerant fuel

beginning of cycle

[soluble] boron worth

control rod worth

Doppler temperature coefficient

extended enrichment

Evaluated Nuclear Data File

end of cycle

gigawatt-days per metric ton of uranium

high assay low-enriched uranium

hot full power

International Atomic Energy Agency

integral fuel burnable absorber

Joint Evaluated Fission and Fusion File

light water reactor

moderator temperature coefficient

pressurized water reactor

root mean square

spent fuel pool

sensitivity and uncertainty 


\section{SUMMARY}

Commercial light water reactor (LWR) operators and fuel vendors in the United States are pursuing changes to nuclear fuel that include extended enrichment (EE) and accident-tolerant fuel (ATF) designs. The term $E E\left(8 \%>{ }^{235} \mathrm{U}>5 \%\right)$ is used in this report to refer to a subset of high assay low-enriched uranium (HALEU) that is considered usable in commercial US LWRs in the near term. ATF features are designed to improve fuel system performance under accident conditions. One goal of EE is to improve fuel cycle economy by enabling fuel to be depleted to higher burnup than the typical current maximum pin burnup limits (62 gigawatt-days per metric ton of uranium [GWd/MTU]). Adoption of EE, ATF, and high burnup (HBU) fuels in the US commercial fleet requires a clear understanding of the effects on core physics parameters and used fuel isotopic content, as well as confidence in the accuracy of computer code predictions over an expanded range of materials, enrichment, and burnup. A thorough understanding of the applicability and adequacy of benchmark data (e.g., criticality, decay heat, isotopic content) for computer code validation is necessary to ensure that appropriate safety margins are maintained.

To prepare for and support these potential changes, the effects of EE, ATF, and HBU are being assessed for selected representative LWR fuel designs. The project is divided into phases: this report summarizes the findings of Phase 1, which focuses on the lattice physics parameter and used fuel isotopic changes for a conventional Westinghouse $17 \times 17$ pressurized water reactor $(\mathrm{PWR})$ design. The primary investigation tool is the SCALE Polaris code using the SCALE 56-group Evaluated Nuclear Data File (ENDF)/B-VII.1 cross sections.

The goal of the current work is to (1) identify and explain important effects of EE and HBU (reactivity, lattice physics, and isotopic effects) assuming that PWR fuel design and usage remain similar to those for current enrichment fuel, (2) provide limited code-to-code comparisons with higher order cross section libraries and/or codes, and (3) identify any apparent anomalous trends in the results for further investigation.

This activity is part of Phase 1 of HALEU/HBU/ATF SCALE code preparedness activities beginning in Q2 FY20 and ending in Q2 FY21. This report addresses the following NRC user needs within the Nuclear Reactor Regulation (NRR) and Nuclear Material Safety and Safeguards offices.

- Identify data needs for high burnup and enrichment $>5 \%$ in SCALE.

- Compare isotopics from baseline ( $\sim 62 \mathrm{GWD} / \mathrm{MTU}$ rod average) to $75 \mathrm{GWD} / \mathrm{MTU}$ rod-average and quantify impact on reactivity, decay heat, and radioactive source terms in prototypical applications in each area.

- Compare isotopics from baseline (5\%) to $8 \%$, and quantify impact on reactivity, decay heat, and radioactive source terms in prototypical applications in each area.

These NRC user needs are expected to change and adapt to the ever-changing commercial nuclear landscape. Phase 2 HALEU/HBU/ATF SCALE activities are expected to focus on core level (PARCS) assessments as well as code development efforts recommended by Phase 1 activities. If new user needs are available, activities identified for Phase 2 will be re-mapped and re-prioritized according to the updated user needs.

Calculations were performed using a pre-release version of SCALE 6.3 Polaris, TSUNAMI, and ORIGEN computer codes to evaluate the effects of EE and HBU fuels on depletion characteristics of a representative commercial PWR fuel assembly (Westinghouse $17 \times 17$ with 104 integral fuel burnable absorber [IFBA] rods). The investigation focused on differences between depletions of well-understood LWR fuel ( $5 \mathrm{wt} \%{ }^{235} \mathrm{U}$ depleted to $\left.60 \mathrm{GWd} / \mathrm{MTU}\right)$ and depletion for enrichments up to $8 \mathrm{wt} \%$ and burnup up to $80 \mathrm{GWd} / \mathrm{MTU}$. 
Key quantities of interest include (1) lattice physics parameters (reactivity, reactivity coefficients, power and distributions, cross sections, and kinetics parameters), (2) isotopic inventory at various decay times, (3) neutronic similarity in spent fuel pool (SFP) storage, and (4) uncertainty in $\mathrm{k}_{\text {inf }}$ arising directly from cross section uncertainties and indirectly from uncertainties in the discharged isotopic content. Limited comparisons between predictions using SCALE 56-group ENDF/B-VII.1 cross sections and SCALE 252group ENDF/B-VII.1 cross sections are also presented.

No unexpected or anomalous trends were found that would call into question the accuracy of the Polaris code using SCALE 56-group ENDF/B-VII.1 cross sections for depletion, lattice physics, and isotopic content calculations of the analyzed PWR fuel with enrichments up to $8 \mathrm{wt} \%$ and burnup up to $80 \mathrm{GWd} / \mathrm{MTU}$. For multiple physical quantities of interest, increases in enrichment and increases in burnup had opposing and offsetting effects. Finally, a limited neutronic similarity comparison of PWR fuel assemblies in SFP storage with 3 different enrichment and burnup combinations ( $5 \mathrm{wt} \% 60$ $\mathrm{GWd} / \mathrm{MTU}, 8 \mathrm{wt} \% 84 \mathrm{GWd} / \mathrm{MTU}$, and $8 \mathrm{wt} \% 94 \mathrm{GWd} / \mathrm{MTU})$ suggests that validation of the SFP burnup credit criticality code should not be strongly impacted by HALEU/HBU. 


\section{INTRODUCTION}

Commercial light water reactor (LWR) operators and fuel vendors in the United States are pursuing evolutionary changes to nuclear fuel that include updated extended enrichment (EE) fuel $\left({ }^{235} \mathrm{U}\right.$ enrichment within 5-8wt\%) and accident-tolerant fuel (ATF) designs intended to improve fuel and cladding performance under accident conditions $[1,2]$. One goal of this effort is to improve fuel cycle economy by enabling fuel to be depleted to higher burnup than presently possible. Adoption of these changes in the US commercial fleet requires a clear understanding of the effects on core physics parameters and used fuel isotopic content, as well as confidence in the accuracy of computer code predictions over an expanded range of materials, enrichment, and burnup. A thorough understanding of the applicability and adequacy of benchmark data (e.g., criticality, decay heat, isotopic content) for computer code validation is necessary to ensure that appropriate safety margins are maintained.

To prepare for and support these potential changes, the effects of EE, ATF, and high burnup (HBU) fuels are being assessed for selected representative LWR fuel designs. This Volume I report focuses on changes to lattice physics parameters and used fuel isotopic compositions for a conventional Westinghouse $17 \times 17$ pressurized water reactor (PWR) design [3]. The SCALE Polaris lattice physics code and the ORIGEN depletion and decay code are the primary investigation tools [4].

To aid in understanding the best-estimate effects of $\mathrm{EE}$ and $\mathrm{HBU}$, various quantities of interest for $\mathrm{UO}_{2}$ fuel ${ }^{235} \mathrm{U}$ enrichments are evaluated at 5, 6.5, and $8 \mathrm{wt} \%$ up to $80 \mathrm{GWd} / \mathrm{MTU}$ lattice-average burnup, with a focus on differences relative to $5 \mathrm{wt} \%$ enrichment up to $60 \mathrm{GWd} / \mathrm{MTU}$.

Power was not varied in this study because it is implicitly included in burnup. Furthermore, power is not expected to change with EE and HBU due to its being set by thermal hydraulic limits. Therefore power is not a parameter being varied in this study.

The quantities of interest include:

- Lattice physics behavior (modeled with Polaris)

$\circ$ Neutron flux and flux spectrum

$\circ \quad$ Reactivity ( $\mathrm{k}_{\text {inf }}$, reactivity coefficients)

- Power factors (pin power peaking, radial pellet peaking)

- Burnup distribution (minimum and maximum pin burnup, radial pellet burnup distribution)

$\circ$ Nodal data (2-group macroscopic cross sections)

- Trends and contributing isotopic inventory of importance in four categories

○ Decay heat (short- and long-term decay times)

- Shielding (activity at short- and long-term decay times)

- Severe accident (important nuclides at short and long decay times)

$\circ$ Criticality (during decay)

These calculations are 2D, representing assembly average quantities and equilibrium cycles. $5 \mathrm{wt} \%$ is the current enrichment limit for commercial LWRs, $8 \mathrm{wt} \%$ bounds the maximum envisioned near-term enrichment increase, and $6.5 \mathrm{wt} \%$ is included as a midpoint to improve confidence in observed trends. Evaluation of 3D parameters such as axial burnup shapes will be performed in later work.

The uncertainty of EE and HBU models relative to conventional fuel models is also of interest. Preliminary results of limited sensitivity and uncertainty $(\mathrm{S} / \mathrm{U})$ analyses are presented, comparing fuel assemblies of differing enrichment and burnup in spent fuel storage. The primary tools for $\mathrm{S} / \mathrm{U}$ analysis are TSUNAMI-3D [5] and Sampler/Polaris [4]. These analyses quantify uncertainty in $\mathrm{k}_{\text {inf }}$ and in depleted 
fuel isotopic content due to nuclear data uncertainty using the cross section covariance data included in SCALE. TSUNAMI-IP [5] is also used to calculate a similarity coefficient representing the neutronic similarity of a $5 \mathrm{wt} \% 60 \mathrm{GWd} / \mathrm{MTU}$ fuel assembly, an $8 \mathrm{wt} \% 84 \mathrm{GWd} / \mathrm{MTU}$ fuel assembly, and an 8 wt\% $94 \mathrm{GWd} / \mathrm{MTU}$ fuel assembly stored in a simplified spent fuel pool (SFP) rack cell [6]. The following preliminary $\mathrm{S} / \mathrm{U}$ data are presented.

- Sampler/Polaris pincell $\mathrm{k}_{\text {inf }}$ uncertainty (perturbed cross sections at in-reactor hot full power (HFP) conditions) for $5 \mathrm{wt} \%$ fuel depleted to 60 and $80 \mathrm{GWD} / \mathrm{MTU}$

- Sampler/Polaris pincell perturbed cross section depletions (isotopic content and $\mathrm{k}_{\text {inf }}$ uncertainty at inreactor HFP conditions) for $5 \mathrm{wt} \%$ fuel depleted to 60 and $80 \mathrm{GWD} / \mathrm{MTU}$ isotope worth ranking by importance to $\mathrm{k}_{\text {inf }}$ (in-reactor HFP conditions) for $5 \mathrm{wt} \%$ fuel depleted to 60 and $80 \mathrm{GWD} / \mathrm{MTU}$

- TSUNAMI-IP in-rack similarity coefficient $\left(\mathrm{c}_{\mathrm{k}}\right)$ for three different combinations of enrichment and burnup

- $\quad$ TSUNAMI-3D in-rack $\mathrm{k}_{\text {inf }}$ uncertainty due to cross section uncertainty for three different combinations of enrichment and burnup

Polaris models are described in Section 2. Lattice physics comparisons are presented in Section 3. Section 4 describes and summarizes the preliminary $\mathrm{S} / \mathrm{U}$ analysis. Isotopic inventory comparisons are presented in Section 5 .

\subsection{EXPECTED EFFECTS OF HBU AND EE ON FUEL MANAGEMENT}

This evaluation of EE and HBU fuel is focused on existing commercial PWRs. The significance of lattice physics trends is better understood if viewed through the lens of the practical PWR fuel management changes that are likely to result from using increased enrichment fuel. The driving force for use of higher enrichment fuel is to achieve reduced fuel cycle costs through increased fuel discharge burnup. As is consistent with prior experience, increased enrichment results in increased burnup, and the effects should be evaluated in combination.

There are at least two ways that EE may affect fuel cycle management. First, cycle length could be maintained, and the size of the reload fuel batch could be reduced. This approach would result in higher core average burnup throughout a cycle and higher discharge fuel assembly burnup. It is also possible that increased enrichment could be used to increase cycle length (perhaps from 18 to 24 months). This strategy would increase end-of-cycle (EOC) core average burnup and discharge burnup. The net effect on beginning of cycle (BOC) core average burnup would depend in part on batch size. From a fuel cycle management perspective, EE and HBU are expected to be positively correlated for at least part of a reload cycle.

One problem in achieving a longer cycle with $\mathrm{EE}$ is that increased excess reactivity at BOC requires more reactivity hold-down (burnable absorbers and/or soluble boron). As shown in the lattice physics results, EE reduces boron worth (BW) substantially, making it more difficult to load sufficient neutron absorbers to satisfy BOC hold-down requirements.

Regardless of whether increased enrichment is used to achieve smaller batch sizes or longer cycles, higher core average burnup during at least part of a cycle and higher assembly discharge burnup are expected to result. A first-order approximation of the increase in mid-to-late-cycle core average burnup expected from an increase in enrichment was developed and is presented in Section 3.2 (Figure 6). This 
approximation uses results from lattice physics calculations to enhance understanding of some of the expected core average effects of EE and HBU in combination.

\section{POLARIS MODEL DESCRIPTION}

A Westinghouse $17 \times 17$ PWR fuel assembly was used as a representative design for the Phase 1 Polaris model lattice physics analysis. Table 1 provides details of the fuel assembly design and the Polaris model data. To obtain results representative of current generation fuel management, the model included a $5 \mathrm{wt} \%$ reference assembly containing 104 integral fuel burnable absorber (IFBA) rods and was depleted with $1,000 \mathrm{ppm}$ soluble boron at nominal power and temperatures.

The cycle average boron was based on a recent license amendment request that shows cycle average soluble boron ranging from 815 to 1,051 ppm for a 3-loop PWR with a maximum licensed fuel enrichment of $4.6 \mathrm{wt} \%{ }^{235} \mathrm{U}$. [5] The IFBA rod pattern was the same as that presented in NUREG/CR6760 [3, Figure 6]. Figure 1 shows the pin layout of the model.

Table 1. Fuel design and Polaris model data

\begin{tabular}{lc}
\hline Parameter & \multicolumn{1}{c}{ Value } \\
\hline Assembly lattice & $21.5 \mathrm{~cm}$ \\
\hline Assembly pitch & 264 \\
\hline Fuel rods & 104 \\
\hline IFBA rods & 24 \\
\hline Guide tubes & 1 \\
\hline Instrument tubes & $1.26 \mathrm{~cm}$ \\
\hline Fuel rod pitch & Zirc-4 \\
\hline Clad material & $0.4096 \mathrm{~cm}$ \\
\hline $\mathrm{UO}_{2}$ pellet radius & $3 \mathrm{equal} \mathrm{volume}$ \\
\hline $\mathrm{UO}_{2}$ model depletion rings & $10.26 \mathrm{~g} / \mathrm{cm}$ \\
\hline $\mathrm{UO}_{2}$ effective density & $0.4106 \mathrm{~cm}$ \\
\hline IFBA radius & $0.927 \mathrm{mg} / \mathrm{cm} / \mathrm{rod}$ \\
\hline IFBA B-10 loading & $0.418 \mathrm{~cm}$ \\
\hline Clad inner radius & $0.475 \mathrm{~cm}$ \\
\hline Clad outer radius & $0.561 \mathrm{~cm}$ \\
\hline Guide tube inner radius & $0.602 \mathrm{~cm}$ \\
\hline Guide tube outer radius & $0.559 \mathrm{~cm}$ \\
\hline Instrument tube inner radius & $0.605 \mathrm{~cm}$ \\
\hline Instrument tube outer radius & $0.01 \mathrm{~cm}$ \\
\hline Polaris ray spacing & $900 \mathrm{~K}$ \\
\hline Fuel temperature & $583.15 \mathrm{~K}$ \\
\hline Coolant temperature & $0.7048 \mathrm{~g} / \mathrm{cm}$ \\
\hline Coolant density & $700 \mathrm{~K}$ \\
\hline Clad temperature & $40 \mathrm{MW} / \mathrm{MTU}$ \\
\hline Depletion power & \\
\hline
\end{tabular}


Polaris depletions were performed for 5 (baseline), 6.5, and $8 \mathrm{wt} \%{ }^{235} \mathrm{U}$ fuel assemblies from 0 to 80 $\mathrm{GWd} / \mathrm{MTU}$. Depletion steps to 0.1 and $11 \mathrm{GWd} / \mathrm{MTU}$ were followed by $2 \mathrm{GWd} / \mathrm{MTU}$ steps to 20 $\mathrm{GWd} / \mathrm{MTU}$, $2.5 \mathrm{GWd} / \mathrm{MTU}$ steps to $40 \mathrm{GWd} / \mathrm{MTU}$, and $4 \mathrm{GWd} / \mathrm{MTU}$ steps to $80 \mathrm{GWd} / \mathrm{MTU}$. Appendix $\mathrm{B}$ provides a comparison of Polaris $\mathrm{k}_{\text {inf }}$ results using the selected depletion steps to two additional depletions with smaller steps. Fuel pellets in each fuel pin were modeled with three equal volume radial regions (rings) to provide information on power and burnup distribution within each pin. No design changes to conventional fuel pellets were assumed.

The increased enrichment models were depleted twice, once with 1,000 ppm soluble boron, and a second time with the soluble boron increased to provide the same total BW as the $5 \mathrm{wt} \%$ model. Soluble BW decreased with increasing fuel enrichment. The increased boron in the second depletion approximated the expected cycle average boron increase required for criticality in an equilibrium cycle with increased enrichment fuel. The lattice physics parameter comparisons use the increased boron depletion results, but the isotopic comparisons do not.

Two SCALE cross section libraries are available for use with Polaris: 56- and 252-group ENDF/B-VII.1. Lattice physics parameters and fuel depletion isotopic content were calculated using the 56-group library. Some 252- and 56-group library depletion $\mathrm{k}$ and reactivity coefficient comparisons are also provided to help determine whether EE and HBU introduce challenges for the 56-group library.

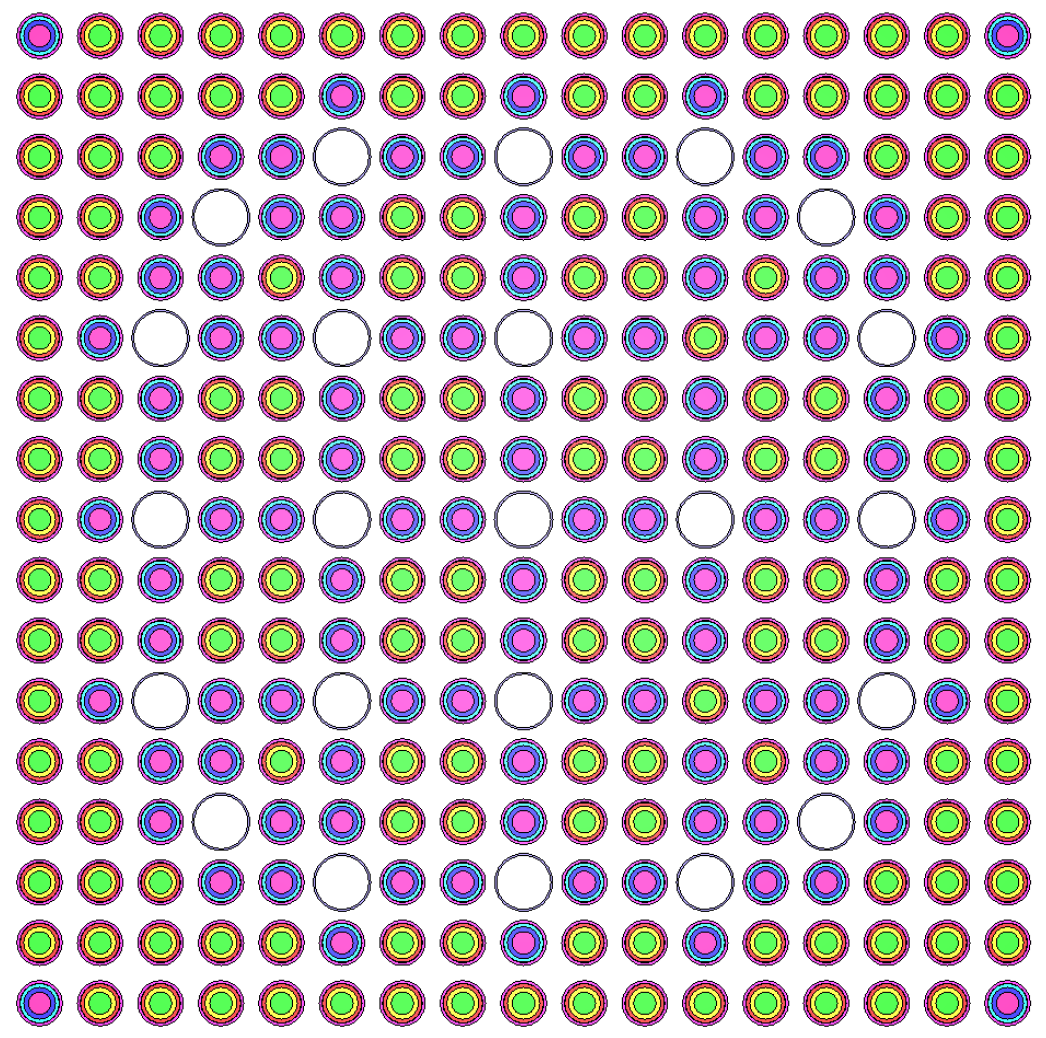

Figure 1. Westinghouse 17×17 104 IFBA model (three radial rings per fuel pellet). 


\section{LATTICE PHYSICS RESULTS}

\subsection{FLUXES AND FLUX SPECTRUM}

Many EE and HBU lattice physics effects are readily explained by changes in the neutron flux magnitude and the neutron energy spectrum. Flux changes are largely a function of the amount of fissile nuclides with large thermal absorption cross sections $\left({ }^{235} \mathrm{U},{ }^{239} \mathrm{Pu}\right.$ amd $\left.{ }^{241} \mathrm{Pu}\right)$. Increased fissile content absorption hardens the neutron energy spectrum and reduces the flux (particularly thermal flux) needed to sustain a particular fission rate and power level.

Figure $2 \mathrm{a}$ and Figure $2 \mathrm{~b}$ show that the fissile content for an $8 \mathrm{wt} \%{ }^{235} \mathrm{U}$ fuel assembly is much higher than for a $5 \mathrm{wt} \%{ }^{235} \mathrm{U}$ throughout the depletion range. Total fissile content for the $8 \mathrm{wt} \%$ assembly at 80 $\mathrm{GWd} / \mathrm{MTU}$ burnup is roughly equivalent to the $5 \mathrm{wt} \%$ assembly at $40 \mathrm{GWd} / \mathrm{MTU}$. For a given burnup, the $\mathrm{Pu}$ fraction of total fissile content is much lower in the $8 \mathrm{wt} \%$ lattice than in the $5 \mathrm{wt} \%$ lattice.

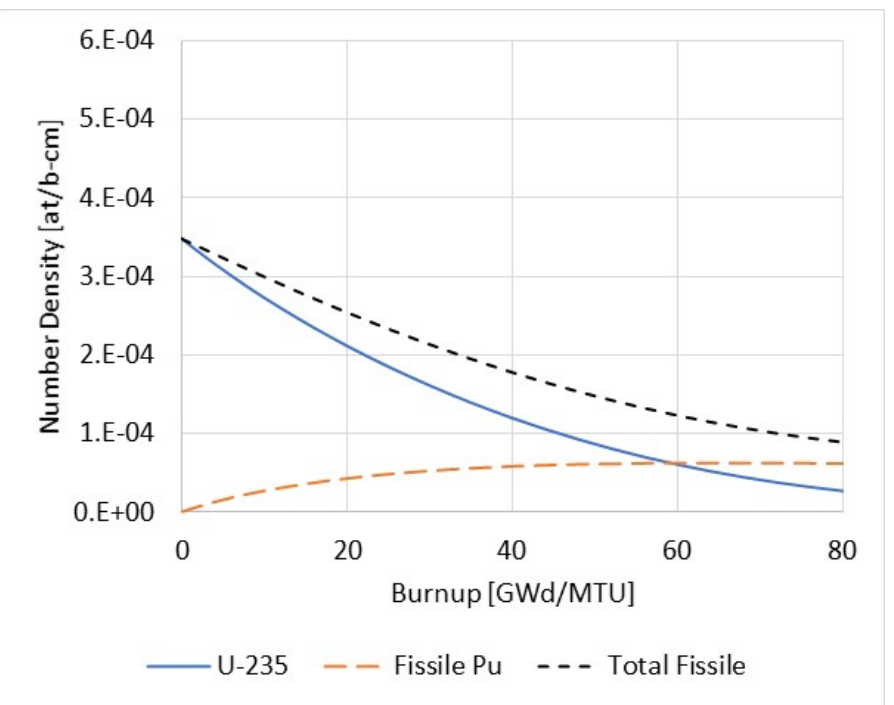

Figure 2a. Depletion fissile content for $5 \mathrm{wt} \%{ }^{235} \mathrm{U}$.

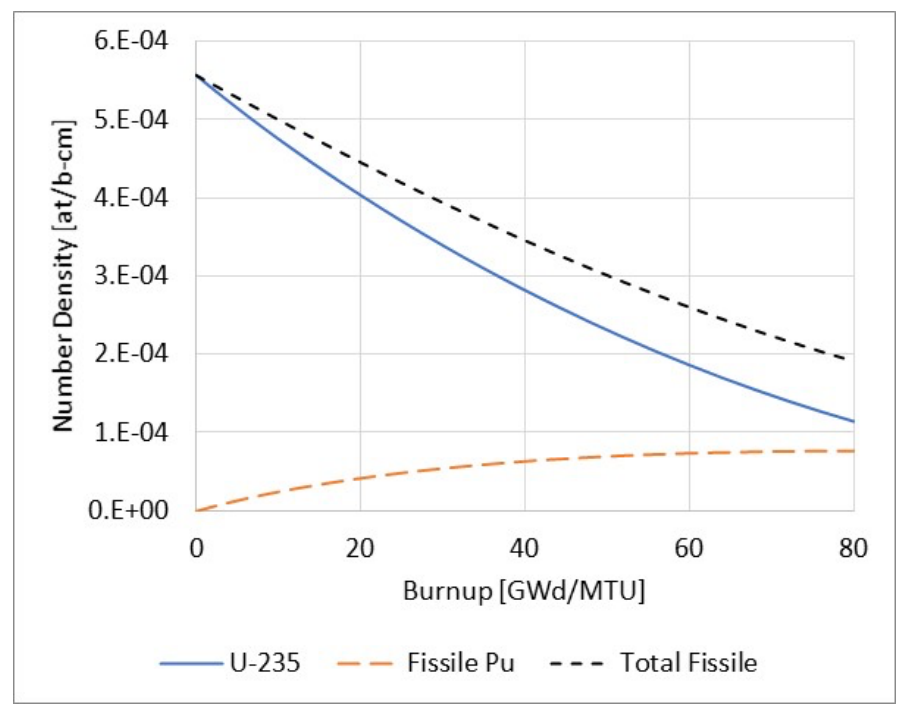

Figure 2b. Depletion fissile content for $8 \mathrm{wt} \%{ }^{235} \mathrm{U}$. 
Figure 3 shows the fast/thermal flux ratio for both depletions and demonstrates the magnitude of spectrum hardening due to increased enrichment. Total flux is shown in Figure 4 using pellet-clad gap flux as representative of the lattice. Total flux reduction ranges from 10 to $15 \%$ over the burnup range. In particular, spectral hardening and flux reduction can reduce the worth of absorbers, cause slower depletion of burnable absorbers, and reduce the reactivity magnitude of ${ }^{135} \mathrm{Xe}$ transients.

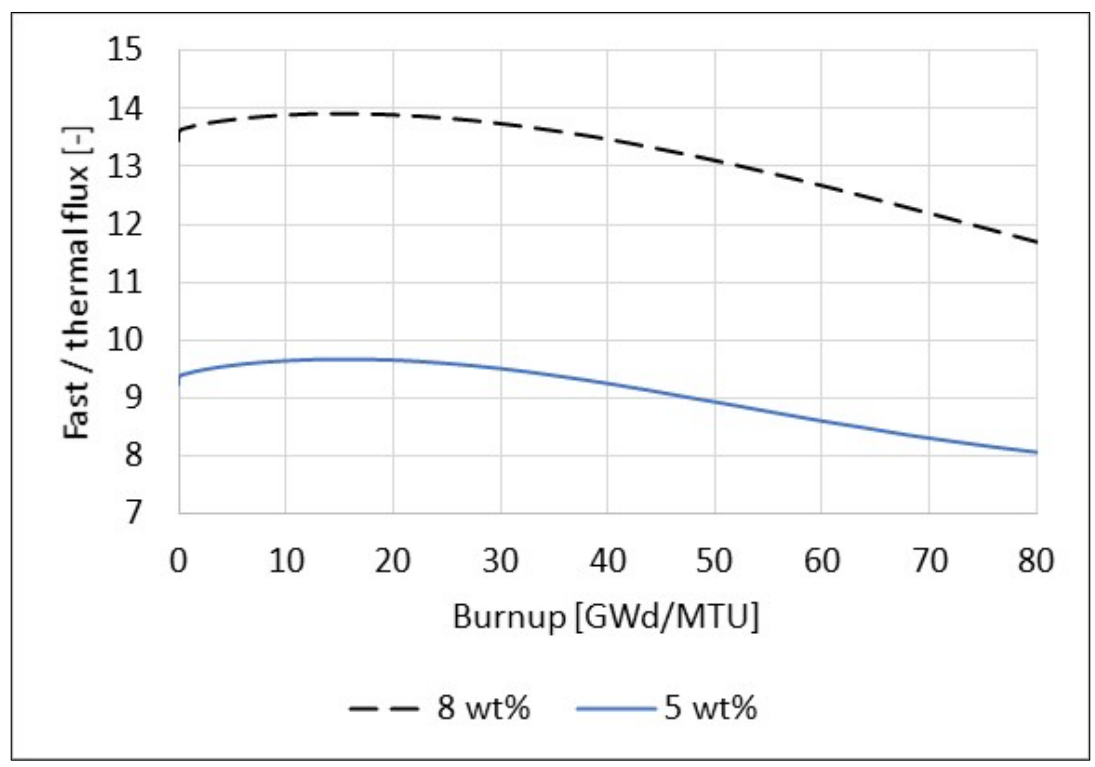

Figure 3. Fast / thermal flux ratio.

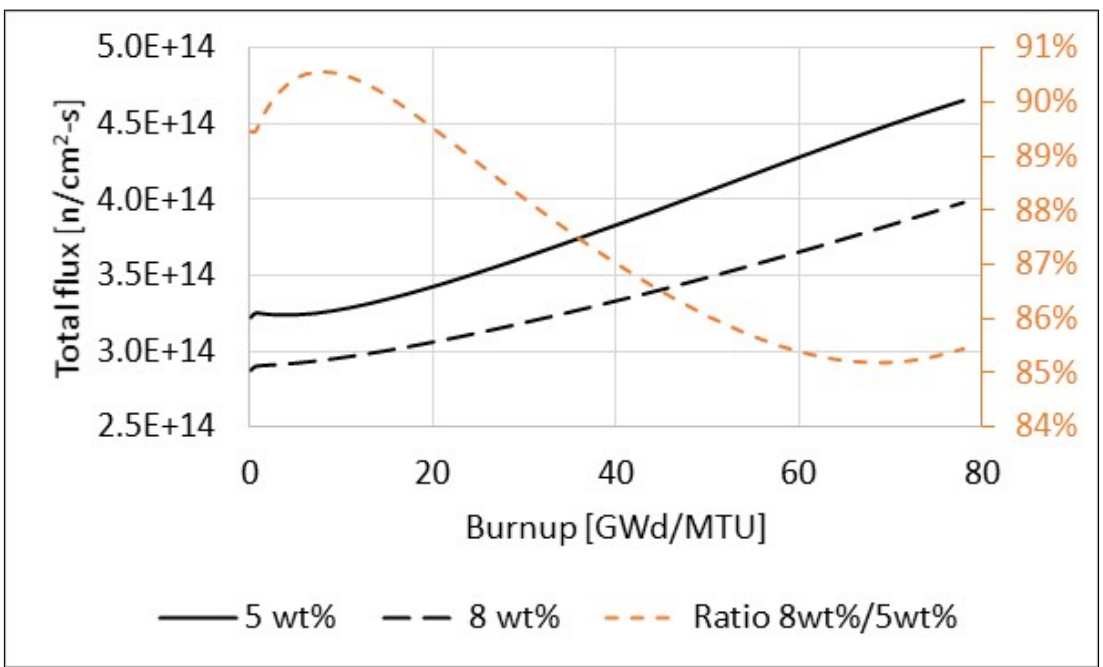

Figure 4. Total flux. 


\subsection{REACTIVITY AND COEFFICIENTS}

Reactivity comparisons for EE/HBU depletions presented herein include HFP depletion $\mathrm{k}_{\text {inf, as well as }}$ reactivity coefficients and control rod worth (CRW). Coefficients and worths were calculated for each depletion step using the Polaris depletion $\mathrm{k}_{\text {inf }}$ as the nominal condition. Branch cases were performed with a fuel temperature of $950 \mathrm{~K}$ fuel temperature, $0 \mathrm{ppm}$ soluble boron, and a coolant temperature of 588.15 $\mathrm{K}\left(0.6929 \mathrm{~g} / \mathrm{cm}^{3}\right.$ coolant density), with control rods inserted.

Results are presented graphically in this section, with discussion notes accompanying each figure. Reactivity coefficients are abbreviated as DTC (Doppler temperature coefficient), MTC (moderator temperature coefficient), and $B W$ ([soluble] boron worth).

As illustrated in Figure 5, reactivity increases with increasing enrichment due to the increase in fissile content. The increase in $\mathrm{k}_{\text {inf }}$ between 0 and $10 \mathrm{GWd} / \mathrm{MTU}$ is due to burnable poison (IFBA) initially depleted faster than fissile material. IFBA neutron absorption is lower and IFBA depletion is slower with higher fuel enrichment (harder energy spectrum). The IFBA burnout peak is less pronounced as fuel enrichment increases. Reducing IFBA worth and burnout rate reduces the portion of the depletion during which IFBA depletion is greater than fuel depletion (positive $\mathrm{k}_{\text {inf }}$ slope), which in turn shifts the $\mathrm{k}_{\text {inf }}$ peak toward lower burnup. It is likely that higher enrichments will require more burnable absorber (IFBA rods, gadolinia, removable burnable poison rod assemblies, or a combination thereof) that would change the curve shapes. A constant number of IFBA rods was used in these comparisons to illustrate the effect of increased enrichment apart from other changes.

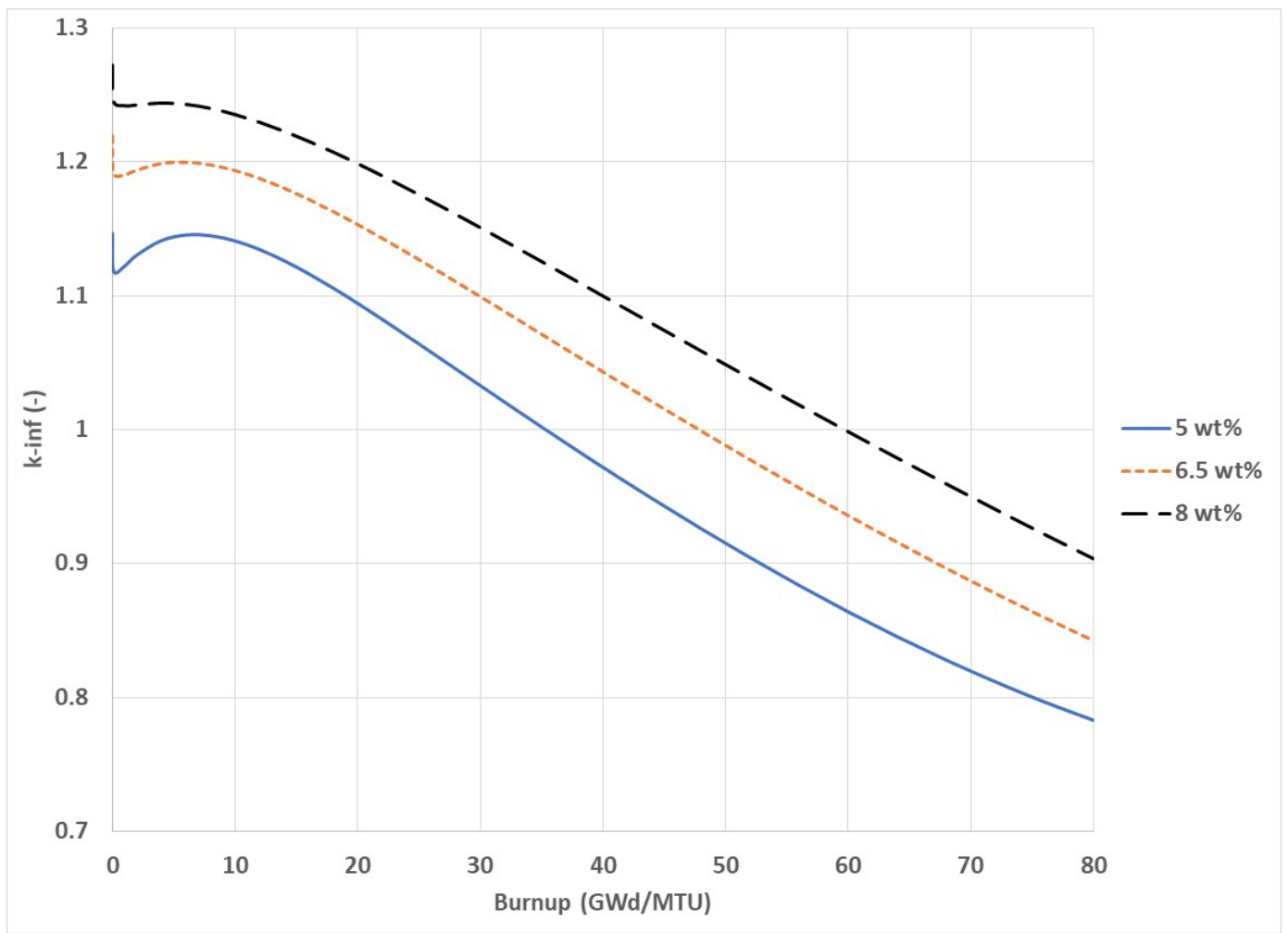

Figure 5. HFP depletion $k_{\text {inf }}(1,000 \mathrm{ppm}$ soluble boron).

As can be seen in Figure 6, the increase in $\mathrm{k}_{\text {inf }}$ that results from increased enrichment shows the effect of slower IFBA burnout. The slower burnout increases the amount of IFBA remaining in higher enrichment 
fuel relative to lower enrichment fuel until about $10 \mathrm{GWd} / \mathrm{MTU}$. Except for IFBA effects, $\Delta \mathrm{k}$ is relatively constant.

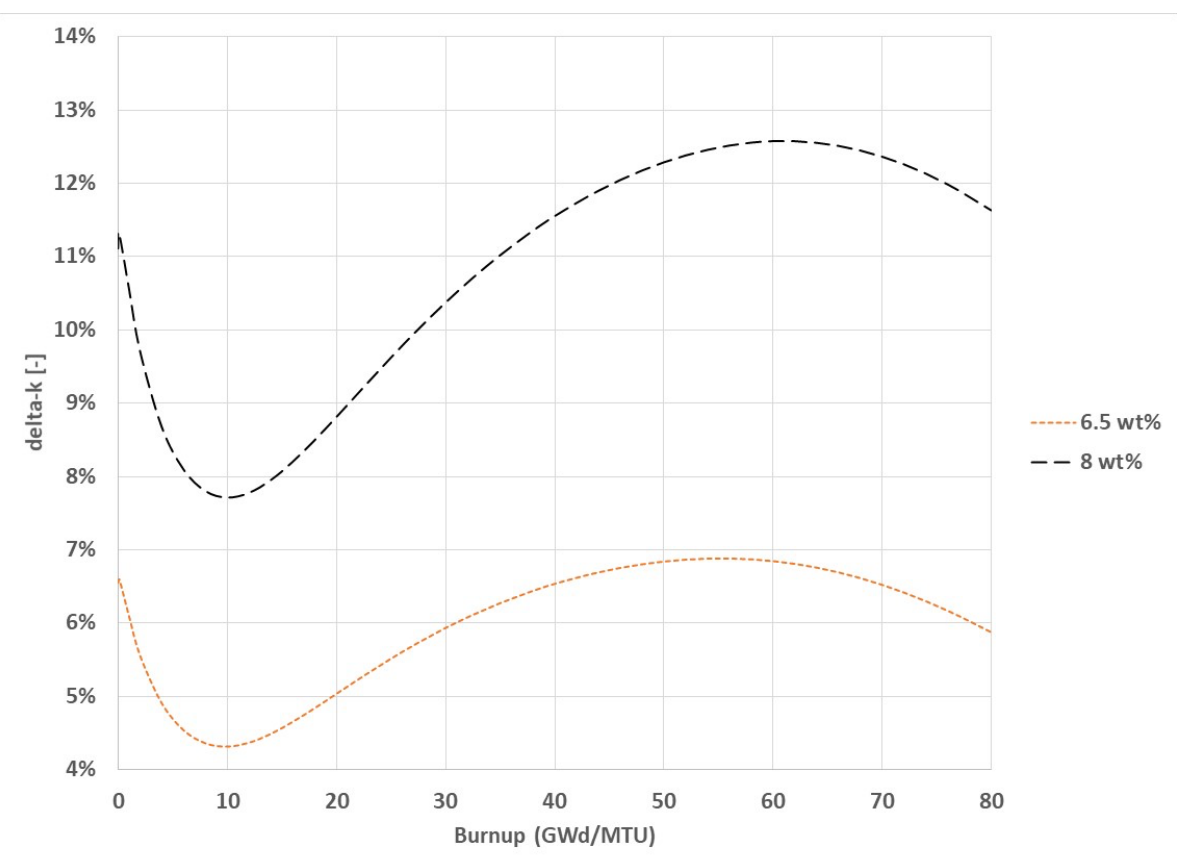

Figure 6. HFP depletion $\Delta \mathrm{k}$ relative to $5 \mathrm{wt} \%(0 \mathrm{ppm}$ soluble boron $)$.

As shown in Figure 7, boron worth declines with increasing enrichment. The amount of boron needed for reactivity control will increase due to reduced worth and increased fuel reactivity. Additional burnable absorbers may also be used to offset increased fuel reactivity.

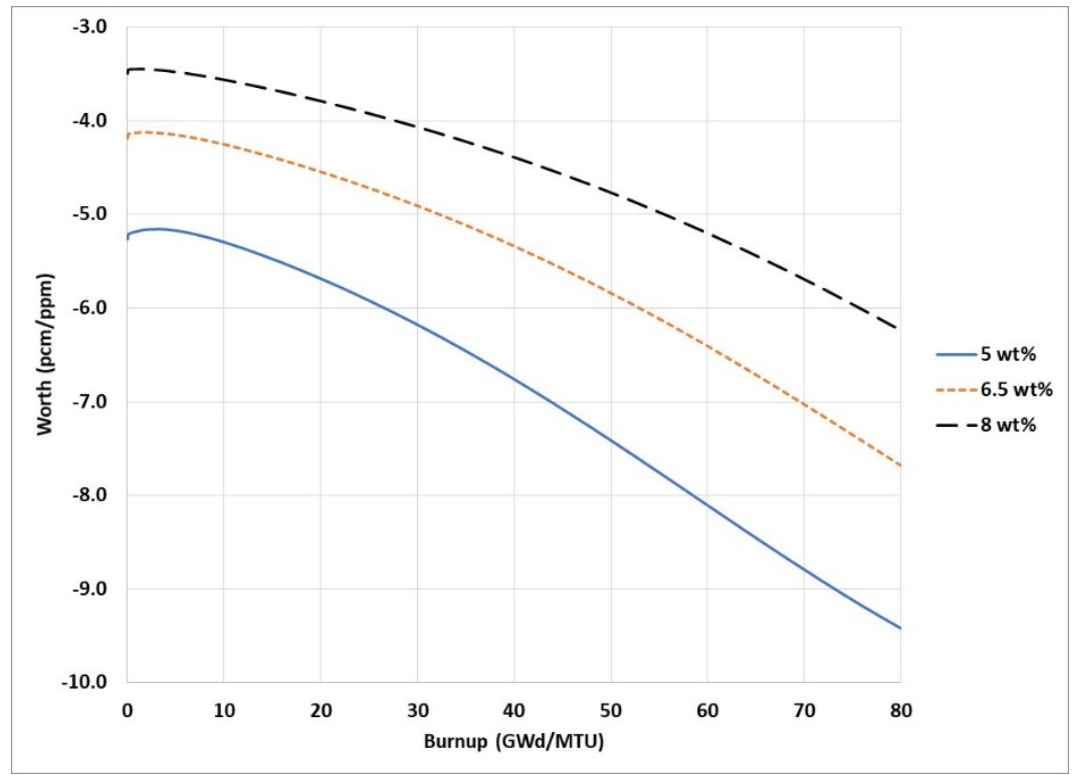

Figure 7. HFP soluble boron worth. 
Figure 8 shows the amount of soluble boron needed to provide the same total BW as $1,000 \mathrm{ppm}$ in the 5 $\mathrm{wt} \%$ assembly depletion. Equivalent boron was averaged over burnup and used in a second set of depletions to approximate the expected cycle average soluble boron depletion conditions for higher enrichment fuel $(1,250 \mathrm{ppm}$ for $6.5 \mathrm{wt} \%, 1,520 \mathrm{ppm}$ for $8 \mathrm{wt} \%)$.

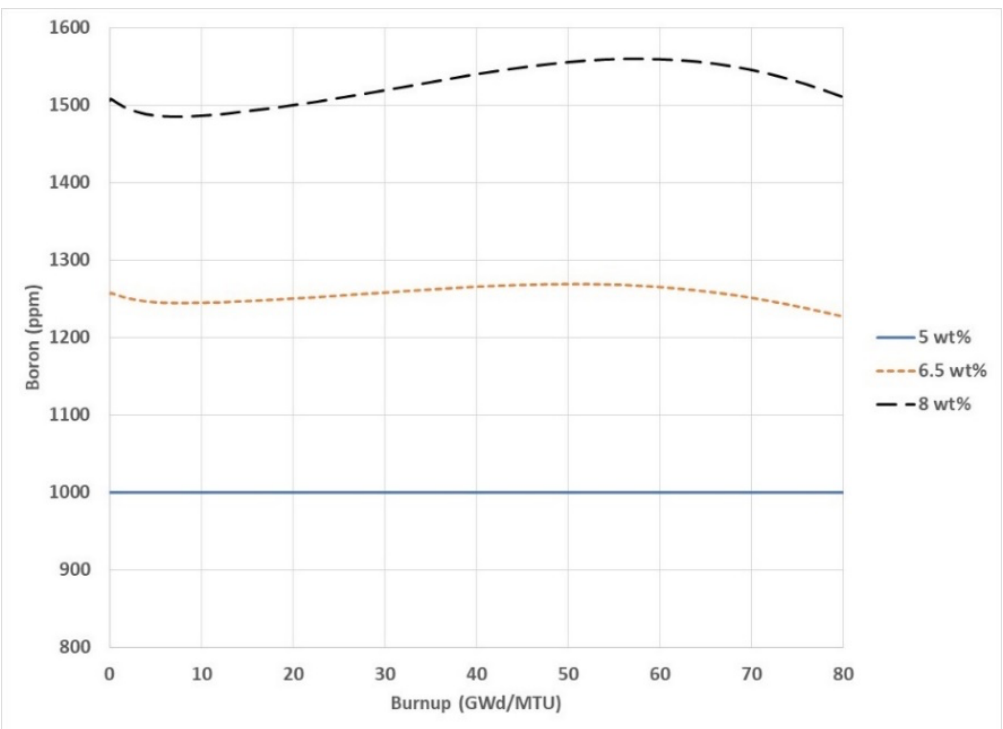

Figure 8. HFP equivalent depletion boron.

The Figure 9 plot of $\mathrm{k}_{\text {inf }}$ with no soluble boron gives an estimate of the cycle average burnup increase expected to result from using higher enrichment fuel. Core average $\mathrm{k}_{\text {inf }}$ at EOC in PWR core models is approximately $1.04(\sim 4 \% \Delta \mathrm{k}$ leakage) with no soluble boron. Assuming equilibrium cycles, the cycle average burnup increase is approximately $11 \mathrm{GWd} / \mathrm{MTU}$ for each $1.5 \mathrm{wt} \%$ increase in enrichment based on the intersection of each curve with the $1.04 \mathrm{k}_{\text {inf }}$ line. Although actual cores contain two or more batches of fuel with different burnups (some depleted for one cycle, some for two cycles, etc.), a single assembly model can be thought of as a first-order approximation of the effective (batch importance weighted) core average. The estimated EOC burnup change with enrichment can be used with other lattice physics data (e.g., reactivity coefficients) to estimate core average effects when core models are unavailable.

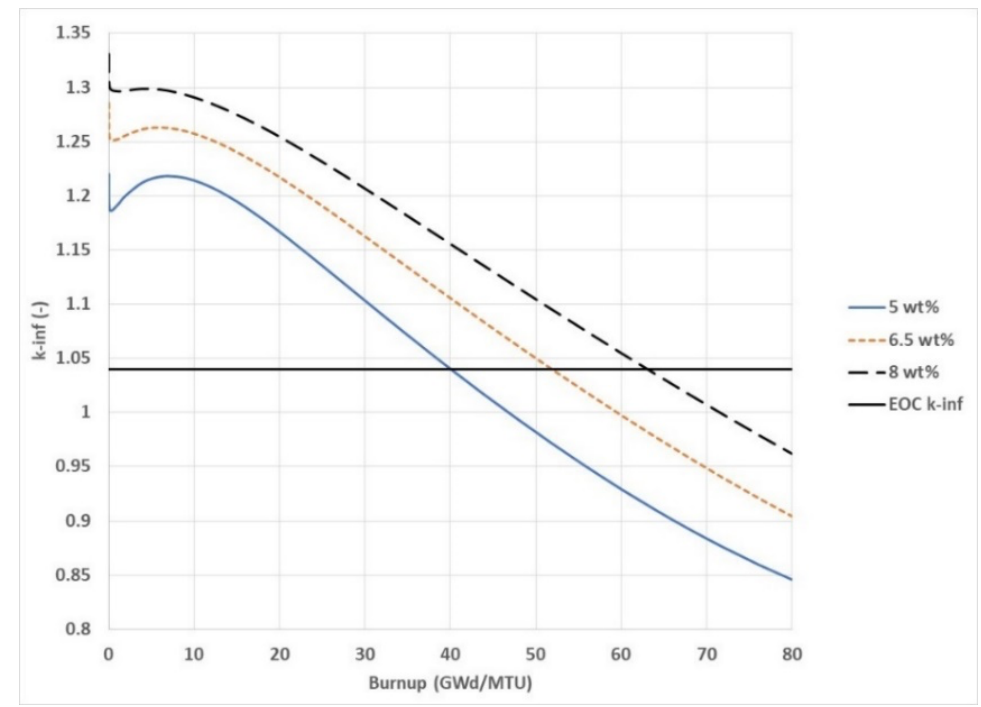

Figure 9. HFP depletion $k_{\text {inf }}(0 \mathrm{ppm}$ soluble boron). 
As illustrated in Figure 10, the effect of DTC becomes less pronounced with increased enrichment and more pronounced with increasing burnup. Doppler broadening in ${ }^{238} \mathrm{U}$ primarily results in neutron capture (negative DTC). In fissile materials such as ${ }^{235} \mathrm{U}$, Doppler broadening increases fission (positive DTC). Higher enrichment fuel increases the positive fissile contribution to DTC. Higher burnup reduces the positive fissile contribution to DTC. Based on the expected increase in core average burnup with increased enrichment (Figure 9), the estimated core average DTC (EOC estimate) is small due to offsetting effects of increased enrichment and increased burnup.

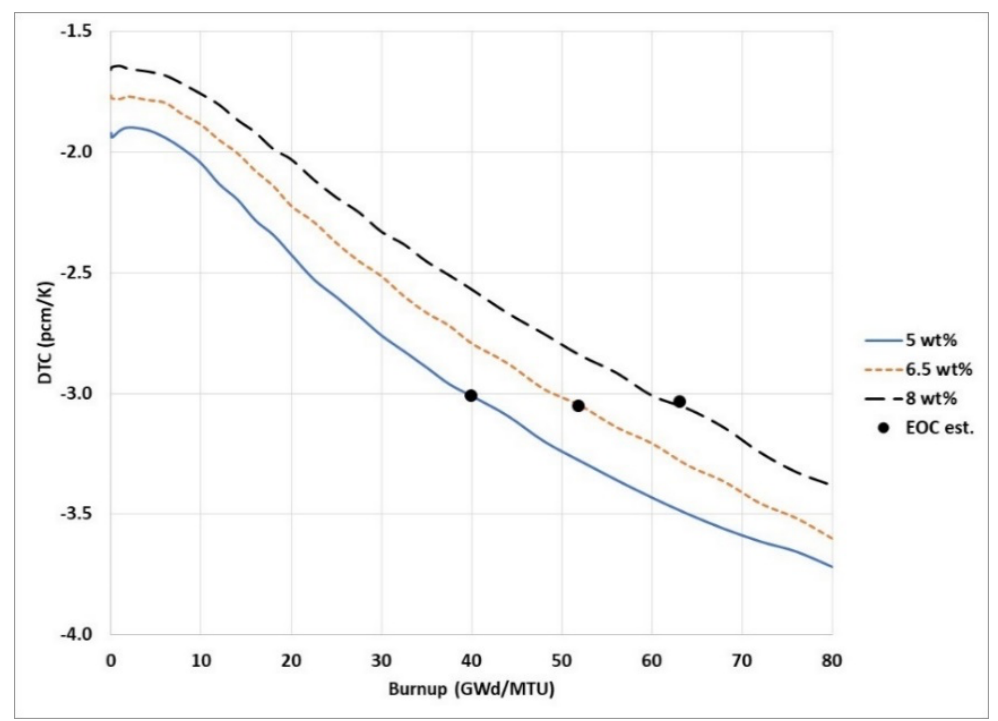

Figure 10. HFP DTC.

The sign and magnitude of the MTC depends primarily on trade-offs between the effect of lower water density on fission and absorption cross sections. Less moderation (water density decrease due to temperature increase) hardens the neutron spectrum, reducing fission cross sections and $1 / \mathrm{v}$ absorber cross sections, but it reduces neutron absorption by water. Figure 10 shows that the MTC becomes more positive with increased enrichment and more negative with increasing burnup. The estimated EOC core average MTC is expected to become somewhat more negative because the effect of increased burnup is larger than the effect of increased enrichment.

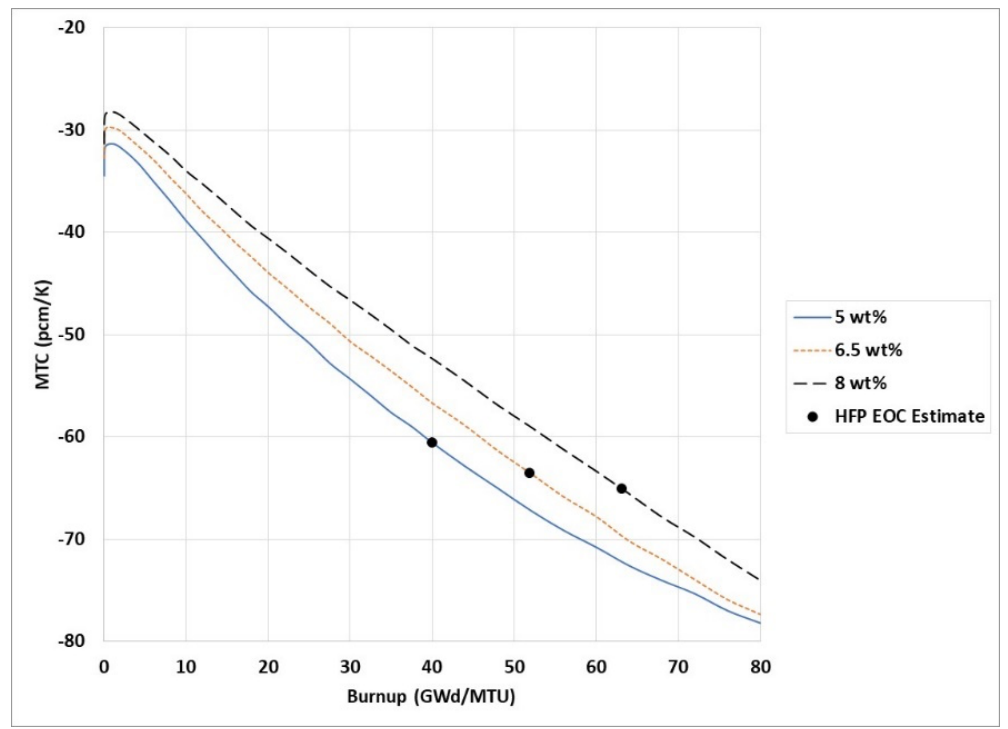

Figure 11. HFP MTC (no soluble boron). 
Increased enrichment causes absorption hardening of the neutron spectrum, which significantly reduces the worth of $\mathrm{Ag} / \mathrm{In} / \mathrm{Cd}$ control rods, which are predominantly thermal absorbers that compete with ${ }^{235} \mathrm{U}$ for thermal neutrons. As shown in Figure 12 control rod worth declines $\sim 9 \% / \mathrm{wt} \%{ }^{235} \mathrm{U}$ at the same burnup and $\sim 5 \% / \mathrm{wt} \%{ }^{235} \mathrm{U}$ at the expected EOC burnup for each core average enrichment.

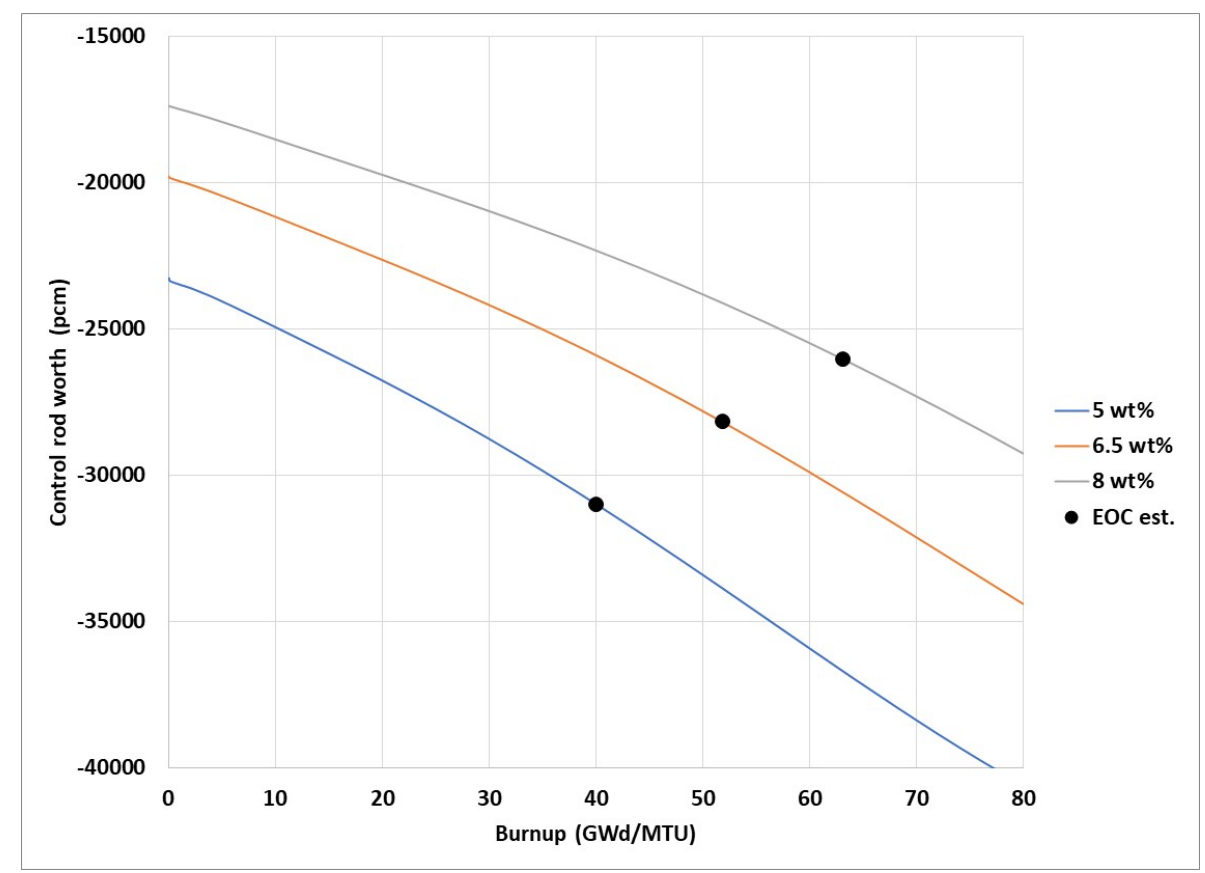

Figure 12. HFP control rod worth.

\subsection{CROSS SECTION LIBRARY AND CODE VERSION EFFECTS}

The 5 and $8 \mathrm{wt} \%$ depletions were run with the SCALE 252-group and 56-group ENDF/B-VII.1 libraries to evaluate the performance of the 56-group library with EE and HBU. Figure 13-Figure 16 indicate that differences increase with burnup and decline with increased enrichment. Differences with $8 \mathrm{wt} \%$ are generally within the range of differences with $5 \mathrm{wt} \%$ and 0 to $60 \mathrm{GWd} / \mathrm{MTU}$.

As shown in Figure 13 below, differences in $k_{\text {inf }}$ using the two cross section libraries trend more positive with increasing burnup beyond $\sim 40 \mathrm{GWd} / \mathrm{MTU}$. The $8 \mathrm{wt} \% 56$-group depletion $\mathrm{k}_{\text {inf }}$ is biased more negative than the $5 \mathrm{wt} \% \mathrm{k}_{\text {inf. }}$. The maximum difference is smaller for the higher enrichment, possibly because the importance of $\mathrm{Pu}$ is less for higher enrichments (Figure 2). 


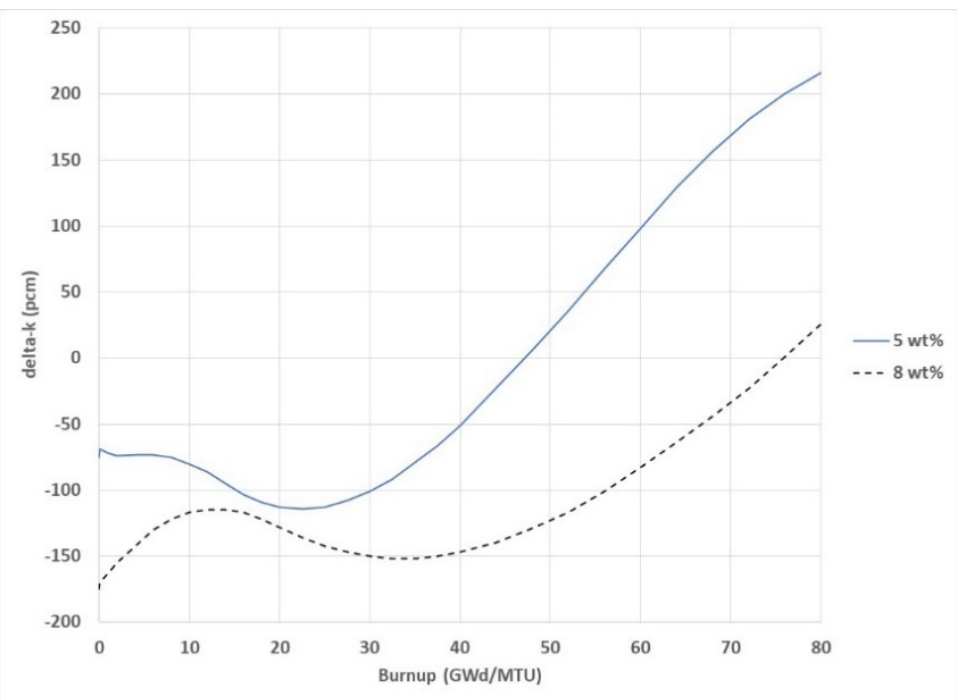

Figure 13. HFP $k_{\text {inf }}$ cross section library difference ( $k_{\text {inf }} 56$ - and $k_{\text {inf }} 252$-group).

Cross section library DTC difference trends are similar for both enrichments. The maximum difference for either enrichment is about $2 \%$ of the DTC. In Figure 14, the jagged nature of the curves is due to $\mathrm{k}_{\text {inf }}$ roundoff to the nearest $\mathrm{pcm}$ in the Polaris output file.

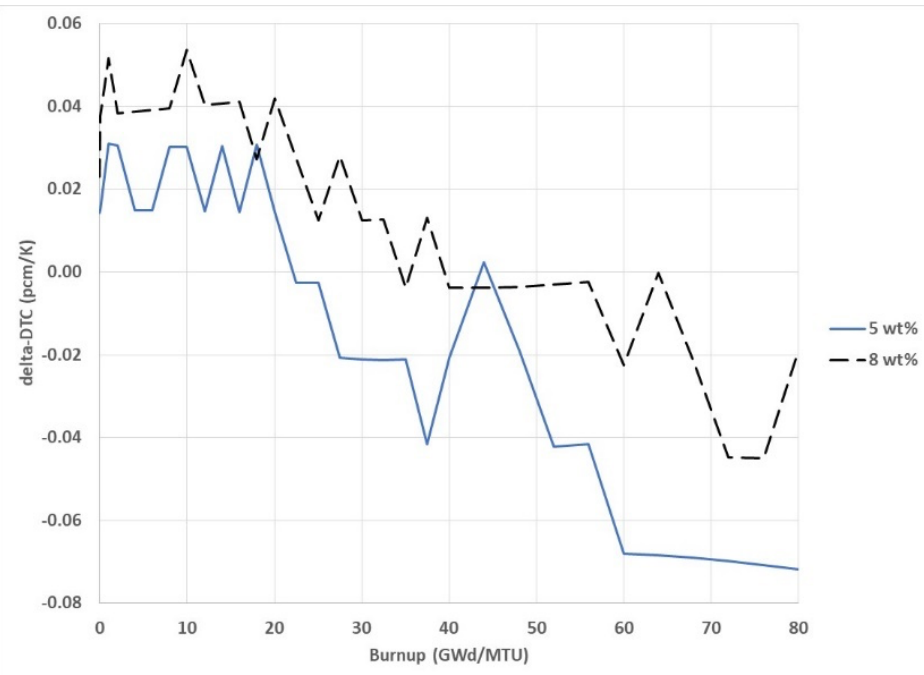

Figure 14. HFP DTC cross section library difference (56- and 252-group).

As shown in Figure 15, the 56-group library tends to produce more negative MTCs than the 252-group library for both enrichments. The trend with burnup is similar, but it is more pronounced with $5 \mathrm{wt} \%$. The jagged nature of the curves is due to $\mathrm{k}_{\text {inf }}$ roundoff to the nearest $\mathrm{pcm}$ in the Polaris output file. 


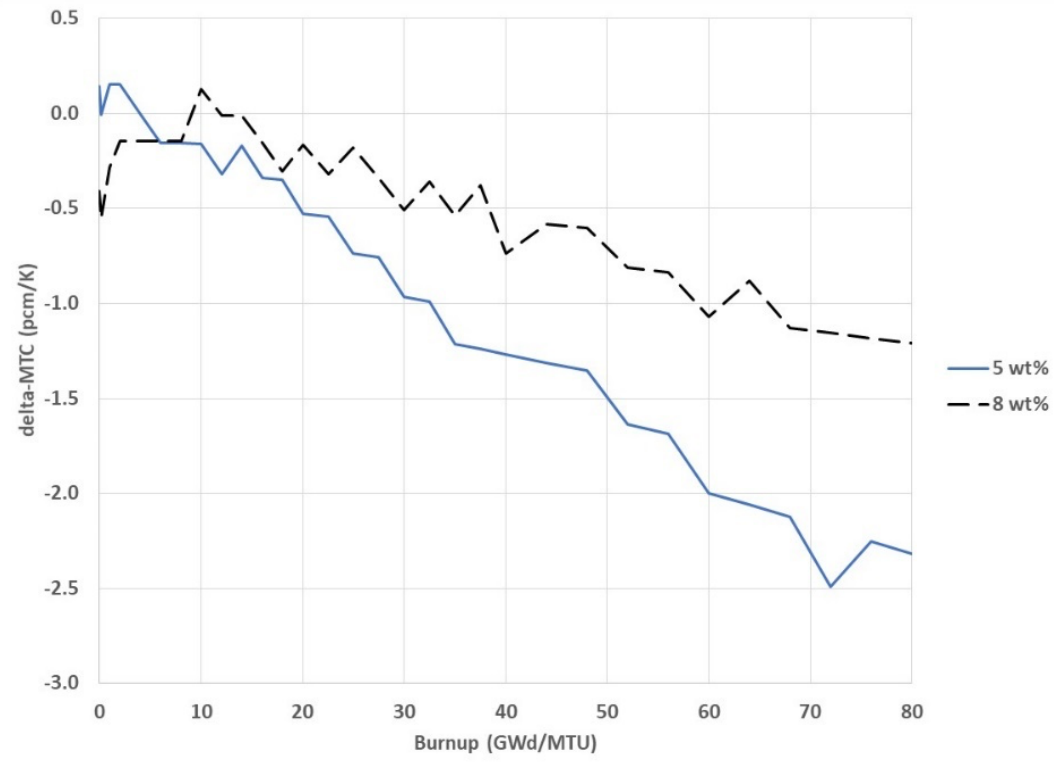

Figure 15. HFP MTC cross section library difference (56- and 252-group).

The 56-group library generally produces slightly less negative BW than the 252-group library, as illustrated in Figure 16. BW difference trends are similar for both enrichments but are more pronounced with $5 \mathrm{wt} \%$. The maximum difference is about $1.4 \%$ of the $\mathrm{BW}$.

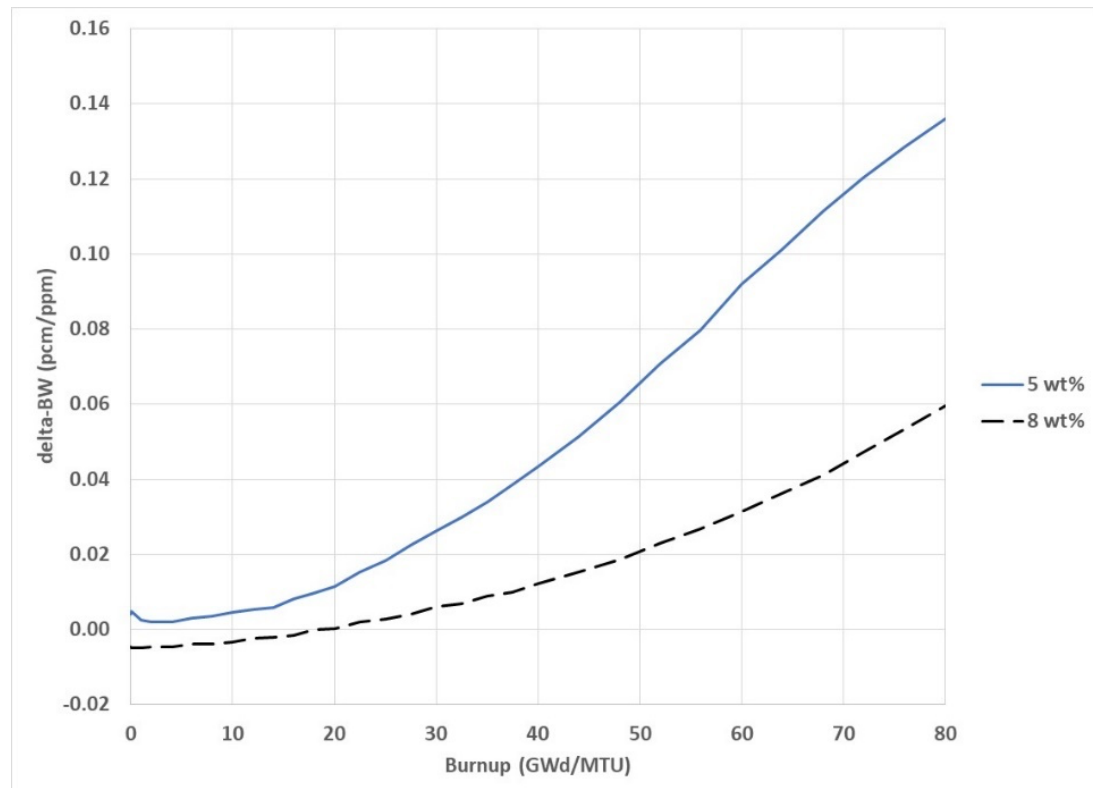

Figure 16. HFP BW cross section library difference (56 - and 252-group).

The 56-group library produces smaller CRW magnitude than the 252-group library (Figure 17). CRW difference trends are similar for both enrichments but are more pronounced with $5 \mathrm{wt} \%$. 


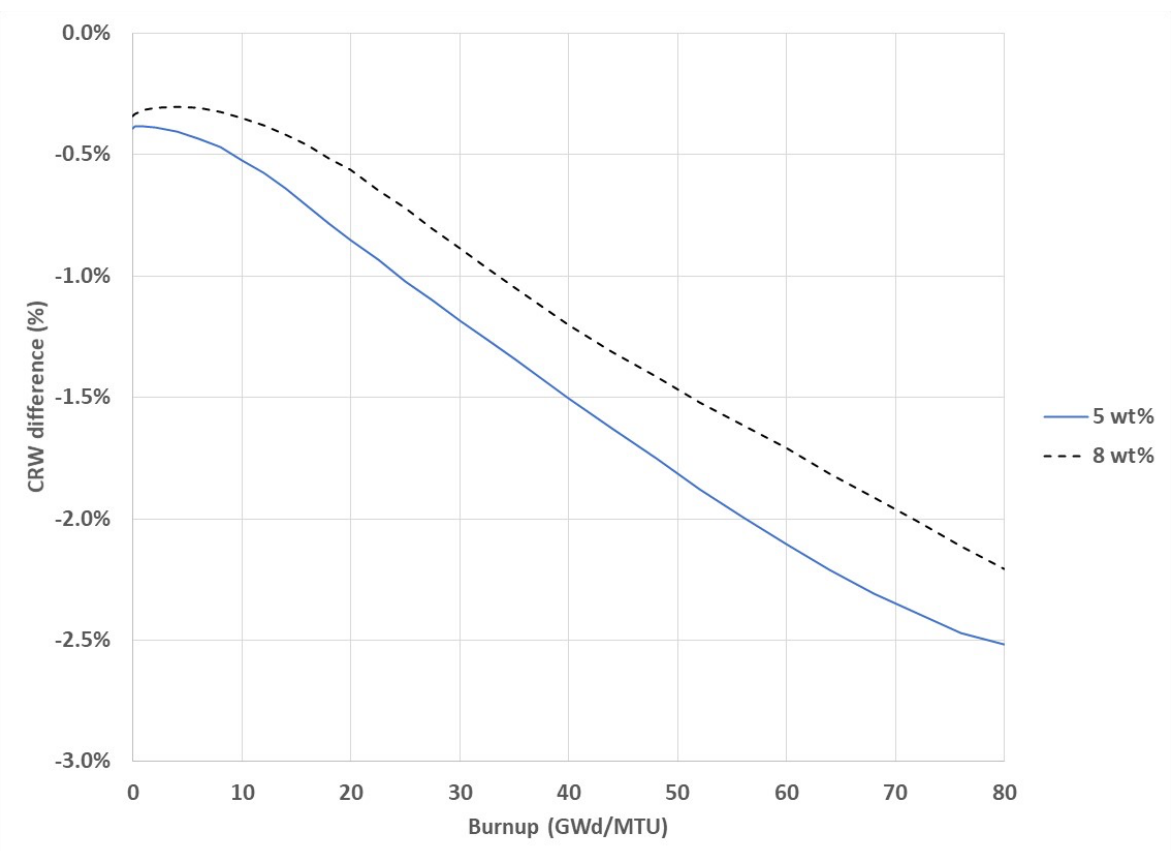

Figure 17. HFP control rod worth cross section library difference (56-group vs 252-group).

During this work, pre-release SCALE 6.3 nuclear data and codes were assessed for HALEU and HBU modeling, and compared to results from the production release, SCALE 6.2. Figure 18 shows that the $17 \times 17$ assembly Polaris 56-group ENDF/B-VII depletion $\mathrm{k}_{\text {inf }}$ results differ slightly between code versions with the changes in 6.3 a result of minor method and library improvements. These small differences do not affect any results in this report and where coefficients or worths are calculated, the depletions or branch cases are performed with the same code version for consistency.

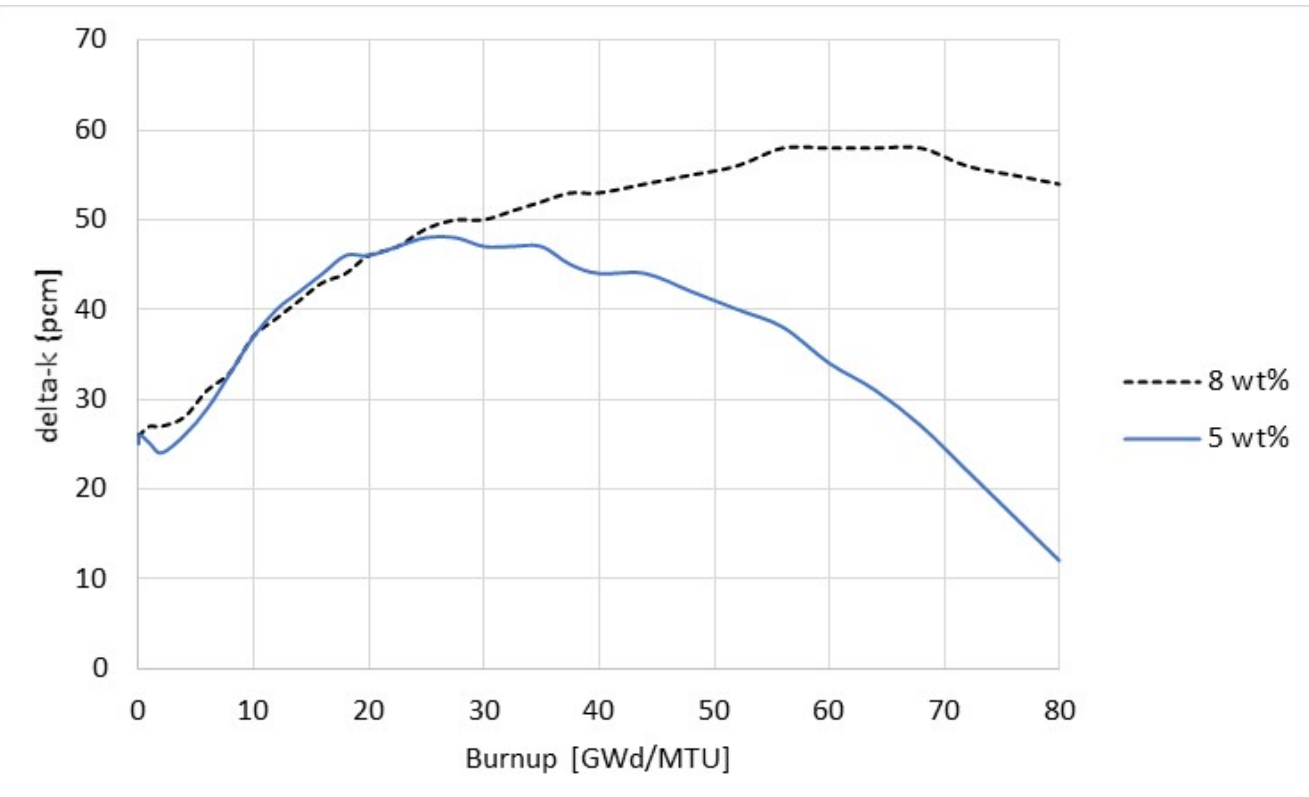

Figure 18. HFP 56-group Polaris SCALE pre-release 6.3 lattice kinf - SCALE 6.2 lattice kinf. 


\subsection{COMPARISON OF TRITON AND POLARIS DEPLETIONS}

Pin-cell depletions with $8 \mathrm{wt} \%$ fuel were run with Polaris and TRITON-KENO (T6-depl sequence) to assess the bias in Polaris MG calculations. TRITON-KENO calculations were performed with continuous energy, 252-group, and 56-group ENDF/B-VII.1 libraries. This comparison was conducted to evaluate the performance of the 56-group library with EE and HBU fuels. Differences in $\mathrm{k}_{\text {inf }}$ are shown in Figure 19. Higher order cases were run with looser convergence to manage run times ( $\mathrm{k}_{\text {inf }}$ convergence level indicated in Figure 19 data labels).

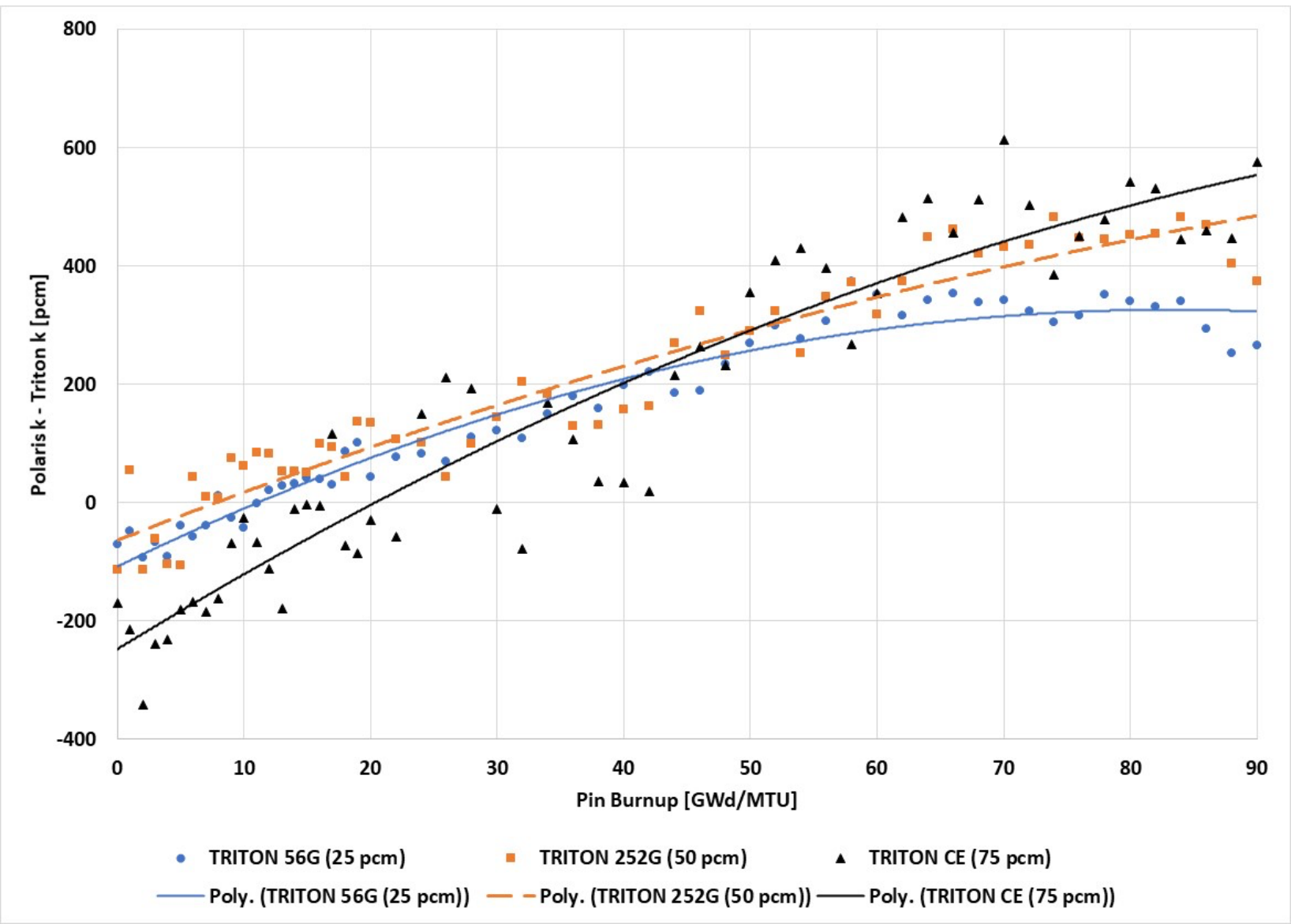

Figure 19. HFP 8 wt\% 56-group Polaris pin-cell depletion $k_{\text {inf }}$ - TRITON-KENO $k_{\text {inf. }}$

Notes: The overall trend is for Polaris $\mathrm{k}_{\text {inf }}$ to be slightly lower than TRITON-KENO initially and then to trend higher throughout the depletion. No large differences between the models were seen; however, differences at $\mathrm{HBU}(>50 \mathrm{GWd} / \mathrm{MTU})$ are large enough to warrant additional evaluation.

\subsection{PIN POWER AND BURNUP DISTRIBUTIONS}

Pin power and burnup distributions for three Polaris depletions were extracted and/or calculated from information in the Polaris output files.

- Maximum and minimum relative pin power vs assembly burnup: extracted from the "Fission Density Peaking Factors" section 
- Maximum and minimum relative pin burnup versus assembly burnup

- Pin power is integrated over burnup to obtain pin burnup using the "Material Flux and Power Levels over Burnup Step" section

- Relative pin burnup is normalized to assembly average burnup

$\circ$ Pin burnup is an integral part of pin power, but it also includes the effect of pin power redistribution in the lattice over the burnup range

- Average pin relative ring power for inner, middle, and outer fuel rings

- Calculated from pin ring power in the "Material Flux and Power Levels over Burnup Step" section

- Each ring power is averaged over all fuel pins and normalized to the assembly average pin power

Data are presented in a series of figures below, with accompanying comments identifying notable trends. Relative power and burnup values are unitless.

As shown in Figure 20, maximum relative pin power increases with increasing enrichment due to the increased local effect of high moderation regions (e.g., guide tubes) when the lattice flux spectrum is harder. All enrichments show a trend-vs-burnup characteristic of rapid IFBA burnout followed by gradual flattening of the lattice power distribution. Peak power occurs at higher burnup with increased enrichment due to the delayed IFBA burnout in harder energy spectra.

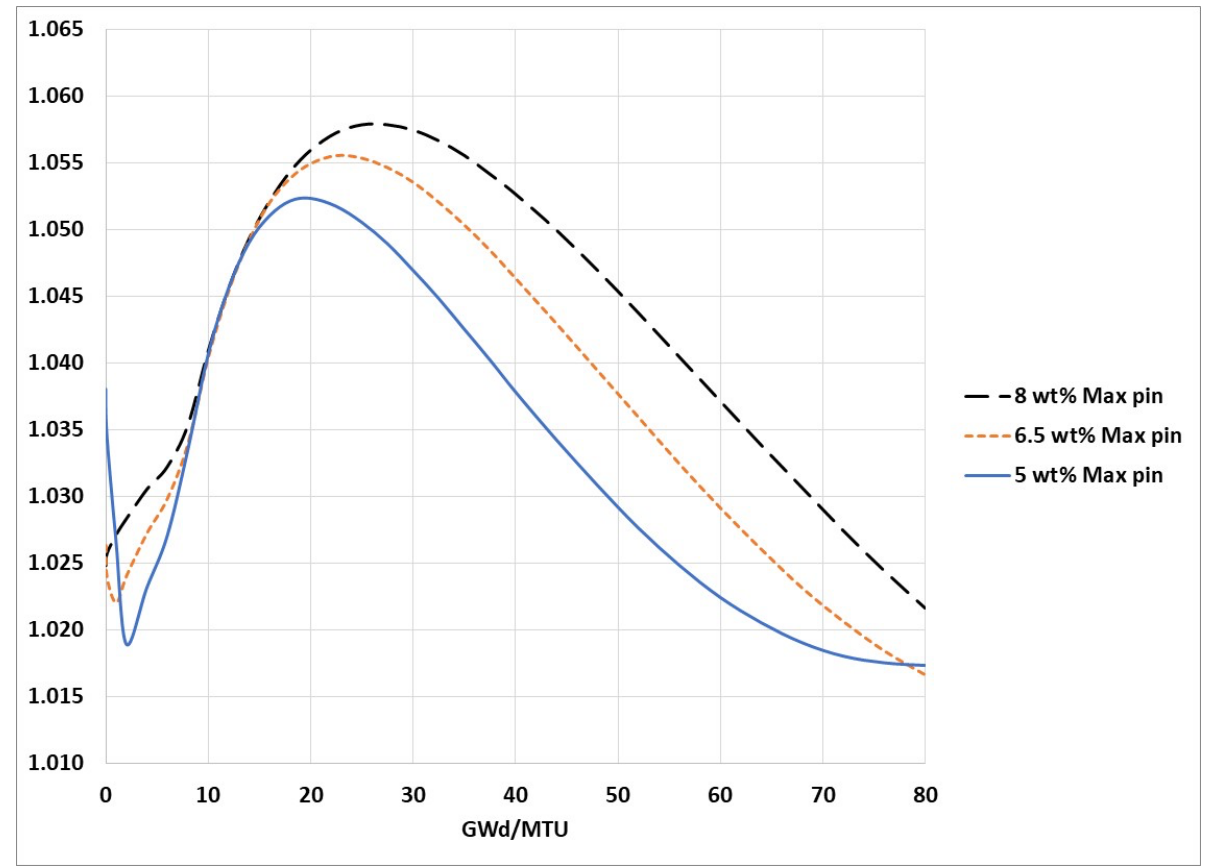

Figure 20. HFP maximum relative pin power.

Figure 21 shows how minimum pin power rises with burnup. Lower than average pins have accumulated burnup deficit. This tends to preserve their reactivity at a higher value than other pins. That then offsets the local geometry effects (e.g., far from high moderation regions) causing the low pin power, and pin power trends toward the assembly average. Minimum power is lower for higher enrichment because high power pins are higher (average pin power is constant). 


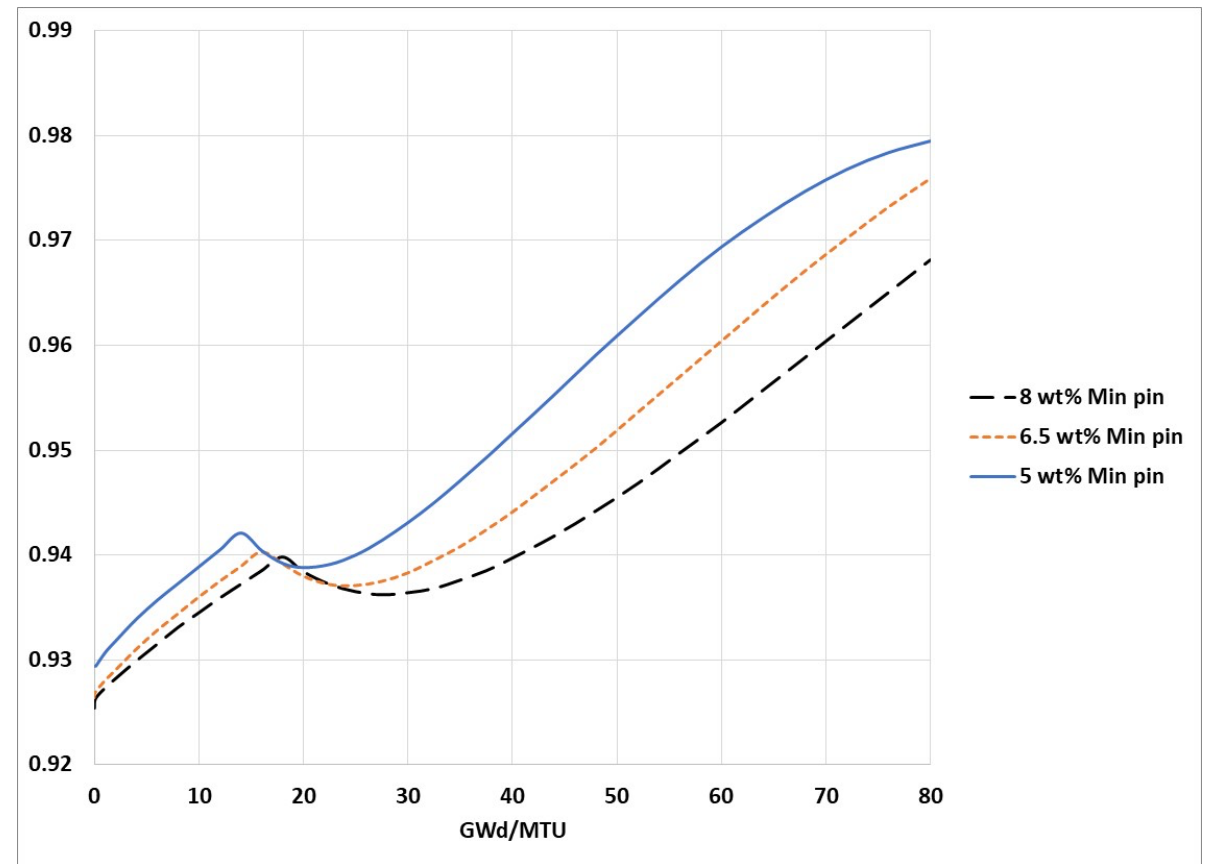

Figure 21. HFP minimum relative pin power.

As seen in Figure 22, maximum pin burnup increases with increasing enrichment, mirroring the pin power trend. As with pin power, peak relative burnup occurs later in burnup for higher enrichments.

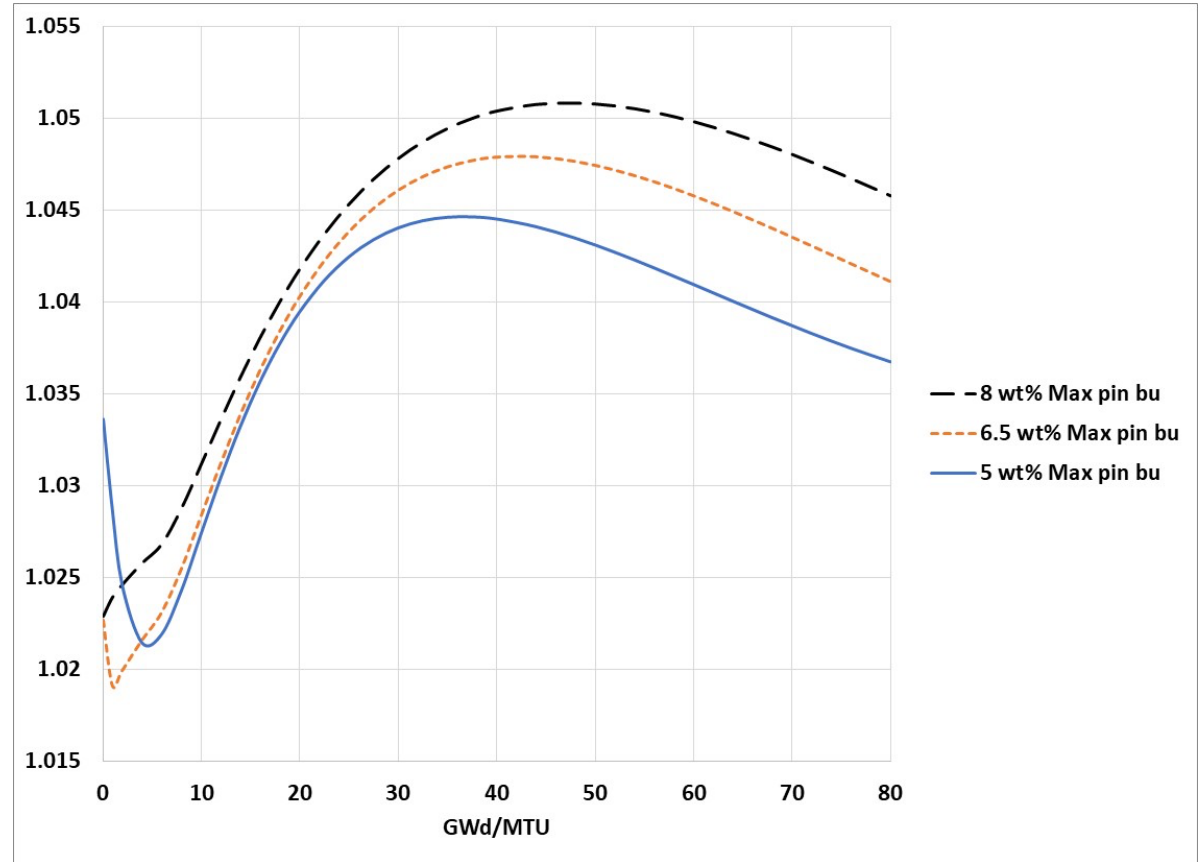

Figure 22. HFP maximum relative pin burnup.

Figure 23 shows that higher absorption (fission + capture) cross sections due to increased enrichment initially increase fuel pin radial self shielding (lower inner ring power). Increased enrichment reduces the 
importance of $\mathrm{Pu}$ at higher burnup due to higher ${ }^{235} \mathrm{U} / \mathrm{Pu}$, leading to a reduced rim effect (higher inner ring power).

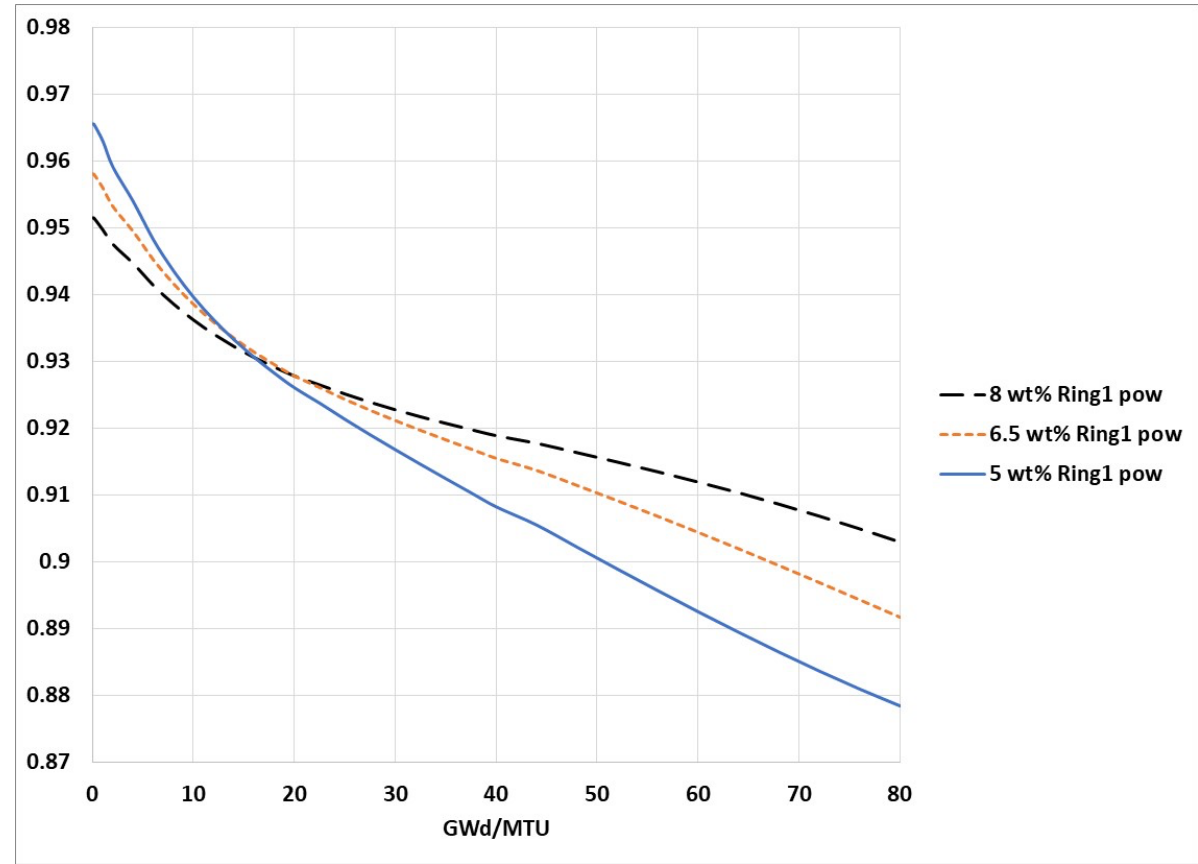

Figure 23. HFP relative inner ring pin power.

Similar to the inner ring, increased enrichment results in reduced rim effect (middle ring power closer to pellet average), as illustrated in Figure 24.

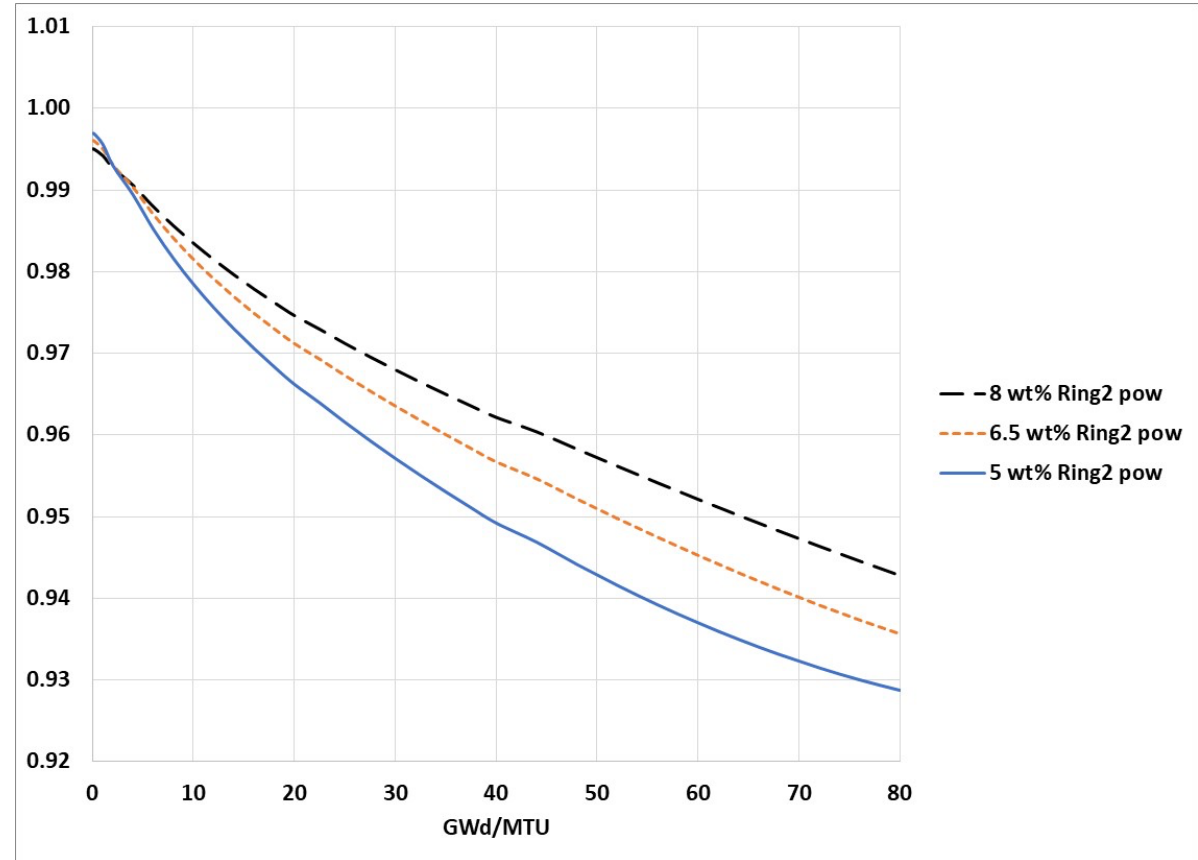

Figure 24. HFP relative middle ring pin power. 
Figure 25 shows how increased enrichment initially increases pellet self shielding (lower inner ring power and higher outer ring power). Increased enrichment reduces the importance of $\mathrm{Pu}$ at higher burnup due to higher ${ }^{235} \mathrm{U} / \mathrm{Pu}$, leading to reduced rim effect (decreased outer ring power at higher burnups).

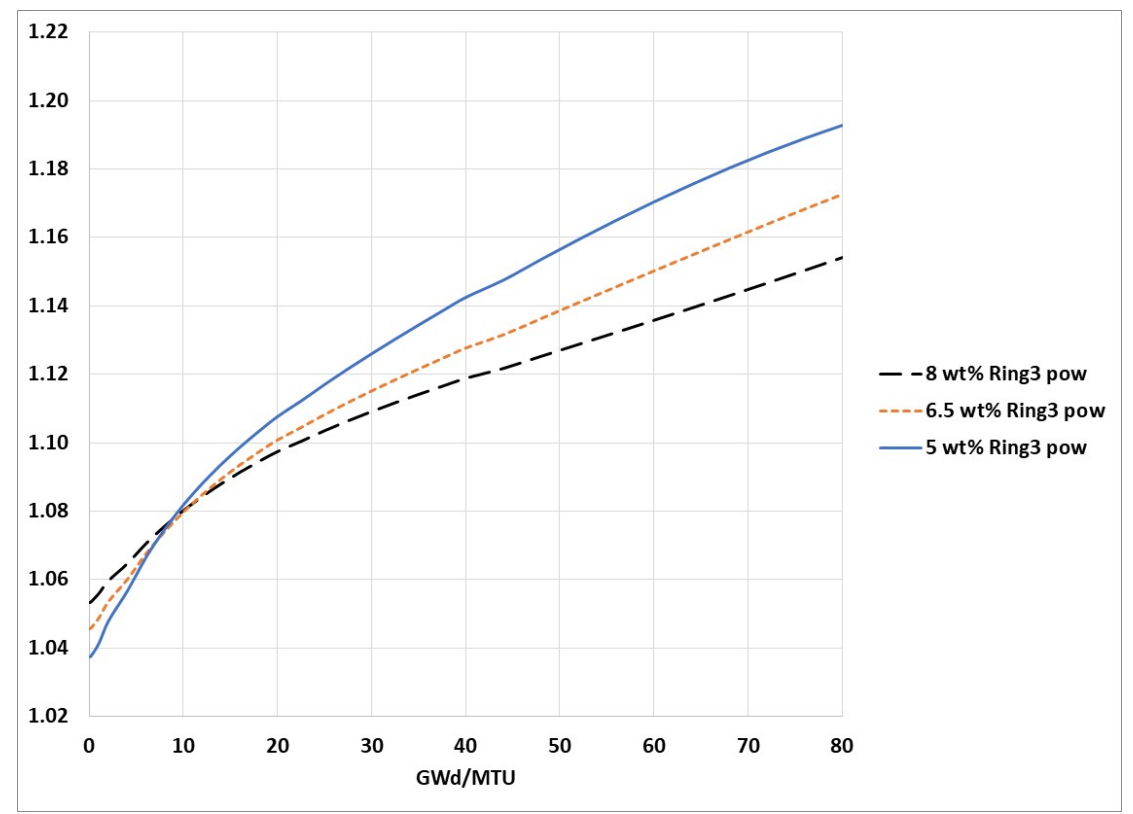

Figure 25. HFP relative outer ring pin power.

\subsection{MACROSCOPIC CROSS SECTIONS}

Polaris calculates multiple burnup-dependent lattice macroscopic cross sections, kinetics parameters, and other values that are of use in core modeling nodal codes. In order to identify trends and potential anomalies, comparisons of these parameters from the 5, 6.5, and $8 \mathrm{wt} \%$ depletions are presented in the following figures with accompanying comments. Table 2 lists the parameter names and descriptions. Data are presented in three subsections: four-factor formula, lattice cross sections, and kinetics parameters.

Table 2. Lattice parameters

\begin{tabular}{lllc}
\hline \multicolumn{1}{c}{ Name } & \multicolumn{1}{c}{ Type } & \multicolumn{1}{c}{ Description } & Units \\
\hline Eta & 4-factor formula & Reproduction factor $\eta$ & - \\
$\mathrm{f}$ & 4-factor formula & Thermal utilization factor $f$ & - \\
\hline $\mathrm{p}$ & 4-factor formula & Resonance escape probability $p$ & - \\
\hline eps & 4-factor formula & Fast fission factor $\varepsilon$ & $1 / \mathrm{cm}$ \\
\hline Removal1 & Macroscopic xs & Fast removal cross section & $1 / \mathrm{cm}$ \\
\hline Eff Abs1 & Macroscopic xs & Fast effective absorption cross section & $1 / \mathrm{cm}$ \\
\hline Fiss1 & Macroscopic xs & Fast fission cross section & $1 / \mathrm{cm}$ \\
\hline Removal2 & Macroscopic xs & Thermal removal cross section & $1 / \mathrm{cm}$ \\
\hline Eff Abs2 & Macroscopic xs & Thermal effective absorption cross section & $1 / \mathrm{cm}$ \\
\hline Fiss2 & Macroscopic xs & Thermal fission cross section & - \\
\hline B-eff & Kinetics & Effective delayed neutron fraction & $1 / \mathrm{sec}$ \\
\hline L-eff & Kinetics & Effective delayed neutron decay constant & \\
\hline
\end{tabular}




\subsubsection{Four-Factor Formula}

The component parts of the four-factor formula are as follows:

$\eta$ : neutrons produced from fission per neutron absorbed in fuel,

$f$ : thermal neutrons absorbed in fuel per thermal neutron absorbed in the system,

$p$ : fraction of fission neutrons escaping resonance capture and reaching thermal energy, and

$\varepsilon$ : fast neutrons produced by fission per fast neutron produced by thermal fission.

Each of the four factors is a unitless ratio. In general, trends for these four factors with increasing ${ }^{235} U$ enrichment are due to increased fissile content in the fuel, along with spectrum hardening resulting from the increased fissile content. Since there are no physical changes to the lattice that would change the H/U ratio and no changes to depletion conditions (soluble BW is equivalent for each enrichment), spectrum hardening is the result of increased thermal neutron absorption by fissile isotopes rather than reduced moderation.

In Figure 26, eta is defined as fission neutrons produced per absorption in fuel. ${ }^{235} \mathrm{U}$ has a higher $\eta$ than ${ }^{238} \mathrm{U}$, so increased ${ }^{235} \mathrm{U}$ enrichment increases $\eta$. Figure 2 above shows that EE's increased fissile content persists throughout the depletion. The general shape of each curve reflects xenon build-in (increased absorption), followed by the rapid burnout of IFBA (decreased absorption), followed by fissile content depletion and buildup of parasitic fission products and actinides (reduced fission cross section and increased absorption cross section).

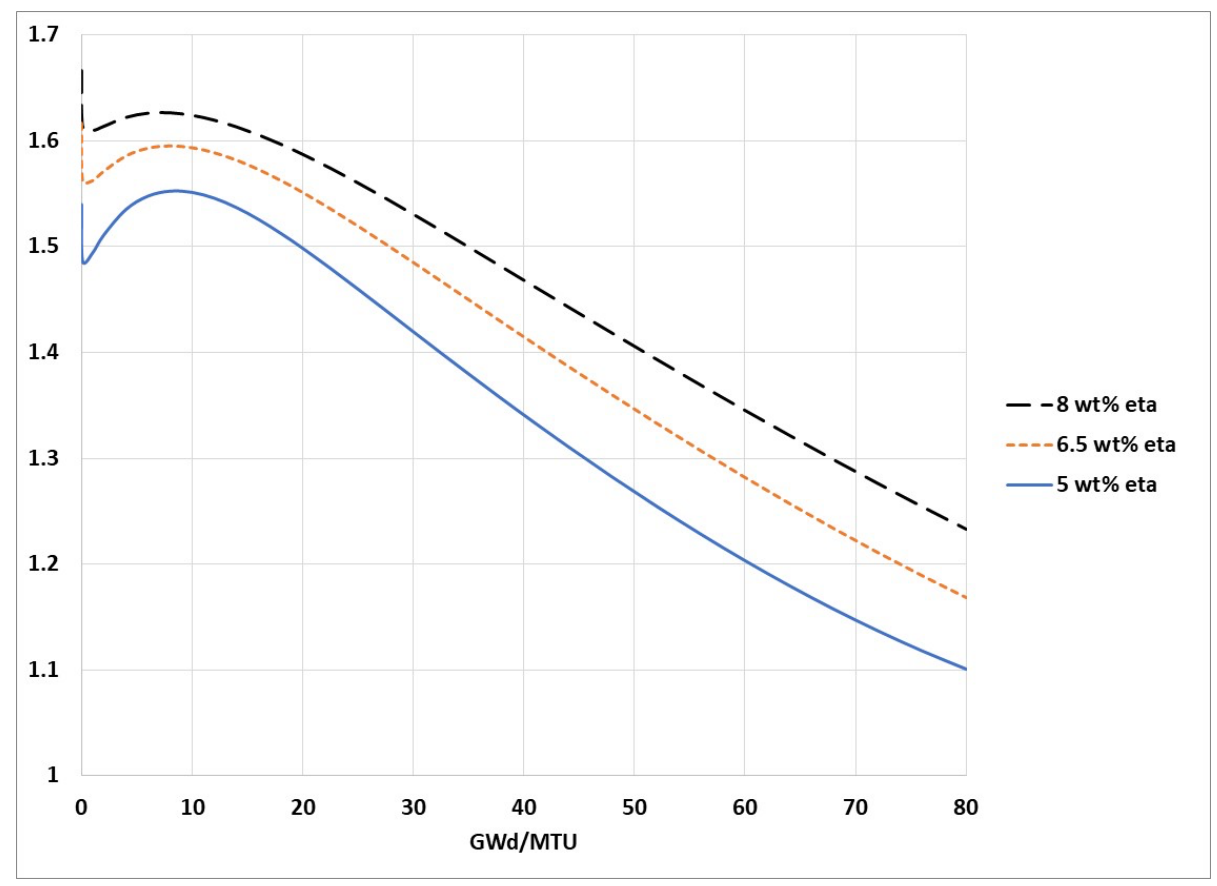

Figure 26. HFP four-factor $\eta$ (reproduction).

In Figure 27, $f$ is defined as the neutrons absorbed in the fuel per neutrons absorbed in the system. Equivalent soluble boron worth for the three depletions results in approximately the same neutron absorption in the moderator, so the differences in thermal utilization are very small. Trends are due to second-order effects. With assembly depletion power held constant, thermal flux is decreased in EE fuel, which decreases thermal neutron absorption in both fuel (numerator of $f$ ) and non-fuel (denominator of $f$ ) portions of the lattice, resulting in $f$ very similar to the reference $5 \mathrm{wt} \%$ condition. 


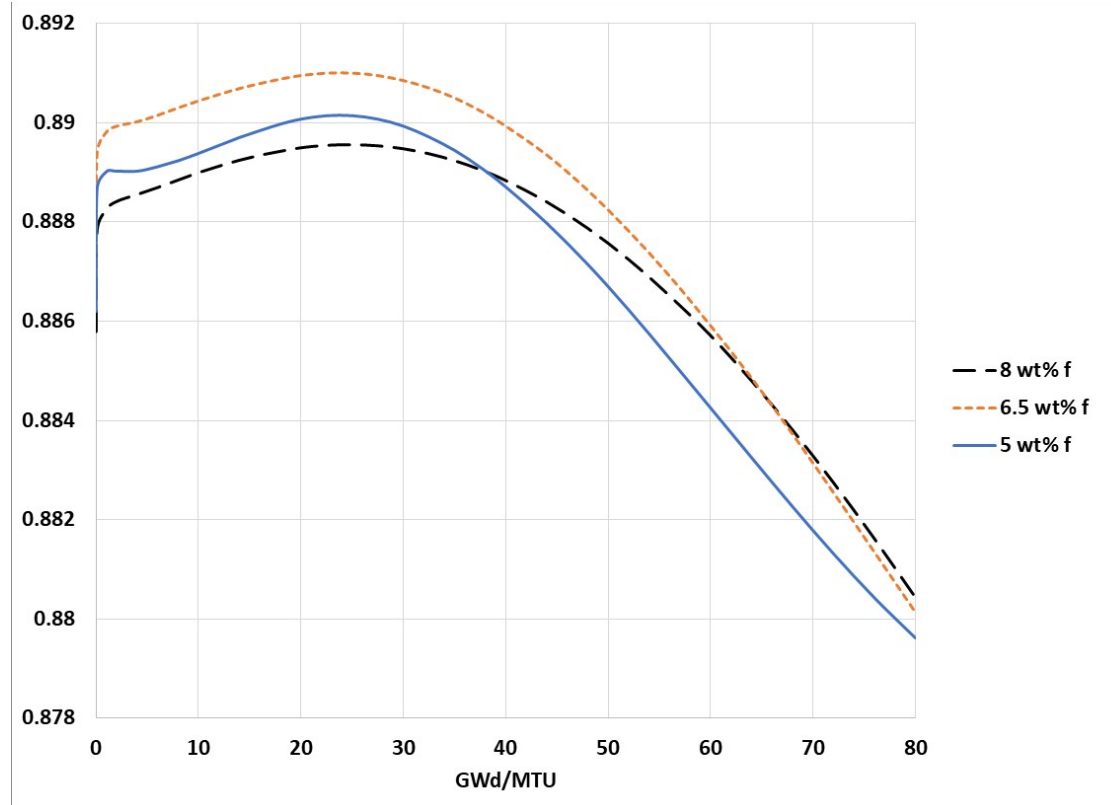

Figure 27. HFP four-factor $f$ (thermal utilization).

In Figure 28, $p$ is defined as fission neutrons slowed to thermal energies without absorption as a fraction of total fission neutrons. The microscopic ${ }^{235} \mathrm{U}$ absorption cross section over most of the fast group range $(>0.625 \mathrm{eV})$ is much larger than the ${ }^{238} \mathrm{U}$ absorption cross section. With fission rate essentially constant for all three enrichments (constant depletion power), the $p$ denominator is nearly unchanged by EE.

Replacing ${ }^{238} \mathrm{U}$ with ${ }^{235} \mathrm{U}$ increases absorption of fast neutrons and reduces the numerator of $p$. Figure 2 above shows that EE-increased ${ }^{235} \mathrm{U}$ content persists throughout the depletion.

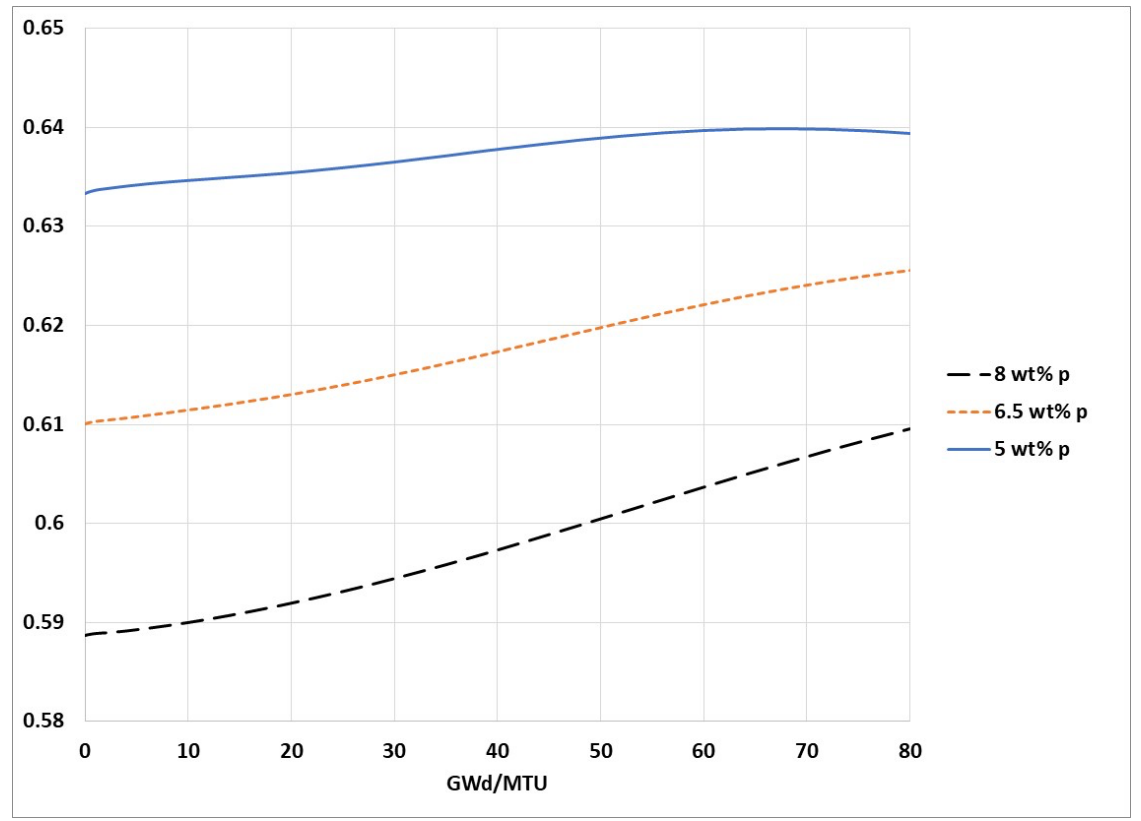

Figure 28. HFP four factor $p$ (resonance escape probability).

In Figure 29, $\varepsilon$ is defined as the number of total fission neutrons per thermal fission neutron. Increasing fissile content increases the proportion of thermal fissions (reduces $\varepsilon$ ). Increased fissile content also 
produces neutron spectrum absorption hardening, which increases the fast-to-thermal flux ratio, thereby reducing the proportion of thermal fissions (increases $\varepsilon$ ). Absorption hardening also shifts the thermal group average neutron energy higher, resulting in lower microscopic thermal fission cross sections (increases $\varepsilon$ ). The net effect is an increase in $\varepsilon$ with increasing enrichment.

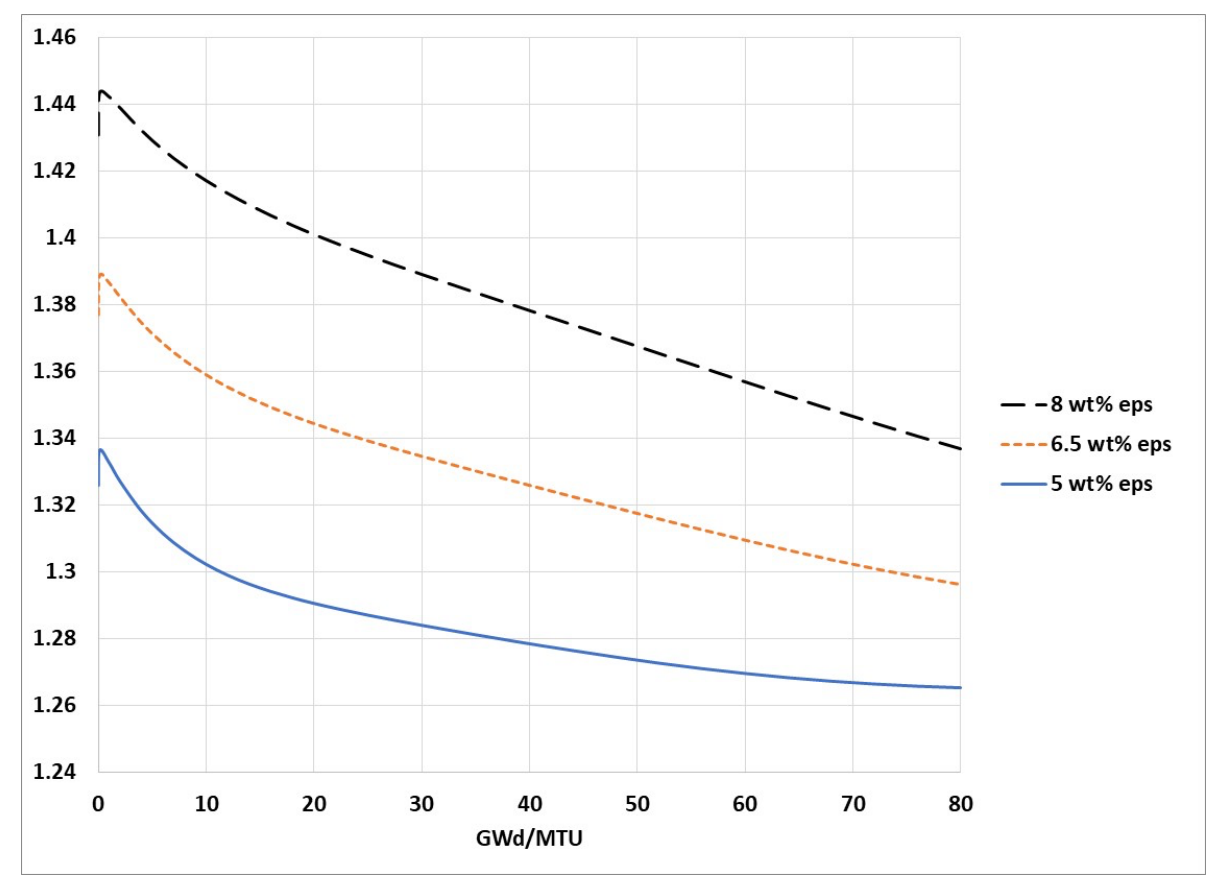

Figure 29. HFP four factor $\varepsilon$ (fast fission factor).

\subsubsection{Lattice Cross Sections}

Two-group lattice cross sections are presented graphically as a means of visualizing the effects of EE and HBU and as a way to identify anomalous trends for further investigation. Some parameter trends are easily understood through the lens of increased fissile content or spectrum hardening. Some are the result of combinations of factors that are not obvious. The Polaris two-group neutron energy structure designators are fast $(>0.625 \mathrm{eV})$ and thermal $(\leq 0.625 \mathrm{eV})$. Units are provided on plots for parameters that are not unitless quantities. 
In Figure 30, the fast removal cross section includes contributions from downscatter (moderation) as well as absorption, resulting in a complex trend. For example, although ${ }^{10} \mathrm{~B}$ is primarily a thermal absorber, the influence of IFBA depletion is visible at $\sim 10 \mathrm{GWd} / \mathrm{MTU}$, and it varies with enrichment. Moderation is essentially constant because the amount of water in the lattice is the same for each depletion. Differences in the fast removal cross section among the different enrichments are very small $(\sim 1 \%)$.

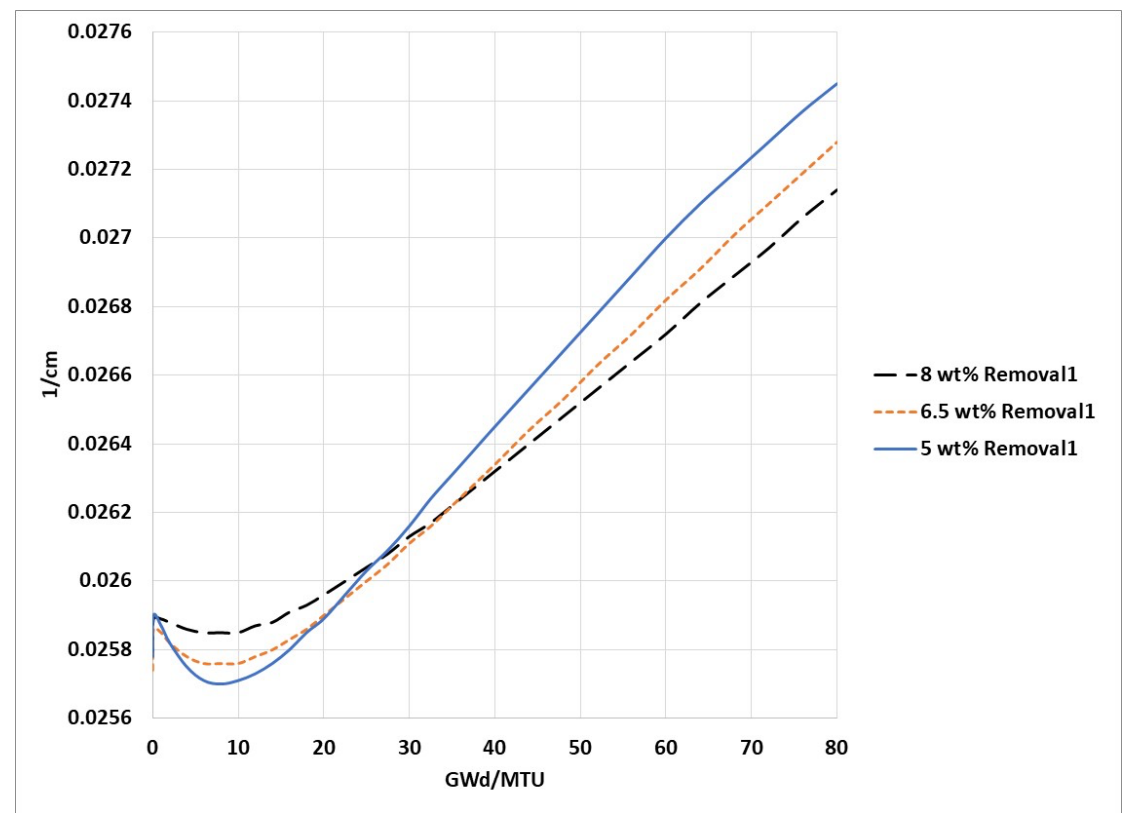

Figure 30. HFP fast removal cross section.

Figure 31 shows that the fast absorption cross section for ${ }^{235} \mathrm{U}$ is much larger than for ${ }^{238} \mathrm{U}$, so increased enrichment increases the fast absorption cross section significantly.

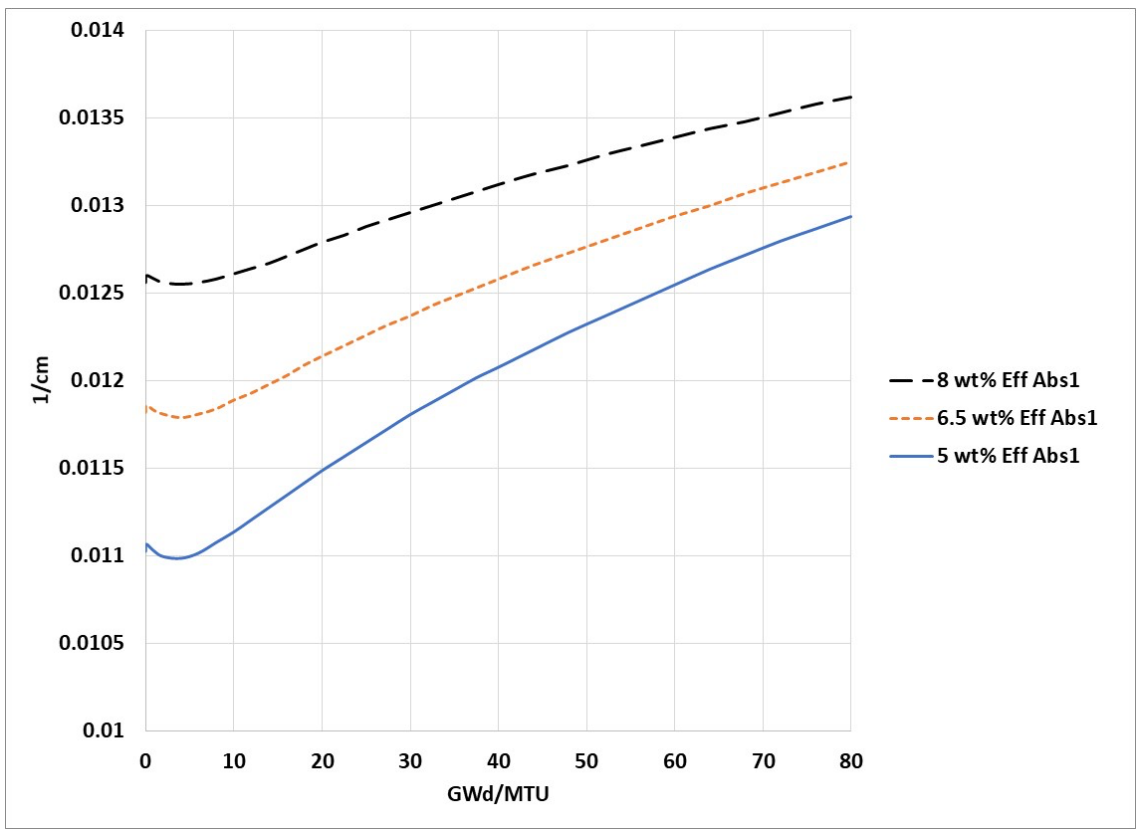

Figure 31. HFP fast effective absorption cross section. 
The SCALE 252-group ${ }^{235} \mathrm{U}$ and ${ }^{238} \mathrm{U}$ neutron absorption cross section (barns) vs energy (eV) is shown for reference in Figure 32.

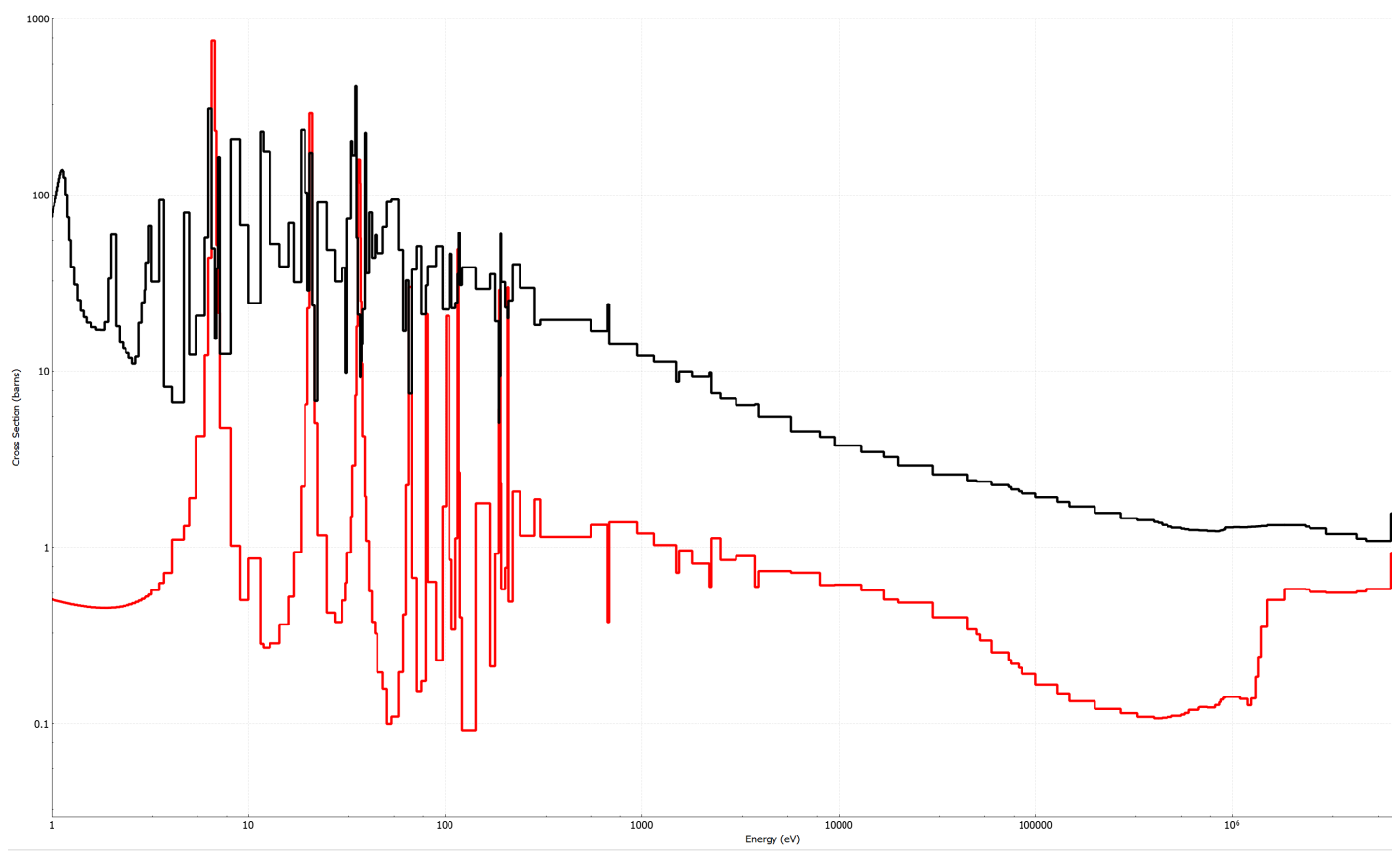

Figure 32. ${ }^{235} \mathrm{U}$ (black) and ${ }^{238} \mathrm{U}$ (red) absorption cross section (barns) vs energy (eV).

As Figure 33 indicates, the fast fission cross section is primarily a function of the sum of the fissile content (Figure 2) and the ${ }^{238} U$ content. ${ }^{238} U$ content is very similar for the three enrichments and is relatively constant with burnup.

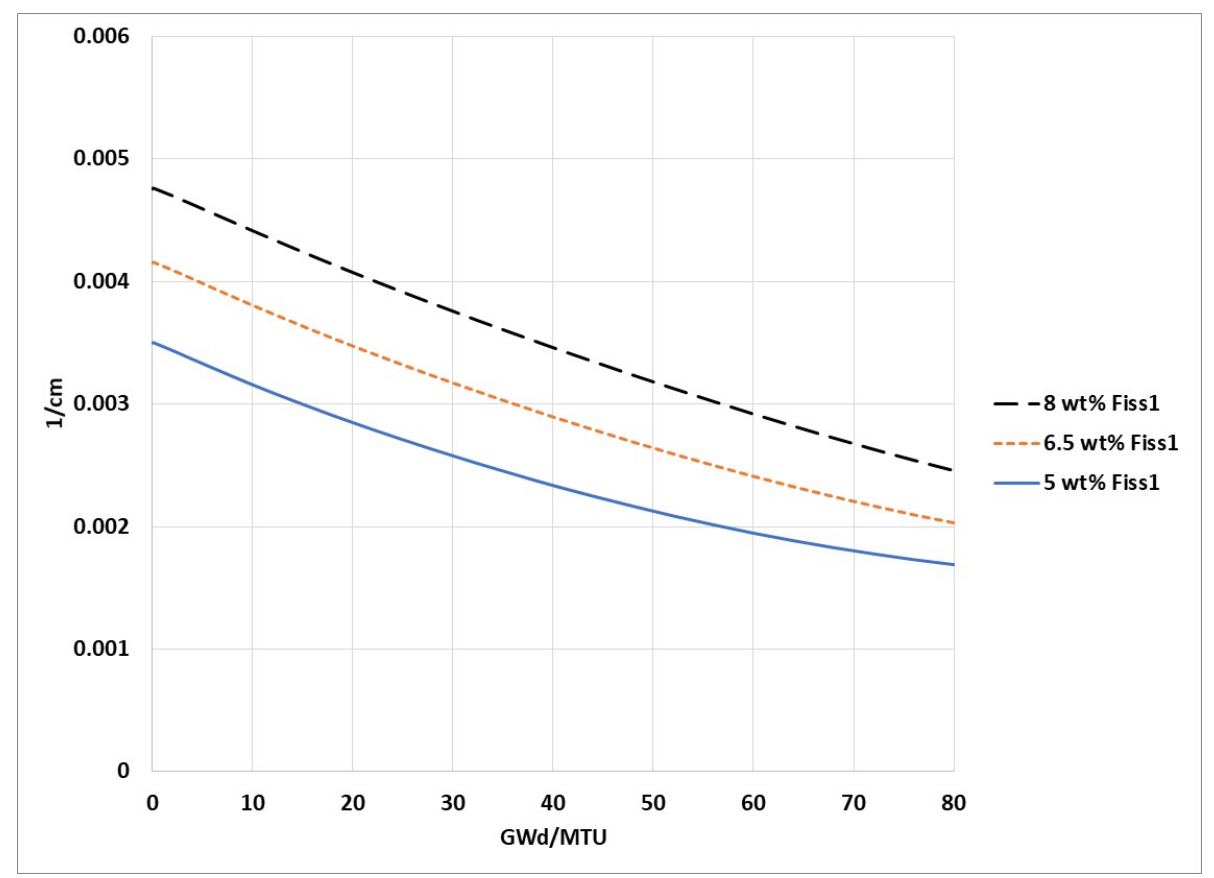

Figure 33. HFP fast fission cross section. 
The thermal removal cross section is largely a function of the thermal absorption cross section (Figure 38). As shown in Figure 34, the magnitude increases with enrichment due to the large ${ }^{235} \mathrm{U}$ thermal absorption cross section and decreases as fissile material depletes.

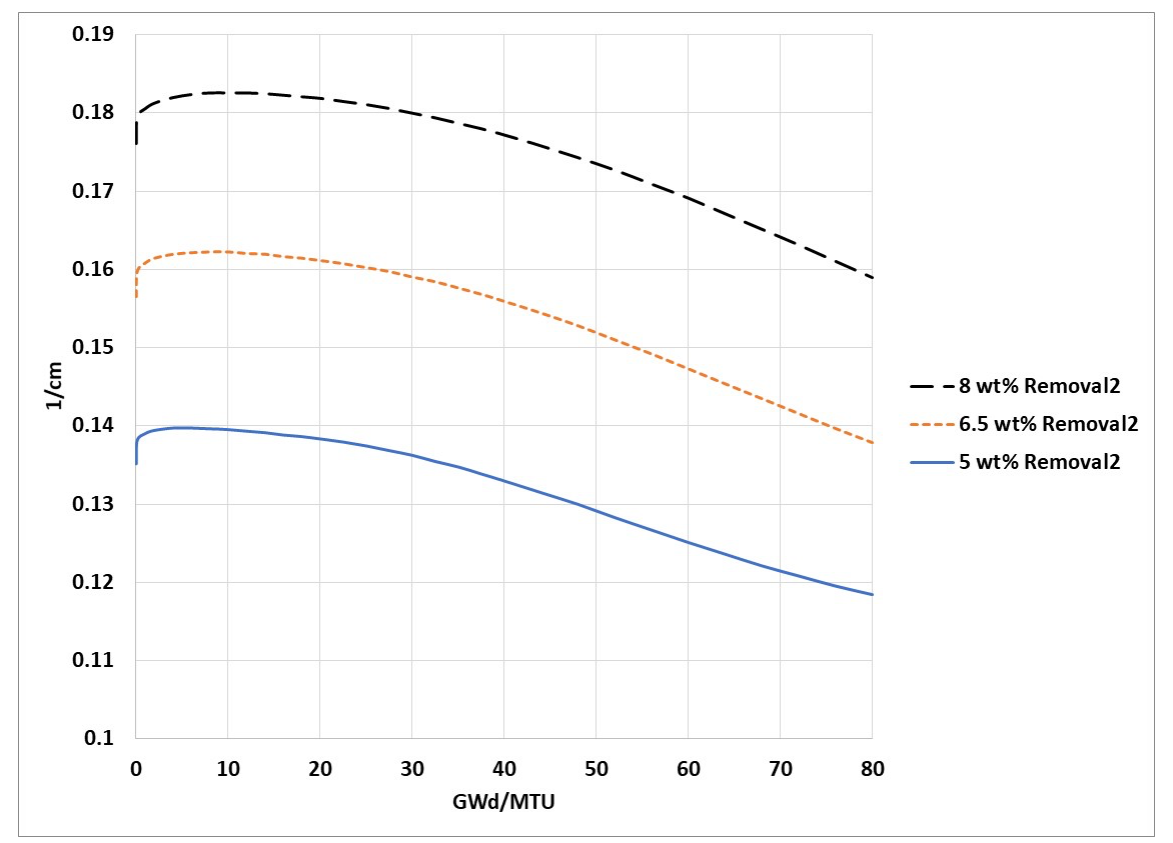

Figure 34. HFP thermal removal cross section.

The thermal absorption cross section increases with enrichment due to the large ${ }^{235} \mathrm{U}$ thermal absorption cross section. The trend with burnup shown in Figure 35 is a complex function of multiple factors: rapid buildup of xenon, buildup of saturating strong thermal absorber fission products (e.g. $\left.{ }^{149} \mathrm{Sm}\right)$, depletion of IFBA, depletion of ${ }^{235} \mathrm{U}$, buildup of fissile $\mathrm{Pu}$, and buildup of weak thermal absorber fission products.

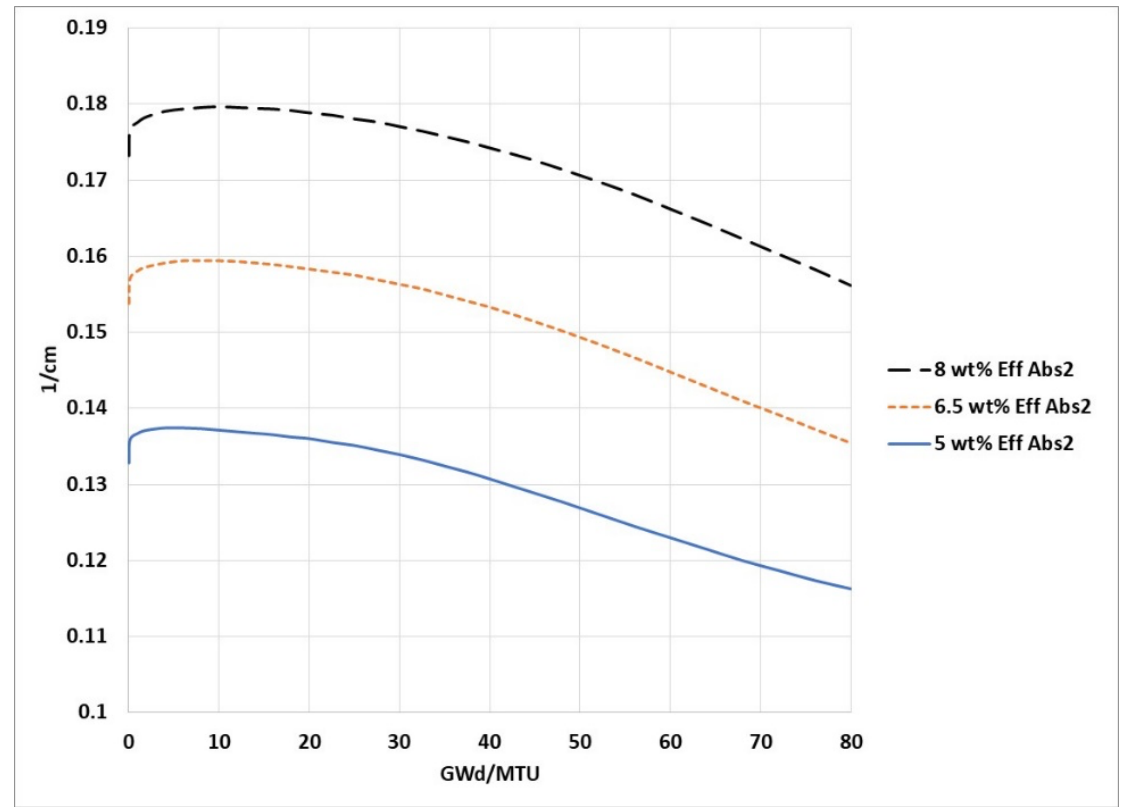

Figure 35. HFP thermal effective absorption cross section. 
The thermal fission cross section plotted in Figure 36 is primarily a function of fissile content (declines continuously with burnup) and thermal group spectrum changes. Increasing xenon near the beginning of the depletion hardens the thermal spectrum and reduces the thermal fission cross section. IFBA depletion has the opposite effect, which is visible in the $0-10 \mathrm{GWd} / \mathrm{MTU}$ burnup range.

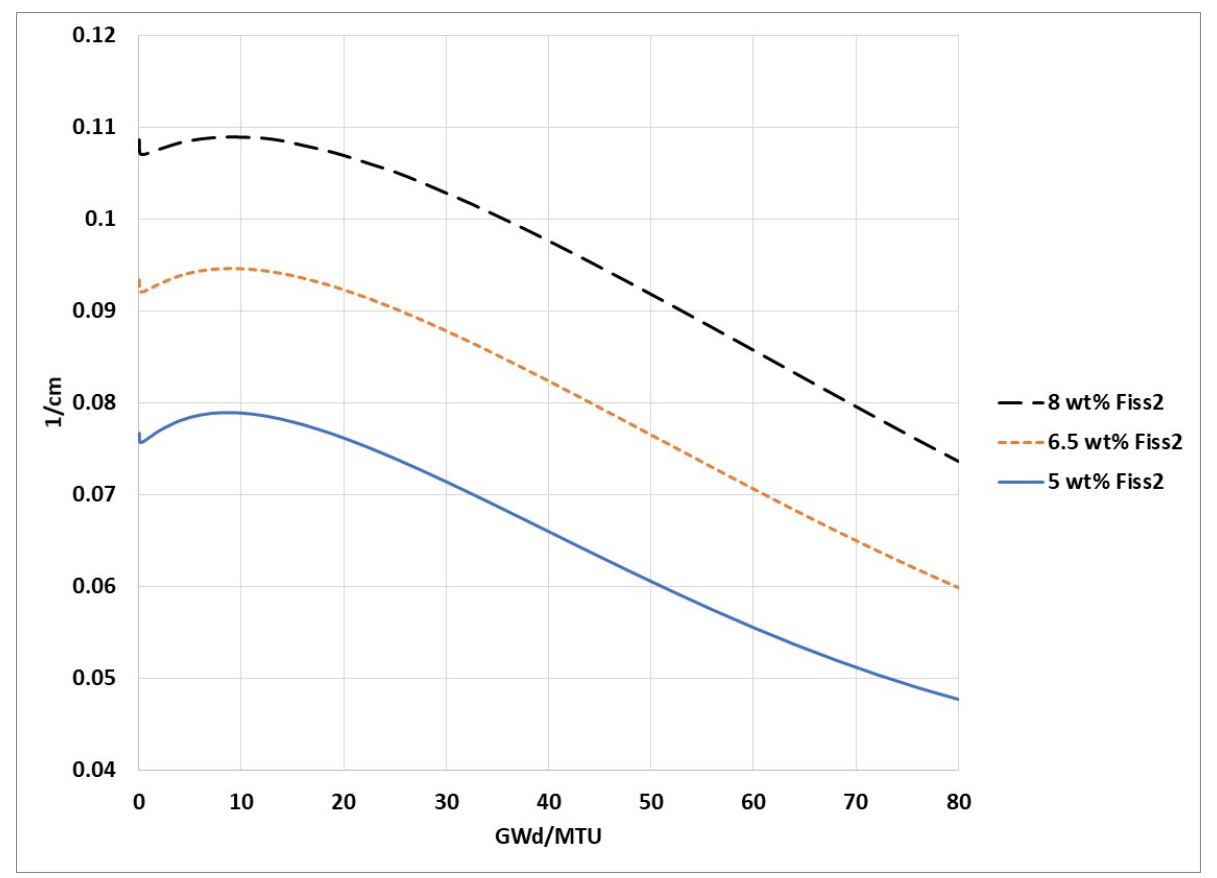

Figure 36. HFP thermal fission cross section.

\subsubsection{Kinetics Parameters}

Kinetics parameters include the effective delayed neutron fraction (unitless) and the delayed neutron decay constant $(1 / \mathrm{sec})$. 
The B-eff trend shown in Figure 37 is determined by the fraction of fissions occurring in different nuclides. The delayed neutron fraction is much lower for $\mathrm{Pu}$ fission than for $\mathrm{U}$ fission. Higher enrichment depletion results in a lower fraction of fissions in $\mathrm{Pu}$ (Figure 2) than the reference depletion at the same burnup, which results in a higher B-eff. Increased burnup in a higher enrichment core tends to offset the enrichment-only effect.

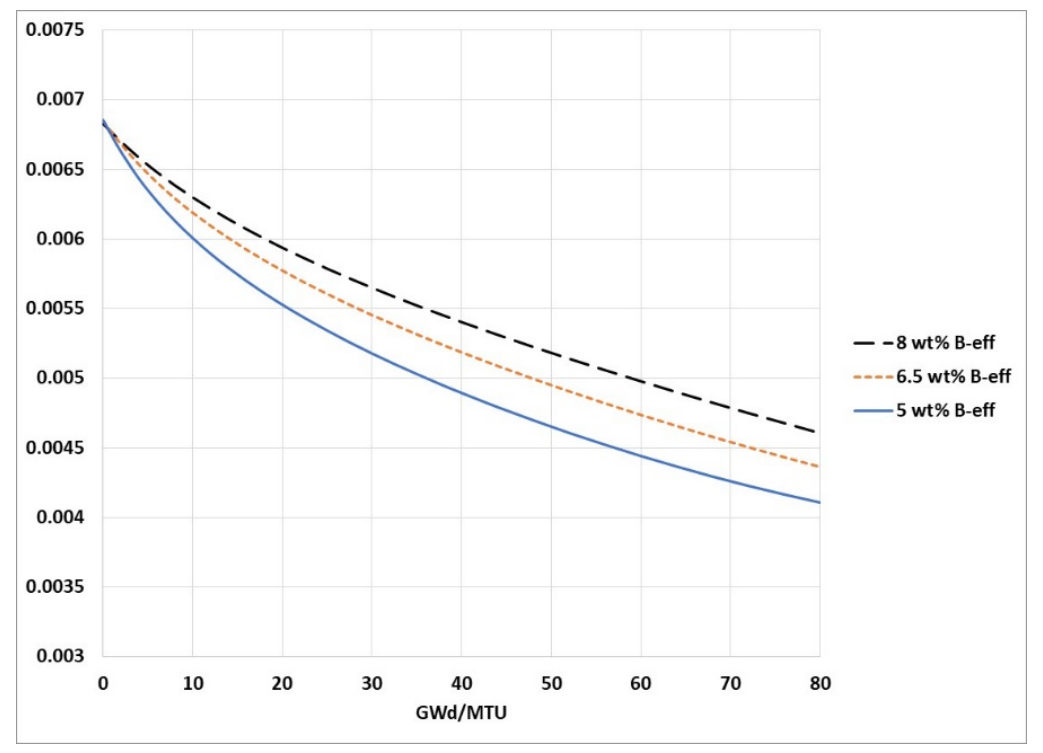

Figure 37. HFP effective delayed neutron fraction.

The effective delayed neutron decay constant (L-eff) depends on the population of delayed neutron precursors produced from fission. The trends in Figure 38 arise because different fissionable nuclides have different fission yields for delayed neutron precursors, which changes the aggregate delayed neutron decay constant. Variation of L-eff over the enrichment and burnup range is small ( $\sim 5 \%)$. L-eff decreases with increasing enrichment and increases with burnup over most of the burnup range. Increased burnup in a higher enrichment core tends to offset the enrichment-only effect.

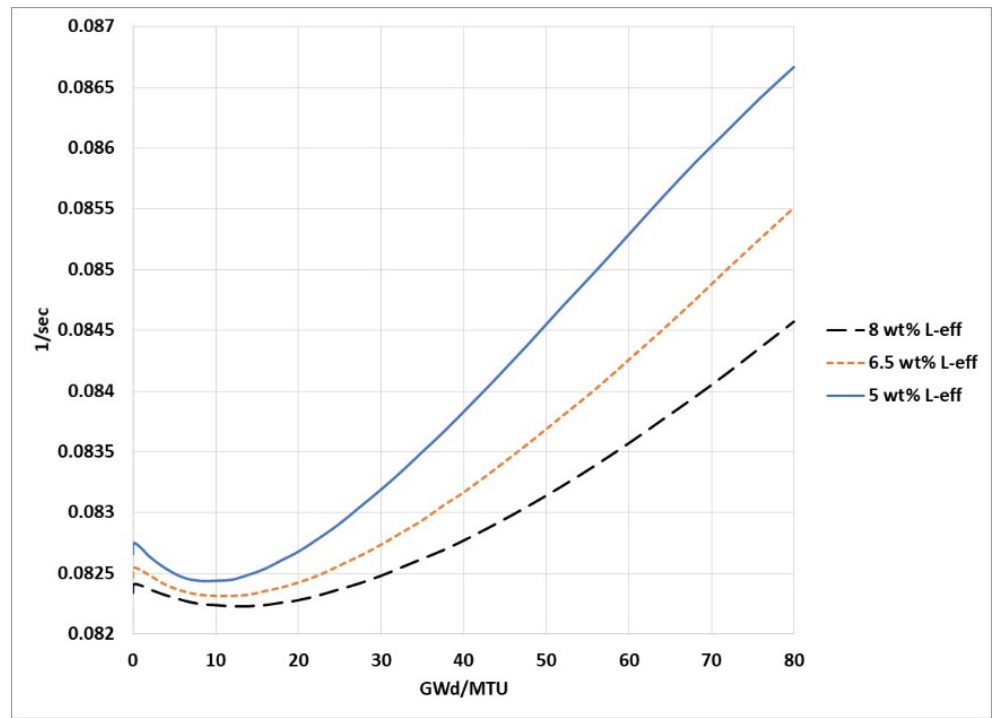

Figure 38. HFP effective delayed neutron decay constant. 


\section{SIMILARITY AND UNCERTAINTY}

\subsection{TSUNAMI SFP STORAGE SIMILARITY AND UNCERTAINTY}

The availability of applicable critical benchmark experiments for model validation will be assessed in another phase of this project.

To provide a limited preliminary look at the magnitude of similarity change resulting from increased burnup and enrichment, TSUNAMI-3D and TSUNAMI-IP were used to compare three depleted fuel assemblies (5 wt $\% 60 \mathrm{GWd} / \mathrm{MTU}, 8 \mathrm{wt} \% 84 \mathrm{GWd} / \mathrm{MTU}$, and $8 \mathrm{wt} \% 94 \mathrm{GWd} / \mathrm{MTU})$ stored in a representative SFP reflected rack cell. The $8 \mathrm{wt} \% 84 \mathrm{GWD} / \mathrm{MTU}$ case has approximately the same HFP in-core $\mathrm{k}_{\text {inf }}$ as the base case ( $\left.5 \mathrm{wt} \% 60 \mathrm{GWd} / \mathrm{MTU}\right)$. Furthermore, the $8 \mathrm{wt} \% 94 \mathrm{GWd} / \mathrm{MTU}$ case has approximately the same in-rack $\mathrm{k}_{\mathrm{inf}}$ as the base case. The calculation sequence is as follows.

1. A Polaris pin-cell depletion of a Westinghouse $17 \times 17$ fuel assembly to the discharge burnup was performed, followed by 5 days of decay.

2. A KENO-VI calculation was performed with a fuel assembly in an SFP rack cell under reflected boundary conditions. The SFP rack cases were simplified for this comparison:

a. All fuel pins in the fuel assembly had the inventory of the pin-cell after 5 days of decay.

b. No axial or radial burnup distribution was used.

c. The rack cell was a non-flux trap, neutron poison design. [6]

3. A TSUNAMI-3D case was run to create a sensitivity data file for each SFP case.

4. A TSUNAMI-IP case was run to calculate sensitivity coefficients describing the similarity of the two $8 \mathrm{wt} \%$ configurations to the $5 \mathrm{wt} \%$ base case. No identification of critical benchmark experiment applicability was attempted. However, if the similarity of the three cases were high, then computer code validation (including applicable experiment selection) would also be similar.

Figure 39 shows the KENO3D rendering of the rack cell. Rack cell materials and dimensions are shown in Table 3. SFP water was modeled at $293 \mathrm{~K}$ with a density of $1.0 \mathrm{~g} / \mathrm{cm}^{3}$ and no soluble boron. The TSUNAMI-3D/KENO-VI model included all isotopes from the ORIGEN decay run with number densities greater than $10^{-11}$ at $/ \mathrm{b}-\mathrm{cm}$ that also had neutron cross sections in the SCALE v7-252g library. A uniform mesh of $\sim 2 \mathrm{~cm} /$ mesh was used for the TSUNAMI-3D calculation. Neutron histories were sufficient to obtain one standard deviation convergence each of $25 \mathrm{pcm}$ for the forward calculation and $75 \mathrm{pcm}$ for the adjoint calculation. 

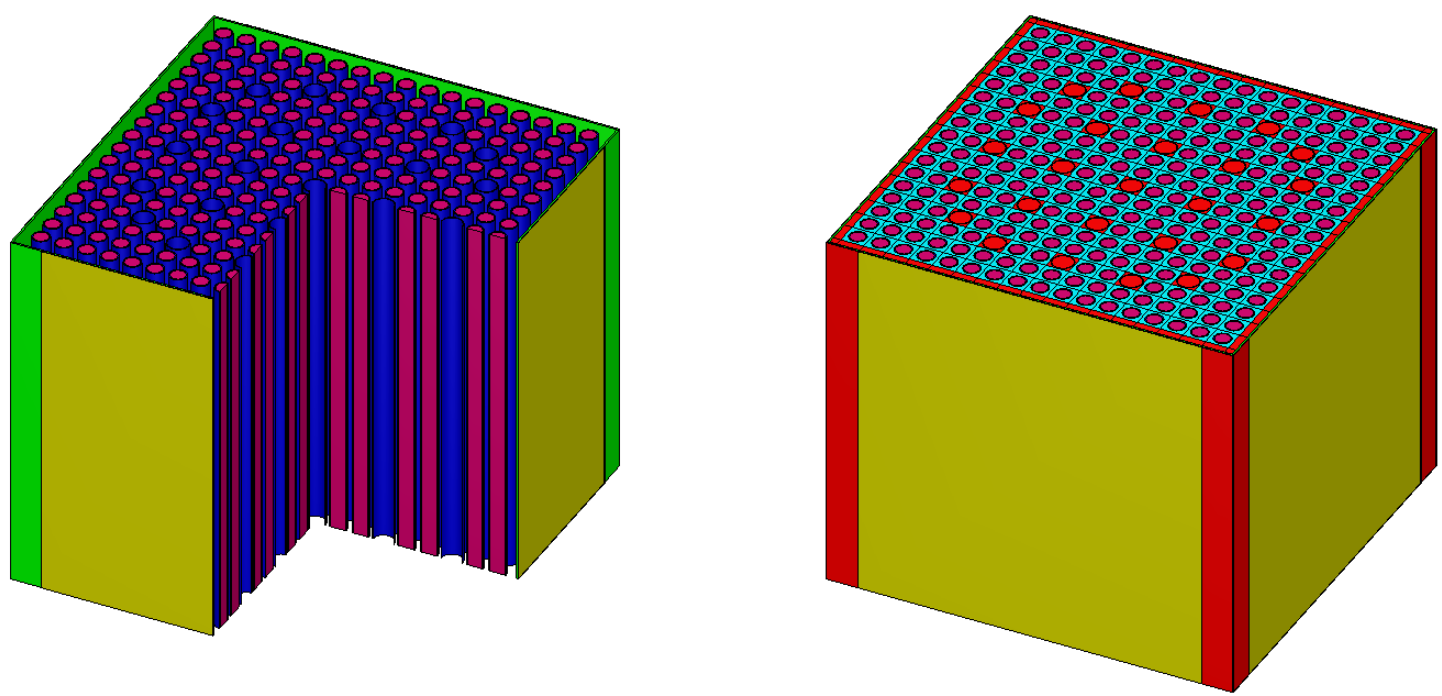

Figure 39. SFP rack cell model.

Table 3. SFP rack cell description [6]

\begin{tabular}{ll}
\hline Parameter & \multicolumn{1}{c}{ Dimension } \\
\hline Pitch & $22.5 \mathrm{~cm}$ \\
\hline Wall material & $304 \mathrm{SS}$ \\
\hline Wall thickness & $0.1 \mathrm{~cm}$ \\
\hline Poison sheet material & Borated aluminum \\
\hline Poison sheet thickness & $0.0625 \mathrm{~cm}$ \\
\hline${ }^{10} \mathrm{~B}$ areal density & $0.006 \mathrm{~g} / \mathrm{cm}^{3}$ \\
\hline
\end{tabular}

The primary quantity of interest from TSUNAMI is $c_{k}$. The closer that $c_{k}$ is to 1 , the more similar the applications are, and the more likely that a benchmark experiment appropriate for one model validation will also be appropriate for the others. TSUNAMI-3D also provides an estimate of $\mathrm{k}_{\text {inf }}$ uncertainty due to cross section uncertainty. Table 4 provides the results of the TSUNAMI calculations. Similarity is very high ( $\geq 0.983)$. Cross section uncertainty is nearly the same for all three models.

Table 4. TSUNAMI results

\begin{tabular}{lccc}
\hline \multicolumn{1}{c}{ Parameter } & $\begin{array}{c}\mathbf{5} \text { wt\% 60 } \\
\text { GWd/MTU }\end{array}$ & $\begin{array}{c}\mathbf{8} \mathbf{w t} \% \mathbf{8 4} \\
\text { GWd/MTU }\end{array}$ & $\begin{array}{c}\mathbf{8} \text { wt\% 94 } \\
\text { GWd/MTU }\end{array}$ \\
\hline Forward $\mathrm{k}_{\text {inf }}$ & 0.88541 & 0.92844 & 0.88360 \\
\hline Adjoint $\mathrm{k}_{\text {inf }}$ & 0.88513 & 0.92848 & 0.88404 \\
\hline Uncert, forward & 0.00024 & 0.00022 & 0.00024 \\
\hline EALF*, forward & 0.388 & 0.464 & 0.471 \\
\hline Uncert, adjoint & 0.00074 & 0.00074 & 0.00074 \\
\hline XS Uncert $(\% \Delta \mathrm{k} / \mathrm{k})$ & $\mathbf{0 . 5 3 3 \%}$ & $\mathbf{0 . 5 1 4 \%}$ & $\mathbf{0 . 5 5 2 \%}$ \\
\hline ck $_{\mathrm{k}}$ & & $\mathbf{0 . 9 8 5}$ & $\mathbf{0 . 9 8 3}$ \\
\hline
\end{tabular}

*Energy of the average lethargy of fission 


\subsection{SAMPLER/POLARIS DEPLETION UNCERTAINTY}

Uncertainty in $\mathrm{k}_{\text {inf }}$ due to cross section uncertainty can be calculated using the SCALE Sampler sequence in combination with Polaris. Sampler uses up to 1,000 perturbed cross section libraries to determine $\mathrm{k}_{\text {inf }}$ uncertainty for a Polaris model with a static fuel composition, or it performs a series of perturbed cross section depletions to capture the effect of cross section uncertainty on depleted fuel isotopic content.

Due to the level of computer resources required to perform hundreds of depletions, Sampler perturbed depletions were performed using a single pin-cell model, with the pin pitch increased $(1.32077 \mathrm{~cm})$ to account for guide tube, instrument tube, and assembly gap volume. This approximation preserves the fuel/water ratio from the full assembly model, but it ignores the effect of IFBA. However, because IFBA is fully depleted long before the lowest burnup of interest for HBU (60 GWd/MTU), this is an acceptable approximation. The results of these calculations provide the combined effect of cross section uncertainty on the $\mathrm{k}_{\text {inf }}$ calculation as well as the effect of cross section uncertainty on depleted fuel isotopic content.

Uncertainty ( $\mathrm{k}_{\text {inf }}$ standard deviation/unperturbed depletion $\mathrm{k}_{\text {inf }}$ ) as a function of burnup for a $5 \mathrm{wt} \%$ pin-cell and an $8 \mathrm{wt} \%$ pincell is shown in Figure 40. Uncertainty of the $8 \mathrm{wt} \%$ depletion is lower than the $5 \mathrm{wt} \%$ depletion after $20 \mathrm{GWd} / \mathrm{MTU}$. Uncertainty of $5 \mathrm{wt} \% 60 \mathrm{GWd} / \mathrm{MTU}$ and $8 \mathrm{wt} \% 84 \mathrm{GWd} / \mathrm{MTU}$ are essentially the same $(0.65 \% \Delta \mathrm{k} / \mathrm{k})$ and are only $\sim 13 \%$ larger than the cross section-only uncertainty of the SFP storage cases (Table 4). It is probable that uncertainty cancellation effects minimize the combined uncertainty of depletion inventory and cross sections. For example, if an absorber nuclide with large uncertainty is depleted with absorption cross sections perturbed high, the amount of that nuclide produced is lower (more lost to neutron absorption), which mitigates some of the $\mathrm{k}_{\text {inf }}$ uncertainty associated with that nuclide. Uncertainty is about $0.11 \% \Delta \mathrm{k} / \mathrm{k}$ higher at $80 \mathrm{GWd} / \mathrm{MTU}$ than at $60 \mathrm{GWd} / \mathrm{MTU}$.

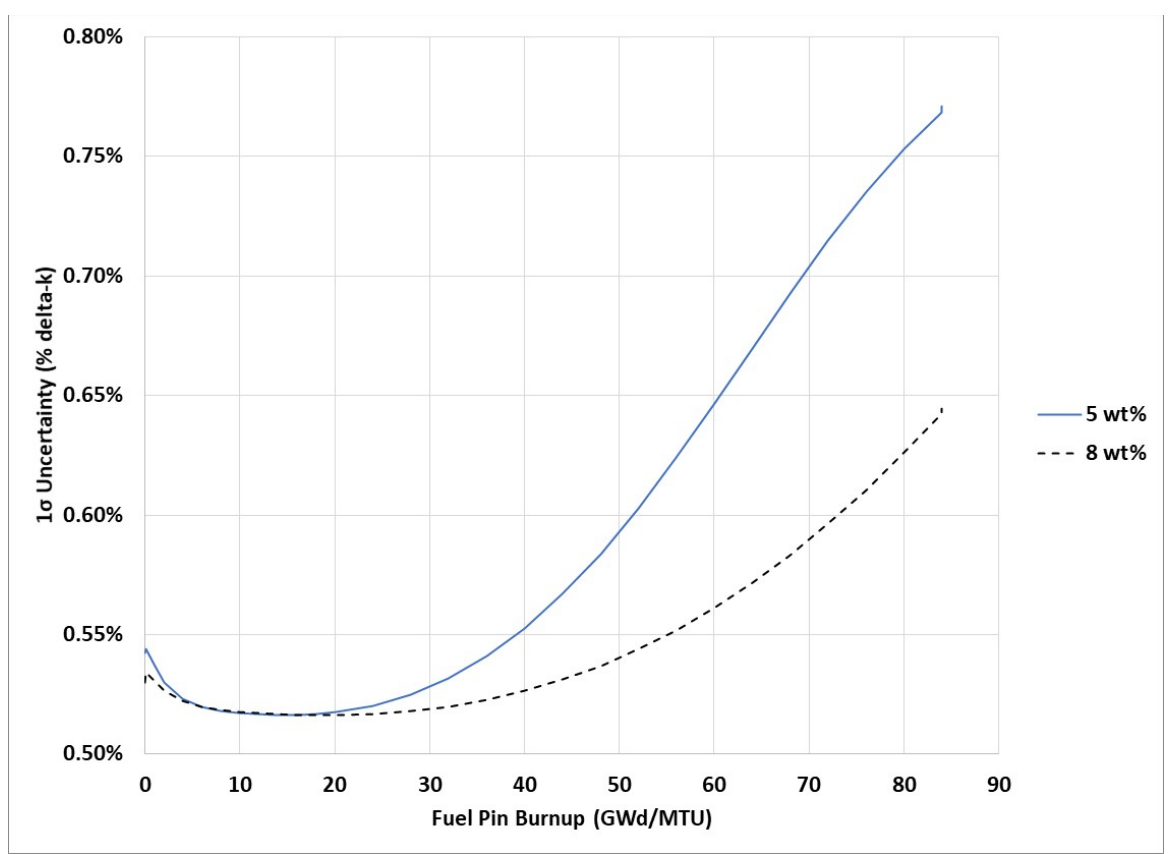

Figure 40. HFP pin-cell Polaris model perturbed depletion $k_{\text {inf }}$ uncertainty. 
Table 5 shows the Sampler/Polaris calculated number density uncertainty of 24 isotopes important to criticality. Values for the $8 \mathrm{wt} \%$ depletion are generally lower than those for the $5 \mathrm{wt} \%$ depletion. These values may also be useful as estimators of uncertainty for other quantities of interest where they are important, such as decay heat or activity. These cases use the SCALE v7-56g library.

Table 5. Sampler isotopic content uncertainty*

\begin{tabular}{lcc}
\hline Isotope & $\begin{array}{c}\mathbf{5} \mathbf{w t} \% \\
\mathbf{6 0} \mathbf{G W d} / \mathbf{M T U}\end{array}$ & $\begin{array}{c}\mathbf{8} \mathbf{w t} \% \\
\mathbf{8 4} \mathbf{G W d} / \mathbf{M T U}\end{array}$ \\
\hline${ }^{239} \mathrm{Pu}$ & $2.0 \%$ & $1.6 \%$ \\
${ }^{238} \mathrm{U}$ & $0.0 \%$ & $0.0 \%$ \\
${ }^{241} \mathrm{Pu}$ & $1.9 \%$ & $1.5 \%$ \\
${ }^{240} \mathrm{Pu}$ & $2.1 \%$ & $1.9 \%$ \\
${ }^{235} \mathrm{U}$ & $1.8 \%$ & $0.8 \%$ \\
${ }^{135} \mathrm{Xe}$ & $3.6 \%$ & $2.7 \%$ \\
${ }^{103} \mathrm{Rh}$ & $1.9 \%$ & $1.6 \%$ \\
${ }^{143} \mathrm{Nd}$ & $2.1 \%$ & $1.7 \%$ \\
${ }^{16} \mathrm{O}$ & $0.0 \%$ & $0.0 \%$ \\
${ }^{237} \mathrm{~Np}$ & $3.6 \%$ & $3.4 \%$ \\
${ }^{133} \mathrm{Cs}$ & $1.0 \%$ & $0.9 \%$ \\
${ }^{242} \mathrm{Pu}$ & $4.4 \%$ & $4.2 \%$ \\
${ }^{131} \mathrm{Xe}$ & $6.1 \%$ & $5.1 \%$ \\
${ }^{149} \mathrm{Sm}$ & $3.0 \%$ & $2.6 \%$ \\
${ }^{236} \mathrm{U}$ & $1.3 \%$ & $1.5 \%$ \\
${ }^{99} \mathrm{Tc}$ & $0.6 \%$ & $0.4 \%$ \\
${ }^{155} \mathrm{Eu}$ & $26.1 \%$ & $29.4 \%$ \\
${ }^{243} \mathrm{Am}$ & $8.9 \%$ & $9.8 \%$ \\
${ }^{154} \mathrm{Eu}$ & $7.8 \%$ & $7.1 \%$ \\
${ }^{153} \mathrm{Eu}$ & $3.6 \%$ & $3.2 \%$ \\
${ }^{151} \mathrm{Sm}$ & $3.9 \%$ & $3.8 \%$ \\
${ }^{152} \mathrm{Sm}$ & $3.1 \%$ & $2.9 \%$ \\
${ }^{145} \mathrm{Nd}$ & $1.8 \%$ & $1.5 \%$ \\
${ }^{147} \mathrm{Pm}$ & $2.8 \%$ & $2.5 \%$ \\
\hline
\end{tabular}

*Nuclides important to criticality (Section 4.3)

\subsection{NUCLIDE WORTH RANKING}

Another way to assess the similarity between 60 and $80 \mathrm{GWd} / \mathrm{MTU}$ is by a comparison of nuclide worth. The $5 \mathrm{wt} \%$ HFP pincell model described in Section 4.2 was used to calculate the reactivity change caused by reducing the at-power depletion number density of 194 different nuclides by $50 \%$, one at a time. The nuclides were then ranked by importance (absolute value of 50\% worth) for both burnups. At each burnup, the top 25 nuclides represent $\geq 93 \%$ of the total perturbation worth for all 194 nuclides, 115 of which had a calculated worth of at least $1 \mathrm{pcm}$.

Table 6 lists the top 25 nuclide rank and worth at $60 \mathrm{GWd} / \mathrm{MTU}$ and the comparative ranking at $80 \mathrm{GWd} / \mathrm{MTU}$. Only one nuclide dropped off the list at $80 \mathrm{GWd} / \mathrm{MTU}:{ }^{101} \mathrm{Ru}$, which was replaced by ${ }^{238} \mathrm{Pu}$. 
Table 6. Nuclide worth ranking (5 wt\% fuel)*

\begin{tabular}{lcccc}
\hline Nuclide & $\begin{array}{c}\text { 60 GWd/MTU } \\
\text { Rank }\end{array}$ & $\begin{array}{c}\mathbf{8 0} \mathbf{G W d} / \mathbf{M T U} \\
\text { Rank }\end{array}$ & $\begin{array}{c}\mathbf{6 0} \text { GWd/MTU } \\
\text { Worth (pcm) }\end{array}$ & $\begin{array}{c}\mathbf{8 0} \text { GWd/MTU } \\
\text { Worth (pcm) }\end{array}$ \\
\hline${ }^{239} \mathrm{Pu}$ & 1 & 1 & 9,668 & 12,351 \\
${ }^{238} \mathrm{U}$ & 2 & 2 & $-7,183$ & $-6,813$ \\
${ }^{235} \mathrm{U}$ & 3 & 5 & 5,032 & 2,799 \\
${ }^{241} \mathrm{Pu}$ & 4 & 3 & 3,942 & 5,476 \\
${ }^{240} \mathrm{Pu}$ & 5 & 4 & $-3,486$ & $-3,781$ \\
${ }^{135} \mathrm{Xe}$ & 6 & 6 & $-1,199$ & $-1,130$ \\
${ }^{103} \mathrm{Rh}$ & 7 & 7 & -801 & -921 \\
${ }^{16} \mathrm{O}$ & 8 & 9 & -777 & -794 \\
${ }^{143} \mathrm{Nd}$ & 9 & 8 & -769 & -873 \\
${ }^{237} \mathrm{~Np}$ & 10 & 10 & -493 & -615 \\
${ }^{149} \mathrm{Sm}$ & 11 & 14 & -442 & -426 \\
${ }^{133} \mathrm{Cs}$ & 12 & 11 & -437 & -523 \\
${ }^{131} \mathrm{Xe}$ & 13 & 13 & -434 & -476 \\
${ }^{236} \mathrm{U}$ & 14 & 15 & -432 & -417 \\
${ }^{242} \mathrm{Pu}$ & 15 & 12 & -377 & -520 \\
${ }^{99} \mathrm{Tc}$ & 16 & 16 & -341 & -413 \\
${ }^{151} \mathrm{Sm}$ & 17 & 21 & -297 & -343 \\
${ }^{155} \mathrm{Eu}$ & 18 & 17 & -294 & -404 \\
${ }^{154} \mathrm{Eu}$ & 19 & 19 & -285 & -393 \\
${ }^{153} \mathrm{Eu}$ & 20 & 20 & -284 & -362 \\
${ }^{152} \mathrm{Sm}$ & 21 & 22 & -284 & -326 \\
${ }^{147} \mathrm{Pm}$ & 22 & 25 & -243 & -225 \\
${ }^{145} \mathrm{Nd}$ & 23 & 23 & -229 & -276 \\
${ }^{243} \mathrm{Am}$ & 24 & 18 & -220 & -403 \\
${ }^{101} \mathrm{Ru}$ & 25 & 26 & -169 & -217 \\
\hline
\end{tabular}

*Positive values of reactivity $\left(1 / \mathrm{k}_{2}-1 / \mathrm{k}_{1}\right)$ indicate that increasing the nuclide increases $\mathrm{k}_{\text {inf. }}$. 


\section{ISOTOPIC INVENTORY}

Four burnup-enrichment combinations were evaluated for large changes in isotopic composition under the following assembly-average discharge conditions:

1. $60 \mathrm{GWd} / \mathrm{MTU}, 5 \mathrm{wt} \%$ - base case

2. $60 \mathrm{GWd} / \mathrm{MTU}, 8 \mathrm{wt} \%$ - extended enrichment

3. $80 \mathrm{GWd} / \mathrm{MTU}, 8 \mathrm{wt} \%$ - maximum burnup, extended enrichment

4. $80 \mathrm{GWd} / \mathrm{MTU}, 6.5 \mathrm{wt} \%$ - maximum burnup, $6.5 \mathrm{wt} \%$ enrichment

$80 \mathrm{GWD} / \mathrm{MTU}$ burnup cases at $5 \mathrm{wt} \%$ are impractical from a reactivity standpoint (see Figure 5 ) and thus were not evaluated.

Most of the analysis in this section will compare these four cases. The tables below present various metrics using the comparison combinations in Table 7 . These cases used the same 104 IFBA W17×17 geometry used in the previous section of this report. The difference here is that soluble boron was assumed at 1,000 ppm. While this approximation may affect the isotopics to some extent, the general implications of extending burnup and enrichment are of interest in this section-not precise predictions. Polaris was used to perform the depletion with 27 depletion steps to $80 \mathrm{GWd} / \mathrm{MTU}$. The assembly was depleted at a specific power of $40 \mathrm{MW} / \mathrm{MTU}$ using a 56-group cross section library. ORIGEN was used to decay isotopes from various burnups to the cooling times.

Table 7. Layout of tables for isotopic composition comparisons

\begin{tabular}{|c|c|}
\hline 3\% enrichment increase & 20 GWd/MTU burnup increase \\
$5 \mathrm{wt} \%(\mathrm{ref}) \rightarrow 8$ at $60 \mathrm{GWd} / \mathrm{MTU}$ & $5 \mathrm{w} \%$ at $60 \mathrm{GWd} / \mathrm{MTU}(\mathrm{ref}) \rightarrow 80$ at $8 \mathrm{wt} \%$ \\
\hline $\mathbf{2 0} \mathbf{G W d} /$ MTU burnup and & $\mathbf{2 0 ~ G W d} /$ MTU burnup and \\
$\mathbf{1 . 5 \%}$ enrichment increase & $\mathbf{3 \%}$ enrichment increase \\
$5 \mathrm{wt} \%$ at $60 \mathrm{GWd} / \mathrm{MTU}(\mathrm{ref}) \rightarrow 6.5$ at 80 & $5 \mathrm{wt} \%$ at $60 \mathrm{GWd} / \mathrm{MTU}(\mathrm{ref}) \rightarrow 8$ at 80 \\
\hline
\end{tabular}

Five decay times were evaluated for each case in this section. The reasons for selections of the various time points are listed below:

- 0 seconds: provides a reference value for other time points

- 30 min: captures possible impacts of isotopics on core cooling events (e.g., LOCA)

- 5 days: captures possible impacts of isotopics during refueling outage/discharge

- 25 days: captures possible impacts of isotopics at the end of refueling outage/discharge

- 500 days: captures possible impacts of isotopics on early long-term storage

Isotopes are ranked by the root mean squared (RMS) value of the isotope's percent total contribution to some quantity such as activity or decay heat given by

$$
R M S_{i}=\sqrt{\sum_{n}\left(\frac{a_{i n}-b_{i n}}{b_{n}}\right)^{2}}
$$

where $a_{\text {in }}$ and $b_{\text {in }}$ are the values for isotope $i$ being compared at time point $n$, with $b_{n}$ being the total of all isotopes at time point $n$. The timepoint of 0 seconds of decay is not included in calculating any of the rankings. 


\subsection{NEUTRON EXPOSURE}

The amount of neutron exposure often drives isotopic behavior. Before examining the individual isotopes, the flux is shown as a function of burnup for each case evaluated in Figure 41. It is clearly seen that reduced enrichment is associated with increased flux and neutron exposure because increased flux is necessary to maintain power with reduced enrichment. Increased neutron exposure should increase abundances of neutron absorption products like the higher actinides and plutonium, as well as isotopes that preferentially result from plutonium fission. Likewise, because plutonium is producing a larger fraction of the power in lower enriched fuel, fission products preferentially produced by uranium fission would decrease in abundance. Increases in burnup are also expected to produce the same trends, again due to increased neutron exposure. Notably, these trends may not hold when comparing assemblies under different conditions such as assemblies with different control rod positions or assemblies with different soluble boron concentrations.

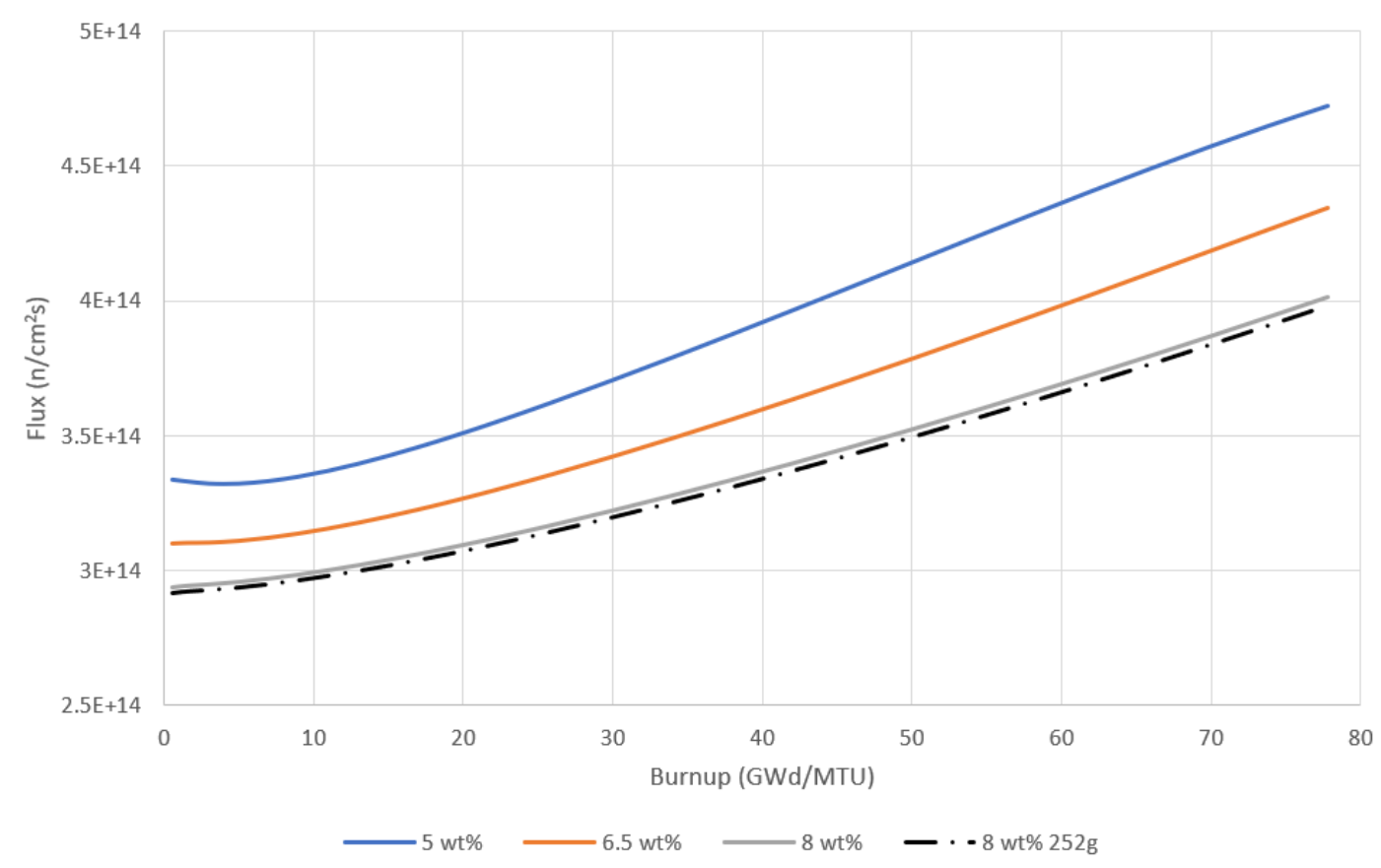

Figure 41. Flux magnitude for cases evaluated.

\subsection{DECAY HEAT TRENDS}

It is common knowledge that decay heat immediately after shutdown is primarily due to short-lived isotopes decaying away. The concentration of these isotopes is almost completely dependent on reactor operating power at the end of the cycle. Later, as the short-lived isotopes decay away, the decay heat depends more upon operating history and long-lived isotopes. After longer time periods, when actinides become a more dominant component of the decay heat, assembly decay heat begins to result from assembly enrichment. This is seen in Figure 42, which plots decay heat vs time for the four burnupenrichment combinations evaluated. All decay heats are relatively close at short cooling times, and they just begin to diverge a month after operations cease. 


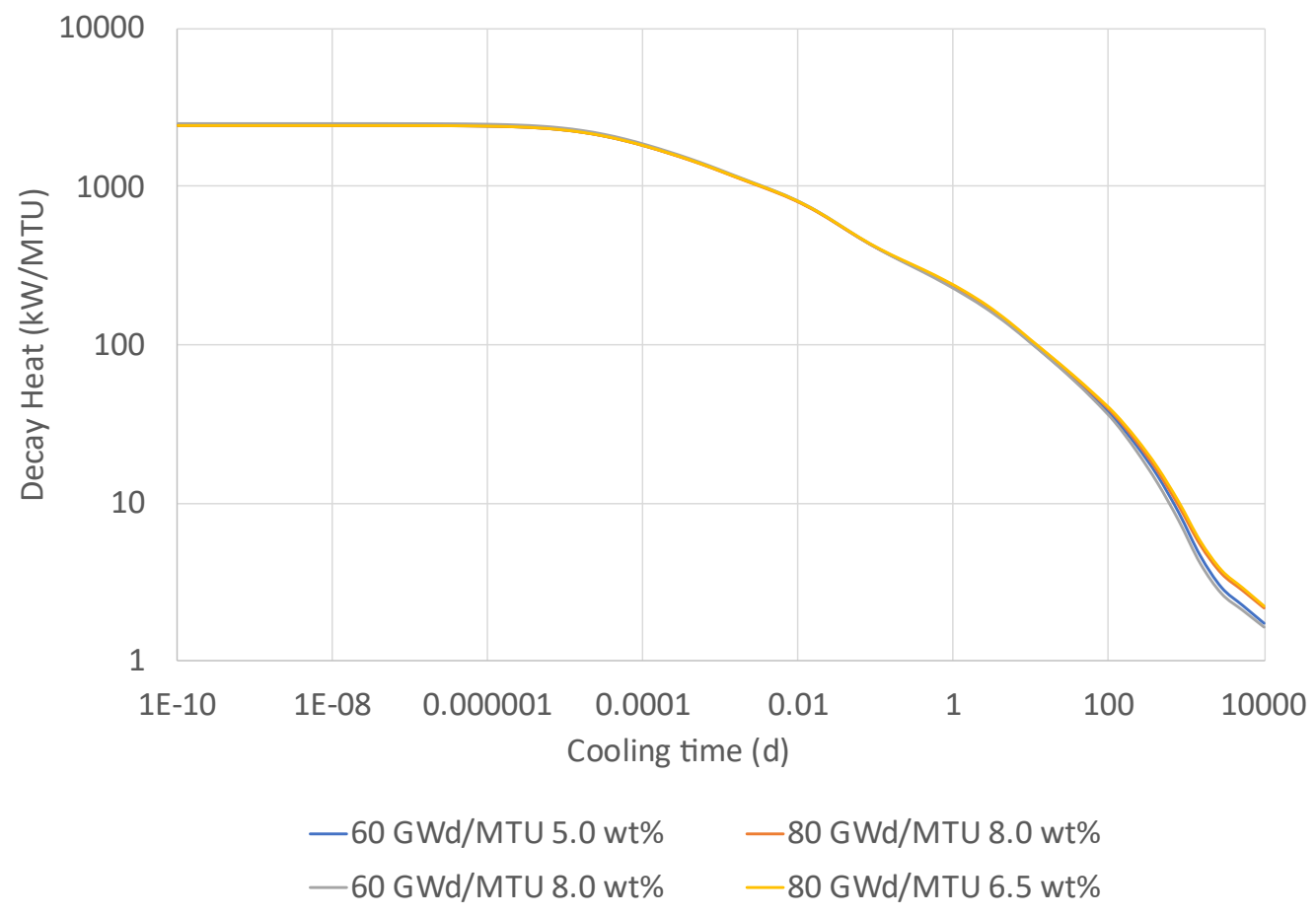

Figure 42. Decay heat as a function of cooling time.

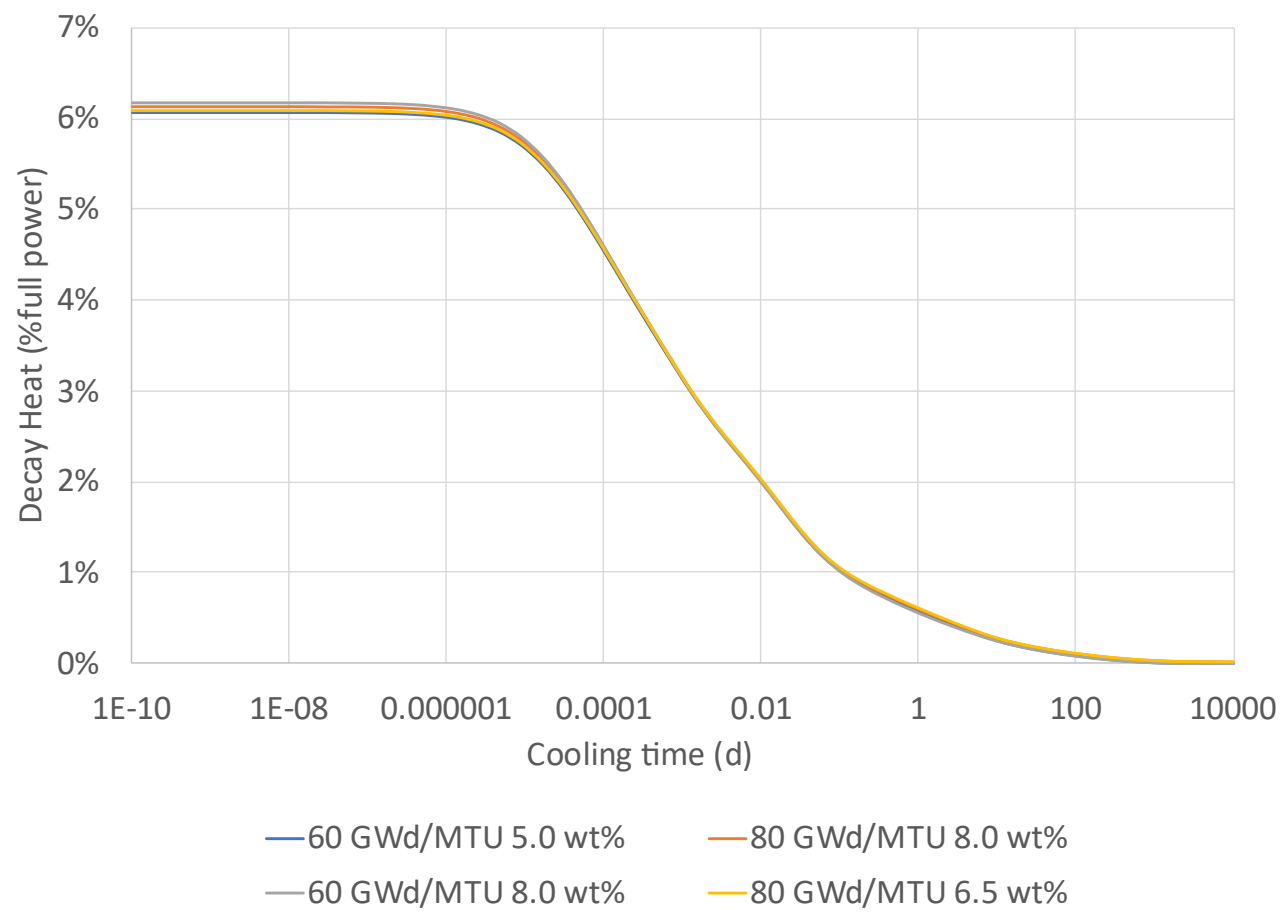

Figure 43. Decay heat as a percentage of power vs cooling time. 
Decay heat is shown as the percentage of full operating power in Figure 43. At 0 seconds after shutdown, decay heat is 6.0 to $6.2 \%$ of operating power for all cases. To better capture the relative behaviors of the decay heat curves, all curves were compared to the reference $60 \mathrm{GWd} / \mathrm{MTU} 5 \mathrm{wt} \%$ case shown in Figure 44. Percent difference at each time was calculated as

$$
\frac{Q(t)}{Q_{r e f}(t)}-1
$$

where $Q(t)$ is the decay heat as a function of time, and $Q_{r e f}(t)$ is the decay heat for the reference case. As expected, lower enrichments at the same burnup produced higher decay heats, and higher burnups at the same enrichment produced higher decay heats. All cases diverged at later time points and followed smooth trends with the exception of the $8 \mathrm{wt} \%$ cases, which showed non-monotonic behavior. In summary, shortly after reactor shutdown, burnup and enrichment have less influence on decay heat than operating power. As the short-lived fission products decay away, longer lived fission and activation products begin to contribute much more to decay heat, and decay heat begins to depend more on burnup and enrichment. Notably, no single isotope changed decay heat by more than $10 \%$ in any comparison evaluated. Decay heat generally increased at later time points when enrichment decreased or burnup increased. This is consistent with the behavior of existing nuclear fuel. To understand the long-time behavior in absolute terms, the absolute $\mathrm{kW} / \mathrm{MTU}$ from the reference case is shown in Figure 45. The absolute difference rapidly decreases with time and is less than $2 \mathrm{~kW} / \mathrm{MTU}$ for times longer than a few days.

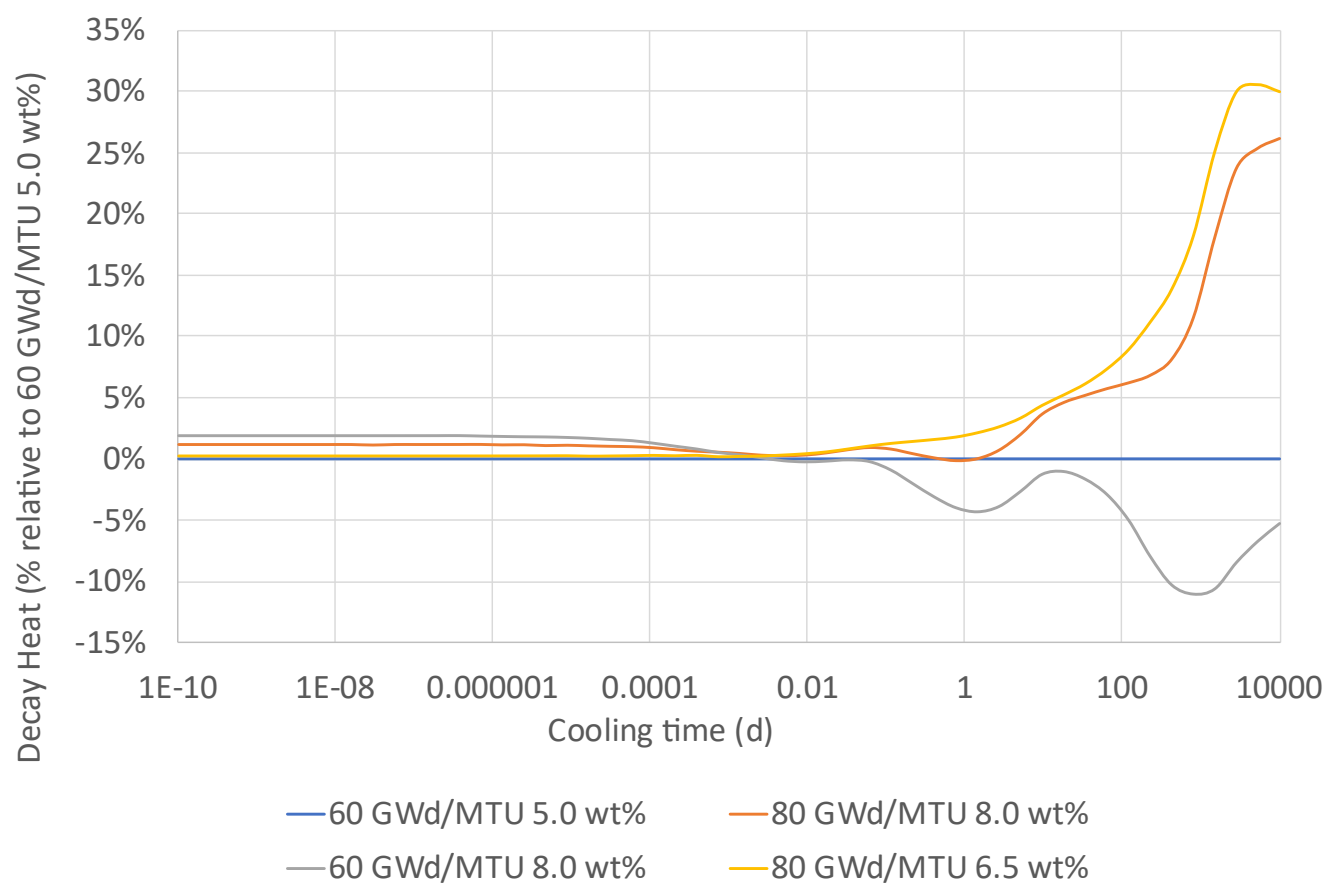

Figure 44. Decay heat relative difference from $60 \mathrm{GWd} / \mathrm{MTU} 5 \mathrm{wt} \%$ case. 


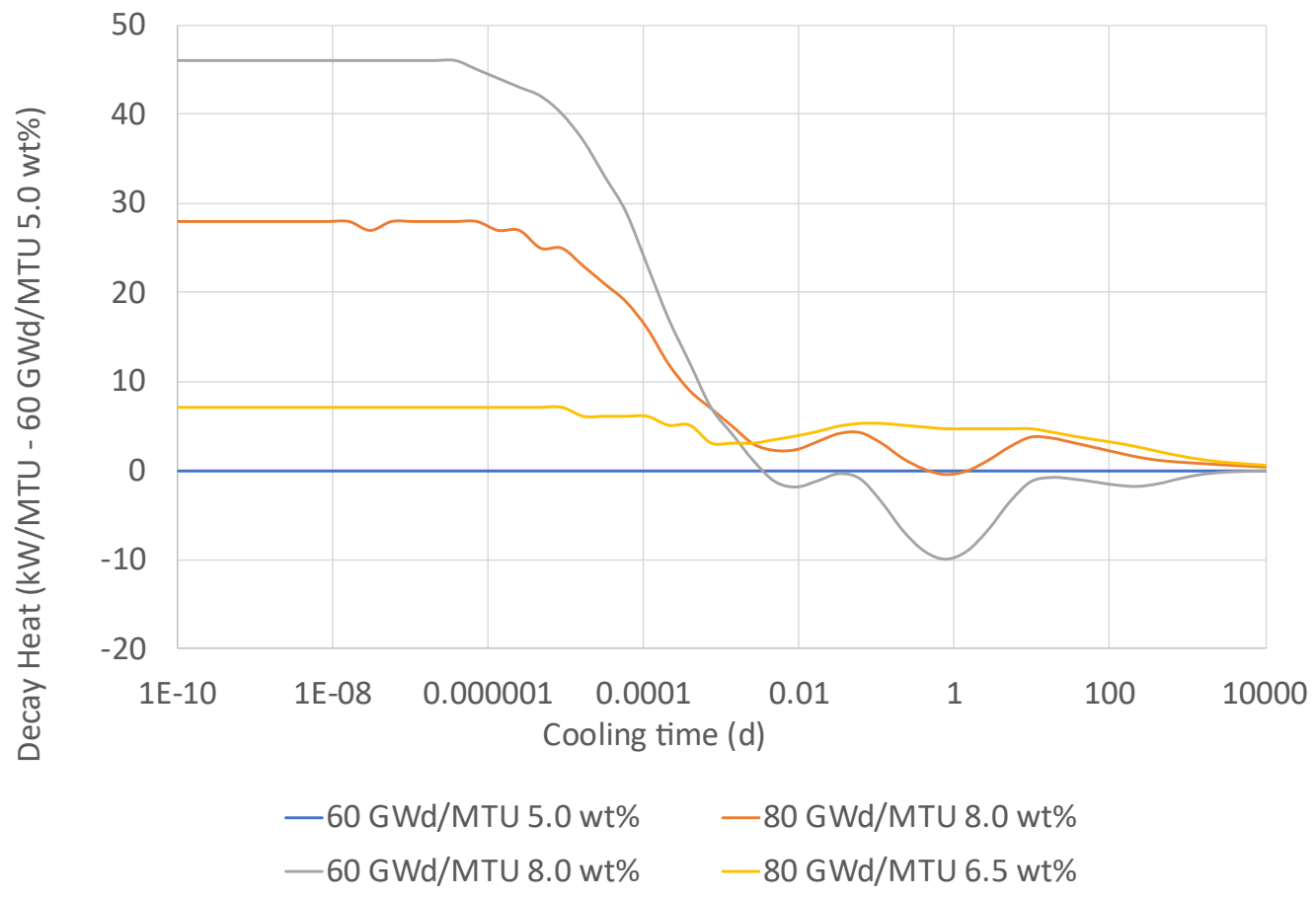

Figure 45. Decay heat absolute difference from $60 \mathrm{GWd} / \mathrm{MTU} 5 \mathrm{wt} \%$ case.

\subsection{DECAY HEAT ISOTOPES RANKED BY RELATIVE CHANGE}

Table 8 compares HBU and EE isotopics of various cases. The values are the difference in decay heat for the isotope expressed as a percentage of total decay heat of the reference case. Relative differences in decay heat production are color coded, with blue indicating a decreasing decay heat from baseline, and red indicating an increasing decay heat from baseline. The relative differences are computed as follows:

$$
\frac{Q_{i}-Q_{r e f, i}}{Q_{r e f}}-1
$$

where $Q_{i}$ is the decay heat for isotope $i$ for the HBU or EE case listed in the table heading. The second case specified in each heading is the reference case and is denoted in the above expression as ref. $Q_{r e f}$ is the total decay heat for the reference case at the timepoint in question. The expression yields a value indicating the amount of change introduced by each isotope relative to the total decay heat of the reference case. The top 15 isotopes are presented according to the RMS ranking introduced in Eq. (1). The row labeled Subtotal is the total relative change produced by those isotopes, and the row labeled Total is the total difference for the two cases. Note that shortly after shutdown, many more isotopes than those listed contribute to decay heat, so the difference caused by the top 15 contributors by RMS ranking (subtotal) does not coincide with the total. At longer decay times, as short-lived fission products decay away, fewer isotopes are responsible for the decay heat, so the top 15 isotopes by RMS ranking correctly account for the majority of differences. For example, at 500 days with increased enrichment only (Table 8, upper left comparison), the difference is driven by six isotopes - ${ }^{106} \mathrm{Rh},{ }^{134} \mathrm{Cs},{ }^{144} \mathrm{Pr},{ }^{244} \mathrm{Cm},{ }^{242} \mathrm{Cm}$, and ${ }^{90} \mathrm{Y}$ - and the top 15 isotopes across all times (subtotal) coincide with the total of $-10 \%$ change. 
Table 8. Contributions of each isotope to total percent change in decay heat

\begin{tabular}{|c|c|c|c|c|c|c|c|c|c|c|c|}
\hline \multicolumn{6}{|c|}{$\begin{array}{c}\text { 3\% enrichment increase } \\
5 \mathrm{wt} \% \text { (ref) } \rightarrow 8 \text { at } 60 \mathrm{GWd} / \mathrm{MTU}\end{array}$} & \multicolumn{6}{|c|}{$\begin{array}{c}20 \mathrm{GWd} / \mathrm{MTU} \text { burnup increase } \\
60 \mathrm{GWd} / \mathrm{MTU} \text { (ref) } \rightarrow 80 \text { for } 8 \mathrm{w} \%\end{array}$} \\
\hline \begin{tabular}{|l|} 
Isotope \\
\end{tabular} & $0 \mathrm{~s}$ & $30 \mathrm{~min}$ & 5 days & 25 days & 500 days & Isotope & $0 \mathrm{~s}$ & $30 \mathrm{~min}$ & 5 days & 25 days & 500 days \\
\hline${ }^{106} \mathrm{Rh}$ & $-0.1 \%$ & $-0.3 \%$ & $-1.6 \%$ & $-2.9 \%$ & $-6.8 \%$ & ${ }^{134} \mathrm{Cs}$ & $0.1 \%$ & $0.3 \%$ & $1.3 \%$ & $2.4 \%$ & $9.7 \%$ \\
\hline${ }^{134} \mathrm{Cs}$ & $0.0 \%$ & $-0.1 \%$ & $-0.4 \%$ & $-0.9 \%$ & $-3.1 \%$ & ${ }^{106} \mathrm{Rh}$ & $0.1 \%$ & $0.3 \%$ & $1.3 \%$ & $2.4 \%$ & $6.2 \%$ \\
\hline${ }^{239} \mathrm{~Np}$ & $-0.5 \%$ & $-1.9 \%$ & $-2.1 \%$ & $0.0 \%$ & $0.0 \%$ & ${ }^{242} \mathrm{Cm}$ & $0.1 \%$ & $0.3 \%$ & $1.7 \%$ & $3.0 \%$ & $2.5 \%$ \\
\hline${ }^{144} \mathrm{Pr}$ & $0.0 \%$ & $0.1 \%$ & $0.6 \%$ & $1.2 \%$ & $2.0 \%$ & ${ }^{244} \mathrm{Cm}$ & $0.0 \%$ & $0.1 \%$ & $0.3 \%$ & $0.5 \%$ & $3.2 \%$ \\
\hline${ }^{244} \mathrm{Cm}$ & $0.0 \%$ & $0.0 \%$ & $-0.2 \%$ & $-0.4 \%$ & $-2.1 \%$ & ${ }^{238} \mathrm{Pu}$ & $0.0 \%$ & $0.0 \%$ & $0.2 \%$ & $0.4 \%$ & $2.4 \%$ \\
\hline${ }^{242} \mathrm{Cm}$ & $0.0 \%$ & $-0.2 \%$ & $-0.8 \%$ & $-1.5 \%$ & $-1.1 \%$ & $137 \mathrm{~m} \mathrm{Ba}$ & $0.0 \%$ & $0.0 \%$ & $0.2 \%$ & $0.3 \%$ & $1.9 \%$ \\
\hline${ }^{156} \mathrm{Eu}$ & $-0.1 \%$ & $-0.3 \%$ & $-1.0 \%$ & $-0.8 \%$ & $0.0 \%$ & ${ }^{90} \mathrm{Y}$ & $0.0 \%$ & $0.0 \%$ & $0.1 \%$ & $0.3 \%$ & $1.6 \%$ \\
\hline${ }^{95} \mathrm{Nb}$ & $0.0 \%$ & $0.1 \%$ & $0.6 \%$ & $1.1 \%$ & $0.1 \%$ & ${ }^{156} \mathrm{Eu}$ & $0.1 \%$ & $0.3 \%$ & $1.1 \%$ & $0.8 \%$ & $0.0 \%$ \\
\hline${ }^{91} \mathrm{Y}$ & $0.0 \%$ & $0.1 \%$ & $0.6 \%$ & $1.0 \%$ & $0.0 \%$ & ${ }^{239} \mathrm{~Np}$ & $0.2 \%$ & $0.8 \%$ & $0.9 \%$ & $0.0 \%$ & $0.0 \%$ \\
\hline${ }^{95} \mathrm{Zr}$ & $0.0 \%$ & $0.1 \%$ & $0.6 \%$ & $0.9 \%$ & $0.0 \%$ & ${ }^{144} \mathrm{Pr}$ & $0.0 \%$ & $-0.1 \%$ & $-0.3 \%$ & $-0.5 \%$ & $-1.0 \%$ \\
\hline${ }^{239} \mathrm{U}$ & $-0.6 \%$ & $-0.9 \%$ & $0.0 \%$ & $0.0 \%$ & $0.0 \%$ & ${ }^{95} \mathrm{Nb}$ & $0.0 \%$ & $-0.1 \%$ & $-0.4 \%$ & $-0.7 \%$ & $0.0 \%$ \\
\hline${ }^{140} \mathrm{La}$ & $0.0 \%$ & $0.1 \%$ & $0.8 \%$ & $0.6 \%$ & $0.0 \%$ & ${ }^{91} \mathrm{Y}$ & $0.0 \%$ & $-0.1 \%$ & $-0.4 \%$ & $-0.6 \%$ & $0.0 \%$ \\
\hline${ }^{89} \mathrm{Sr}$ & $0.0 \%$ & $0.1 \%$ & $0.5 \%$ & $0.8 \%$ & $0.0 \%$ & ${ }^{95} \mathrm{Zr}$ & $0.0 \%$ & $-0.1 \%$ & $-0.4 \%$ & $-0.6 \%$ & $0.0 \%$ \\
\hline${ }^{103} \mathrm{Ru}$ & $0.0 \%$ & $-0.1 \%$ & $-0.5 \%$ & $-0.7 \%$ & $0.0 \%$ & ${ }^{140} \mathrm{La}$ & $0.0 \%$ & $-0.1 \%$ & $-0.5 \%$ & $-0.4 \%$ & $0.0 \%$ \\
\hline${ }^{90} \mathrm{Y}$ & $0.0 \%$ & $0.0 \%$ & $0.1 \%$ & $0.1 \%$ & $0.8 \%$ & ${ }^{89} \mathrm{Sr}$ & $0.0 \%$ & $-0.1 \%$ & $-0.3 \%$ & $-0.5 \%$ & $0.0 \%$ \\
\hline Subtotal & $-1.2 \%$ & $-3.0 \%$ & $-2.8 \%$ & $-1.5 \%$ & $-10.1 \%$ & Subtotal & $0.4 \%$ & $1.6 \%$ & $4.7 \%$ & $7.0 \%$ & $26.4 \%$ \\
\hline Total & $1.9 \%$ & $-0.1 \%$ & $-2.6 \%$ & $-1.1 \%$ & $-10.3 \%$ & $\mathbf{T}$ & $-0.9 \%$ & $0.8 \%$ & $6.0 \%$ & $7.9 \%$ & $8.1 \%$ \\
\hline \multicolumn{6}{|c|}{$\begin{array}{c}20 \mathrm{GWd} / \mathrm{MTU} \text { burnup and } \\
\mathbf{1 . 5 \%} \text { enrichment increase } \\
\mathrm{wt} \% \text { at } 60 \mathrm{GWd} / \mathrm{MTU}(\text { ref }) \rightarrow 6.5\end{array}$} & \multicolumn{6}{|c|}{$\begin{array}{l}20 \text { GWd/MTU burnup and } \\
3 \% \text { enrichment increase }\end{array}$} \\
\hline Isotope & $0 \mathrm{~s}$ & 30 min & 5 days & 25 days & 500 days & Isotope & $0 \mathrm{~s}$ & 30 min & 5 days & 25 days & 500 days \\
\hline${ }^{134} \mathrm{Cs}$ & $0.1 \%$ & $0.2 \%$ & $1.1 \%$ & $2.1 \%$ & $7.6 \%$ & ${ }^{134} \mathrm{Cs}$ & $0.0 \%$ & $0.2 \%$ & $0.8 \%$ & $1.6 \%$ & $5.7 \%$ \\
\hline${ }^{244} \mathrm{Cm}$ & $0.0 \%$ & $0.1 \%$ & $0.3 \%$ & $0.5 \%$ & $2.8 \%$ & 90Y & $0.0 \%$ & $0.0 \%$ & $0.2 \%$ & $0.4 \%$ & $2.2 \%$ \\
\hline${ }^{242} \mathrm{Cm}$ & $0.1 \%$ & $0.2 \%$ & $1.1 \%$ & $2.1 \%$ & $1.5 \%$ & ${ }^{242} \mathrm{Cm}$ & $0.0 \%$ & $0.2 \%$ & $0.8 \%$ & $1.5 \%$ & $1.1 \%$ \\
\hline${ }^{106} \mathrm{Rh}$ & $0.0 \%$ & $0.1 \%$ & $0.5 \%$ & $1.0 \%$ & $2.3 \%$ & ${ }^{238} \mathrm{Pu}$ & $0.0 \%$ & $0.0 \%$ & $0.2 \%$ & $0.3 \%$ & $1.7 \%$ \\
\hline${ }^{238} \mathrm{Pu}$ & $0.0 \%$ & $0.0 \%$ & $0.2 \%$ & $0.3 \%$ & $1.9 \%$ & ${ }^{137} \mathrm{~m} \mathrm{Ba}$ & $0.0 \%$ & $0.0 \%$ & $0.2 \%$ & $0.3 \%$ & $1.7 \%$ \\
\hline${ }^{90} \mathrm{Y}$ & $0.0 \%$ & $0.0 \%$ & $0.2 \%$ & $0.3 \%$ & $1.7 \%$ & ${ }^{239} \mathrm{~Np}$ & $-0.3 \%$ & $-1.1 \%$ & $-1.2 \%$ & $0.0 \%$ & $0.0 \%$ \\
\hline $137 \mathrm{mBa}$ & $0.0 \%$ & $0.0 \%$ & $0.2 \%$ & $0.3 \%$ & $1.7 \%$ & ${ }^{106} \mathrm{Rh}$ & $0.0 \%$ & $-0.1 \%$ & $-0.3 \%$ & $-0.5 \%$ & $-1.2 \%$ \\
\hline${ }^{156} \mathrm{Eu}$ & $0.0 \%$ & $0.2 \%$ & $0.6 \%$ & $0.5 \%$ & $0.0 \%$ & ${ }^{144} \mathrm{Pr}$ & $0.0 \%$ & $0.1 \%$ & $0.3 \%$ & $0.6 \%$ & $1.1 \%$ \\
\hline${ }^{137} \mathrm{Cs}$ & $0.0 \%$ & $0.0 \%$ & $0.0 \%$ & $0.1 \%$ & $0.5 \%$ & ${ }^{244} \mathrm{Cm}$ & $0.0 \%$ & $0.0 \%$ & $0.1 \%$ & $0.1 \%$ & $0.7 \%$ \\
\hline${ }^{136} \mathrm{Cs}$ & $0.0 \%$ & $0.1 \%$ & $0.3 \%$ & $0.2 \%$ & $0.0 \%$ & ${ }^{239} \mathrm{U}$ & $-0.3 \%$ & $-0.5 \%$ & $0.0 \%$ & $0.0 \%$ & $0.0 \%$ \\
\hline${ }^{154} \mathrm{Eu}$ & $0.0 \%$ & $0.0 \%$ & $0.0 \%$ & $0.1 \%$ & $0.4 \%$ & ${ }^{137} \mathrm{Cs}$ & $0.0 \%$ & $0.0 \%$ & $0.0 \%$ & $0.1 \%$ & $0.5 \%$ \\
\hline${ }^{90} \mathrm{Sr}$ & $0.0 \%$ & $0.0 \%$ & $0.0 \%$ & $0.1 \%$ & $0.4 \%$ & ${ }^{90} \mathrm{Sr}$ & $0.0 \%$ & $0.0 \%$ & $0.0 \%$ & $0.1 \%$ & $0.5 \%$ \\
\hline${ }^{238} \mathrm{~Np}$ & $0.1 \%$ & $0.2 \%$ & $0.2 \%$ & $0.0 \%$ & $0.0 \%$ & ${ }^{91} \mathrm{Y}$ & $0.0 \%$ & $0.1 \%$ & $0.2 \%$ & $0.4 \%$ & $0.0 \%$ \\
\hline${ }^{239} \mathrm{~Np}$ & $-0.1 \%$ & $-0.2 \%$ & $-0.2 \%$ & $0.0 \%$ & $0.0 \%$ & ${ }^{95} \mathrm{Nb}$ & $0.0 \%$ & $0.0 \%$ & $0.2 \%$ & $0.4 \%$ & $0.0 \%$ \\
\hline${ }^{237} \mathrm{U}$ & $0.0 \%$ & $0.1 \%$ & $0.2 \%$ & $0.1 \%$ & $0.0 \%$ & ${ }^{154} \mathrm{Eu}$ & $0.0 \%$ & $0.0 \%$ & $0.0 \%$ & $0.1 \%$ & $0.4 \%$ \\
\hline Subtotal & $0.3 \%$ & $1.1 \%$ & $4.8 \%$ & $7.7 \%$ & $20.9 \%$ & Subtotal & $-0.5 \%$ & $-1.0 \%$ & $1.6 \%$ & $5.4 \%$ & $14.5 \%$ \\
\hline Total & $0.1 \%$ & $0.9 \%$ & $4.7 \%$ & $7.5 \%$ & $21.4 \%$ & Total & $1.0 \%$ & $0.8 \%$ & $3.3 \%$ & $6.7 \%$ & $15.0 \%$ \\
\hline
\end{tabular}

Increasing initial enrichment from 5 to $8 \mathrm{wt} \%$ at $60 \mathrm{GWd} / \mathrm{MTU}$ (Table 8, upper left comparison) leads to a reduction in the following isotopes: ${ }^{106} \mathrm{Rh},{ }^{134} \mathrm{Cs},{ }^{239} \mathrm{~Np},{ }^{244} \mathrm{Cm}$, and ${ }^{242} \mathrm{Cm}$. These isotopes are neutron absorption products, or they tend to result from ${ }^{239} \mathrm{Pu}$ fission, which is in turn an indirect product of neutron absorption. ${ }^{106} \mathrm{Rh}$ has a ${ }^{239} \mathrm{Pu}$ cumulative fission yield of $4.1 \mathrm{E}-2$. This is an order of magnitude larger than its ${ }^{235} \mathrm{U}$ yield of 4.1E-3, according to the Joint Evaluated Fission and Fusion File (JEFF) 3.3, as accessed through the International Atomic Energy Agency (IAEA) Live Chart of Nuclides. Note that ${ }^{134} \mathrm{Cs}$ has a small cumulative fission yield, so it tends to result from neutron activation of ${ }^{133} \mathrm{Cs}$.

${ }^{144} \mathrm{Pr}$ is generally a high-ranking decay heat contributor, behaving opposite of many of the other isotopes in the comparison charts. ${ }^{144} \mathrm{Pr}$ increases in abundance compared to the $60 \mathrm{GWd} / \mathrm{MTU} 5 \mathrm{wt} \%$ reference. It is the short-lived $\left(\mathrm{T}_{1 / 2}=17 \mathrm{~min}\right)$ progeny of ${ }^{144} \mathrm{Ce}\left(\mathrm{T}_{1 / 2}=284 \mathrm{~d}\right)$. Together, ${ }^{144} \mathrm{Ce}$ and ${ }^{144} \mathrm{Pr}$ are both progeny 
of ${ }^{144} \mathrm{La} .{ }^{144} \mathrm{La}$ and its parents in the $144 \mathrm{amu}$ beta decay series all have half-lives on the order of tens of seconds or less. ${ }^{144} \mathrm{La}$ has a ${ }^{239} \mathrm{Pu}$ cumulative fission yield of $3.59 \%$ and a ${ }^{235} \mathrm{U}$ cumulative fission yield of $5.44 \%$. ${ }^{144} \mathrm{Pr}$ cumulative fission yields are close to the ${ }^{144} \mathrm{La}$ values, with a ${ }^{239} \mathrm{Pu}$ fission yield of $3.75 \%$ and $\mathrm{a}{ }^{235} \mathrm{U}$ fission yield of $5.47 \%$. This indicates ${ }^{144} \mathrm{La}$ abundance in-core and generally reflects when the ${ }^{144} \mathrm{Pr}$ is produced. The plot of the ${ }^{144} \mathrm{La}$ abundance shown in Figure 46 reflects the observations above: ${ }^{144} \mathrm{Pr}$ tracks with its parent ${ }^{144} \mathrm{Ce}$, and ${ }^{144} \mathrm{La}$ decreases as the proportion of the power produced by ${ }^{235} \mathrm{U}$ decreases.

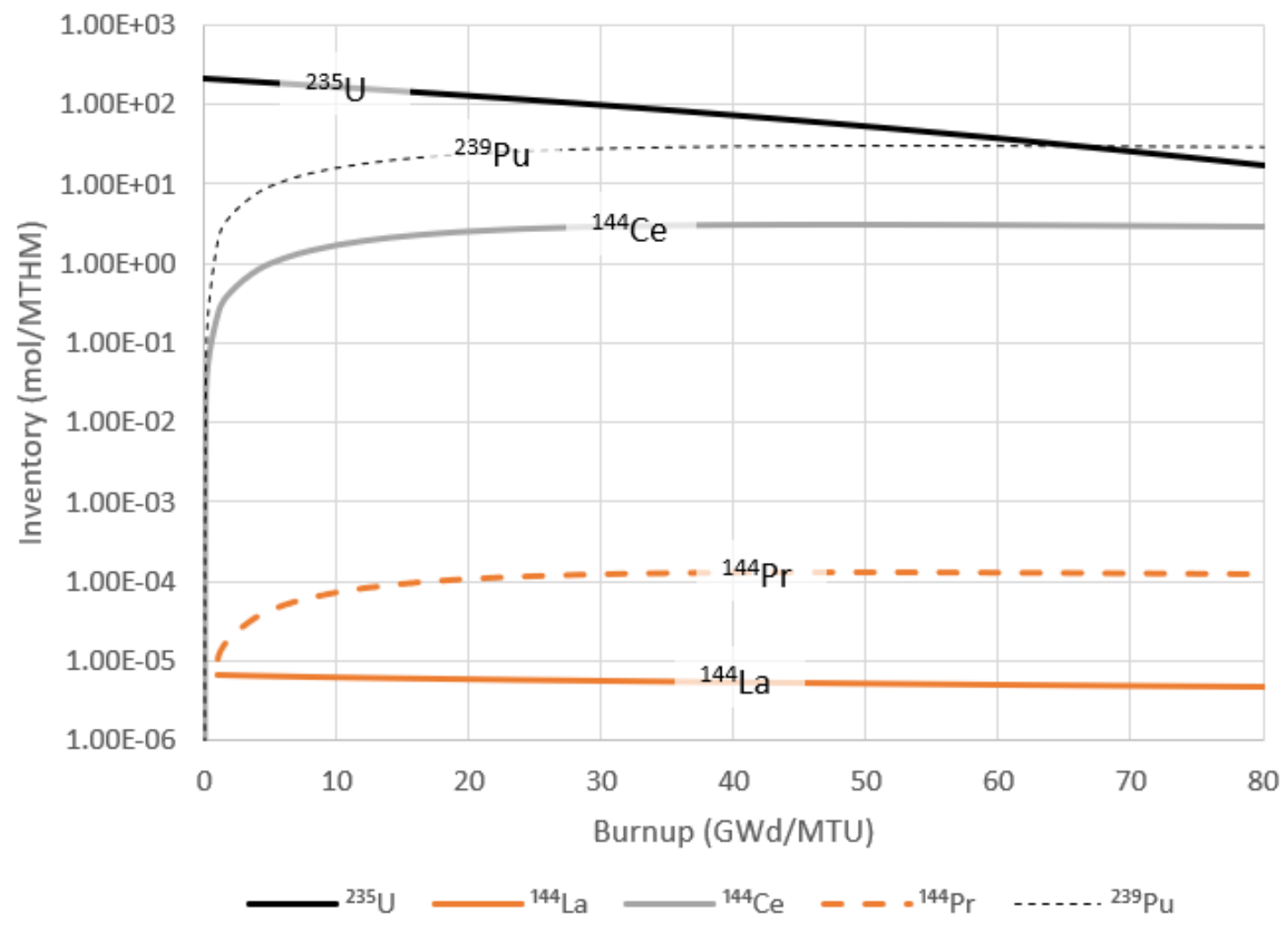

Figure 46. In-core abundances of ${ }^{144} \mathrm{Pr}$ beta chain isotopes for $5 \mathrm{wt} \%$ initial enrichment. 
Increasing burnup from the $60 \mathrm{GWd} / \mathrm{MTU} 8 \mathrm{wt} \%$ case to the $80 \mathrm{GWd} / \mathrm{MTU} 8 \mathrm{wt} \%$ case is shown in the upper right portion of the table. Here, both fission products and products of neutron absorption increase. The largest relative increases include isotopes created through neutron absorption: ${ }^{244} \mathrm{Cm}$, and ${ }^{242} \mathrm{Cm}$, or isotopes with ${ }^{239} \mathrm{Pu}$ cumulative fission yields that vastly exceed their ${ }^{235} \mathrm{U}$ yields. Notably, however, ${ }^{239} \mathrm{~Np}$ is affected less by the burnup increase than the enrichment increase discussed in the preceding paragraph. Increases in fission product decay heats are also notable with the burnup increase, specifically ${ }^{90} \mathrm{Y}$ and ${ }^{137 \mathrm{~m}} \mathrm{Ba}$. The activity of ${ }^{137 \mathrm{~m}} \mathrm{Ba}$ is typically proportional to burnup.

Increasing both enrichment and burnup from the $60 \mathrm{GWd} / \mathrm{MTU} 5 \mathrm{wt} \%$ case to the $80 \mathrm{GWd} / \mathrm{MTU} 8 \mathrm{wt} \%$ case is shown in the lower right portion of Table 8. Almost all isotopes increase in abundance when both the enrichment and burnup are increased, with the exception of ${ }^{239} \mathrm{~Np}$ and ${ }^{106} \mathrm{Rh}$. The decay heat produced by fission products ${ }^{90} \mathrm{Y}$ and ${ }^{137 \mathrm{~m}} \mathrm{Ba}$ increases .

Increasing burnup and enrichment from the $60 \mathrm{GWd} / \mathrm{MTU} 5 \mathrm{wt} \%$ case to the $80 \mathrm{GWd} / \mathrm{MTU} 6.5 \mathrm{wt} \%$ case is shown in the lower left portion of Table 8. The top 5 isotopes that contribute the most to the absolute change in decay heat are all neutron absorption products or are preferentially produced by ${ }^{239} \mathrm{Pu}$ fission.

Table 9 shows the isotopes with the largest relative changes for the same cases as Table 8. Notably, decay heats for the isotopes are much higher shortly after discharge, but shortly after discharge, each isotope contributes much less to decay heat. 
Table 9. Absolute changes in isotopic decay heat

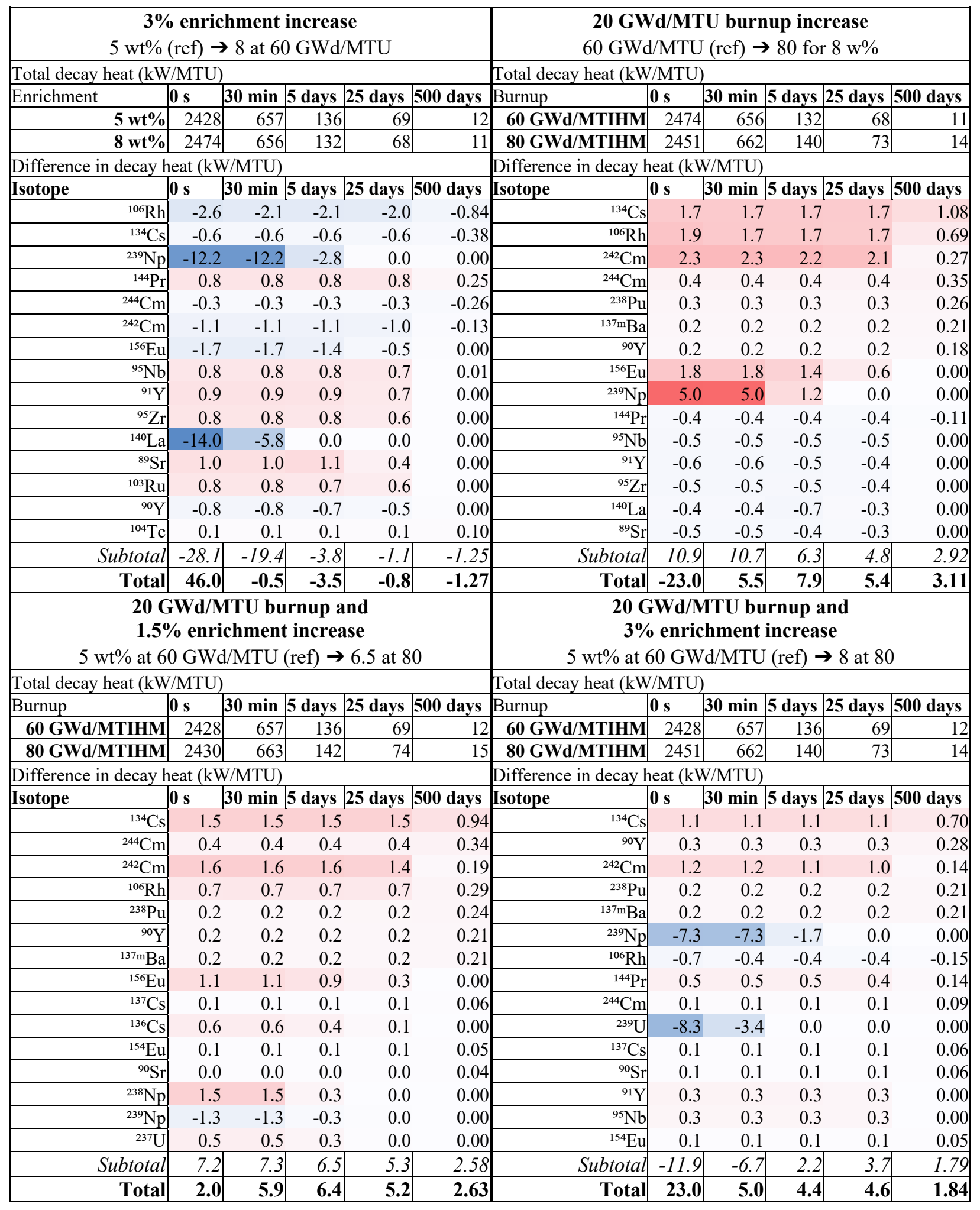




\subsection{ISOTOPES RELEVANT TO ACTIVITY}

For the four cases studied, total activity per MTU is plotted in Figure 47. Again, all four cases have similar values that begin to diverge as cooling time increases.

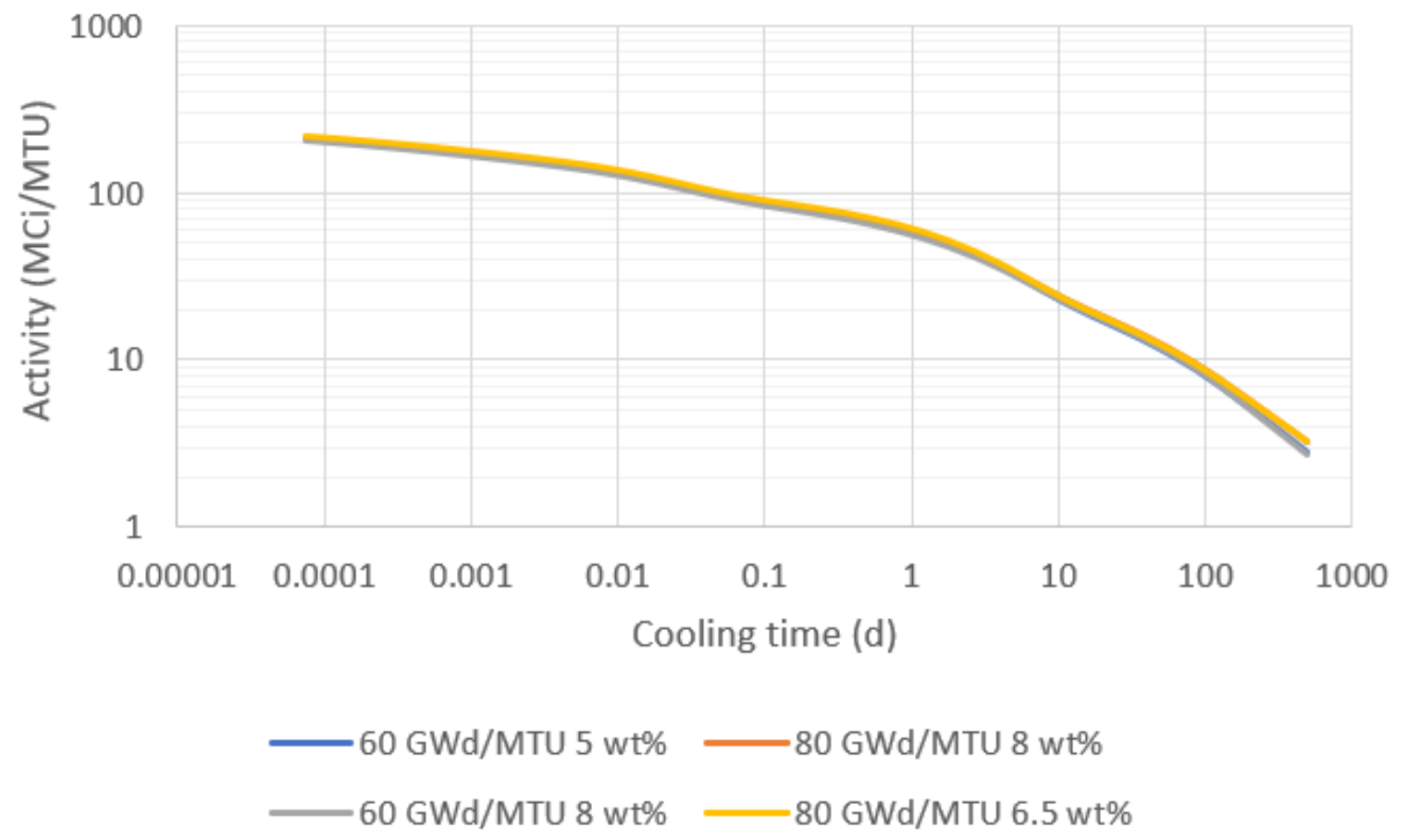

Figure 47. Activity as a function of cooling time.

Figure 48 compares the activities of three of the four cases' to that of the $60 \mathrm{GWd} / \mathrm{MTU} 5 \mathrm{wt} \%$ case as a percentage. Percent difference at each time was calculated as

$$
\frac{A}{A_{60 \text { GWd/MTU } 5 W \%}}-1 \text {, }
$$

where $A$ is total activity, and $A_{60 G W d / M T U} 5 w \%$ is the activity of the baseline case. The figure shows that total activities diverge after approximately 25 days of cooling. Again, there is an inflection point in the $8 \mathrm{wt} \%$ cases at approximately 10 days of cooling. When comparing activities in Figure 48 and decay heats in Figure 44, it is notable that changes in enrichment have a more muted effect on activity than they do on decay heat, so total activity is dominated more by burnup than decay heat. 

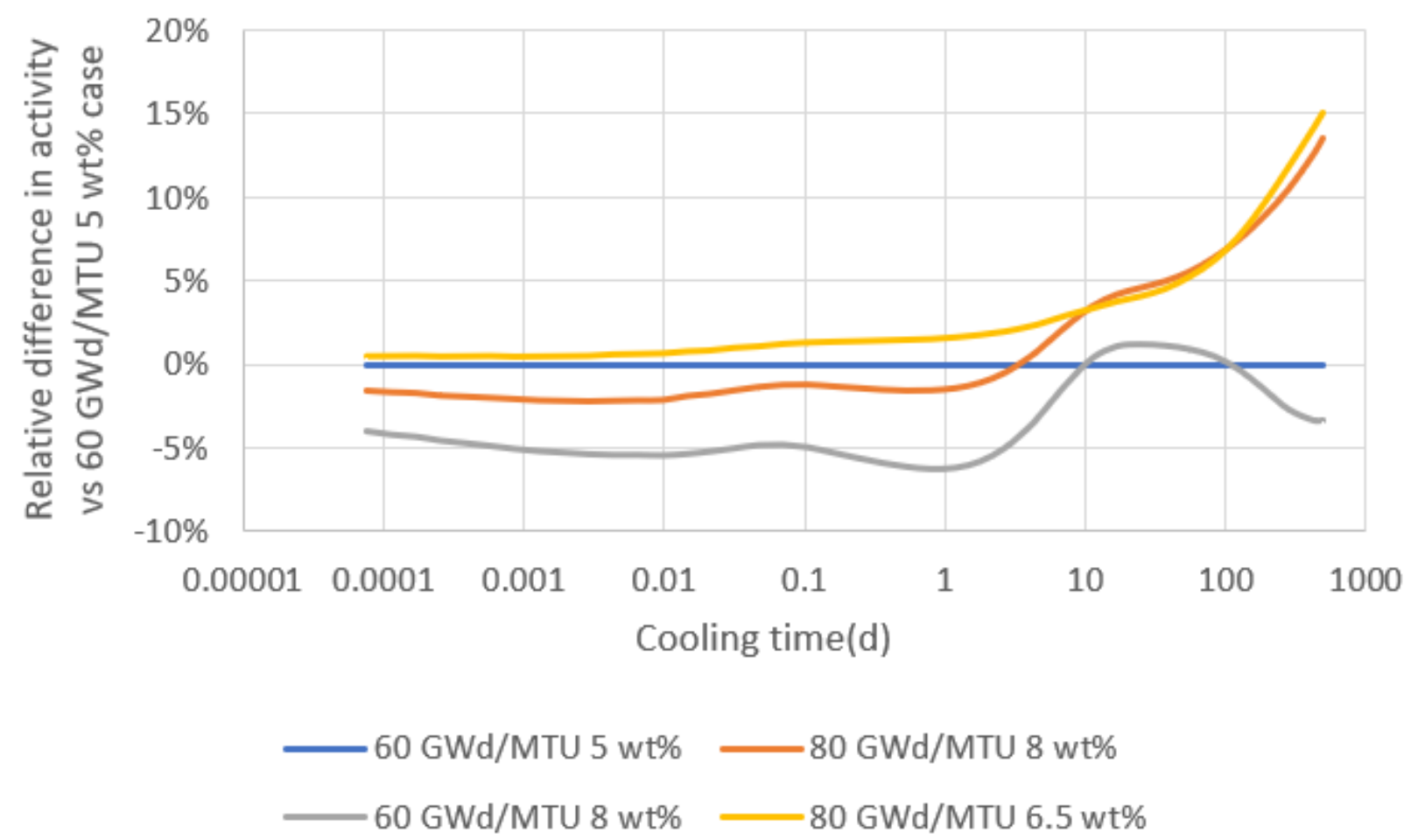

Figure 48. Activity relative to $60 \mathrm{GWd} / \mathrm{MTU} 5 \mathrm{wt} \%$ case.

A procedure similar to that used for decay heat was performed to find isotopes with large changes in activity for extended enrichment and burnup.

Table 10 shows differences in activity as a percentage of total activity. Values are differences shown as a percentage of the total activity of the second case listed in each comparison. The relative differences are computed as

$$
\frac{A_{i}-A_{i, r e f}}{A_{\text {ref }}}-1
$$

where is $A_{i}$ is activity for isotope $i$ for the first case listed in the figure heading. $A_{\text {ref }}$ is the total activity for the reference case.

Many of the same trends observed for decay heat in Table 8 and Table 9 are observed for activity in Table 10 and Table 11. Most isotopes appearing in the activity tables that were not in the decay heat tables likely result from lower energy decays, some of which are isotopes in equilibrium with others in the decay heat ranking list that produce higher energy decays. Fission products appearing in Table 10 that did not influence decay heat (see Table 8) include ${ }^{90} \mathrm{Sr},{ }^{106} \mathrm{Ru},{ }^{144} \mathrm{Ce},{ }^{103 \mathrm{~m}} \mathrm{Rh},{ }^{106} \mathrm{Ru},{ }^{137} \mathrm{Cs},{ }^{103} \mathrm{Ru}$, and ${ }^{147} \mathrm{Pm} .{ }^{241} \mathrm{Pu}$ also appears on the activity list but not the decay heat ranking. It has one of the larger changes in ranking between decay heat rankings and activity rankings. Isotopes producing more kinetic energy per decay are pushed lower in the list ranked by activity compared with the list ranked by decay heat, and they are often pushed off the list. These isotopes principally include ${ }^{242} \mathrm{Cm},{ }^{244} \mathrm{Cm}$, and ${ }^{238} \mathrm{Pu}$.

As with the decay heat, the activity is distributed across a larger number of isotopes at short cooling times and fewer isotopes at long cooling times. Like decay heat, the number of short-lived isotopes is so large 
that it exceeds the length of the list, but all the isotopes at short cooling times make a small contribution to change in total activity. Longer activity lists are presented in the appendix, and they explicitly show activities for isotopes contributing more than $0.1 \%$ of the total calculated activity. At longer cooling times, fewer isotopes are decaying, so the total change in activity from the isotopes that are shown more closely matches the total calculated change in activity. No single isotope changes total activity by more than $5 \%$ in any of the comparisons.

Table 10. Differences in isotopic activity differences shown as a percentage of the total activity

\begin{tabular}{|c|c|c|c|c|c|c|c|c|c|c|c|}
\hline \multicolumn{6}{|c|}{$\begin{array}{c}\text { 3\% enrichment increase } \\
5 \mathrm{wt} \% \text { (ref) } \rightarrow 8 \text { at } 60 \mathrm{GWd} / \mathrm{MTU}\end{array}$} & \multicolumn{6}{|c|}{$\begin{array}{c}20 \mathrm{GWd} / \mathrm{MTU} \text { burnup increase } \\
60 \mathrm{GWd} / \mathrm{MTU} \text { (ref) } \rightarrow 80 \text { for } 8 \mathrm{w} \%\end{array}$} \\
\hline Isotope & $0 \mathrm{~s}$ & $30 \mathrm{~min}$ & 5 days & 25 days & 500 days & Isotope & $0 \mathrm{~s}$ & $30 \mathrm{~min}$ & 5 days & 25 days & 500 days \\
\hline${ }^{239} \mathrm{~Np}$ & $-2.1 \%$ & $-4.3 \%$ & $-3.6 \%$ & $0.0 \%$ & $0.0 \%$ & ${ }^{134} \mathrm{Cs}$ & $0.1 \%$ & $0.2 \%$ & $0.5 \%$ & $1.0 \%$ & $3.9 \%$ \\
\hline${ }^{106} \mathrm{Rh}$ & $-0.1 \%$ & $-0.2 \%$ & $-0.7 \%$ & $-1.3 \%$ & $-3.1 \%$ & ${ }^{106} \mathrm{Rh}$ & $0.1 \%$ & $0.2 \%$ & $0.6 \%$ & $1.1 \%$ & $2.6 \%$ \\
\hline${ }^{106} \mathrm{Ru}$ & $-0.1 \%$ & $-0.2 \%$ & $-0.7 \%$ & $-1.3 \%$ & $-3.1 \%$ & ${ }^{106} \mathrm{Ru}$ & $0.1 \%$ & $0.2 \%$ & $0.6 \%$ & $1.1 \%$ & $2.6 \%$ \\
\hline${ }^{239} \mathrm{U}$ & $-2.1 \%$ & $-1.8 \%$ & $0.0 \%$ & $0.0 \%$ & $0.0 \%$ & ${ }^{239} \mathrm{~Np}$ & $0.9 \%$ & $1.8 \%$ & $1.5 \%$ & $0.0 \%$ & $0.0 \%$ \\
\hline${ }^{144} \mathrm{Ce}$ & $0.0 \%$ & $0.1 \%$ & $0.3 \%$ & $0.7 \%$ & $1.2 \%$ & ${ }^{137} \mathrm{Cs}$ & $0.0 \%$ & $0.1 \%$ & $0.2 \%$ & $0.4 \%$ & $2.1 \%$ \\
\hline${ }^{144} \mathrm{Pr}$ & $0.0 \%$ & $0.1 \%$ & $0.3 \%$ & $0.7 \%$ & $1.2 \%$ & ${ }^{137} \mathrm{~m} \mathrm{Ba}$ & $0.0 \%$ & $0.0 \%$ & $0.2 \%$ & $0.3 \%$ & $2.0 \%$ \\
\hline${ }^{91} \mathrm{Y}$ & $0.1 \%$ & $0.2 \%$ & $0.7 \%$ & $1.2 \%$ & $0.0 \%$ & ${ }^{241} \mathrm{Pu}$ & $0.0 \%$ & $0.0 \%$ & $0.2 \%$ & $0.3 \%$ & $1.8 \%$ \\
\hline${ }^{134} \mathrm{Cs}$ & $0.0 \%$ & $-0.1 \%$ & $-0.2 \%$ & $-0.4 \%$ & $-1.3 \%$ & ${ }^{90} \mathrm{Y}$ & $0.0 \%$ & $0.0 \%$ & $0.1 \%$ & $0.2 \%$ & $1.2 \%$ \\
\hline${ }^{89} \mathrm{Sr}$ & $0.1 \%$ & $0.2 \%$ & $0.6 \%$ & $1.0 \%$ & $0.0 \%$ & 90 $\mathrm{Sr}$ & $0.0 \%$ & $0.0 \%$ & 0. & $0.2 \%$ & $1.2 \%$ \\
\hline${ }^{103} \mathrm{Ru}$ & $-0.1 \%$ & $-0.2 \%$ & $-0.6 \%$ & $-0.9 \%$ & $0.0 \%$ & ${ }^{239} \mathrm{U}$ & $0.9 \%$ & $0.8 \%$ & $0.0 \%$ & $0.0 \%$ & $0.0 \%$ \\
\hline${ }^{147} \mathrm{Pm}$ & $0.0 \%$ & $0.0 \%$ & $0.1 \%$ & $0.3 \%$ & $1.1 \%$ & ${ }^{91} \mathrm{Y}$ & $-0.1 \%$ & $-0.1 \%$ & $-0.5 \%$ & $-0.7 \%$ & $0.0 \%$ \\
\hline $103 \mathrm{~m} R \mathrm{R}$ & $-0.1 \%$ & $-0.2 \%$ & $-0.6 \%$ & $-0.9 \%$ & $0.0 \%$ & ${ }^{89} \mathrm{Sr}$ & $-0.1 \%$ & $-0.1 \%$ & $-0.4 \%$ & $-0.6 \%$ & $0.0 \%$ \\
\hline${ }^{95} \mathrm{Nb}$ & $0.1 \%$ & $0.1 \%$ & $0.5 \%$ & $1.0 \%$ & $0.1 \%$ & ${ }^{95} \mathrm{Nb}$ & $0.0 \%$ & $-0.1 \%$ & $-0.3 \%$ & $-0.6 \%$ & $0.0 \%$ \\
\hline${ }^{95} \mathrm{Zr}$ & $0.1 \%$ & $0.1 \%$ & $0.5 \%$ & $0.8 \%$ & $0.0 \%$ & ${ }^{103} \mathrm{Ru}$ & $0.1 \%$ & $0.1 \%$ & $0.4 \%$ & $0.6 \%$ & $0.0 \%$ \\
\hline${ }^{90} \mathrm{Sr}$ & $0.0 \%$ & $0.0 \%$ & $0.1 \%$ & $0.1 \%$ & $0.6 \%$ & 103m Rh & $0.1 \%$ & $0.1 \%$ & $0.4 \%$ & $0.6 \%$ & $0.0 \%$ \\
\hline Subtotal & $-4.2 \%$ & $-6.0 \%$ & $-3.1 \%$ & $0.8 \%$ & $-3.2 \%$ & Subtotal & $2.1 \%$ & $3.2 \%$ & $3.5 \%$ & $3.8 \%$ & $17.3 \%$ \\
\hline Total & $-3.3 \%$ & $-5.2 \%$ & $-2.8 \%$ & $1.2 \%$ & $3 \%$ & & $2.0 \%$ & $3.5 \%$ & $4.0 \%$ & $3.3 \%$ & $.5 \%$ \\
\hline \multicolumn{6}{|c|}{$\begin{array}{l}20 \mathrm{GWd} / \mathrm{MTU} \text { burnup and } \\
1.5 \% \text { enrichment increase }\end{array}$} & \multicolumn{6}{|c|}{$\begin{array}{c}20 \text { GWd/MTU burnup and } \\
3 \% \text { enrichment increase }\end{array}$} \\
\hline \multicolumn{6}{|c|}{$5 \mathrm{wt} \%$ at $60 \mathrm{GWd} / \mathrm{MTU}(\mathrm{ref}) \rightarrow 6.5$ at 80} & \multicolumn{6}{|c|}{$5 \mathrm{wt} \%$ at $60 \mathrm{GWd} / \mathrm{MTU}(\mathrm{ref}) \rightarrow 8$ at 80} \\
\hline socope & $\mathbf{0 s}$ & $30 \mathrm{~min}$ & 5 days & 25 days & 500 days & Isotope & $\mathbf{0 s}$ & 30 min & 5 days & 25 days & 500 \\
\hline${ }^{134} \mathrm{Cs}$ & $0.1 \%$ & $0.1 \%$ & $0.4 \%$ & $0.9 \%$ & $3.3 \%$ & ${ }^{239} \mathrm{~Np}$ & $-1.3 \%$ & $-2.6 \%$ & $-2.1 \%$ & $0.0 \%$ & $0.0 \%$ \\
\hline${ }^{137} \mathrm{Cs}$ & $0.0 \%$ & $0.0 \%$ & $0.2 \%$ & $4 \%$ & $2.0 \%$ & ${ }^{134} \mathrm{Cs}$ & $0.0 \%$ & $0.1 \%$ & $0.3 \%$ & $0.7 \%$ & $2.4 \%$ \\
\hline $137 \mathrm{~m} \mathrm{Ba}$ & $0.0 \%$ & $0.0 \%$ & $0.2 \%$ & $3 \%$ & $1.9 \%$ & ${ }^{137} \mathrm{Cs}$ & $0.0 \%$ & $0.1 \%$ & $0.2 \%$ & $0.4 \%$ & $2.0 \%$ \\
\hline${ }^{90} \mathrm{Sr}$ & $0.0 \%$ & $0.0 \%$ & $0.1 \%$ & $3 \%$ & $1.4 \%$ & $137 \mathrm{~m} \mathrm{Ba}$ & $0.0 \%$ & $0.0 \%$ & $\%$ & $0.4 \%$ & $1.9 \%$ \\
\hline${ }^{90} \mathrm{Y}$ & $0.0 \%$ & $0.0 \%$ & $0.1 \%$ & & $1.4 \%$ & ${ }^{90} \mathrm{Sr}$ & $0.0 \%$ & $0.0 \%$ & $0.2 \%$ & $0.3 \%$ & $1.8 \%$ \\
\hline${ }^{241} \mathrm{Pu}$ & $0.0 \%$ & $0.0 \%$ & $0.1 \%$ & $2 \%$ & $1.3 \%$ & ${ }^{90} \mathrm{Y}$ & $0.0 \%$ & $0.0 \%$ & $0.2 \%$ & $0.3 \%$ & $1.8 \%$ \\
\hline${ }^{106} \mathrm{Ru}$ & $0.0 \%$ & $0.1 \%$ & $0.2 \%$ & & & ${ }^{239} \mathrm{U}$ & $-1.3 \%$ & $-1.1 \%$ & $0.0 \%$ & $0.0 \%$ & $0.0 \%$ \\
\hline${ }^{106} \mathrm{Rh}$ & $0.0 \%$ & $0.1 \%$ & $0.2 \%$ & $5 \%$ & $1.1 \%$ & ${ }^{241} \mathrm{Pu}$ & $0.0 \%$ & $0.0 \%$ & $\%$ & $0.3 \%$ & $1.5 \%$ \\
\hline${ }^{239} \mathrm{~Np}$ & $-0.2 \%$ & $-0.5 \%$ & $-0.4 \%$ & $0 \%$ & $0.0 \%$ & ${ }^{147} \mathrm{Pm}$ & $0.0 \%$ & $0.0 \%$ & $0.1 \%$ & $0.2 \%$ & $0.9 \%$ \\
\hline${ }^{237} \mathrm{U}$ & $0.1 \%$ & $0.2 \%$ & $0.5 \%$ & $\%$ & $.0 \%$ & ${ }^{144} \mathrm{Ce}$ & $0.0 \%$ & $0.1 \%$ & $0.2 \%$ & $.4 \%$ & $0.7 \%$ \\
\hline${ }^{244} \mathrm{Cm}$ & $0.0 \%$ & $0.0 \%$ & $0 \%$ & $1 \%$ & $0.3 \%$ & ${ }^{144} \mathrm{Pr}$ & $0.0 \%$ & $0.1 \%$ & $0.2 \%$ & $0.4 \%$ & $0.7 \%$ \\
\hline${ }^{156} \mathrm{Eu}$ & $0.0 \%$ & $0.1 \%$ & $0.3 \%$ & $0.2 \%$ & $0.0 \%$ & ${ }^{237} \mathrm{U}$ & $0.1 \%$ & $0.3 \%$ & $0.6 \%$ & $0.2 \%$ & $0.0 \%$ \\
\hline${ }^{147} \mathrm{Pm}$ & $0.0 \%$ & $0.0 \%$ & $0.0 \%$ & $0.1 \%$ & $0.3 \%$ & ${ }^{106} \mathrm{Rh}$ & $0.0 \%$ & $0.0 \%$ & $-0.1 \%$ & $-0.2 \%$ & $-0.6 \%$ \\
\hline${ }^{238} \mathrm{~Np}$ & $0.1 \%$ & $0.3 \%$ & $.2 \%$ & $\%$ & $0.0 \%$ & ${ }^{106} \mathrm{Ru}$ & $0.0 \%$ & $0.0 \%$ & $-0.1 \%$ & $-0.2 \%$ & $-0.6 \%$ \\
\hline${ }^{242} \mathrm{Cm}$ & $0.0 \%$ & $0.0 \%$ & $0.1 \%$ & $0.2 \%$ & $0.2 \%$ & ${ }^{91} \mathrm{Y}$ & $0.0 \%$ & $0.1 \%$ & $0.3 \%$ & $0.4 \%$ & $0.0 \%$ \\
\hline Subtotal & $0.3 \%$ & $0.6 \%$ & $2.3 \%$ & $4.0 \%$ & $14.2 \%$ & Subtotal & $-2.2 \%$ & $-2.9 \%$ & $0.1 \%$ & $3.4 \%$ & $12.6 \%$ \\
\hline Total & $0.4 \%$ & $0.8 \%$ & $2.4 \%$ & $4.0 \%$ & $15.1 \%$ & Total & $-1.3 \%$ & $-1.8 \%$ & $1.0 \%$ & $4.6 \%$ & $13.6 \%$ \\
\hline
\end{tabular}


Table 11. Absolute changes in isotopic activity

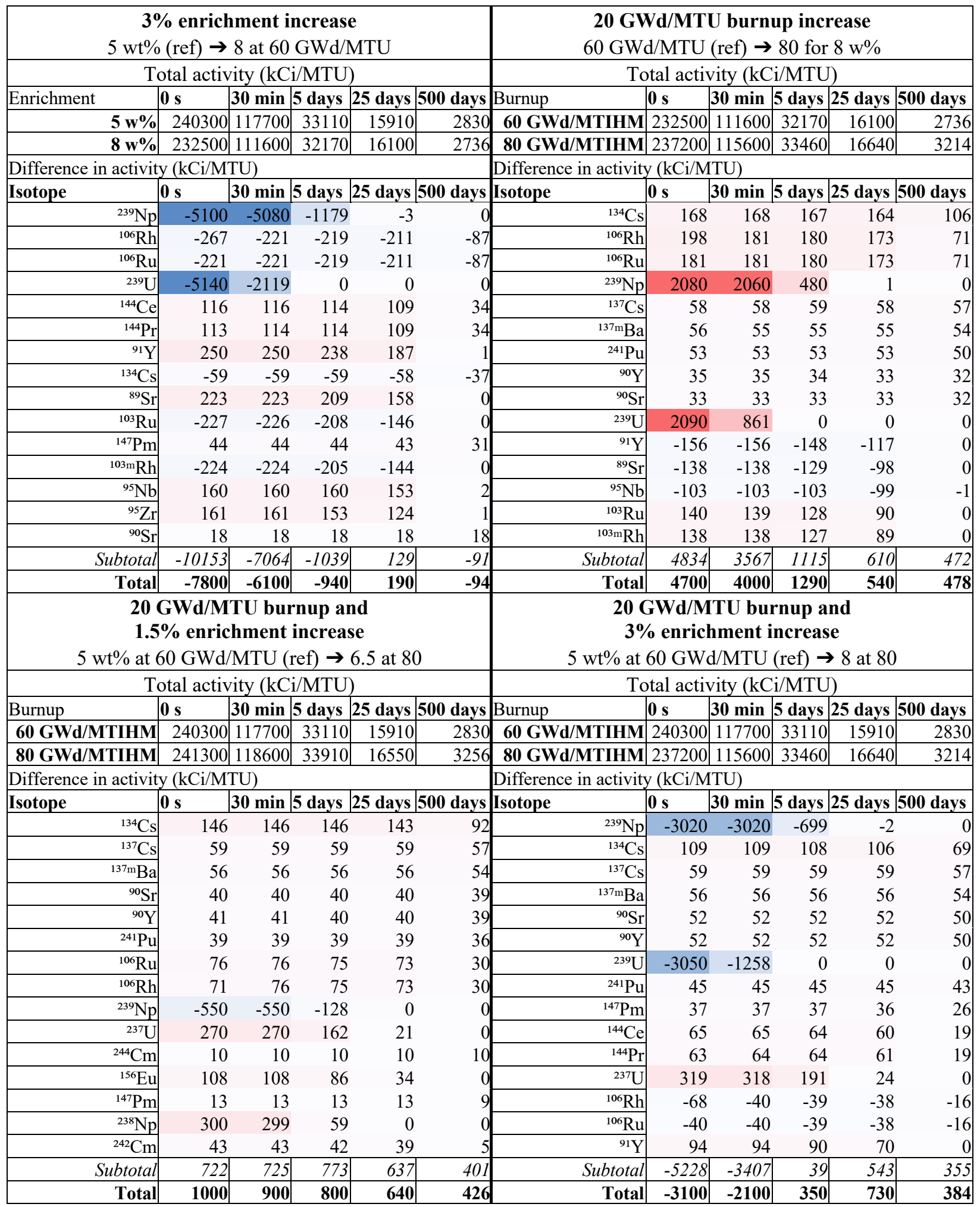


Table 11 shows absolute differences in activity for isotopes ranking highest in change vs total activity. Once again, ${ }^{239} \mathrm{~Np}$ dominates, and changes are larger at shorter cooling times than at longer cooling times. However, as seen in the case of decay heat, changes at shorter cooling times are proportionally smaller. Changes at shorter cooling times also depend more on specific power than burnup or initial enrichment, except for ${ }^{239} \mathrm{~Np}$.

\subsection{ISOTOPES RELEVANT TO ACCIDENT RELEASE SOURCE TERM}

In addition to isotopes that contribute to large changes in activity, some may also be important to the release source term. To screen for these, the list of elements in Regulatory Guide 1.183, Alternative Radiological Source Terms for Evaluating Design Basis Accidents at Nuclear Power Reactors, lists these elements that must be considered when considering the alternative release source terms provided in Table 5 of that document [7]:

- Noble gases: $\mathrm{Xe}, \mathrm{Kr}$

- Halogens: I, Br

- Alkali metals: Cs, $\mathrm{Rb}$

- Tellurium group: Te, $\mathrm{Sb}, \mathrm{Se}, \mathrm{Ba}, \mathrm{Sr}$

- Noble metals: Ru, Rh, Pd, Mo, Tc, Co

- Lanthanides: La, Zr, Nd, Eu, Nb, Pm, Pr, Sm, Y, Cm, Am

- Cerium: $\mathrm{Ce}, \mathrm{Pu}, \mathrm{Np}$

Most of these isotopes' relative contributions to activity are listed in the appendix to this document. Every isotope of these elements included in SCALE was modeled, but only those creating more than a $0.1 \%$ of total activity at any evaluated timepoint are listed. Comparisons showing the effects of increases in burnup and enrichment for a selection of isotopes are shown in Table 12. Percent changes are shown compared to the isotope activity, $A_{i, 2}$, in the reference case for each comparison in the table heading.

$$
\frac{A_{i, 1}}{A_{i, 2}}-1 \text {. }
$$


Table 12. Change in activity of selected "accident release" isotopes

\begin{tabular}{|c|c|c|c|c|c|c|c|c|c|c|c|}
\hline \multicolumn{6}{|c|}{$\begin{array}{c}\text { 3\% enrichment increase } \\
5 \mathrm{wt} \% \text { (ref) } \rightarrow 8 \text { at } 60 \mathrm{GWd} / \mathrm{MTU}\end{array}$} & \multicolumn{6}{|c|}{$\begin{array}{c}20 \mathrm{GWd} / \mathrm{MTU} \text { burnup increase } \\
60 \mathrm{GWd} / \mathrm{MTU} \text { (ref) } \rightarrow 80 \text { for } 8 \mathrm{w} \%\end{array}$} \\
\hline Isotope & $\mathbf{0 s}$ & 30 min & 5 days & 25 days & 500 days & Isotope & $0 \mathrm{~s}$ & 30 min & 5 days & 25 days & 500 days \\
\hline${ }^{137} \mathrm{Cs}$ & $0.37 \%$ & $0.37 \%$ & $0.37 \%$ & $0.37 \%$ & $0.38 \%$ & ${ }^{137} \mathrm{Cs}$ & $31.02 \%$ & $31.02 \%$ & $31.03 \%$ & $97 \%$ & $.96 \%$ \\
\hline${ }^{131} \mathbf{I}$ & $-2.24 \%$ & $.24 \%$ & $-2.47 \%$ & $-2.54 \%$ & $-2.53 \%$ & ${ }^{131} I$ & $1.05 \%$ & $1.04 \%$ & $7 \%$ & $1.16 \%$ & $.20 \%$ \\
\hline${ }^{133} \mathbf{I}$ & $1.40 \%$ & & $1.46 \%$ & $1.46 \%$ & 1 & ${ }^{133} \mathrm{I}$ & $-1.08 \%$ & & & & \\
\hline${ }^{135} \mathbf{I}$ & $0.61 \%$ & & 8 & & & ${ }^{135} I$ & & & & & \\
\hline${ }^{85} \mathbf{K r}$ & $12.52 \%$ & $12.52 \%$ & $12.50 \%$ & $12.52 \%$ & $53 \%$ & ${ }^{85} \mathrm{Kr}$ & $20.54 \%$ & $20.54 \%$ & $20.56 \%$ & $4 \%$ & $.54 \%$ \\
\hline${ }^{90} \mathrm{Sr}$ & $14.35 \%$ & $14.35 \%$ & $14.28 \%$ & $14.32 \%$ & $6 \%$ & ${ }^{90} \mathrm{Sr}$ & $23.03 \%$ & $23.03 \%$ & $23.05 \%$ & $23.07 \%$ & $23.01 \%$ \\
\hline \multicolumn{6}{|c|}{$\begin{array}{l}20 \mathrm{GWd} / \mathrm{MTU} \text { burnup and } \\
1.5 \% \text { enrichment increase }\end{array}$} & \multicolumn{6}{|c|}{$\begin{array}{l}20 \mathrm{GWd} / \mathrm{MTU} \text { burnup and } \\
3 \% \text { enrichment increase }\end{array}$} \\
\hline sotope & $0 \mathrm{~s}$ & 30 min & 5 days & 25 days & 500 days & pe & $0 \mathrm{~s}$ & 30 & $5 d$ & 25 days & 500 days \\
\hline${ }^{137} \mathrm{Cs}$ & $31.22 \%$ & $31.22 \%$ & $24 \%$ & $31.22 \%$ & $31.22 \%$ & ${ }^{137} \mathrm{Cs}$ & $31.50 \%$ & $31.50 \%$ & $52 \%$ & $31.45 \%$ & $31.46 \%$ \\
\hline${ }^{131} \mathbf{I}$ & $-0.23 \%$ & $-0.23 \%$ & $23 \%$ & $-0.28 \%$ & $-0.25 \%$ & ${ }^{131} \mathrm{I}$ & $-1.21 \%$ & $-1.22 \%$ & $-1.33 \%$ & $-1.41 \%$ & $-1.36 \%$ \\
\hline${ }^{133} \mathbf{I}$ & $-0.36 \%$ & $-0.42 \%$ & $9 \%$ & $-0.39 \%$ & 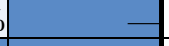 & ${ }^{133} \mathrm{I}$ & $0.31 \%$ & $0.31 \%$ & $0.36 \%$ & $0.34 \%$ & \\
\hline${ }^{135} \mathbf{I}$ & $-0.29 \%$ & $-0.27 \%$ & $-0.27 \%$ & & 二 & ${ }^{135} \mathrm{I}$ & $0.03 \%$ & $0.05 \%$ & $0.05 \%$ & & \\
\hline${ }^{85} \mathrm{Kr}$ & $27.80 \%$ & $27.80 \%$ & $27.80 \%$ & $27.80 \%$ & $27.79 \%$ & ${ }^{85} \mathrm{Kr}$ & $35.63 \%$ & $35.63 \%$ & $35.63 \%$ & $35.64 \%$ & $35.64 \%$ \\
\hline${ }^{90} \mathrm{Sr}$ & $31.54 \%$ & $31.54 \%$ & $31.58 \%$ & $31.54 \%$ & $31.56 \%$ & ${ }^{90} \mathrm{Sr}$ & $40.68 \%$ & $40.68 \%$ & $40.62 \%$ & $40.69 \%$ & $40.67 \%$ \\
\hline
\end{tabular}

\subsection{ISOTOPES RELEVANT TO RADIATION SHIELDING SOURCE TERM}

Changes in the isotopes important to cask shielding in NUREG 6700 [8] are evaluated in this section, with the notable exception of ${ }^{60} \mathrm{Co}$, which is an assembly hardware activation product. Activation products are dependent on the assembly hardware metal and its impurities, which can vary from batch to batch of metal depending on the source ore body. Assembly hardware is typically more proprietary than lattice designs, and it is not examined in this report. This list of isotopes is developed for longer time frames, such as 5 years. Given that relative contributions of short-lived isotopes are mostly dependent on operating power, this should be reasonable. Note that these are simply common isotopes for cask shielding, and other isotopes may be dominant depending on the application. Table 13 presents the percent each isotope increases or decreases in activity on an isotope basis. The relative difference for each isotope's activity is computed as

$$
\frac{A_{i, 1}}{A_{i, 2}}-1 \text {. }
$$

The largest relative changes are for actinides and isotopes such as ${ }^{106} \mathrm{Rh}$. Aside from the $\mathrm{Cm}$ isotopes (addressed in the next section), given that there are no changes exceeding $100 \%$, the existing methods for shielding should remain suitable. 
The $\mathrm{Cm}$ isotopes in Table 13 have large changes when burnup or enrichment change. This is largely due to the isotopes requiring numerous neutrons to be produced, and the fact that ${ }^{245} \mathrm{Cm}$ is fissile, resulting in few higher actinides being produced. If probability for each neutron absorption were equal and parent nuclides did not saturate, then ${ }^{246} \mathrm{Cm}$ abundance would scale with burnup to the eighth power because it requires 8 neutrons to produce. Several isotopes on the activation chain leading to ${ }^{244} \mathrm{Cm}$ and ${ }^{246} \mathrm{Cm}$ are shown in Figure 49, along with ${ }^{235} \mathrm{U}$. It is clearly observable that as the mass number increases, the upward slope on the semi-log plot increases, with ${ }^{246} \mathrm{Cm}$ being the most sensitive to burnup and enrichment. Thus, it is unsurprising that such large changes are observed in the $\mathrm{Cm}$ isotopes. Also note that the net change from a combined $602 \%$ increase and a $81 \%$ decrease is indeed a net $32 \%$ increase, so the results for ${ }^{246} \mathrm{Cm}$ in the upper half of the table combine to give the result in the lower righthand quadrant. This is consistent with the generally observed behavior of burnup and enrichment effects canceling each other.

Table 13. Change in activity of shielding isotopes

\begin{tabular}{|c|c|c|c|c|c|c|c|c|c|c|c|}
\hline \multicolumn{6}{|c|}{$\begin{array}{c}\text { 3\% enrichment increase } \\
5 \mathrm{wt} \%(\mathrm{ref}) \rightarrow 8 \text { at } 60 \mathrm{GWd} / \mathrm{MTU}\end{array}$} & \multicolumn{6}{|c|}{$\begin{array}{c}20 \mathrm{GWd} / \text { MTU burnup increase } \\
60 \mathrm{GWd} / \mathrm{MTU}(\text { ref }) \rightarrow 80 \text { for } 8 \mathrm{w} \%\end{array}$} \\
\hline Isotope & $0 \mathrm{~s}$ & 30 min & 5 days & 25 days & 500 days & Isotope & $\mathbf{0 ~ s}$ & $30 \mathrm{~min}$ & 5 days & 25 days & 500 days \\
\hline${ }^{241} \mathrm{Am}$ & $15.5 \%$ & $15.5 \%$ & $15.1 \%$ & $13.8 \%$ & $3.1 \%$ & ${ }^{241} \mathrm{Am}$ & $34.8 \%$ & $34.8 \%$ & $34.6 \%$ & $34.0 \%$ & $8.1 \%$ \\
\hline${ }^{137 \mathrm{~m}} \mathrm{Ba}$ & $0.3 \%$ & $.4 \%$ & $0.4 \%$ & $0.4 \%$ & $0.3 \%$ & ${ }^{137 \mathrm{~m}} \mathrm{Ba}$ & $31.0 \%$ & $31.0 \%$ & $31.0 \%$ & $31.0 \%$ & $1.0 \%$ \\
\hline${ }^{244} \mathrm{Cm}$ & $-63.2 \%$ & $-63.2 \%$ & $-63.2 \%$ & $-63.2 \%$ & $-63.2 \%$ & ${ }^{244} \mathrm{Cm}$ & $230.4 \%$ & $230.4 \%$ & $230.6 \%$ & $0.6 \%$ & $0.5 \%$ \\
\hline${ }^{246} \mathrm{Cm}$ & $-81.2 \%$ & $-81.2 \%$ & $-81.2 \%$ & $-81.2 \%$ & $-81.2 \%$ & ${ }^{246} \mathrm{Cm}$ & $602.6 \%$ & $602.6 \%$ & $602.6 \%$ & $602.6 \%$ & $2.6 \%$ \\
\hline${ }^{134} \mathrm{Cs}$ & $-16.4 \%$ & $-16.4 \%$ & $-16.4 \%$ & $-16.4 \%$ & $-16.4 \%$ & ${ }^{134} \mathrm{Cs}$ & $55.7 \%$ & $55.7 \%$ & & $55.6 \%$ & $.7 \%$ \\
\hline${ }^{154} \mathrm{Eu}$ & $-1.8 \%$ & $-1.8 \%$ & $1.8 \%$ & $-1.8 \%$ & $-1.8 \%$ & ${ }^{154} \mathrm{Eu}$ & $43.5 \%$ & $43.5 \%$ & $43.5 \%$ & $43.5 \%$ & $.5 \%$ \\
\hline${ }^{144} \operatorname{Pr}$ & $7.9 \%$ & $8.0 \%$ & $8.1 \%$ & $8.1 \%$ & $8.1 \%$ & ${ }^{144} \mathrm{Pr}$ & $-3.2 \%$ & $-3.2 \%$ & & $3 \%$ & $3 \%$ \\
\hline${ }^{238} \mathrm{Pu}$ & $-13.7 \%$ & $-13.7 \%$ & $-13.7 \%$ & $-13.8 \%$ & $14.4 \%$ & ${ }^{238} \mathrm{Pu}$ & 94 & $0 \%$ & $3 \%$ & $6 \%$ & $.8 \%$ \\
\hline${ }^{239} \mathrm{Pu}$ & $21.6 \%$ & $21.6 \%$ & $21.2 \%$ & $21.0 \%$ & $21.0 \%$ & ${ }^{239} \mathrm{Pu}$ & $-0.9 \%$ & $-0.9 \%$ & $-0.8 \%$ & $0.8 \%$ & $0.8 \%$ \\
\hline${ }^{240} \mathrm{Pu}$ & $-13.5 \%$ & $.5 \%$ & & $5 \%$ & $.6 \%$ & ${ }^{240} \mathrm{Pu}$ & & & & & $1 \%$ \\
\hline${ }^{242} \mathrm{Pu}$ & $-43.8 \%$ & $-43.8 \%$ & $-43.8 \%$ & $-43.8 \%$ & $-43.8 \%$ & ${ }^{242} \mathrm{Pu}$ & $87.8 \%$ & $87.8 \%$ & $\%$ & $3 \%$ & $.8 \%$ \\
\hline${ }^{106} \mathrm{Rh}$ & $-28.5 \%$ & $-26.3 \%$ & $-26.3 \%$ & $-26.3 \%$ & $-26.3 \%$ & ${ }^{106} \mathrm{Rh}$ & $29.7 \%$ & $29.2 \%$ & & & $2 \%$ \\
\hline${ }^{90} \mathrm{Y}$ & $12.7 \%$ & $12.7 \%$ & $13.8 \%$ & $14.3 \%$ & & ${ }^{0} \mathrm{Y}$ & $23.8 \%$ & $23.8 \%$ & & $1 \%$ & $1 \%$ \\
\hline \multicolumn{6}{|c|}{$\begin{array}{l}20 \mathrm{GWd} / \mathrm{MTU} \text { burnup and } \\
\mathbf{1 . 5 \%} \text { enrichment increase }\end{array}$} & \multicolumn{6}{|c|}{$\begin{array}{l}20 \mathrm{GWd} / \mathrm{MTU} \text { burnup and } \\
3 \% \text { enrichment increase }\end{array}$} \\
\hline otope & $0 \mathrm{~s}$ & $30 \mathrm{~min}$ & 5 days & 25 days & 500 & otope & $0 \mathrm{~s}$ & 30 min & 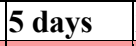 & 5 days & 500 \\
\hline${ }^{241} \mathrm{Am}$ & $35.5 \%$ & $35.5 \%$ & $35.2 \%$ & $33.8 \%$ & $3.2 \%$ & ${ }^{241} \mathrm{Am}$ & $55.6 \%$ & $55.6 \%$ & $\%$ & $4 \%$ & $1 \%$ \\
\hline${ }^{137 m} \mathrm{Ba}$ & $31.1 \%$ & $.2 \%$ & $3 \%$ & $31.2 \%$ & $31.2 \%$ & ${ }^{137 \mathrm{~m}} \mathrm{Ba}$ & $31.4 \%$ & $31.5 \%$ & $5 \%$ & $5 \%$ & $.5 \%$ \\
\hline${ }^{244} \mathrm{Cm}$ & $82.7 \%$ & $82.7 \%$ & $8 \%$ & $82.8 \%$ & $82.8 \%$ & ${ }^{244} \mathrm{Cm}$ & $21.4 \%$ & $21.4 \%$ & & $5 \%$ & $.5 \%$ \\
\hline${ }^{246} \mathrm{Cm}$ & $167.4 \%$ & $167.4 \%$ & $167.4 \%$ & $167.4 \%$ & $167.3 \%$ & ${ }^{246} \mathrm{Cm}$ & $32.0 \%$ & $32.0 \%$ & $.0 \%$ & $0 \%$ & $.0 \%$ \\
\hline${ }^{134} \mathrm{Cs}$ & $40.6 \%$ & $40.6 \%$ & $40.6 \%$ & $40.6 \%$ & $40.6 \%$ & ${ }^{134} \mathrm{Cs}$ & $30.2 \%$ & $30.2 \%$ & $1 \%$ & $1 \%$ & $.1 \%$ \\
\hline${ }^{154} \mathrm{Eu}$ & $36.9 \%$ & $36.9 \%$ & $36.9 \%$ & $36.9 \%$ & $36.9 \%$ & ${ }^{154} \mathrm{Eu}$ & $40.9 \%$ & $40.9 \%$ & $3 \%$ & $9 \%$ & $.9 \%$ \\
\hline${ }^{144} \mathrm{Pr}$ & $0.3 \%$ & $0.3 \%$ & $0.4 \%$ & $0.4 \%$ & $0.4 \%$ & ${ }^{144} \operatorname{Pr}$ & $4.4 \%$ & $4.5 \%$ & $4.5 \%$ & $.5 \%$ & $4.5 \%$ \\
\hline${ }^{238} \mathrm{Pu}$ & $74.7 \%$ & $74.7 \%$ & $74.5 \%$ & $74.3 \%$ & $72.7 \%$ & ${ }^{238} \mathrm{Pu}$ & $67.4 \%$ & $67.4 \%$ & $67.2 \%$ & $66.9 \%$ & $5.1 \%$ \\
\hline${ }^{239} \mathrm{Pu}$ & $8.5 \%$ & $8.4 \%$ & $8.3 \%$ & $8.3 \%$ & $8.3 \%$ & ${ }^{239} \mathrm{Pu}$ & $20.5 \%$ & $20.5 \%$ & $20.2 \%$ & $20.0 \%$ & $20.0 \%$ \\
\hline${ }^{240} \mathrm{Pu}$ & $11.9 \%$ & $11.9 \%$ & $11.9 \%$ & $11.9 \%$ & $12.1 \%$ & ${ }^{240} \mathrm{Pu}$ & $8.0 \%$ & $8.0 \%$ & $3.0 \%$ & $.0 \%$ & $.1 \%$ \\
\hline${ }^{242} \mathrm{Pu}$ & $32.6 \%$ & $32.6 \%$ & $32.6 \%$ & $32.6 \%$ & $32.6 \%$ & ${ }^{242} \mathrm{Pu}$ & $5.6 \%$ & $5.6 \%$ & $5.6 \%$ & $5.6 \%$ & $5.6 \%$ \\
\hline${ }^{106} \mathrm{Rh}$ & $7.5 \%$ & $9.0 \%$ & $9.0 \%$ & $9.0 \%$ & $9.0 \%$ & ${ }^{106} \mathrm{Rh}$ & $-7.3 \%$ & $-4.7 \%$ & $-4.7 \%$ & $-4.7 \%$ & $-4.7 \%$ \\
\hline${ }^{90} \mathrm{Y}$ & $31.4 \%$ & $31.3 \%$ & $31.4 \%$ & $31.5 \%$ & $31.5 \%$ & ${ }^{90} \mathrm{Y}$ & $39.5 \%$ & $39.5 \%$ & $40.3 \%$ & $40.6 \%$ & $40.6 \%$ \\
\hline
\end{tabular}




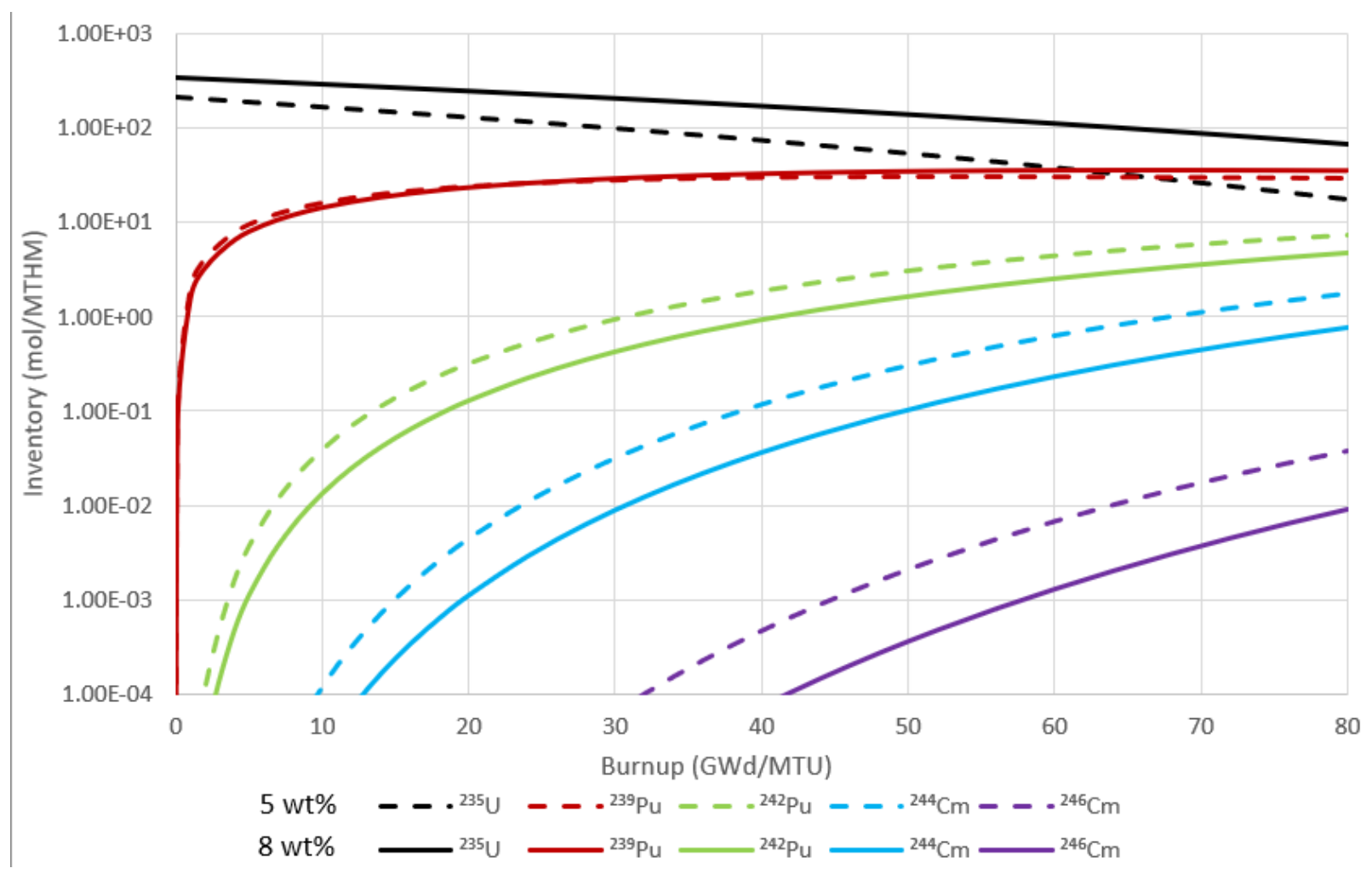

Figure 49. In-core abundances for isotopes in the activation chain for ${ }^{244} \mathrm{Cm}$ and ${ }^{246} \mathrm{Cm}$.

Neutron emitters are important in cask shielding applications, and the appearance of additional spontaneous fission neutron emitters could carry implications for shielding analyses. In the cases evaluated, spontaneous fission neutron emitters such as ${ }^{244} \mathrm{Cm}$ produced about 50 times more neutrons that $\alpha, n$ sources. To verify that no additional spontaneous fission source appeared from the set of isotopes that SCALE computes, the difference in spontaneous fission source intensity between the $80 \mathrm{GWd} / \mathrm{MTU}$ $8 \mathrm{wt} \%$ case and the $60 \mathrm{GWd} / \mathrm{MTU} 5 \mathrm{wt} \%$ case is evaluated in Table 14. These differences were then taken as a percentage of the total spontaneous fission neutron production listed in the $60 \mathrm{GWd} / \mathrm{MTU} 5$ $\mathrm{wt} \%$ case for the depletion time and are listed in Table 14 . It is clearly seen that ${ }^{244} \mathrm{Cm}$ is the main isotope that changes the spontaneous neutron emission source substantially for the timescales in question.

Isotopes with relative differences under $0.01 \%$ are not listed. Despite the $32 \%$ increase in ${ }^{246} \mathrm{Cm}$ composition in the $80 \mathrm{GWd} / \mathrm{MTU} 8 \mathrm{wt} \%$ case over the reference $60 \mathrm{GWd} / \mathrm{MTU} 5 \mathrm{wt} \%$ case seen in Table 13 , this isotope should not substantially affect the neutron dose. Furthermore, no other new spontaneous fission isotopes become prominent. ${ }^{242} \mathrm{Cm}$ and ${ }^{244} \mathrm{Cm}$ increase in activity, and few actinides heavier than ${ }^{244} \mathrm{Cm}$ are produced because ${ }^{245} \mathrm{Cm}$ has a high neutron-induced fission probability. 
Table 14. Relative difference in SF neutron emission on total SF neutron emission basis for time point $80 \mathrm{GWd} / \mathrm{MTU} 8 \mathrm{wt} \%$ vs $60 \mathrm{GWd} / \mathrm{MTU} 5 \mathrm{w} \%$

\begin{tabular}{|c|c|c|c|c|c|}
\hline \multicolumn{6}{|c|}{$\begin{array}{c}\text { 20 GWd/MTU burnup and } \\
\text { 3\% enrichment increase } \\
5 \mathrm{wt} \% \text { at } 60 \mathrm{GWd} / \mathrm{MTU}(\mathrm{ref}) \rightarrow 8 \text { at } 80\end{array}$} \\
\hline & $0 \mathrm{~s}$ & $30 \mathrm{~min}$ & 5 days & 25 days & 500 days \\
\hline${ }^{244} \mathrm{Cm}$ & $15.12 \%$ & $15.12 \%$ & $15.18 \%$ & $15.52 \%$ & $20.03 \%$ \\
\hline${ }^{242} \mathrm{Cm}$ & $7.68 \%$ & $7.68 \%$ & $7.58 \%$ & $7.14 \%$ & $1.29 \%$ \\
\hline${ }^{252} \mathrm{Cf}$ & $0.65 \%$ & $0.65 \%$ & $0.65 \%$ & $0.66 \%$ & $0.63 \%$ \\
\hline${ }^{246} \mathrm{Cm}$ & $0.21 \%$ & $0.21 \%$ & $0.21 \%$ & $0.22 \%$ & $0.29 \%$ \\
\hline${ }^{238} \mathrm{Pu}$ & $0.04 \%$ & $0.04 \%$ & $0.04 \%$ & $0.04 \%$ & $0.06 \%$ \\
\hline${ }^{240} \mathrm{Pu}$ & $0.01 \%$ & $0.01 \%$ & $0.01 \%$ & $0.01 \%$ & $0.01 \%$ \\
\hline${ }^{250} \mathrm{Cf}$ & $0.01 \%$ & $0.01 \%$ & $0.01 \%$ & $0.01 \%$ & $0.01 \%$ \\
\hline${ }^{254} \mathrm{Cf}$ & $0.01 \%$ & $0.01 \%$ & $0.01 \%$ & $0.01 \%$ & $0.00 \%$ \\
\hline
\end{tabular}

\subsection{ISOTOPES FOR CRITICALITY}

The top 10 actinide and the top 10 fission product isotopes for criticality 5 years after discharge as listed in NUREG/CR 6700 [8] were used to examine criticality. These are similar to the results shown in Section 3.3. However, the Section 3.3 list includes ${ }^{135} \mathrm{Xe}$. Due to its short half-life, it was not included in NUREG/CR-6700.

Table 15 shows relative differences between isotope masses for each pair of cases on a total mass basis. The relative differences are computed as

$$
\frac{M_{i}-M_{i, r e f}}{M_{\text {ref }}}-1
$$

In Table 15 and Table 16, the uranium isotopes and ${ }^{239} \mathrm{Pu}$ have the largest mass changes. The uranium isotopes are not color coded by value because their relative changes are so large that they eclipse all other changes. In the case of enrichment change, the ${ }^{239} \mathrm{Pu}$ concentration changes little because it has reached saturation, so its fission rate is approximately equal to its creation rate. In the upper right portion of Table $15,{ }^{239} \mathrm{Pu}$ actually decreases slightly because its fission rate increases as the ${ }^{235} \mathrm{U}$ is burned out. 
Table 15. Relative mass difference for criticality isotopes as ppm of total $\mathrm{UO}_{2}$ mass for separate enrichment or burnup increases

(Isotopes are color-coded yellow for transuranic actinides, gray for uranium isotopes, green for ordinary fission products, and black for fission product neutron poisons.)

\begin{tabular}{|c|c|c|c|c|c|c|c|c|c|c|c|}
\hline \multicolumn{6}{|c|}{$\begin{array}{c}\text { 3\% enrichment increase } \\
5 \mathrm{wt} \% \text { (ref) } \rightarrow 8 \text { at } 60 \mathrm{GWd} / \mathrm{MTU}\end{array}$} & \multicolumn{6}{|c|}{$\begin{array}{l}20 \mathrm{GWd} / \mathrm{MTU} \text { burnup increase } \\
60 \mathrm{GWd} / \mathrm{MTU} \text { (ref) } \rightarrow 80 \text { for } 8 \mathrm{w} \%\end{array}$} \\
\hline Isotope & $0 \mathrm{~s}$ & $30 \mathrm{~min}$ & 5 days & 25 days & 500 days & Isotope & $\mathbf{0 s}$ & 30 min & 5 days & 25 days & 500 days \\
\hline${ }^{243} \mathrm{Am}$ & -120 & -120 & -120 & -120 & -120 & ${ }^{243} \mathrm{Am}$ & 140 & 140 & 140 & 140 & 140 \\
\hline${ }^{237} \mathrm{~Np}$ & 110 & 110 & 110 & 110 & 110 & ${ }^{237} \mathbf{N p}$ & 320 & 320 & 320 & 330 & 330 \\
\hline${ }^{239} \mathrm{Pu}$ & 1400 & 1400 & 1300 & 1300 & 1300 & ${ }^{239} \mathrm{Pu}$ & -68 & -69 & -63 & -60 & -61 \\
\hline${ }^{240} \mathrm{Pu}$ & -360 & -360 & -360 & -370 & -370 & ${ }^{240} \mathrm{Pu}$ & 580 & 580 & 580 & 580 & 590 \\
\hline${ }^{241} \mathrm{Pu}$ & -69 & -69 & -68 & -68 & -63 & ${ }^{241} \mathbf{P u}$ & 450 & 450 & 450 & 450 & 420 \\
\hline${ }^{242} \mathrm{Pu}$ & -420 & -420 & -420 & -420 & -420 & ${ }^{242} \mathbf{P u}$ & 480 & 480 & 480 & 480 & 480 \\
\hline${ }^{234} \mathrm{U}$ & 180 & 180 & 180 & 180 & 180 & ${ }^{234} \mathrm{U}$ & -71 & -71 & -71 & -71 & -67 \\
\hline${ }^{235} \mathrm{U}$ & 16000 & 16000 & 16000 & 16000 & 16000 & ${ }^{235} \mathrm{U}$ & -9100 & -9100 & -9100 & -9100 & -9100 \\
\hline${ }^{236} \mathbf{U}$ & 3000 & 3000 & 3000 & 3000 & 3000 & ${ }^{236} \mathbf{U}$ & 1200 & 1200 & 1200 & 1200 & 1200 \\
\hline${ }^{238} \mathrm{U}$ & -20000 & -20000 & -20000 & -20000 & -20000 & ${ }^{238} \mathbf{U}$ & -12000 & -12000 & -12000 & -12000 & -12000 \\
\hline${ }^{133} \mathrm{Cs}$ & 96 & 95 & 95 & 96 & 96 & ${ }^{133} \mathrm{Cs}$ & 430 & 430 & 430 & 430 & 430 \\
\hline${ }^{153} \mathbf{E u}$ & -12 & -12 & -12 & -12 & -12 & ${ }^{153} \mathbf{E u}$ & 55 & 55 & 55 & 55 & 55 \\
\hline${ }^{155} \mathrm{Gd}$ & 0.077 & 0.077 & 0.073 & 0.055 & -0.33 & ${ }^{155} \mathrm{Gd}$ & 0.086 & 0.086 & 0.099 & 0.15 & 1.3 \\
\hline${ }^{143} \mathrm{Nd}$ & 260 & 260 & 260 & 260 & 260 & ${ }^{143} \mathrm{Nd}$ & 220 & 220 & 220 & 220 & 220 \\
\hline${ }^{145} \mathrm{Nd}$ & 88 & 88 & 89 & 89 & 89 & ${ }^{145} \mathrm{Nd}$ & 260 & 260 & 260 & 260 & 260 \\
\hline${ }^{103} \mathrm{Rh}$ & 9.0 & 9.0 & 8.5 & 6.9 & 2.8 & ${ }^{103} \mathrm{Rh}$ & 130 & 130 & 130 & 130 & 130 \\
\hline${ }^{147} \mathrm{Sm}$ & 27 & 27 & 27 & 27 & 39 & ${ }^{147} \mathrm{Sm}$ & 31 & 31 & 31 & 31 & 29 \\
\hline${ }^{149} \mathrm{Sm}$ & 1.9 & 1.9 & 1.8 & 1.8 & 1.8 & ${ }^{149} \mathrm{Sm}$ & -0.60 & -0.60 & -0.54 & -0.52 & -0.52 \\
\hline${ }^{151} \mathrm{Sm}$ & 6.5 & 6.5 & 6.5 & 6.5 & 6.4 & ${ }^{151} \mathrm{Sm}$ & 1.1 & 1.2 & 1.2 & 1.2 & 1.2 \\
\hline${ }^{152} \mathrm{Sm}$ & 1.1 & 1.1 & 1.1 & 1.1 & 1.1 & ${ }^{152} \mathrm{Sm}$ & 22 & 22 & 22 & 22 & 22 \\
\hline${ }^{99} \mathrm{Tc}$ & 61 & 61 & 60 & 61 & 61 & ${ }^{99} \mathrm{Tc}$ & 320 & 320 & 320 & 320 & 320 \\
\hline${ }^{131} \mathrm{Xe}$ & 58 & 58 & 58 & 58 & 58 & ${ }^{131} \mathrm{Xe}$ & 95 & 95 & 95 & 95 & 95 \\
\hline${ }^{135} \mathrm{Xe}$ & 0.11 & 0.1 & $1.3 \mathrm{E}-05$ & $2.1 \mathrm{E}-21$ & 0 & ${ }^{135} \mathrm{Xe}$ & -0.04 & -0.039 & $-6 \mathrm{E}-06$ & $-9 \mathrm{E}-22$ & 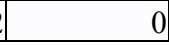 \\
\hline
\end{tabular}


Table 16. Mass difference for criticality isotopes as ppm of total $\mathrm{UO}_{2}$ mass for simultaneously increasing burnup and enrichment

(Isotopes are color-coded yellow for transuranic actinides, grey for uranium isotopes, green for ordinary fission products, and black for fission product neutron poisons.)

\begin{tabular}{|c|c|c|c|c|c|c|c|c|c|c|c|}
\hline & $\begin{array}{r}20 \\
\mathbf{1}\end{array}$ & $\begin{array}{l}\mathbf{G W d} / \mathrm{M} \\
5 \% \text { enric } \\
60 \mathrm{GWd} /\end{array}$ & $\begin{array}{l}\text { TU burnu } \\
\text { hment inc } \\
\text { MTU (ref) }\end{array}$ & $\begin{array}{l}\text { p and } \\
\text { rease } \\
\rightarrow 6.5 \text { at } 8\end{array}$ & & & $\begin{array}{r}30 \\
5 \mathrm{wt} \% \text { at }\end{array}$ & $\begin{array}{l}\text { GWd/M } \\
\% \text { enrich } \\
60 \mathrm{GWd}\end{array}$ & $\begin{array}{l}\text { TU burnu } \\
\text { iment incr } \\
\text { /MTU (ref }\end{array}$ & $\begin{array}{l}\text { ip and } \\
\text { rease } \\
\text { f) } \rightarrow 8 \text { at } 8\end{array}$ & \\
\hline Isotope & $0 \mathrm{~s}$ & $30 \mathrm{~min}$ & 5 days & 25 days & 500 days & Isotope & $0 \mathrm{~s}$ & $30 \mathrm{~min}$ & 5 days & 25 days & 500 days \\
\hline${ }^{243} \mathrm{Am}$ & 110 & 110 & 110 & 110 & 110 & ${ }^{243} \mathrm{Am}$ & 26 & 26 & 26 & 26 & 26 \\
\hline${ }^{237} \mathrm{~Np}$ & 340 & 340 & 340 & 340 & 340 & ${ }^{237} \mathbf{N p}$ & 430 & 430 & 430 & 440 & 440 \\
\hline${ }^{239} \mathrm{Pu}$ & 530 & 530 & 530 & 530 & 530 & ${ }^{239} \mathrm{Pu}$ & 1300 & 1300 & 1300 & 1300 & 1300 \\
\hline${ }^{240} \mathrm{Pu}$ & 320 & 320 & 320 & 320 & 330 & ${ }^{240} \mathrm{Pu}$ & 220 & 220 & 220 & 220 & 220 \\
\hline${ }^{241} \mathrm{Pu}$ & 330 & 330 & 330 & 330 & 310 & ${ }^{241} \mathrm{Pu}$ & 390 & 390 & 390 & 380 & 360 \\
\hline${ }^{242} \mathrm{Pu}$ & 320 & 320 & 320 & 320 & 320 & ${ }^{242} \mathrm{Pu}$ & 54 & 54 & 54 & 54 & 54 \\
\hline${ }^{234} \mathrm{U}$ & 29 & 29 & 29 & 30 & 33 & ${ }^{234} \mathbf{U}$ & 110 & 110 & 110 & 110 & 120 \\
\hline${ }^{235} \mathrm{U}$ & 170 & 170 & 170 & 170 & 170 & ${ }^{235} \mathbf{U}$ & 6400 & 6400 & 6400 & 6400 & 6400 \\
\hline${ }^{236} \mathrm{U}$ & 2300 & 2300 & 2300 & 2300 & 2300 & ${ }^{236} \mathbf{U}$ & 4100 & 4100 & 4100 & 4100 & 4100 \\
\hline${ }^{238} \mathrm{U}$ & -23000 & -23000 & -23000 & -23000 & -23000 & ${ }^{238} \mathbf{U}$ & -32000 & -32000 & -32000 & -32000 & -32000 \\
\hline${ }^{133} \mathrm{Cs}$ & 450 & 450 & 450 & 450 & 450 & ${ }^{133} \mathrm{Cs}$ & 530 & 530 & 530 & 530 & 530 \\
\hline${ }^{153} \mathbf{E u}$ & 46 & 46 & 47 & 47 & 47 & ${ }^{153} \mathbf{E u}$ & 44 & 44 & 44 & 44 & 44 \\
\hline${ }^{155} \mathrm{Gd}$ & 0.1 & 0.1 & 0.11 & 0.15 & 1 & ${ }^{155} \mathrm{Gd}$ & 0.16 & 0.16 & 0.17 & 0.21 & 0.97 \\
\hline${ }^{143} \mathrm{Nd}$ & 300 & 300 & 300 & 300 & 300 & ${ }^{143} \mathrm{Nd}$ & 480 & 480 & 480 & 480 & 480 \\
\hline${ }^{145} \mathrm{Nd}$ & 290 & 290 & 290 & 290 & 290 & ${ }^{145} \mathrm{Nd}$ & 350 & 350 & 350 & 350 & 350 \\
\hline${ }^{103} \mathrm{Rh}$ & 120 & 120 & 120 & 120 & 120 & ${ }^{103} \mathrm{Rh}$ & 140 & 140 & 140 & 140 & 130 \\
\hline${ }^{147} \mathrm{Sm}$ & 38 & 38 & 38 & 38 & 42 & ${ }^{147} \mathrm{Sm}$ & 58 & 58 & 58 & 58 & 68 \\
\hline${ }^{149} \mathrm{Sm}$ & 0.43 & 0.43 & 0.44 & 0.44 & 0.44 & ${ }^{149} \mathrm{Sm}$ & 1.3 & 1.3 & 1.3 & 1.3 & 1.3 \\
\hline${ }^{151} \mathrm{Sm}$ & 4.3 & 4.3 & 4.3 & 4.3 & 4.3 & ${ }^{151} \mathrm{Sm}$ & 7.7 & 7.7 & 7.7 & 7.6 & 7.6 \\
\hline${ }^{152} \mathrm{Sm}$ & 22 & 22 & 22 & 22 & 22 & ${ }^{152} \mathrm{Sm}$ & 23 & 23 & 23 & 23 & 23 \\
\hline${ }^{99} \mathrm{Tc}$ & 340 & 340 & 340 & 340 & 340 & ${ }^{99} \mathrm{Tc}$ & 380 & 380 & 380 & 380 & 380 \\
\hline${ }^{131} \mathrm{Xe}$ & 110 & 110 & 110 & 110 & 110 & ${ }^{131} \mathrm{Xe}$ & 150 & 150 & 150 & 150 & 150 \\
\hline${ }^{135} \mathrm{Xe}$ & 0.018 & 0.017 & $1.4 \mathrm{E}-06$ & $2.2 \mathrm{E}-22$ & 0 & ${ }^{135} \mathrm{Xe}$ & 0.067 & 0.064 & 7.6E-06 & $1.2 \mathrm{E}-21$ & 0 \\
\hline
\end{tabular}

The relative changes in mass for criticality isotopes are shown in Table 17 and Table 18 on an individual isotope basis. The relative differences are computed as

$$
\frac{M_{i}}{M_{i, r e f}}-1
$$

As shown in Table 17, varying burnup or initial enrichment alone creates large relative changes in isotopic content for heavier actinides such as ${ }^{243} \mathrm{Am}$ and ${ }^{242} \mathrm{Pu}$. When increasing enrichment with burnup, the competing effects mostly cancel out for the heavier transuranics. This is because they are the products of multiple neutron absorptions, so their abundance increases with burnup. For a given burnup, increased enrichment results in less overall neutron fluence, so neutron absorption products decrease with increasing enrichment. 
Table 17. Relative mass difference for criticality isotopes on isotope basis at time point

(Isotopes are color-coded yellow for transuranic actinides, gray for uranium isotopes, green for ordinary fission products, and black for fission product neutron poisons.)

\begin{tabular}{|c|c|c|c|c|c|c|c|c|c|c|c|}
\hline \multicolumn{6}{|c|}{$\begin{array}{c}\text { 3\% enrichment increase } \\
5 \mathrm{wt} \% \text { (ref) } \rightarrow 8 \text { at } 60 \mathrm{GWd} / \mathrm{MTU}\end{array}$} & \multicolumn{6}{|c|}{$\begin{array}{l}20 \mathrm{GWd} / \mathrm{MTU} \text { burnup increase } \\
60 \mathrm{GWd} / \mathrm{MTU} \text { (ref) } \rightarrow 80 \text { for } 8 \mathrm{w} \%\end{array}$} \\
\hline \begin{tabular}{|l|} 
Isotope \\
\end{tabular} & $0 \mathrm{~s}$ & $30 \mathrm{~min}$ & 5 days & 25 days & 500 days & Isotope & $\mathbf{0 s}$ & 30 min & 5 days & 25 days & 500 days \\
\hline${ }^{243} \mathrm{Am}$ & $-51 \%$ & $-51 \%$ & $-51 \%$ & $-51 \%$ & $-51 \%$ & ${ }^{243} \mathrm{Am}$ & $129 \%$ & $129 \%$ & $129 \%$ & $129 \%$ & $129 \%$ \\
\hline${ }^{237} \mathrm{~Np}$ & $14 \%$ & $14 \%$ & $14 \%$ & $14 \%$ & $14 \%$ & ${ }^{237} \mathrm{~Np}$ & $35 \%$ & $35 \%$ & $35 \%$ & $35 \%$ & $35 \%$ \\
\hline${ }^{239} \mathrm{Pu}$ & $22 \%$ & $22 \%$ & $21 \%$ & $21 \%$ & $21 \%$ & ${ }^{239} \mathrm{Pu}$ & $-1 \%$ & $-1 \%$ & $-1 \%$ & $-1 \%$ & $-1 \%$ \\
\hline${ }^{240} \mathrm{Pu}$ & $-13 \%$ & $-13 \%$ & $-13 \%$ & $-14 \%$ & $-14 \%$ & ${ }^{240} \mathrm{Pu}$ & $25 \%$ & $25 \%$ & $25 \%$ & $25 \%$ & $25 \%$ \\
\hline${ }^{241} \mathrm{Pu}$ & $-3 \%$ & $-3 \%$ & $-3 \%$ & $-3 \%$ & $-3 \%$ & ${ }^{241} \mathrm{Pu}$ & $24 \%$ & $24 \%$ & $24 \%$ & $24 \%$ & $24 \%$ \\
\hline${ }^{242} \mathrm{Pu}$ & $-44 \%$ & $-44 \%$ & $-44 \%$ & $-44 \%$ & $-44 \%$ & ${ }^{242} \mathrm{Pu}$ & $88 \%$ & $88 \%$ & $88 \%$ & $88 \%$ & $88 \%$ \\
\hline${ }^{234} \mathrm{U}$ & $101 \%$ & $101 \%$ & $101 \%$ & $101 \%$ & $98 \%$ & ${ }^{234} \mathrm{U}$ & $-19 \%$ & $-19 \%$ & $-19 \%$ & $-19 \%$ & $-18 \%$ \\
\hline${ }^{235} \mathrm{U}$ & $198 \%$ & $198 \%$ & $198 \%$ & $198 \%$ & $198 \%$ & ${ }^{235} \mathrm{U}$ & $-39 \%$ & $-39 \%$ & $-39 \%$ & $-39 \%$ & $-39 \%$ \\
\hline${ }^{236} \mathrm{U}$ & $47 \%$ & $47 \%$ & $47 \%$ & $47 \%$ & $47 \%$ & ${ }^{236} \mathbf{U}$ & $12 \%$ & $12 \%$ & $12 \%$ & $12 \%$ & $13 \%$ \\
\hline${ }^{238} \mathrm{U}$ & $-2 \%$ & $-2 \%$ & $-2 \%$ & $-2 \%$ & $-2 \%$ & ${ }^{238} \mathrm{U}$ & $-2 \%$ & $-2 \%$ & $-2 \%$ & $-2 \%$ & $-2 \%$ \\
\hline${ }^{133} \mathrm{Cs}$ & $6 \%$ & $6 \%$ & $6 \%$ & $6 \%$ & $6 \%$ & ${ }^{133} \mathrm{Cs}$ & $24 \%$ & $24 \%$ & $24 \%$ & $24 \%$ & $24 \%$ \\
\hline${ }^{153} \mathbf{E u}$ & $-6 \%$ & $-6 \%$ & $-7 \%$ & $-7 \%$ & $-7 \%$ & ${ }^{153} \mathbf{E u}$ & $33 \%$ & $33 \%$ & $33 \%$ & $33 \%$ & $33 \%$ \\
\hline${ }^{155} \mathrm{Gd}$ & $50 \%$ & $50 \%$ & $39 \%$ & $18 \%$ & $-11 \%$ & ${ }^{155} \mathrm{Gd}$ & $37 \%$ & $37 \%$ & $39 \%$ & $42 \%$ & $50 \%$ \\
\hline${ }^{143} \mathrm{Nd}$ & $23 \%$ & $23 \%$ & $22 \%$ & $22 \%$ & $22 \%$ & ${ }^{143} \mathrm{Nd}$ & $16 \%$ & $16 \%$ & $16 \%$ & $16 \%$ & $15 \%$ \\
\hline${ }^{145} \mathrm{Nd}$ & $9 \%$ & $9 \%$ & $9 \%$ & $9 \%$ & $9 \%$ & ${ }^{145} \mathrm{Nd}$ & $24 \%$ & $24 \%$ & $24 \%$ & $24 \%$ & $24 \%$ \\
\hline${ }^{103} \mathrm{Rh}$ & $1 \%$ & $1 \%$ & $1 \%$ & $1 \%$ & $0 \%$ & ${ }^{103} \mathrm{Rh}$ & $20 \%$ & $20 \%$ & $20 \%$ & $20 \%$ & $20 \%$ \\
\hline${ }^{147} \mathrm{Sm}$ & $24 \%$ & $25 \%$ & $24 \%$ & $24 \%$ & $23 \%$ & ${ }^{147} \mathrm{Sm}$ & $23 \%$ & $23 \%$ & $23 \%$ & $22 \%$ & $14 \%$ \\
\hline${ }^{149} \mathrm{Sm}$ & $65 \%$ & $65 \%$ & $45 \%$ & $42 \%$ & $42 \%$ & ${ }^{149} \mathrm{Sm}$ & $-12 \%$ & $-12 \%$ & $-9 \%$ & $-9 \%$ & $-9 \%$ \\
\hline${ }^{151} \mathrm{Sm}$ & $37 \%$ & $37 \%$ & $37 \%$ & $37 \%$ & $37 \%$ & ${ }^{151} \mathrm{Sm}$ & $5 \%$ & $5 \%$ & $5 \%$ & $5 \%$ & $5 \%$ \\
\hline${ }^{152} \mathrm{Sm}$ & $1 \%$ & $1 \%$ & $1 \%$ & $1 \%$ & $1 \%$ & ${ }^{152} \mathrm{Sm}$ & $16 \%$ & $16 \%$ & $16 \%$ & $16 \%$ & $16 \%$ \\
\hline${ }^{99} \mathrm{Tc}$ & $5 \%$ & $5 \%$ & $5 \%$ & $5 \%$ & $5 \%$ & ${ }^{99} \mathrm{Tc}$ & $26 \%$ & $26 \%$ & $26 \%$ & $25 \%$ & $25 \%$ \\
\hline${ }^{131} \mathrm{Xe}$ & $10 \%$ & $10 \%$ & $10 \%$ & $10 \%$ & $10 \%$ & ${ }^{131} \mathrm{Xe}$ & $15 \%$ & $15 \%$ & $15 \%$ & $15 \%$ & $15 \%$ \\
\hline${ }^{135} \mathrm{Xe}$ & $49 \%$ & $44 \%$ & $6 \%$ & $6 \%$ & - & ${ }^{135} \mathrm{Xe}$ & $-12 \%$ & $-11 \%$ & $-2 \%$ & $-2 \%$ & - \\
\hline
\end{tabular}


Table 18. Relative mass difference for criticality isotopes on isotope mass basis at time point

(Isotopes are color-coded yellow for transuranic actinides, gray for uranium isotopes, green for ordinary fission products, and black for fission product neutron poisons.)

\begin{tabular}{|c|c|c|c|c|c|c|c|c|c|c|c|}
\hline & $\begin{array}{r}2 \\
1 \\
\mathrm{wt}^{2} \% \mathrm{a}\end{array}$ & $\begin{array}{l}0 \mathrm{GWd} / \mathrm{M} \\
1.5 \% \text { enric } \\
60 \mathrm{GWd}\end{array}$ & $\begin{array}{l}\text { ITU burn } \\
\text { chment in } \\
\text { /MTU (re }\end{array}$ & $\begin{array}{l}\text { nup and } \\
\text { ncrease } \\
\text { ef) } \rightarrow 6.5 \text { at }\end{array}$ & it 80 & & $\begin{array}{r}20 \\
3 \\
5 w t \% a\end{array}$ & $\begin{array}{l}\text { GWd/MT } \\
\% \text { enrich } \\
\text { th } 60 \mathrm{GWd} /\end{array}$ & $\begin{array}{l}\text { TU burn } \\
\text { iment inc } \\
\mathrm{l} / \mathrm{MTU} \text { (re }\end{array}$ & $\begin{array}{l}\text { up and } \\
\text { crease } \\
\text { ef) } \rightarrow 8 \text { at }\end{array}$ & \\
\hline Isotope & $0 \mathrm{~s}$ & $30 \mathrm{~min}$ & 5 days & 25 days & 500 days & Isotope & $0 \mathrm{~s}$ & $30 \mathrm{~min}$ & 5 days & 25 days & 500 days \\
\hline${ }^{243} \mathrm{Am}$ & $47 \%$ & $47 \%$ & $47 \%$ & $47 \%$ & $47 \%$ & ${ }^{243} \mathrm{Am}$ & $11 \%$ & $11 \%$ & $11 \%$ & $11 \%$ & $11 \%$ \\
\hline${ }^{237} \mathbf{N p}$ & $42 \%$ & $42 \%$ & $42 \%$ & $42 \%$ & $42 \%$ & ${ }^{237} \mathrm{~Np}$ & $54 \%$ & $54 \%$ & $54 \%$ & $54 \%$ & $54 \%$ \\
\hline${ }^{239} \mathrm{Pu}$ & $8 \%$ & $8 \%$ & $8 \%$ & $8 \%$ & $8 \%$ & ${ }^{239} \mathrm{Pu}$ & $21 \%$ & $21 \%$ & $20 \%$ & $20 \%$ & $20 \%$ \\
\hline${ }^{240} \mathrm{Pu}$ & $12 \%$ & $12 \%$ & $12 \%$ & $12 \%$ & $12 \%$ & ${ }^{240} \mathrm{Pu}$ & $8 \%$ & $8 \%$ & $8 \%$ & $8 \%$ & $8 \%$ \\
\hline${ }^{241} \mathrm{Pu}$ & $17 \%$ & $17 \%$ & $17 \%$ & $17 \%$ & $17 \%$ & ${ }^{241} \mathrm{Pu}$ & $20 \%$ & $20 \%$ & $20 \%$ & $20 \%$ & $20 \%$ \\
\hline${ }^{242} \mathrm{Pu}$ & $33 \%$ & $33 \%$ & $33 \%$ & $33 \%$ & $33 \%$ & ${ }^{242} \mathbf{P u}$ & $6 \%$ & $6 \%$ & $6 \%$ & $6 \%$ & $6 \%$ \\
\hline${ }^{234} \mathrm{U}$ & $16 \%$ & $16 \%$ & $16 \%$ & $16 \%$ & $18 \%$ & ${ }^{234} \mathrm{U}$ & $62 \%$ & $62 \%$ & $62 \%$ & $62 \%$ & $63 \%$ \\
\hline${ }^{235} \mathrm{U}$ & $2 \%$ & $2 \%$ & $2 \%$ & $2 \%$ & $2 \%$ & ${ }^{235} \mathrm{U}$ & $82 \%$ & $82 \%$ & $82 \%$ & $82 \%$ & $82 \%$ \\
\hline${ }^{236} \mathbf{U}$ & $36 \%$ & $36 \%$ & $36 \%$ & $36 \%$ & $36 \%$ & ${ }^{236} \mathrm{U}$ & $65 \%$ & $65 \%$ & $65 \%$ & $65 \%$ & $65 \%$ \\
\hline${ }^{238} \mathrm{U}$ & $-3 \%$ & $-3 \%$ & $-3 \%$ & $-3 \%$ & $-3 \%$ & ${ }^{238} \mathrm{U}$ & $-4 \%$ & $-4 \%$ & $-4 \%$ & $-4 \%$ & $-4 \%$ \\
\hline${ }^{133} \mathrm{Cs}$ & $27 \%$ & $27 \%$ & $27 \%$ & $27 \%$ & $27 \%$ & ${ }^{133} \mathrm{Cs}$ & $32 \%$ & $32 \%$ & $31 \%$ & $31 \%$ & $31 \%$ \\
\hline${ }^{153} \mathbf{E u}$ & $26 \%$ & $26 \%$ & $26 \%$ & $26 \%$ & $26 \%$ & ${ }^{153} \mathbf{E u}$ & $24 \%$ & $24 \%$ & $24 \%$ & $24 \%$ & $24 \%$ \\
\hline${ }^{155} \mathrm{Gd}$ & $65 \%$ & $65 \%$ & $60 \%$ & $50 \%$ & $35 \%$ & ${ }^{155} \mathbf{G d}$ & $106 \%$ & $106 \%$ & $93 \%$ & $68 \%$ & $33 \%$ \\
\hline${ }^{143} \mathrm{Nd}$ & $26 \%$ & $26 \%$ & $26 \%$ & $26 \%$ & $26 \%$ & ${ }^{143} \mathrm{Nd}$ & $42 \%$ & $42 \%$ & $42 \%$ & $41 \%$ & $41 \%$ \\
\hline${ }^{145} \mathrm{Nd}$ & $28 \%$ & $28 \%$ & $28 \%$ & $28 \%$ & $28 \%$ & ${ }^{145} \mathrm{Nd}$ & $34 \%$ & $34 \%$ & $34 \%$ & $34 \%$ & $34 \%$ \\
\hline${ }^{103} \mathrm{Rh}$ & $20 \%$ & $20 \%$ & $19 \%$ & $19 \%$ & $18 \%$ & ${ }^{103} \mathbf{R h}$ & $22 \%$ & $22 \%$ & $22 \%$ & $21 \%$ & $20 \%$ \\
\hline${ }^{147} \mathrm{Sm}$ & $35 \%$ & $35 \%$ & $35 \%$ & $34 \%$ & $24 \%$ & ${ }^{147} \mathrm{Sm}$ & $53 \%$ & $53 \%$ & $53 \%$ & $52 \%$ & $40 \%$ \\
\hline${ }^{149} \mathrm{Sm}$ & $15 \%$ & $14 \%$ & $11 \%$ & $10 \%$ & $10 \%$ & ${ }^{149} \mathrm{Sm}$ & $45 \%$ & $45 \%$ & $32 \%$ & $29 \%$ & $29 \%$ \\
\hline${ }^{151} \mathrm{Sm}$ & $25 \%$ & $25 \%$ & $25 \%$ & $24 \%$ & $24 \%$ & ${ }^{151} \mathrm{Sm}$ & $44 \%$ & $44 \%$ & $43 \%$ & $43 \%$ & $43 \%$ \\
\hline${ }^{152} \mathrm{Sm}$ & $16 \%$ & $17 \%$ & $17 \%$ & $17 \%$ & $17 \%$ & ${ }^{152} \mathrm{Sm}$ & $17 \%$ & $17 \%$ & $17 \%$ & $17 \%$ & $17 \%$ \\
\hline${ }^{99} \mathrm{Tc}$ & $28 \%$ & $28 \%$ & $28 \%$ & $28 \%$ & $28 \%$ & ${ }^{99} \mathrm{Tc}$ & $32 \%$ & $32 \%$ & $32 \%$ & $32 \%$ & $32 \%$ \\
\hline${ }^{131} \mathrm{Xe}$ & $19 \%$ & $19 \%$ & $19 \%$ & $19 \%$ & $19 \%$ & ${ }^{131} \mathrm{Xe}$ & $27 \%$ & $27 \%$ & $27 \%$ & $26 \%$ & $26 \%$ \\
\hline${ }^{135} \mathrm{Xe}$ & $8 \%$ & $7 \%$ & $1 \%$ & $1 \%$ & - & ${ }^{135} \mathrm{Xe}$ & $31 \%$ & $27 \%$ & $3 \%$ & $3 \%$ & - \\
\hline
\end{tabular}

\subsection{IMPACT OF CROSS SECTION LIBRARY ON ISOTOPIC PREDICTIONS}

Currently, 56-group libraries are recommended for the majority of Polaris calculations because their runtimes are faster than those in the 252-group library, and they have minimal impact on lattice eigenvalues for a wide range of internally investigated LWR configurations. Table 19 shows the percent change in the isotope composition when the more resolved 252-group cross section library is used instead of the 56-group library for $80 \mathrm{GWd} / \mathrm{MTU} 8 \mathrm{wt} \%$ fuel. Isotopes are screened to be above 0.5 parts per billion ( $\mathrm{ppb}$ ) of the initial uranium mass, or $500 \mu \mathrm{g}$ per metric ton of uranium. Only time 0 is used to compare masses, because most isotopes maintained their difference, regardless of decay time. A column listing the percent change introduced from increasing enrichment and burnup from $60 \mathrm{GWd} / \mathrm{MTU} 5 \mathrm{wt} \%$ to $80 \mathrm{GWd} / \mathrm{MTU} 8 \mathrm{wt} \%$ is included for comparison to demonstrate where the 56-group approximation may affect the takeaways in the isotope section. In both columns, percent change is computed as

$$
\frac{M_{i}}{M_{i, r e f}}-1
$$

The change in most isotopes from the cross section approximation is only a fraction of the change introduced when increasing burnup and enrichment from $60 \mathrm{GWd} / \mathrm{MTU} 5 \mathrm{wt} \%$ to $80 \mathrm{GWd} / \mathrm{MTU} 8 \mathrm{wt} \%$ fuel. For isotopes such as ${ }^{243} \mathrm{Am},{ }^{243} \mathrm{Pu},{ }^{244 \mathrm{~m}} \mathrm{Am},{ }^{244} \mathrm{Am},{ }^{242} \mathrm{Pu},{ }^{240} \mathrm{Pu},{ }^{131 \mathrm{~m}} \mathrm{Xe}$, and ${ }^{156} \mathrm{Eu}$, the change introduced by cross section library approximation is sizable compared with the change introduced by 
increasing burnup and enrichment. For the actinides, the change seems to be associated with the coarser handling of the ${ }^{238} \mathrm{U}$ resonance capture. All of these isotopes appear on the release term list, but they are each a small component of the total term. ${ }^{242} \mathrm{Pu}$ and ${ }^{240} \mathrm{Pu}$ appear in the list of isotopes that influence both shielding and criticality. In the case of shielding, they contribute little to the overall activity of the spent nuclear fuel in the timescales studied in this work, so the impact on shielding is likely small. This is also seen in the analysis presented in NUREG CR-5700 [9], in which the isotopes contribute negligible amounts at 5 years of cooling, but can be substantial source components at 100 years of cooling. Thus, the 56-group approximation used in work described in this section likely only impacts the ${ }^{242} \mathrm{Pu}$ and ${ }^{244} \mathrm{Pu}$ values for criticality, as well as the quantities of some release nuclides. The $5-10 \%$ differences in the isotopics predicted by the 56-group library compared with the 252-group are larger than expected, although it is understood that the main use case for Polaris with the 56-group library is to generate fewgroup nodal data, not isotopics. This 56-group library bias does not invalidate any conclusions made in this scoping study because the important burnup or enrichment differences were typically much larger. Future Polaris development work will consider these isotopic biases in multigroup library optimization to achieve a maximum of $\sim 5 \%$ bias in a relevant nuclide at $80 \mathrm{GWd} / \mathrm{MTU}$ for the 56-group library compared to the 252-group library. 
Table 19. Change in isotopics due to cross section library 252- vs 56-group

\begin{tabular}{|c|c|c|c|c|c|c|}
\hline 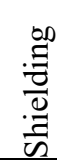 & 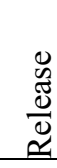 & 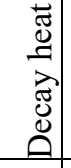 & : & Isotope & $\begin{array}{l}\text { Percent change in isotope } \\
\text { mass } 252 \text { - vs } 56 \text {-group }\end{array}$ & $\begin{array}{c}80 \mathrm{GWd} / \mathrm{MTU} 8 \mathrm{wt} \% \text { enriched vs } \\
60 \mathrm{GWd} / \mathrm{MTU} 5 \mathrm{wt} \% \\
\text { (for comparison) }\end{array}$ \\
\hline & $\checkmark$ & $\checkmark$ & & $\operatorname{cs} 136$ & $10.31 \%$ & $47.00 \%$ \\
\hline & $\checkmark$ & & & eu155 & $10.16 \%$ & $28.91 \%$ \\
\hline & & & & gd155 & $9.03 \%$ & $106.25 \%$ \\
\hline & $\checkmark$ & & & sb124 & $8.11 \%$ & $15.42 \%$ \\
\hline & $\checkmark$ & & & $\operatorname{am} 243$ & $-6.99 \%$ & $11.46 \%$ \\
\hline & $\checkmark$ & & & pu243 & $-5.30 \%$ & $-7.89 \%$ \\
\hline$\checkmark$ & $\checkmark$ & & $\checkmark$ & pu240 & $-4.85 \%$ & $8.02 \%$ \\
\hline$\checkmark$ & $\checkmark$ & & & am241 & $4.72 \%$ & $55.56 \%$ \\
\hline & & & & u234 & $4.32 \%$ & $62.38 \%$ \\
\hline & $\checkmark$ & & & sb125 & $4.25 \%$ & $9.30 \%$ \\
\hline & $\checkmark$ & & & te $125 \mathrm{~m}$ & $4.23 \%$ & $10.97 \%$ \\
\hline$\checkmark$ & $\checkmark$ & $\checkmark$ & & $\mathrm{cm} 244$ & $-4.04 \%$ & $21.49 \%$ \\
\hline$\checkmark$ & $\checkmark$ & & & pu242 & $4.04 \%$ & $5.55 \%$ \\
\hline & $\checkmark$ & & & $\operatorname{am} 244 m$ & $-3.45 \%$ & $-2.68 \%$ \\
\hline & $\checkmark$ & & & $\operatorname{am} 244$ & $-3.42 \%$ & $-2.64 \%$ \\
\hline & $\checkmark$ & & & eu153 & $3.38 \%$ & $24.17 \%$ \\
\hline$\checkmark$ & $\checkmark$ & $\checkmark$ & & pu238 & $3.27 \%$ & $67.38 \%$ \\
\hline & $\checkmark$ & & & pd112 & $3.03 \%$ & $-9.11 \%$ \\
\hline & $\checkmark$ & $\checkmark$ & & np238 & $2.85 \%$ & $28.61 \%$ \\
\hline & $\checkmark$ & & & xe131 & $2.60 \%$ & $26.68 \%$ \\
\hline & $\checkmark$ & & & sm147 & $2.44 \%$ & $52.91 \%$ \\
\hline & $\checkmark$ & & & rh103 & $-2.33 \%$ & $22.17 \%$ \\
\hline & $\checkmark$ & & & sm151 & $2.30 \%$ & $44.07 \%$ \\
\hline & $\checkmark$ & & & $\mathrm{rb} 86$ & $2.21 \%$ & $33.27 \%$ \\
\hline & $\checkmark$ & & & pu241 & $1.91 \%$ & $19.61 \%$ \\
\hline & $\checkmark$ & & & te $127 \mathrm{~m}$ & $1.82 \%$ & $10.24 \%$ \\
\hline & $\checkmark$ & & & xe131m & $1.81 \%$ & $-0.49 \%$ \\
\hline & $\checkmark$ & & & sm149 & $1.68 \%$ & $44.76 \%$ \\
\hline & $\checkmark$ & & & pd111 & $1.52 \%$ & $-10.10 \%$ \\
\hline & $\checkmark$ & & & $\operatorname{sm} 152$ & $-1.41 \%$ & $17.40 \%$ \\
\hline$\checkmark$ & $\checkmark$ & & $\checkmark$ & pu239 & $1.35 \%$ & $20.53 \%$ \\
\hline & $\checkmark$ & & & np237 & $-1.34 \%$ & $54.07 \%$ \\
\hline & $\checkmark$ & & & te 127 & $1.29 \%$ & $-4.37 \%$ \\
\hline & $\checkmark$ & $\checkmark$ & & eu156 & $-1.26 \%$ & $2.27 \%$ \\
\hline & $\checkmark$ & & & sb127 & $1.20 \%$ & $-5.85 \%$ \\
\hline & $\checkmark$ & & & pr142 & $1.13 \%$ & $10.41 \%$ \\
\hline & $\checkmark$ & & & np240 & $-1.12 \%$ & $-24.22 \%$ \\
\hline & $\checkmark$ & & & $\mathrm{am} 242$ & $1.05 \%$ & $21.15 \%$ \\
\hline & $\checkmark$ & & & xe135 & $1.04 \%$ & $30.94 \%$ \\
\hline
\end{tabular}




\section{CONCLUSIONS}

Calculations were performed using the SCALE Polaris, TSUNAMI, and ORIGEN computer codes to evaluate the effects of EE and HBU on depletion characteristics of a representative commercial PWR fuel assembly (Westinghouse $17 \times 17$ with 104 IFBA rods). The investigation focused on differences between depletion to well-understood conditions ( $5 \mathrm{wt} \% 235 \mathrm{U}$ depleted to $60 \mathrm{GWd} / \mathrm{MTU}$ ) and depletion with enrichment up to $8 \mathrm{wt} \%$ and burnup up to $80 \mathrm{GWd} / \mathrm{MTU}$.

Key quantities of interest include lattice physics parameters, isotopic inventory at various decay times, neutronic similarity of fuel assemblies in SFP storage, and relative uncertainty in $k_{\text {inf }}$ due to cross section uncertainty, including the effect of cross section uncertainty on isotopic content. Limited comparisons between predictions using SCALE 56-group ENDF/B-VII.1 cross sections and SCALE 252-group ENDF/B-VII.1 cross sections are also presented. Conclusions from this evaluation are as follows.

1. No unexpected or anomalous trends were found that would call into question the accuracy of the Polaris code using SCALE 56-group ENDF/B-VII.1 cross sections for depletion, lattice physics, and isotopic content calculations of the analyzed PWR fuel with enrichments up to $8 \mathrm{wt} \%$ and burnup up to $80 \mathrm{GWd} / \mathrm{MTU}$.

2. Increased enrichment and higher burnup are positively correlated due to the requirements of commercial PWR fuel management (fuel economics and reactor physics). This correlation tends to result in offsetting lattice physics effects when combined with single-assembly results to estimate core average characteristics.

3. Lattice physics results from the Polaris model depletion of a Westinghouse $17 \times 17$ fuel assembly with 104 IFBA rods overall showed no unusual, unexpected, or adverse code performance trends.

a. Calculated fuel $\mathrm{k}_{\text {inf, }}$ peaking factors, and reactivity coefficients are smooth and continuous as a function of enrichment and burnup.

b. Lattice physics trends were predictable from first principles (e.g., spectral hardening resulting from increased ${ }^{235} \mathrm{U}$ enrichment).

c. A first-order approximation shows that core average burnup is expected to increase $11 \mathrm{GWd} / \mathrm{MTU}$ for each $1.5 \mathrm{wt} \%$ increase in fuel enrichment above $5 \mathrm{wt} \%$. This approximation can be used to extend the results of single-assembly lattice physics calculations to expected core average behavior.

d. Core average temperature coefficients (MTC, DTC) and kinetics parameters ( $\beta$-eff and delayed neutron decay constant) are not expected to change substantially due to the offsetting effects of increased enrichment and increased burnup.

e. The soluble boron requirement increases strongly with increasing enrichment.

f. Assembly pin peaking increases modestly with increasing enrichment.

g. Power variation that occurs radially across fuel pellets (the "rim effect") at the same fuel pin burnup declines with increasing enrichment.

4. The TSUNAMI-IP similarity index ck is $>0.98$ for assemblies of different enrichment / burnup combinations ( $5 \mathrm{wt} \% 60 \mathrm{GWd} / \mathrm{MTU}, 8 \mathrm{wt} \% 84 \mathrm{GWd} / \mathrm{MTU}$, and $8 \mathrm{wt} \% 94 \mathrm{GWd} / \mathrm{MTU}$ ) in a 
representative SFP rack cell. This suggests that SFP burnup credit criticality code validation should not be strongly impacted by HALEU/HBU. Uncertainty in $\mathrm{k}_{\text {inf }}$ due to cross section uncertainty is similar for the three rack cell cases.

5. The effect of cross section uncertainty on perturbed cross section depletion $\mathrm{k}_{\text {inf }}$ increases slightly from $60 \mathrm{GWd} / \mathrm{MTU}$ to $80 \mathrm{GWd} / \mathrm{MTU}(\sim 0.1 \% \Delta \mathrm{k} / \mathrm{k})$. The lists of the top 25 nuclides most important to criticality for $5 \mathrm{wt} \%$ fuel at 60 and $80 \mathrm{GWd} / \mathrm{MTU}$ differ by only one nuclide.

6. Increasing enrichment from 5 to $8 \mathrm{wt} \%$ at $60 \mathrm{GWd} / \mathrm{MTU}$ leads to minor changes in decay heat. At time $=0$, decay heat increased by $3 \%$ and then decreased to $-10 \%$ at 500 days for the $8 \mathrm{wt} \%$ case compared with the reference $5 \mathrm{wt} \%$ case.

7. Increasing burnup from 60 to $80 \mathrm{GWd} / \mathrm{MTU}$ for $8 \mathrm{wt} \%$ leads to a negligible change at time $=0$ and a growing change from 5 days $(5 \%)$ to 500 days $(30 \%)$ for the $80 \mathrm{GWd} / \mathrm{MTU}$ case compared with the reference $60 \mathrm{GWd} / \mathrm{MTU}$. At 500 days, the $80 \mathrm{GWd} / \mathrm{MTU}$ fuel has $\sim 14 \mathrm{~kW} / \mathrm{MTU}$ decay heat compared with $\sim 11 \mathrm{~kW} / \mathrm{MTU}$ for the base case.

8. Effects of increases in burnup and enrichment on decay heat are in opposite directions, so the combined effect is a $15 \%$ increase at 500 days for increased enrichment and burnup compared with a $30 \%$ increase for only burnup.

9. Activity shows similar trends to decay heat, but with less magnitude.

10. Isotopic results from the Polaris model depletion of a Westinghouse $17 \times 17$ fuel assembly with 104 IFBA rods overall showed no unusual, unexpected, or adverse code performance trends.

a. No single isotope influenced decay heat by more than $10 \%$ in any case analyzed.

b. No single isotope changed activity by more than $5 \%$ in any case analyzed.

c. Curium-244 is the main isotope that changes the spontaneous neutron emission source substantially for the timescales in question.

d. Of the criticality-related isotopes evaluated, only ${ }^{243} \mathrm{Am}$ and ${ }^{155} \mathrm{Gd}$ changed in composition by over a factor of 2 for the cases analyzed.

e. When changing from the 252- to the 56-group library, no isotope changed in mass by more than $11 \%$ for the $80 \mathrm{GWd} / \mathrm{MTU}, 8 \mathrm{wt} \%$ case.

\section{ACKNOWLEDGMENTS}

Support for this work was provided by the US Nuclear Regulatory Commission Offices of Nuclear Regulatory Research, Nuclear Reactor Regulation, and Nuclear Material Safety and Safeguards. The authors would also like to thank many ORNL staff members for feedback on the contents and presentation in this report. 


\section{REFERENCES}

1. M. Diaz, 2019, DSFM Regulatory Conference, "Advanced Fuels Update on the Front End of the Fuel Cycle," https://www.nrc.gov/docs/ML1925/ML19255F598.pdf.

2. F. Pimental et al., 2019, "The Economic Benefits and Challenges with Utilizing Increased Enrichment and Fuel Burnup for Light-Water Reactors," Nuclear Energy Institute.

3. C. E. Sanders and J. C. Wagner, 2001, Study of the Effect of Integral Burnable Absorbers for PWR Burnup Credit, NUREG/CR-6760.

4. W. A. Wieselquist, R. A. Lefebvre, and M. A. Jessee, Eds., SCALE Code System, ORNL/TM2005/39, Version 6.2.4, Oak Ridge National Laboratory, Oak Ridge, TN (2020).

5. Nuclear Engineering and fuel Dominion Resources Services, Inc. 2016, Safety Evaluation Report Criticality Safety Evaluation of the North Anna New Fuel Storage Area and Spent Fuel Pool Allowing 5 wt\% U-235 Enriched Fuel” ML17129A452.

6. B. T. Rearden et al., 2010. "Sensitivity and Uncertainty Analysis Capabilities and Data in SCALE," Nuclear Technology 174(2), pp. 236-288.

7. Electric Power Research Institute 2017, Benchmarks for Qualifying Fuel Reactivity Depletion Uncertainty-Revision 1, ADAMS ML18088B397.

8. US Nuclear Regulatory Commission 2000. Regulatory Guide 1.183: Alternative Radiological Source Terms for Evaluating Design Basis Accidents at Nuclear Power Reactors.

9. Oak Ridge National Laboratory, 2000, Nuclide Importance to Criticality Safety, Decay Heating, and Source Terms Related to Transport and Interim Storage of High-Burnup LWR Fuel, NUREG/CR6700 . 


\section{APPENDIX A. ACTIVITY DATA TABLES}

This appendix lists the activities for each isotope of selected spent nuclear fuel lattices as a fraction of total activity in the tables below. The total activity listed for all isotopes is also provided to allow for conversion to activity. The isotopes are ordered by RMS of contribution to total activity. Checkmarks indicate whether the isotopes were considered important to shielding, release term, decay heat, or activity in this study.

Activity: an isotope ranked in the top 10 activities for any time point, so the number of check marks is greater than 10 .

Decay heat: an isotope ranked in the top 15 RMS changes in decay heat evaluated in Section 4.

Shielding: an isotope relevant to shielding applications 5 years after discharge as designated in NUREG/CR-6700. Note that at short time frames, many more isotopes are likely applicable to shielding.

Release: an isotope which is an element required to be evaluated for alternate release source terms per Regulatory Guide 1.183 and for which the RMS taken across non-zero timepoints is greater than $0.1 \%$.

Table A.1. Fractional contributions of istopes to total activity of $60 \mathrm{GWd} / \mathrm{MTU} 5 \mathrm{wt} \%$ case

\begin{tabular}{|c|c|c|c|c|c|c|c|c|c|}
\hline & & & & & \\
\hline & & & & & $\mathbf{0} \mathbf{s}$ & $30 \mathrm{~m}$ & $5 \mathrm{~d}$ & $25 \mathrm{~d}$ & $500 \mathrm{~d}$ \\
\hline \multicolumn{5}{|c|}{ Total calculated (MCi/MTU) } & 240.30 & 117.60 & 33.11 & 15.91 & 2.83 \\
\hline \multicolumn{5}{|c|}{ Total listed (MCi/MTU) } & 127.30 & 104.07 & 32.18 & 15.76 & 2.82 \\
\hline & & & & & \multicolumn{5}{|c|}{ Fraction of activity from isotope } \\
\hline 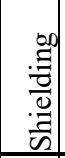 & 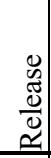 & 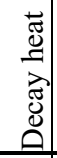 & 预 & $\begin{array}{l}\mathscr{0} \\
\stackrel{0}{0} \\
\stackrel{0}{0} \\
\mathscr{a}\end{array}$ & $0 \mathrm{~s}$ & $30 \mathrm{~m}$ & $5 \mathrm{~d}$ & $25 \mathrm{~d}$ & $500 \mathrm{~d}$ \\
\hline & $\checkmark$ & $\checkmark$ & $\checkmark$ & ${ }^{239} \mathrm{~Np}$ & $9.8 \mathrm{E}-2$ & 2.0E-1 & $1.6 \mathrm{E}-1$ & $9.6 \mathrm{E}-4$ & $1.8 \mathrm{E}-5$ \\
\hline \multirow[t]{8}{*}{$\checkmark$} & $\checkmark$ & $\checkmark$ & $\checkmark$ & ${ }^{144} \mathrm{Pr}$ & $6.0 \mathrm{E}-3$ & $1.2 \mathrm{E}-2$ & $4.3 \mathrm{E}-2$ & $8.5 \mathrm{E}-2$ & $1.5 \mathrm{E}-1$ \\
\hline & $\checkmark$ & & $\checkmark$ & ${ }^{144} \mathrm{Ce}$ & $5.9 \mathrm{E}-3$ & $1.2 \mathrm{E}-2$ & $4.3 \mathrm{E}-2$ & $8.5 \mathrm{E}-2$ & $1.5 \mathrm{E}-1$ \\
\hline & $\checkmark$ & & $\checkmark$ & ${ }^{106} \mathrm{Ru}$ & $3.5 \mathrm{E}-3$ & 7.1E-3 & $2.5 \mathrm{E}-2$ & $5.0 \mathrm{E}-2$ & $1.2 \mathrm{E}-1$ \\
\hline & $\checkmark$ & & $\checkmark$ & ${ }^{106} \mathrm{Ru}$ & $3.5 \mathrm{E}-3$ & 7.1E-3 & $2.5 \mathrm{E}-2$ & $5.0 \mathrm{E}-2$ & $1.2 \mathrm{E}-1$ \\
\hline & $\checkmark$ & $\checkmark$ & $\checkmark$ & ${ }^{95} \mathrm{Nb}$ & 7.0E-3 & $1.4 \mathrm{E}-2$ & $5.0 \mathrm{E}-2$ & $1.0 \mathrm{E}-1$ & $5.8 \mathrm{E}-3$ \\
\hline & $\checkmark$ & $\checkmark$ & $\checkmark$ & ${ }^{95} \mathrm{Zr}$ & $6.9 \mathrm{E}-3$ & $1.4 \mathrm{E}-2$ & $4.8 \mathrm{E}-2$ & $8.0 \mathrm{E}-2$ & $2.6 \mathrm{E}-3$ \\
\hline & $\checkmark$ & $\checkmark$ & $\checkmark$ & ${ }^{103} \mathrm{Ru}$ & $7.8 \mathrm{E}-3$ & $1.6 \mathrm{E}-2$ & $5.2 \mathrm{E}-2$ & 7.6E-2 & $9.7 \mathrm{E}-5$ \\
\hline & $\checkmark$ & & $\checkmark$ & ${ }^{103 \mathrm{~m} R h}$ & $7.7 \mathrm{E}-3$ & $1.6 \mathrm{E}-2$ & $5.1 \mathrm{E}-2$ & $7.5 \mathrm{E}-2$ & $9.6 \mathrm{E}-5$ \\
\hline \multirow[t]{5}{*}{$\checkmark$} & $\checkmark$ & $\checkmark$ & $\checkmark$ & ${ }^{134} \mathrm{Cs}$ & $1.5 \mathrm{E}-3$ & $3.1 \mathrm{E}-3$ & $1.1 \mathrm{E}-2$ & 2.2E-2 & $8.0 \mathrm{E}-2$ \\
\hline & $\checkmark$ & & $\checkmark$ & ${ }^{141} \mathrm{Ce}$ & $7.1 \mathrm{E}-3$ & $1.4 \mathrm{E}-2$ & $4.6 \mathrm{E}-2$ & $6.3 \mathrm{E}-2$ & $1.4 \mathrm{E}-5$ \\
\hline & $\checkmark$ & & $\checkmark$ & ${ }^{241} \mathrm{Pu}$ & $9.6 \mathrm{E}-4$ & $2.0 \mathrm{E}-3$ & 7.0E-3 & $1.4 \mathrm{E}-2$ & $7.6 \mathrm{E}-2$ \\
\hline & $\checkmark$ & $\checkmark$ & $\checkmark$ & ${ }^{137} \mathrm{Cs}$ & $7.8 \mathrm{E}-4$ & $1.6 \mathrm{E}-3$ & $5.7 \mathrm{E}-3$ & $1.2 \mathrm{E}-2$ & $6.4 \mathrm{E}-2$ \\
\hline & $\checkmark$ & $\checkmark$ & $\checkmark$ & ${ }^{91} \mathrm{Y}$ & $4.6 \mathrm{E}-3$ & $9.5 \mathrm{E}-3$ & $3.2 \mathrm{E}-2$ & $5.3 \mathrm{E}-2$ & $1.1 \mathrm{E}-3$ \\
\hline \multirow[t]{6}{*}{$\checkmark$} & $\checkmark$ & $\checkmark$ & $\checkmark$ & ${ }^{137 \mathrm{~m}} \mathrm{Ba}$ & 7.4E-4 & $1.5 \mathrm{E}-3$ & $5.4 \mathrm{E}-3$ & $1.1 \mathrm{E}-2$ & $6.1 \mathrm{E}-2$ \\
\hline & $\checkmark$ & $\checkmark$ & $\checkmark$ & ${ }^{140} \mathrm{La}$ & 7.9E-3 & $1.6 \mathrm{E}-2$ & 4.7E-2 & $3.4 \mathrm{E}-2$ & $1.2 \mathrm{E}-12$ \\
\hline & $\checkmark$ & & $\checkmark$ & ${ }^{147} \mathrm{Pm}$ & $8.8 \mathrm{E}-4$ & $1.8 \mathrm{E}-3$ & $6.4 \mathrm{E}-3$ & $1.3 \mathrm{E}-2$ & $5.4 \mathrm{E}-2$ \\
\hline & $\checkmark$ & & $\checkmark$ & ${ }^{140} \mathrm{Ba}$ & $7.6 \mathrm{E}-3$ & $1.5 \mathrm{E}-2$ & 4.2E-2 & $2.9 \mathrm{E}-2$ & $1.0 \mathrm{E}-12$ \\
\hline & $\checkmark$ & & & ${ }^{143} \mathrm{Pr}$ & $6.5 \mathrm{E}-3$ & $1.3 \mathrm{E}-2$ & 4.0E-2 & $3.0 \mathrm{E}-2$ & $5.0 \mathrm{E}-12$ \\
\hline & $\checkmark$ & $\checkmark$ & & ${ }^{89} \mathrm{Sr}$ & $3.5 \mathrm{E}-3$ & 7.1E-3 & $2.4 \mathrm{E}-2$ & $3.7 \mathrm{E}-2$ & $3.1 \mathrm{E}-4$ \\
\hline
\end{tabular}




\begin{tabular}{|c|c|c|c|c|c|c|c|c|c|}
\hline \multirow[b]{2}{*}{ 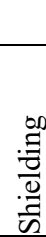 } & \multirow[b]{2}{*}{$\begin{array}{l}\mathscr{U} \\
\tilde{\Xi} \\
\mathscr{\Phi} \\
\underline{\simeq}\end{array}$} & \multirow[b]{2}{*}{ 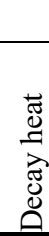 } & \multirow[b]{2}{*}{ 总 } & \multirow[b]{2}{*}{$\begin{array}{l}0 \\
0 \\
0 \\
0 \\
0\end{array}$} & \multicolumn{5}{|c|}{ Fraction of activity from isotope } \\
\hline & & & & & $0 \mathrm{~s}$ & $30 \mathrm{~m}$ & $5 \mathrm{~d}$ & $25 \mathrm{~d}$ & $500 \mathrm{~d}$ \\
\hline \multirow[t]{41}{*}{$\sqrt{ }$} & $\checkmark$ & $\checkmark$ & $\checkmark$ & ${ }^{90} \mathrm{Y}$ & $5.5 \mathrm{E}-4$ & $1.1 \mathrm{E}-3$ & $3.9 \mathrm{E}-3$ & $8.0 \mathrm{E}-3$ & $4.3 \mathrm{E}-2$ \\
\hline & $\checkmark$ & $\checkmark$ & & ${ }^{90} \mathrm{Sr}$ & $5.3 \mathrm{E}-4$ & $1.1 \mathrm{E}-3$ & $3.8 \mathrm{E}-3$ & $8.0 \mathrm{E}-3$ & $4.3 \mathrm{E}-2$ \\
\hline & $\checkmark$ & & $\checkmark$ & ${ }^{133} \mathrm{Xe}$ & $8.7 \mathrm{E}-3$ & $1.8 \mathrm{E}-2$ & $4.0 \mathrm{E}-2$ & $6.0 \mathrm{E}-3$ & $0.0 \mathrm{E}+0$ \\
\hline & $\checkmark$ & & & ${ }^{131} \mathrm{I}$ & $4.6 \mathrm{E}-3$ & $9.3 \mathrm{E}-3$ & $2.2 \mathrm{E}-2$ & $8.3 \mathrm{E}-3$ & $7.1 \mathrm{E}-20$ \\
\hline & $\checkmark$ & & $\checkmark$ & ${ }^{99} \mathrm{Mo}$ & $8.3 \mathrm{E}-3$ & $1.7 \mathrm{E}-2$ & $1.7 \mathrm{E}-2$ & $2.3 \mathrm{E}-4$ & $0.0 \mathrm{E}+0$ \\
\hline & $\checkmark$ & & & ${ }^{99} \mathrm{~m} T \mathrm{c}$ & $7.3 \mathrm{E}-3$ & $1.5 \mathrm{E}-2$ & $1.6 \mathrm{E}-2$ & $2.2 \mathrm{E}-4$ & $0.0 \mathrm{E}+0$ \\
\hline & $\checkmark$ & & & ${ }^{132} \mathrm{I}$ & $6.6 \mathrm{E}-3$ & $1.3 \mathrm{E}-2$ & $1.6 \mathrm{E}-2$ & $4.5 \mathrm{E}-4$ & $0.0 \mathrm{E}+0$ \\
\hline & $\checkmark$ & & & ${ }^{132} \mathrm{Te}$ & $6.4 \mathrm{E}-3$ & $1.3 \mathrm{E}-2$ & $1.6 \mathrm{E}-2$ & $4.3 \mathrm{E}-4$ & $0.0 \mathrm{E}+0$ \\
\hline & $\checkmark$ & & & ${ }^{147} \mathrm{Nd}$ & $2.9 \mathrm{E}-3$ & $5.9 \mathrm{E}-3$ & $1.5 \mathrm{E}-2$ & $8.9 \mathrm{E}-3$ & $4.8 \mathrm{E}-15$ \\
\hline & $\checkmark$ & & $\checkmark$ & ${ }^{133} \mathrm{I}$ & $9.1 \mathrm{E}-3$ & $1.8 \mathrm{E}-2$ & $1.2 \mathrm{E}-3$ & $2.9 \mathrm{E}-10$ & $0.0 \mathrm{E}+0$ \\
\hline & $\checkmark$ & & $\checkmark$ & ${ }^{134} \mathrm{I}$ & $1.0 \mathrm{E}-2$ & $1.8 \mathrm{E}-2$ & $0.0 \mathrm{E}+0$ & $0.0 \mathrm{E}+0$ & $0.0 \mathrm{E}+0$ \\
\hline & $\checkmark$ & & $\checkmark$ & ${ }^{135} \mathrm{I}$ & $8.7 \mathrm{E}-3$ & $1.7 \mathrm{E}-2$ & $2.0 \mathrm{E}-7$ & $0.0 \mathrm{E}+0$ & $0.0 \mathrm{E}+0$ \\
\hline & $\checkmark$ & & & ${ }^{97} \mathrm{Nb}$ & $7.4 \mathrm{E}-3$ & $1.5 \mathrm{E}-2$ & $3.7 \mathrm{E}-4$ & $2.0 \mathrm{E}-12$ & $0.0 \mathrm{E}+0$ \\
\hline & $\checkmark$ & & & ${ }^{97} \mathrm{Zr}$ & $7.3 \mathrm{E}-3$ & $1.5 \mathrm{E}-2$ & $3.7 \mathrm{E}-4$ & $1.8 \mathrm{E}-12$ & $0.0 \mathrm{E}+0$ \\
\hline & $\checkmark$ & $\checkmark$ & & ${ }^{156} \mathrm{Eu}$ & $1.8 \mathrm{E}-3$ & $3.8 \mathrm{E}-3$ & $1.1 \mathrm{E}-2$ & $8.9 \mathrm{E}-3$ & $1.9 \mathrm{E}-11$ \\
\hline & $\checkmark$ & & & ${ }^{141} \mathrm{La}$ & $7.1 \mathrm{E}-3$ & $1.4 \mathrm{E}-2$ & $3.4 \mathrm{E}-11$ & $0.0 \mathrm{E}+0$ & $0.0 \mathrm{E}+0$ \\
\hline & $\checkmark$ & & & ${ }^{139} \mathrm{Ba}$ & $7.9 \mathrm{E}-3$ & $1.4 \mathrm{E}-2$ & $0.0 \mathrm{E}+0$ & $0.0 \mathrm{E}+0$ & $0.0 \mathrm{E}+0$ \\
\hline & $\checkmark$ & & & ${ }^{97 \mathrm{~m}} \mathrm{Nb}$ & $7.0 \mathrm{E}-3$ & $1.4 \mathrm{E}-2$ & $3.5 \mathrm{E}-4$ & $1.7 \mathrm{E}-12$ & $0.0 \mathrm{E}+0$ \\
\hline & $\checkmark$ & & & ${ }^{143} \mathrm{Ce}$ & $6.5 \mathrm{E}-3$ & $1.3 \mathrm{E}-2$ & $3.8 \mathrm{E}-3$ & $3.4 \mathrm{E}-7$ & $0.0 \mathrm{E}+0$ \\
\hline & $\checkmark$ & & & ${ }^{138} \mathrm{Cs}$ & $8.3 \mathrm{E}-3$ & $1.3 \mathrm{E}-2$ & $0.0 \mathrm{E}+0$ & $0.0 \mathrm{E}+0$ & $0.0 \mathrm{E}+0$ \\
\hline & $\checkmark$ & & & ${ }^{142} \mathrm{La}$ & $6.8 \mathrm{E}-3$ & $1.2 \mathrm{E}-2$ & $0.0 \mathrm{E}+0$ & $0.0 \mathrm{E}+0$ & $0.0 \mathrm{E}+0$ \\
\hline & $\checkmark$ & & & ${ }^{93} \mathrm{Y}$ & $5.9 \mathrm{E}-3$ & $1.2 \mathrm{E}-2$ & $1.2 \mathrm{E}-5$ & $1.6 \mathrm{E}-19$ & $0.0 \mathrm{E}+0$ \\
\hline & $\checkmark$ & & & ${ }^{105} \mathrm{Rh}$ & $5.3 \mathrm{E}-3$ & $1.1 \mathrm{E}-2$ & $4.2 \mathrm{E}-3$ & $7.2 \mathrm{E}-7$ & $0.0 \mathrm{E}+0$ \\
\hline & $\checkmark$ & & & ${ }^{105} \mathrm{Ru}$ & $5.8 \mathrm{E}-3$ & $1.1 \mathrm{E}-2$ & $3.2 \mathrm{E}-10$ & $0.0 \mathrm{E}+0$ & $0.0 \mathrm{E}+0$ \\
\hline & $\checkmark$ & & & ${ }^{92} \mathrm{Y}$ & $5.0 \mathrm{E}-3$ & $1.0 \mathrm{E}-2$ & $9.7 \mathrm{E}-12$ & $0.0 \mathrm{E}+0$ & $0.0 \mathrm{E}+0$ \\
\hline & $\checkmark$ & & & ${ }^{134} \mathrm{Te}$ & $7.7 \mathrm{E}-3$ & $9.6 \mathrm{E}-3$ & $0.0 \mathrm{E}+0$ & $0.0 \mathrm{E}+0$ & $0.0 \mathrm{E}+0$ \\
\hline & $\checkmark$ & & & ${ }^{{ }^{101} \mathrm{Tc}}$ & $7.8 \mathrm{E}-3$ & $9.3 \mathrm{E}-3$ & $0.0 \mathrm{E}+0$ & $0.0 \mathrm{E}+0$ & $0.0 \mathrm{E}+0$ \\
\hline & $\checkmark$ & & & ${ }^{92} \mathrm{Sr}$ & $5.0 \mathrm{E}-3$ & $9.0 \mathrm{E}-3$ & $1.7 \mathrm{E}-15$ & $0.0 \mathrm{E}+0$ & $0.0 \mathrm{E}+0$ \\
\hline & $\checkmark$ & & & ${ }^{91} \mathrm{Sr}$ & $4.5 \mathrm{E}-3$ & $8.9 \mathrm{E}-3$ & $5.8 \mathrm{E}-6$ & $1.2 \mathrm{E}-20$ & $0.0 \mathrm{E}+0$ \\
\hline & $\checkmark$ & $\checkmark$ & & ${ }^{242} \mathrm{Cm}$ & $4.7 \mathrm{E}-4$ & $9.7 \mathrm{E}-4$ & $3.4 \mathrm{E}-3$ & $6.5 \mathrm{E}-3$ & $4.8 \mathrm{E}-3$ \\
\hline & $\checkmark$ & & & ${ }^{145} \mathrm{Pr}$ & $4.5 \mathrm{E}-3$ & $8.7 \mathrm{E}-3$ & $3.0 \mathrm{E}-8$ & $0.0 \mathrm{E}+0$ & $0.0 \mathrm{E}+0$ \\
\hline & $\checkmark$ & $\checkmark$ & & ${ }^{238} \mathrm{~Np}$ & $3.4 \mathrm{E}-3$ & $6.9 \mathrm{E}-3$ & $4.8 \mathrm{E}-3$ & $1.4 \mathrm{E}-5$ & $2.4 \mathrm{E}-8$ \\
\hline & $\checkmark$ & & & ${ }^{149} \mathrm{Pm}$ & $2.5 \mathrm{E}-3$ & $5.2 \mathrm{E}-3$ & $3.9 \mathrm{E}-3$ & $1.6 \mathrm{E}-5$ & $0.0 \mathrm{E}+0$ \\
\hline & $\checkmark$ & & & ${ }^{153} \mathrm{Sm}$ & $2.7 \mathrm{E}-3$ & $5.4 \mathrm{E}-3$ & $3.2 \mathrm{E}-3$ & $5.3 \mathrm{E}-6$ & $0.0 \mathrm{E}+0$ \\
\hline & $\checkmark$ & & & ${ }^{133 \mathrm{~m} T e}$ & $4.4 \mathrm{E}-3$ & $6.2 \mathrm{E}-3$ & $0.0 \mathrm{E}+0$ & $0.0 \mathrm{E}+0$ & $0.0 \mathrm{E}+0$ \\
\hline & $\checkmark$ & & & ${ }^{131} \mathrm{Te}$ & $3.9 \mathrm{E}-3$ & $6.1 \mathrm{E}-3$ & $1.4 \mathrm{E}-4$ & $1.3 \mathrm{E}-8$ & $0.0 \mathrm{E}+0$ \\
\hline & $\checkmark$ & & & ${ }^{243} \mathrm{Pu}$ & $3.1 \mathrm{E}-3$ & $6.0 \mathrm{E}-3$ & $1.2 \mathrm{E}-9$ & $1.9 \mathrm{E}-13$ & $1.1 \mathrm{E}-12$ \\
\hline & $\checkmark$ & & & ${ }^{135} \mathrm{Xe}$ & $2.6 \mathrm{E}-3$ & $5.8 \mathrm{E}-3$ & $2.0 \mathrm{E}-5$ & $6.6 \mathrm{E}-21$ & $0.0 \mathrm{E}+0$ \\
\hline & $\checkmark$ & & & ${ }^{91 \mathrm{~m} Y}$ & $2.7 \mathrm{E}-3$ & $5.4 \mathrm{E}-3$ & $3.7 \mathrm{E}-6$ & 7.7E-21 & $0.0 \mathrm{E}+0$ \\
\hline & $\checkmark$ & & & ${ }^{85} \mathrm{Kr}$ & $6.7 \mathrm{E}-5$ & $1.4 \mathrm{E}-4$ & $4.9 \mathrm{E}-4$ & $1.0 \mathrm{E}-3$ & $5.2 \mathrm{E}-3$ \\
\hline & $\checkmark$ & & & ${ }^{146} \mathrm{Pr}$ & $3.6 \mathrm{E}-3$ & $5.1 \mathrm{E}-3$ & $0.0 \mathrm{E}+0$ & $0.0 \mathrm{E}+0$ & $0.0 \mathrm{E}+0$ \\
\hline \multirow[t]{5}{*}{$\checkmark$} & $\checkmark$ & $\checkmark$ & & ${ }^{154} \mathrm{Eu}$ & $6.3 \mathrm{E}-5$ & $1.3 \mathrm{E}-4$ & $4.6 \mathrm{E}-4$ & $9.5 \mathrm{E}-4$ & $4.8 \mathrm{E}-3$ \\
\hline & $\checkmark$ & & & ${ }^{88} \mathrm{Rb}$ & $2.6 \mathrm{E}-3$ & $4.9 \mathrm{E}-3$ & $3.9 \mathrm{E}-15$ & $0.0 \mathrm{E}+0$ & $0.0 \mathrm{E}+0$ \\
\hline & $\checkmark$ & & & ${ }^{141} \mathrm{Ba}$ & $7.0 \mathrm{E}-3$ & $4.7 \mathrm{E}-3$ & $0.0 \mathrm{E}+0$ & $0.0 \mathrm{E}+0$ & $0.0 \mathrm{E}+0$ \\
\hline & $\checkmark$ & & & ${ }^{148} \mathrm{Pm}$ & $1.1 \mathrm{E}-3$ & $2.2 \mathrm{E}-3$ & $4.1 \mathrm{E}-3$ & $7.3 \mathrm{E}-4$ & $1.8 \mathrm{E}-7$ \\
\hline & $\checkmark$ & $\checkmark$ & & ${ }^{104} \mathrm{Tc}$ & $6.7 \mathrm{E}-3$ & $4.6 \mathrm{E}-3$ & $0.0 \mathrm{E}+0$ & $0.0 \mathrm{E}+0$ & $0.0 \mathrm{E}+0$ \\
\hline
\end{tabular}




\begin{tabular}{|c|c|c|c|c|c|c|c|c|c|}
\hline \multirow[b]{2}{*}{ 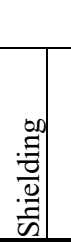 } & \multirow[b]{2}{*}{ 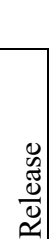 } & \multirow[b]{2}{*}{ 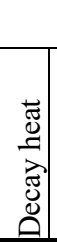 } & \multirow[b]{2}{*}{ 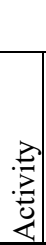 } & \multirow[b]{2}{*}{$\begin{array}{l}0 \\
0 \\
0 \\
0 \\
0\end{array}$} & \multicolumn{5}{|c|}{ Fraction of activity from isotope } \\
\hline & & & & & $0 \mathrm{~s}$ & $30 \mathrm{~m}$ & $5 \mathrm{~d}$ & $25 \mathrm{~d}$ & $500 \mathrm{~d}$ \\
\hline & $\checkmark$ & & & ${ }^{88} \mathrm{Kr}$ & $2.5 \mathrm{E}-3$ & $4.5 \mathrm{E}-3$ & $3.5 \mathrm{E}-15$ & $0.0 \mathrm{E}+0$ & $0.0 \mathrm{E}+0$ \\
\hline & $\checkmark$ & & & ${ }^{94} \mathrm{Y}$ & $6.3 \mathrm{E}-3$ & $4.5 \mathrm{E}-3$ & $0.0 \mathrm{E}+0$ & $0.0 \mathrm{E}+0$ & $0.0 \mathrm{E}+0$ \\
\hline \multirow[t]{4}{*}{$\checkmark$} & $\checkmark$ & $\checkmark$ & & ${ }^{244} \mathrm{Cm}$ & $5.2 \mathrm{E}-5$ & $1.1 \mathrm{E}-4$ & $3.8 \mathrm{E}-4$ & $7.8 \mathrm{E}-4$ & $4.2 \mathrm{E}-3$ \\
\hline & $\checkmark$ & & & ${ }^{109} \mathrm{Pd}$ & $2.1 \mathrm{E}-3$ & $4.2 \mathrm{E}-3$ & $3.5 \mathrm{E}-5$ & $2.1 \mathrm{E}-15$ & $0.0 \mathrm{E}+0$ \\
\hline & $\checkmark$ & & & ${ }^{125} \mathrm{Sb}$ & $6.5 \mathrm{E}-5$ & $1.3 \mathrm{E}-4$ & $4.7 \mathrm{E}-4$ & $9.7 \mathrm{E}-4$ & $3.9 \mathrm{E}-3$ \\
\hline & $\checkmark$ & & & ${ }^{101} \mathrm{Mo}$ & $7.8 \mathrm{E}-3$ & $3.9 \mathrm{E}-3$ & $0.0 \mathrm{E}+0$ & $0.0 \mathrm{E}+0$ & $0.0 \mathrm{E}+0$ \\
\hline \multirow[t]{35}{*}{$\checkmark$} & $\checkmark$ & $\checkmark$ & & ${ }^{238} \mathrm{Pu}$ & $3.9 \mathrm{E}-5$ & $8.0 \mathrm{E}-5$ & $2.9 \mathrm{E}-4$ & $6.0 \mathrm{E}-4$ & $3.5 \mathrm{E}-3$ \\
\hline & $\checkmark$ & & & ${ }^{138} \mathrm{Xe}$ & $7.5 \mathrm{E}-3$ & $3.5 \mathrm{E}-3$ & $0.0 \mathrm{E}+0$ & $0.0 \mathrm{E}+0$ & $0.0 \mathrm{E}+0$ \\
\hline & $\checkmark$ & & & ${ }^{107} \mathrm{Rh}$ & $3.4 \mathrm{E}-3$ & $3.3 \mathrm{E}-3$ & $0.0 \mathrm{E}+0$ & $0.0 \mathrm{E}+0$ & $0.0 \mathrm{E}+0$ \\
\hline & $\checkmark$ & & & ${ }^{105 \mathrm{~m} R h}$ & $1.7 \mathrm{E}-3$ & $3.2 \mathrm{E}-3$ & $9.1 \mathrm{E}-11$ & $0.0 \mathrm{E}+0$ & $0.0 \mathrm{E}+0$ \\
\hline & $\checkmark$ & & & ${ }^{135 \mathrm{~m} X e}$ & $2.0 \mathrm{E}-3$ & $3.2 \mathrm{E}-3$ & $3.5 \mathrm{E}-8$ & $0.0 \mathrm{E}+0$ & $0.0 \mathrm{E}+0$ \\
\hline & $\checkmark$ & & & ${ }^{143} \mathrm{La}$ & $6.4 \mathrm{E}-3$ & $3.1 \mathrm{E}-3$ & $0.0 \mathrm{E}+0$ & $0.0 \mathrm{E}+0$ & $0.0 \mathrm{E}+0$ \\
\hline & $\checkmark$ & $\sqrt{ }$ & & ${ }^{136} \mathrm{Cs}$ & $4.2 \mathrm{E}-4$ & $8.7 \mathrm{E}-4$ & $2.4 \mathrm{E}-3$ & $1.7 \mathrm{E}-3$ & $1.3 \mathrm{E}-13$ \\
\hline & $\checkmark$ & & & ${ }^{149} \mathrm{Nd}$ & $1.8 \mathrm{E}-3$ & $3.0 \mathrm{E}-3$ & $1.6 \mathrm{E}-23$ & $0.0 \mathrm{E}+0$ & $0.0 \mathrm{E}+0$ \\
\hline & $\checkmark$ & & & ${ }^{131} \mathrm{Sb}$ & $3.5 \mathrm{E}-3$ & $3.0 \mathrm{E}-3$ & $0.0 \mathrm{E}+0$ & $0.0 \mathrm{E}+0$ & $0.0 \mathrm{E}+0$ \\
\hline & $\checkmark$ & & & ${ }^{87} \mathrm{Kr}$ & $1.9 \mathrm{E}-3$ & $3.0 \mathrm{E}-3$ & $0.0 \mathrm{E}+0$ & $0.0 \mathrm{E}+0$ & $0.0 \mathrm{E}+0$ \\
\hline & $\checkmark$ & & & ${ }^{129} \mathrm{Te}$ & $1.3 \mathrm{E}-3$ & $2.6 \mathrm{E}-3$ & $8.1 \mathrm{E}-4$ & $1.1 \mathrm{E}-3$ & $3.5 \mathrm{E}-7$ \\
\hline & $\checkmark$ & & & ${ }^{133} \mathrm{Te}$ & $4.6 \mathrm{E}-3$ & $2.9 \mathrm{E}-3$ & $0.0 \mathrm{E}+0$ & $0.0 \mathrm{E}+0$ & $0.0 \mathrm{E}+0$ \\
\hline & $\checkmark$ & & & ${ }^{129} \mathrm{Sb}$ & $1.4 \mathrm{E}-3$ & $2.6 \mathrm{E}-3$ & $6.2 \mathrm{E}-11$ & $0.0 \mathrm{E}+0$ & $0.0 \mathrm{E}+0$ \\
\hline & $\checkmark$ & & & ${ }^{155} \mathrm{Eu}$ & $3.5 \mathrm{E}-5$ & $7.2 \mathrm{E}-5$ & $2.6 \mathrm{E}-4$ & $5.3 \mathrm{E}-4$ & $2.5 \mathrm{E}-3$ \\
\hline & $\checkmark$ & & & ${ }^{102} \mathrm{Tc}$ & $7.6 \mathrm{E}-3$ & $2.5 \mathrm{E}-3$ & $0.0 \mathrm{E}+0$ & $0.0 \mathrm{E}+0$ & $0.0 \mathrm{E}+0$ \\
\hline & $\checkmark$ & & & ${ }^{102} \mathrm{Mo}$ & $7.6 \mathrm{E}-3$ & $2.5 \mathrm{E}-3$ & $0.0 \mathrm{E}+0$ & $0.0 \mathrm{E}+0$ & $0.0 \mathrm{E}+0$ \\
\hline & $\checkmark$ & & & 148mPm & $2.0 \mathrm{E}-4$ & $4.1 \mathrm{E}-4$ & $1.3 \mathrm{E}-3$ & $2.0 \mathrm{E}-3$ & $3.8 \mathrm{E}-6$ \\
\hline & $\checkmark$ & & & ${ }^{129 \mathrm{~m}} \mathrm{Te}$ & $1.9 \mathrm{E}-4$ & $4.0 \mathrm{E}-4$ & $1.3 \mathrm{E}-3$ & $1.8 \mathrm{E}-3$ & $5.5 \mathrm{E}-7$ \\
\hline & $\checkmark$ & & & ${ }^{89} \mathrm{Rb}$ & $3.3 \mathrm{E}-3$ & $2.2 \mathrm{E}-3$ & $0.0 \mathrm{E}+0$ & $0.0 \mathrm{E}+0$ & $0.0 \mathrm{E}+0$ \\
\hline & $\checkmark$ & & & ${ }^{151} \mathrm{Pm}$ & $9.5 \mathrm{E}-4$ & $1.9 \mathrm{E}-3$ & $3.7 \mathrm{E}-4$ & $6.3 \mathrm{E}-9$ & $0.0 \mathrm{E}+0$ \\
\hline & $\checkmark$ & & & ${ }^{131 \mathrm{~m}} \mathrm{Te}$ & $9.1 \mathrm{E}-4$ & $1.9 \mathrm{E}-3$ & $5.5 \mathrm{E}-4$ & $5.1 \mathrm{E}-8$ & $0.0 \mathrm{E}+0$ \\
\hline & $\checkmark$ & & & ${ }^{85 \mathrm{~m}} \mathrm{Kr}$ & $1.0 \mathrm{E}-3$ & $1.9 \mathrm{E}-3$ & $6.4 \mathrm{E}-11$ & $0.0 \mathrm{E}+0$ & $0.0 \mathrm{E}+0$ \\
\hline & $\checkmark$ & & & ${ }^{127} \mathrm{Te}$ & $4.3 \mathrm{E}-4$ & $8.8 \mathrm{E}-4$ & $1.6 \mathrm{E}-3$ & 5.9E-4 & $1.4 \mathrm{E}-4$ \\
\hline & $\checkmark$ & & & ${ }^{142} \mathrm{Ba}$ & $6.5 \mathrm{E}-3$ & $1.9 \mathrm{E}-3$ & $0.0 \mathrm{E}+0$ & $0.0 \mathrm{E}+0$ & $0.0 \mathrm{E}+0$ \\
\hline & $\checkmark$ & & & ${ }^{95} \mathrm{Y}$ & $6.7 \mathrm{E}-3$ & $1.9 \mathrm{E}-3$ & $0.0 \mathrm{E}+0$ & $0.0 \mathrm{E}+0$ & $0.0 \mathrm{E}+0$ \\
\hline & $\checkmark$ & & & ${ }^{139} \mathrm{Cs}$ & $7.7 \mathrm{E}-3$ & $1.8 \mathrm{E}-3$ & $0.0 \mathrm{E}+0$ & $0.0 \mathrm{E}+0$ & $0.0 \mathrm{E}+0$ \\
\hline & $\checkmark$ & & & ${ }^{127} \mathrm{Sb}$ & $4.7 \mathrm{E}-4$ & $9.6 \mathrm{E}-4$ & $1.4 \mathrm{E}-3$ & $8.0 \mathrm{E}-5$ & $0.0 \mathrm{E}+0$ \\
\hline & $\checkmark$ & & & ${ }_{144 \mathrm{~m}} \mathrm{Pr}$ & $8.3 \mathrm{E}-5$ & $1.2 \mathrm{E}-4$ & $4.1 \mathrm{E}-4$ & $8.1 \mathrm{E}-4$ & $1.4 \mathrm{E}-3$ \\
\hline & $\checkmark$ & & & ${ }^{146} \mathrm{Ce}$ & $3.6 \mathrm{E}-3$ & $1.6 \mathrm{E}-3$ & $0.0 \mathrm{E}+0$ & $0.0 \mathrm{E}+0$ & $0.0 \mathrm{E}+0$ \\
\hline & $\checkmark$ & & & ${ }^{242} \mathrm{Am}$ & $7.5 \mathrm{E}-4$ & $1.5 \mathrm{E}-3$ & $3.1 \mathrm{E}-5$ & $9.1 \mathrm{E}-7$ & $5.1 \mathrm{E}-6$ \\
\hline & $\checkmark$ & & & ${ }^{130} \mathrm{Sb}$ & $1.2 \mathrm{E}-3$ & $1.5 \mathrm{E}-3$ & $0.0 \mathrm{E}+0$ & $0.0 \mathrm{E}+0$ & $0.0 \mathrm{E}+0$ \\
\hline & $\checkmark$ & & & ${ }^{244 m} \mathrm{Am}$ & $1.6 \mathrm{E}-3$ & $1.4 \mathrm{E}-3$ & $0.0 \mathrm{E}+0$ & $0.0 \mathrm{E}+0$ & $0.0 \mathrm{E}+0$ \\
\hline & $\checkmark$ & & & ${ }^{147} \mathrm{Pr}$ & $2.9 \mathrm{E}-3$ & $1.3 \mathrm{E}-3$ & $0.0 \mathrm{E}+0$ & $0.0 \mathrm{E}+0$ & $0.0 \mathrm{E}+0$ \\
\hline & $\checkmark$ & & & ${ }^{128 \mathrm{~m}} \mathrm{Sb}$ & $6.9 \mathrm{E}-4$ & $1.1 \mathrm{E}-3$ & $0.0 \mathrm{E}+0$ & $0.0 \mathrm{E}+0$ & $0.0 \mathrm{E}+0$ \\
\hline & $\checkmark$ & & & $95 \mathrm{~m} \mathrm{Nb}$ & $7.5 \mathrm{E}-5$ & $1.5 \mathrm{E}-4$ & $5.3 \mathrm{E}-4$ & $9.2 \mathrm{E}-4$ & $3.0 \mathrm{E}-5$ \\
\hline
\end{tabular}


Table A.2. Fractional contributions of istopes to total activity of $60 \mathrm{GWd} / \mathrm{MTU} 8 \mathrm{wt} \%$

\begin{tabular}{|l|c|c|r|r|r|}
\cline { 2 - 6 } \multicolumn{1}{c|}{} & \multicolumn{1}{c|}{$\mathbf{0 ~ s}$} & $\mathbf{3 0 ~} \mathbf{~ m}$ & \multicolumn{1}{c|}{$\mathbf{5 ~ d}$} & \multicolumn{1}{c|}{$\mathbf{2 5 ~ d}$} & \multicolumn{1}{c|}{$\mathbf{5 0 0 ~ d}$} \\
\hline Total calculated (MCi/MTU) & 232.50 & 111.60 & 32.17 & 16.10 & 2.74 \\
\hline & & & & & \\
Total listed (MCi/MTU) & 124.34 & 100.73 & 31.23 & 15.96 & 2.73 \\
\hline
\end{tabular}

\begin{tabular}{|c|c|c|c|c|c|c|c|c|c|}
\hline \multirow{3}{*}{ 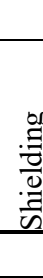 } & & & & & \multicolumn{5}{|c|}{ Fraction of activity from isotope } \\
\hline & 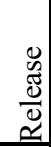 & 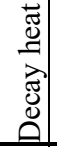 & 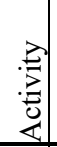 & $\begin{array}{l}\stackrel{0}{0} \\
\text { Oे. } \\
0 \\
0\end{array}$ & $0 \mathrm{~s}$ & $30 \mathrm{~m}$ & $5 \mathrm{~d}$ & $25 \mathrm{~d}$ & $500 \mathrm{~d}$ \\
\hline & $\checkmark$ & $\checkmark$ & $\checkmark$ & ${ }^{239} \mathrm{~Np}$ & $7.9 \mathrm{E}-2$ & $1.7 \mathrm{E}-1$ & $1.3 \mathrm{E}-1$ & $7.4 \mathrm{E}-4$ & $9.2 \mathrm{E}-6$ \\
\hline \multirow[t]{11}{*}{$\checkmark$} & $\checkmark$ & $\checkmark$ & $\checkmark$ & ${ }^{144} \mathrm{Pr}$ & $6.7 \mathrm{E}-3$ & $1.4 \mathrm{E}-2$ & 4.7E-2 & $9.0 \mathrm{E}-2$ & $1.7 \mathrm{E}-1$ \\
\hline & $\checkmark$ & & $\checkmark$ & ${ }^{144} \mathrm{Ce}$ & $6.6 \mathrm{E}-3$ & $1.4 \mathrm{E}-2$ & 4.7E-2 & $9.0 \mathrm{E}-2$ & $1.7 \mathrm{E}-1$ \\
\hline & $\checkmark$ & $\checkmark$ & $\checkmark$ & ${ }^{95} \mathrm{Nb}$ & $7.9 \mathrm{E}-3$ & $1.6 \mathrm{E}-2$ & $5.7 \mathrm{E}-2$ & $1.1 \mathrm{E}-1$ & $6.6 \mathrm{E}-3$ \\
\hline & $\checkmark$ & $\checkmark$ & $\checkmark$ & ${ }^{95} \mathrm{Zr}$ & 7.9E-3 & $1.6 \mathrm{E}-2$ & $5.4 \mathrm{E}-2$ & $8.7 \mathrm{E}-2$ & $3.0 \mathrm{E}-3$ \\
\hline & $\checkmark$ & & $\checkmark$ & ${ }^{106} \mathrm{Ru}$ & $2.7 \mathrm{E}-3$ & $5.6 \mathrm{E}-3$ & $1.9 \mathrm{E}-2$ & $3.7 \mathrm{E}-2$ & $8.9 \mathrm{E}-2$ \\
\hline & $\checkmark$ & & $\checkmark$ & ${ }^{106} \mathrm{Ru}$ & $2.7 \mathrm{E}-3$ & $5.6 \mathrm{E}-3$ & $1.9 \mathrm{E}-2$ & $3.7 \mathrm{E}-2$ & $8.9 \mathrm{E}-2$ \\
\hline & $\checkmark$ & & $\checkmark$ & ${ }^{141} \mathrm{Ce}$ & $7.7 \mathrm{E}-3$ & $1.6 \mathrm{E}-2$ & $5.0 \mathrm{E}-2$ & $6.5 \mathrm{E}-2$ & $1.5 \mathrm{E}-5$ \\
\hline & $\checkmark$ & $\checkmark$ & $\checkmark$ & ${ }^{103} \mathrm{Ru}$ & $7.1 \mathrm{E}-3$ & $1.5 \mathrm{E}-2$ & 4.7E-2 & $6.6 \mathrm{E}-2$ & $8.8 \mathrm{E}-5$ \\
\hline & $\checkmark$ & & $\checkmark$ & ${ }^{103 \mathrm{~m} R h}$ & $7.0 \mathrm{E}-3$ & $1.5 \mathrm{E}-2$ & $4.6 \mathrm{E}-2$ & $6.5 \mathrm{E}-2$ & $8.7 \mathrm{E}-5$ \\
\hline & $\checkmark$ & & $\checkmark$ & ${ }^{241} \mathrm{Pu}$ & $9.6 \mathrm{E}-4$ & $2.0 \mathrm{E}-3$ & $6.9 \mathrm{E}-3$ & $1.4 \mathrm{E}-2$ & $7.6 \mathrm{E}-2$ \\
\hline & $\checkmark$ & $\checkmark$ & $\checkmark$ & ${ }^{91} \mathrm{Y}$ & $5.9 \mathrm{E}-3$ & $1.2 \mathrm{E}-2$ & $4.0 \mathrm{E}-2$ & $6.4 \mathrm{E}-2$ & $1.3 \mathrm{E}-3$ \\
\hline \multirow[t]{3}{*}{$\checkmark$} & $\checkmark$ & $\checkmark$ & $\checkmark$ & ${ }^{134} \mathrm{Cs}$ & $1.3 \mathrm{E}-3$ & $2.7 \mathrm{E}-3$ & $9.3 \mathrm{E}-3$ & $1.8 \mathrm{E}-2$ & $6.9 \mathrm{E}-2$ \\
\hline & $\checkmark$ & & $\checkmark$ & ${ }^{147} \mathrm{Pm}$ & $1.1 \mathrm{E}-3$ & $2.3 \mathrm{E}-3$ & $8.0 \mathrm{E}-3$ & $1.6 \mathrm{E}-2$ & $6.7 \mathrm{E}-2$ \\
\hline & $\checkmark$ & $\checkmark$ & $\checkmark$ & ${ }^{137} \mathrm{Cs}$ & $8.1 \mathrm{E}-4$ & $1.7 \mathrm{E}-3$ & $5.9 \mathrm{E}-3$ & $1.2 \mathrm{E}-2$ & $6.7 \mathrm{E}-2$ \\
\hline \multirow[t]{5}{*}{$\checkmark$} & $\checkmark$ & $\checkmark$ & $\checkmark$ & ${ }^{137 m} \mathrm{Ba}$ & 7.7E-4 & $1.6 \mathrm{E}-3$ & $5.6 \mathrm{E}-3$ & $1.1 \mathrm{E}-2$ & $6.3 \mathrm{E}-2$ \\
\hline & $\checkmark$ & $\checkmark$ & $\checkmark$ & ${ }^{140} \mathrm{La}$ & $8.4 \mathrm{E}-3$ & $1.8 \mathrm{E}-2$ & $5.1 \mathrm{E}-2$ & $3.5 \mathrm{E}-2$ & $1.3 \mathrm{E}-12$ \\
\hline & $\checkmark$ & & & ${ }^{143} \mathrm{Pr}$ & $7.3 \mathrm{E}-3$ & $1.5 \mathrm{E}-2$ & $4.5 \mathrm{E}-2$ & $3.3 \mathrm{E}-2$ & $5.6 \mathrm{E}-12$ \\
\hline & $\checkmark$ & & $\checkmark$ & ${ }^{140} \mathrm{Ba}$ & $8.2 \mathrm{E}-3$ & $1.7 \mathrm{E}-2$ & $4.5 \mathrm{E}-2$ & $3.0 \mathrm{E}-2$ & $1.1 \mathrm{E}-12$ \\
\hline & $\checkmark$ & $\checkmark$ & $\checkmark$ & ${ }^{89} \mathrm{Sr}$ & $4.5 \mathrm{E}-3$ & $9.5 \mathrm{E}-3$ & $3.1 \mathrm{E}-2$ & $4.7 \mathrm{E}-2$ & $4.1 \mathrm{E}-4$ \\
\hline \multirow[t]{19}{*}{$\checkmark$} & $\checkmark$ & $\checkmark$ & & ${ }^{90} \mathrm{Y}$ & $6.4 \mathrm{E}-4$ & $1.3 \mathrm{E}-3$ & $4.5 \mathrm{E}-3$ & $9.0 \mathrm{E}-3$ & $5.1 \mathrm{E}-2$ \\
\hline & $\checkmark$ & $\checkmark$ & $\checkmark$ & ${ }^{90} \mathrm{Sr}$ & $6.2 \mathrm{E}-4$ & $1.3 \mathrm{E}-3$ & $4.5 \mathrm{E}-3$ & $9.0 \mathrm{E}-3$ & $5.1 \mathrm{E}-2$ \\
\hline & $\checkmark$ & & $\checkmark$ & ${ }^{133} \mathrm{Xe}$ & $9.1 \mathrm{E}-3$ & $1.9 \mathrm{E}-2$ & 4.1E-2 & $6.0 \mathrm{E}-3$ & $0.0 \mathrm{E}+0$ \\
\hline & $\checkmark$ & & & ${ }^{131} \mathrm{I}$ & $4.6 \mathrm{E}-3$ & $9.6 \mathrm{E}-3$ & $2.2 \mathrm{E}-2$ & $8.0 \mathrm{E}-3$ & $7.2 \mathrm{E}-20$ \\
\hline & $\checkmark$ & & $\checkmark$ & ${ }^{99} \mathrm{Mo}$ & $8.7 \mathrm{E}-3$ & $1.8 \mathrm{E}-2$ & $1.8 \mathrm{E}-2$ & $2.3 \mathrm{E}-4$ & $0.0 \mathrm{E}+0$ \\
\hline & $\checkmark$ & & & ${ }^{99 \mathrm{~m}} \mathrm{Tc}$ & $7.7 \mathrm{E}-3$ & $1.6 \mathrm{E}-2$ & $1.7 \mathrm{E}-2$ & $2.2 \mathrm{E}-4$ & $0.0 \mathrm{E}+0$ \\
\hline & $\checkmark$ & & & ${ }^{132} \mathrm{I}$ & $6.7 \mathrm{E}-3$ & $1.4 \mathrm{E}-2$ & $1.7 \mathrm{E}-2$ & $4.4 \mathrm{E}-4$ & $0.0 \mathrm{E}+0$ \\
\hline & $\checkmark$ & & & ${ }^{132} \mathrm{Te}$ & $6.6 \mathrm{E}-3$ & $1.4 \mathrm{E}-2$ & $1.6 \mathrm{E}-2$ & $4.2 \mathrm{E}-4$ & $0.0 \mathrm{E}+0$ \\
\hline & $\checkmark$ & & $\checkmark$ & ${ }^{133} \mathrm{I}$ & $9.5 \mathrm{E}-3$ & $2.0 \mathrm{E}-2$ & $1.3 \mathrm{E}-3$ & $2.9 \mathrm{E}-10$ & $0.0 \mathrm{E}+0$ \\
\hline & $\checkmark$ & & $\checkmark$ & ${ }^{134} \mathrm{I}$ & $1.1 \mathrm{E}-2$ & $2.0 \mathrm{E}-2$ & $0.0 \mathrm{E}+0$ & $0.0 \mathrm{E}+0$ & $0.0 \mathrm{E}+0$ \\
\hline & $\checkmark$ & & & ${ }^{147} \mathrm{Nd}$ & $3.1 \mathrm{E}-3$ & $6.4 \mathrm{E}-3$ & $1.6 \mathrm{E}-2$ & $9.1 \mathrm{E}-3$ & $5.1 \mathrm{E}-15$ \\
\hline & $\checkmark$ & & $\checkmark$ & ${ }^{135} \mathrm{I}$ & $9.1 \mathrm{E}-3$ & $1.8 \mathrm{E}-2$ & $2.1 \mathrm{E}-7$ & $0.0 \mathrm{E}+0$ & $0.0 \mathrm{E}+0$ \\
\hline & $\checkmark$ & & $\checkmark$ & ${ }^{97} \mathrm{Nb}$ & $8.0 \mathrm{E}-3$ & $1.7 \mathrm{E}-2$ & $4.0 \mathrm{E}-4$ & $2.0 \mathrm{E}-12$ & $0.0 \mathrm{E}+0$ \\
\hline & $\checkmark$ & & & ${ }^{97} \mathrm{Zr}$ & 7.9E-3 & $1.6 \mathrm{E}-2$ & $4.0 \mathrm{E}-4$ & $1.9 \mathrm{E}-12$ & $0.0 \mathrm{E}+0$ \\
\hline & $\checkmark$ & & & ${ }^{143} \mathrm{Ce}$ & $7.3 \mathrm{E}-3$ & $1.5 \mathrm{E}-2$ & $4.3 \mathrm{E}-3$ & $3.6 \mathrm{E}-7$ & $0.0 \mathrm{E}+0$ \\
\hline & $\checkmark$ & & & ${ }^{141} \mathrm{La}$ & 7.7E-3 & $1.5 \mathrm{E}-2$ & $3.7 \mathrm{E}-11$ & $0.0 \mathrm{E}+0$ & $0.0 \mathrm{E}+0$ \\
\hline & $\checkmark$ & & & ${ }^{97 \mathrm{~m}} \mathrm{Nb}$ & $7.5 \mathrm{E}-3$ & $1.5 \mathrm{E}-2$ & $3.8 \mathrm{E}-4$ & $1.8 \mathrm{E}-12$ & $0.0 \mathrm{E}+0$ \\
\hline & $\checkmark$ & & & ${ }^{139} \mathrm{Ba}$ & $8.5 \mathrm{E}-3$ & $1.5 \mathrm{E}-2$ & $0.0 \mathrm{E}+0$ & $0.0 \mathrm{E}+0$ & $0.0 \mathrm{E}+0$ \\
\hline & $\checkmark$ & & & ${ }^{93} \mathrm{Y}$ & $7.0 \mathrm{E}-3$ & $1.4 \mathrm{E}-2$ & $1.4 \mathrm{E}-5$ & $1.8 \mathrm{E}-19$ & $0.0 \mathrm{E}+0$ \\
\hline
\end{tabular}




\begin{tabular}{|c|c|c|c|c|c|c|c|c|c|}
\hline \multirow[b]{2}{*}{ 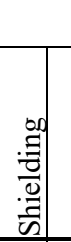 } & \multirow[b]{2}{*}{ 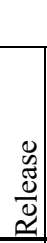 } & \multirow[b]{2}{*}{ 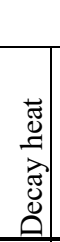 } & \multirow[b]{2}{*}{ 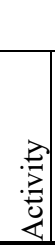 } & \multirow[b]{2}{*}{ 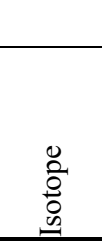 } & \multicolumn{5}{|c|}{ Fraction of activity from isotope } \\
\hline & & & & & $0 \mathrm{~s}$ & $30 \mathrm{~m}$ & $5 \mathrm{~d}$ & $25 \mathrm{~d}$ & $500 \mathrm{~d}$ \\
\hline & $\checkmark$ & & & ${ }^{138} \mathrm{Cs}$ & $8.9 \mathrm{E}-3$ & $1.4 \mathrm{E}-2$ & $0.0 \mathrm{E}+0$ & $0.0 \mathrm{E}+0$ & $0.0 \mathrm{E}+0$ \\
\hline & $\checkmark$ & & & ${ }^{142} \mathrm{La}$ & $7.4 \mathrm{E}-3$ & $1.4 \mathrm{E}-2$ & $0.0 \mathrm{E}+0$ & $0.0 \mathrm{E}+0$ & $0.0 \mathrm{E}+0$ \\
\hline & $\checkmark$ & & & ${ }^{92} \mathrm{Y}$ & $6.2 \mathrm{E}-3$ & $1.3 \mathrm{E}-2$ & $1.2 \mathrm{E}-11$ & $0.0 \mathrm{E}+0$ & $0.0 \mathrm{E}+0$ \\
\hline & $\checkmark$ & & & ${ }^{91} \mathrm{Sr}$ & $5.8 \mathrm{E}-3$ & $1.2 \mathrm{E}-2$ & $7.4 \mathrm{E}-6$ & $1.5 \mathrm{E}-20$ & $0.0 \mathrm{E}+0$ \\
\hline & $\checkmark$ & & & ${ }^{92} \mathrm{Sr}$ & $6.2 \mathrm{E}-3$ & $1.1 \mathrm{E}-2$ & $2.1 \mathrm{E}-15$ & $0.0 \mathrm{E}+0$ & $0.0 \mathrm{E}+0$ \\
\hline & $\checkmark$ & & & ${ }^{134} \mathrm{Te}$ & $8.6 \mathrm{E}-3$ & $1.1 \mathrm{E}-2$ & $0.0 \mathrm{E}+0$ & $0.0 \mathrm{E}+0$ & $0.0 \mathrm{E}+0$ \\
\hline & $\checkmark$ & & & ${ }^{105} \mathrm{Rh}$ & $4.4 \mathrm{E}-3$ & $9.2 \mathrm{E}-3$ & $3.5 \mathrm{E}-3$ & $5.8 \mathrm{E}-7$ & $0.0 \mathrm{E}+0$ \\
\hline & $\checkmark$ & & & ${ }^{145} \mathrm{Pr}$ & $4.9 \mathrm{E}-3$ & $9.8 \mathrm{E}-3$ & $3.3 \mathrm{E}-8$ & $0.0 \mathrm{E}+0$ & $0.0 \mathrm{E}+0$ \\
\hline & $\checkmark$ & & & ${ }^{101} \mathrm{Tc}$ & $8.0 \mathrm{E}-3$ & $9.6 \mathrm{E}-3$ & $0.0 \mathrm{E}+0$ & $0.0 \mathrm{E}+0$ & $0.0 \mathrm{E}+0$ \\
\hline & $\checkmark$ & & & ${ }^{105} \mathrm{Ru}$ & $4.8 \mathrm{E}-3$ & $9.4 \mathrm{E}-3$ & $2.6 \mathrm{E}-10$ & $0.0 \mathrm{E}+0$ & $0.0 \mathrm{E}+0$ \\
\hline & $\checkmark$ & $\checkmark$ & & ${ }^{156} \mathrm{Eu}$ & $1.2 \mathrm{E}-3$ & $2.4 \mathrm{E}-3$ & $6.8 \mathrm{E}-3$ & $5.4 \mathrm{E}-3$ & $1.2 \mathrm{E}-11$ \\
\hline & $\checkmark$ & & & ${ }^{135} \mathrm{Xe}$ & $4.0 \mathrm{E}-3$ & $8.7 \mathrm{E}-3$ & $2.2 \mathrm{E}-5$ & $6.8 \mathrm{E}-21$ & $0.0 \mathrm{E}+0$ \\
\hline & $\checkmark$ & $\checkmark$ & & ${ }^{238} \mathrm{~Np}$ & $3.0 \mathrm{E}-3$ & $6.2 \mathrm{E}-3$ & $4.2 \mathrm{E}-3$ & $1.2 \mathrm{E}-5$ & $3.1 \mathrm{E}-8$ \\
\hline & $\checkmark$ & & & ${ }^{91 \mathrm{~m} Y}$ & $3.4 \mathrm{E}-3$ & $7.0 \mathrm{E}-3$ & $4.8 \mathrm{E}-6$ & $9.4 \mathrm{E}-21$ & $0.0 \mathrm{E}+0$ \\
\hline & $\checkmark$ & & & ${ }^{133 \mathrm{~m}} \mathrm{Te}$ & $4.8 \mathrm{E}-3$ & $6.9 \mathrm{E}-3$ & $0.0 \mathrm{E}+0$ & $0.0 \mathrm{E}+0$ & $0.0 \mathrm{E}+0$ \\
\hline & $\checkmark$ & & & ${ }^{88} \mathrm{Rb}$ & $3.4 \mathrm{E}-3$ & $6.6 \mathrm{E}-3$ & $5.1 \mathrm{E}-15$ & $0.0 \mathrm{E}+0$ & $0.0 \mathrm{E}+0$ \\
\hline & $\checkmark$ & $\checkmark$ & & ${ }^{242} \mathrm{Cm}$ & $3.6 \mathrm{E}-4$ & $7.4 \mathrm{E}-4$ & $2.5 \mathrm{E}-3$ & $4.7 \mathrm{E}-3$ & $3.6 \mathrm{E}-3$ \\
\hline & $\checkmark$ & & & ${ }^{131} \mathrm{Te}$ & $4.0 \mathrm{E}-3$ & $6.4 \mathrm{E}-3$ & $1.3 \mathrm{E}-4$ & $1.2 \mathrm{E}-8$ & $0.0 \mathrm{E}+0$ \\
\hline & $\checkmark$ & & & ${ }^{149} \mathrm{Pm}$ & $2.4 \mathrm{E}-3$ & $5.0 \mathrm{E}-3$ & $3.7 \mathrm{E}-3$ & $1.4 \mathrm{E}-5$ & $0.0 \mathrm{E}+0$ \\
\hline & $\checkmark$ & & & ${ }^{85} \mathrm{Kr}$ & $7.8 \mathrm{E}-5$ & $1.6 \mathrm{E}-4$ & $5.6 \mathrm{E}-4$ & $1.1 \mathrm{E}-3$ & $6.1 \mathrm{E}-3$ \\
\hline & $\checkmark$ & & & ${ }^{88} \mathrm{Kr}$ & $3.3 \mathrm{E}-3$ & $6.1 \mathrm{E}-3$ & 4.6E-15 & $0.0 \mathrm{E}+0$ & $0.0 \mathrm{E}+0$ \\
\hline & $\checkmark$ & & & ${ }^{146} \mathrm{Pr}$ & $3.9 \mathrm{E}-3$ & $5.6 \mathrm{E}-3$ & $0.0 \mathrm{E}+0$ & $0.0 \mathrm{E}+0$ & $0.0 \mathrm{E}+0$ \\
\hline & $\checkmark$ & & & ${ }^{94} \mathrm{Y}$ & $7.3 \mathrm{E}-3$ & $5.4 \mathrm{E}-3$ & $0.0 \mathrm{E}+0$ & $0.0 \mathrm{E}+0$ & $0.0 \mathrm{E}+0$ \\
\hline & $\checkmark$ & & & ${ }^{153} \mathrm{Sm}$ & $2.2 \mathrm{E}-3$ & $4.5 \mathrm{E}-3$ & $2.6 \mathrm{E}-3$ & $4.1 \mathrm{E}-6$ & $0.0 \mathrm{E}+0$ \\
\hline & $\checkmark$ & & & ${ }^{141} \mathrm{Ba}$ & $7.6 \mathrm{E}-3$ & $5.2 \mathrm{E}-3$ & $0.0 \mathrm{E}+0$ & $0.0 \mathrm{E}+0$ & $0.0 \mathrm{E}+0$ \\
\hline \multirow[t]{13}{*}{$\checkmark$} & $\checkmark$ & $\checkmark$ & & ${ }^{154} \mathrm{Eu}$ & $6.4 \mathrm{E}-5$ & $1.3 \mathrm{E}-4$ & 4.6E-4 & $9.2 \mathrm{E}-4$ & 4.9E-3 \\
\hline & $\checkmark$ & & & ${ }^{148} \mathrm{Pm}$ & $1.0 \mathrm{E}-3$ & $2.1 \mathrm{E}-3$ & $3.9 \mathrm{E}-3$ & $7.0 \mathrm{E}-4$ & $2.6 \mathrm{E}-7$ \\
\hline & $\checkmark$ & $\checkmark$ & & ${ }^{104} \mathrm{Tc}$ & $5.8 \mathrm{E}-3$ & $4.1 \mathrm{E}-3$ & $0.0 \mathrm{E}+0$ & $0.0 \mathrm{E}+0$ & $0.0 \mathrm{E}+0$ \\
\hline & $\checkmark$ & & & ${ }^{101} \mathrm{Mo}$ & $8.0 \mathrm{E}-3$ & $4.0 \mathrm{E}-3$ & $0.0 \mathrm{E}+0$ & $0.0 \mathrm{E}+0$ & $0.0 \mathrm{E}+0$ \\
\hline & $\checkmark$ & & & ${ }^{87} \mathrm{Kr}$ & $2.5 \mathrm{E}-3$ & $3.9 \mathrm{E}-3$ & $0.0 \mathrm{E}+0$ & $0.0 \mathrm{E}+0$ & $0.0 \mathrm{E}+0$ \\
\hline & $\checkmark$ & & & ${ }^{138} \mathrm{Xe}$ & $8.1 \mathrm{E}-3$ & $3.9 \mathrm{E}-3$ & $0.0 \mathrm{E}+0$ & $0.0 \mathrm{E}+0$ & $0.0 \mathrm{E}+0$ \\
\hline & $\checkmark$ & & & ${ }^{125} \mathrm{Sb}$ & $5.9 \mathrm{E}-5$ & $1.2 \mathrm{E}-4$ & 4.3E-4 & $8.4 \mathrm{E}-4$ & $3.6 \mathrm{E}-3$ \\
\hline & $\checkmark$ & & & ${ }^{143} \mathrm{La}$ & $7.2 \mathrm{E}-3$ & $3.5 \mathrm{E}-3$ & $0.0 \mathrm{E}+0$ & $0.0 \mathrm{E}+0$ & $0.0 \mathrm{E}+0$ \\
\hline & $\checkmark$ & & & ${ }^{135 \mathrm{~m}} \mathrm{Xe}$ & $2.0 \mathrm{E}-3$ & $3.3 \mathrm{E}-3$ & $3.6 \mathrm{E}-8$ & $0.0 \mathrm{E}+0$ & $0.0 \mathrm{E}+0$ \\
\hline & $\checkmark$ & $\checkmark$ & & ${ }^{136} \mathrm{Cs}$ & $4.6 \mathrm{E}-4$ & $9.6 \mathrm{E}-4$ & $2.6 \mathrm{E}-3$ & $1.8 \mathrm{E}-3$ & $1.4 \mathrm{E}-13$ \\
\hline & $\checkmark$ & & & 148m Pm & $2.8 \mathrm{E}-4$ & $5.7 \mathrm{E}-4$ & $1.8 \mathrm{E}-3$ & $2.6 \mathrm{E}-3$ & $5.3 \mathrm{E}-6$ \\
\hline & $\checkmark$ & & & ${ }^{133} \mathrm{Te}$ & $4.8 \mathrm{E}-3$ & $3.2 \mathrm{E}-3$ & $0.0 \mathrm{E}+0$ & $0.0 \mathrm{E}+0$ & $0.0 \mathrm{E}+0$ \\
\hline & $\checkmark$ & & & ${ }^{131} \mathrm{Sb}$ & $3.7 \mathrm{E}-3$ & $3.2 \mathrm{E}-3$ & $0.0 \mathrm{E}+0$ & $0.0 \mathrm{E}+0$ & $0.0 \mathrm{E}+0$ \\
\hline \multirow[t]{8}{*}{$\checkmark$} & $\checkmark$ & $\checkmark$ & & ${ }^{238} \mathrm{Pu}$ & $3.5 \mathrm{E}-5$ & 7.3E-5 & $2.6 \mathrm{E}-4$ & $5.1 \mathrm{E}-4$ & $3.1 \mathrm{E}-3$ \\
\hline & $\checkmark$ & & & ${ }^{149} \mathrm{Nd}$ & $1.8 \mathrm{E}-3$ & $3.1 \mathrm{E}-3$ & $1.6 \mathrm{E}-23$ & $0.0 \mathrm{E}+0$ & $0.0 \mathrm{E}+0$ \\
\hline & $\checkmark$ & & & ${ }^{243} \mathrm{Pu}$ & $1.5 \mathrm{E}-3$ & $3.0 \mathrm{E}-3$ & $5.8 \mathrm{E}-10$ & $2.8 \mathrm{E}-14$ & $1.7 \mathrm{E}-13$ \\
\hline & $\checkmark$ & & & ${ }^{109} \mathrm{Pd}$ & $1.5 \mathrm{E}-3$ & $3.0 \mathrm{E}-3$ & $2.4 \mathrm{E}-5$ & $1.4 \mathrm{E}-15$ & $0.0 \mathrm{E}+0$ \\
\hline & $\checkmark$ & & & ${ }^{89} \mathrm{Rb}$ & $4.4 \mathrm{E}-3$ & $2.9 \mathrm{E}-3$ & $0.0 \mathrm{E}+0$ & $0.0 \mathrm{E}+0$ & $0.0 \mathrm{E}+0$ \\
\hline & $\checkmark$ & & & ${ }^{129} \mathrm{Te}$ & $1.2 \mathrm{E}-3$ & $2.5 \mathrm{E}-3$ & 7.9E-4 & $1.0 \mathrm{E}-3$ & $3.4 \mathrm{E}-7$ \\
\hline & $\checkmark$ & & & ${ }^{105 \mathrm{~m}} \mathrm{Rh}$ & $1.3 \mathrm{E}-3$ & $2.7 \mathrm{E}-3$ & 7.4E-11 & $0.0 \mathrm{E}+0$ & $0.0 \mathrm{E}+0$ \\
\hline & $\checkmark$ & & & ${ }^{107} \mathrm{Rh}$ & $2.6 \mathrm{E}-3$ & $2.5 \mathrm{E}-3$ & $0.0 \mathrm{E}+0$ & $0.0 \mathrm{E}+0$ & $0.0 \mathrm{E}+0$ \\
\hline
\end{tabular}




\begin{tabular}{|c|c|c|c|c|c|c|c|c|c|}
\hline \multirow[b]{2}{*}{ 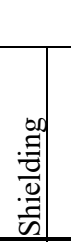 } & \multirow[b]{2}{*}{ 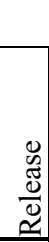 } & \multirow[b]{2}{*}{ 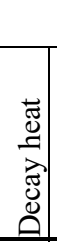 } & \multirow[b]{2}{*}{ 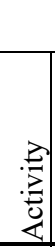 } & \multirow[b]{2}{*}{$\begin{array}{l}\mathscr{0} \\
0 \\
0 \\
0 \\
0 \\
0\end{array}$} & \multicolumn{5}{|c|}{ Fraction of activity from isotope } \\
\hline & & & & & $0 \mathrm{~s}$ & $30 \mathrm{~m}$ & $5 \mathrm{~d}$ & $25 \mathrm{~d}$ & $500 \mathrm{~d}$ \\
\hline & $\checkmark$ & & & ${ }^{85 \mathrm{~m} K r}$ & $1.3 \mathrm{E}-3$ & $2.5 \mathrm{E}-3$ & $8.1 \mathrm{E}-11$ & $0.0 \mathrm{E}+0$ & $0.0 \mathrm{E}+0$ \\
\hline & $\checkmark$ & & & ${ }^{102} \mathrm{Tc}$ & $7.4 \mathrm{E}-3$ & $2.5 \mathrm{E}-3$ & $0.0 \mathrm{E}+0$ & $0.0 \mathrm{E}+0$ & $0.0 \mathrm{E}+0$ \\
\hline & $\checkmark$ & & & ${ }^{129} \mathrm{Sb}$ & $1.3 \mathrm{E}-3$ & $2.5 \mathrm{E}-3$ & $5.7 \mathrm{E}-11$ & $0.0 \mathrm{E}+0$ & $0.0 \mathrm{E}+0$ \\
\hline & $\checkmark$ & & & ${ }^{102} \mathrm{Mo}$ & $7.4 \mathrm{E}-3$ & $2.5 \mathrm{E}-3$ & $0.0 \mathrm{E}+0$ & $0.0 \mathrm{E}+0$ & $0.0 \mathrm{E}+0$ \\
\hline & $\checkmark$ & & & ${ }^{155} \mathrm{Eu}$ & $3.1 \mathrm{E}-5$ & $6.5 \mathrm{E}-5$ & $2.2 \mathrm{E}-4$ & $4.5 \mathrm{E}-4$ & $2.2 \mathrm{E}-3$ \\
\hline & $\checkmark$ & & & ${ }^{95} \mathrm{Y}$ & $7.6 \mathrm{E}-3$ & $2.2 \mathrm{E}-3$ & $0.0 \mathrm{E}+0$ & $0.0 \mathrm{E}+0$ & $0.0 \mathrm{E}+0$ \\
\hline & $\checkmark$ & & & ${ }^{142} \mathrm{Ba}$ & $7.2 \mathrm{E}-3$ & $2.1 \mathrm{E}-3$ & $0.0 \mathrm{E}+0$ & $0.0 \mathrm{E}+0$ & $0.0 \mathrm{E}+0$ \\
\hline & $\checkmark$ & & & ${ }^{129 \mathrm{~m} T e}$ & $1.9 \mathrm{E}-4$ & $4.0 \mathrm{E}-4$ & $1.2 \mathrm{E}-3$ & $1.6 \mathrm{E}-3$ & $5.4 \mathrm{E}-7$ \\
\hline & $\checkmark$ & & & ${ }^{139} \mathrm{Cs}$ & $8.3 \mathrm{E}-3$ & $1.9 \mathrm{E}-3$ & $0.0 \mathrm{E}+0$ & $0.0 \mathrm{E}+0$ & $0.0 \mathrm{E}+0$ \\
\hline & $\checkmark$ & & & ${ }^{144 \mathrm{~m}} \operatorname{Pr}$ & $8.3 \mathrm{E}-5$ & $1.3 \mathrm{E}-4$ & $4.5 \mathrm{E}-4$ & $8.6 \mathrm{E}-4$ & $1.6 \mathrm{E}-3$ \\
\hline & $\checkmark$ & & & ${ }^{151} \mathrm{Pm}$ & $8.8 \mathrm{E}-4$ & $1.8 \mathrm{E}-3$ & $3.4 \mathrm{E}-4$ & $5.6 \mathrm{E}-9$ & $0.0 \mathrm{E}+0$ \\
\hline & $\checkmark$ & & & $131 \mathrm{~m} \mathrm{Te}$ & $8.6 \mathrm{E}-4$ & $1.8 \mathrm{E}-3$ & $5.1 \mathrm{E}-4$ & $4.6 \mathrm{E}-8$ & $0.0 \mathrm{E}+0$ \\
\hline & $\checkmark$ & & & ${ }^{127} \mathrm{Te}$ & $4.0 \mathrm{E}-4$ & $8.3 \mathrm{E}-4$ & $1.5 \mathrm{E}-3$ & $6.1 \mathrm{E}-4$ & $1.6 \mathrm{E}-4$ \\
\hline & $\checkmark$ & & & ${ }^{146} \mathrm{Ce}$ & $3.9 \mathrm{E}-3$ & $1.8 \mathrm{E}-3$ & $0.0 \mathrm{E}+0$ & $0.0 \mathrm{E}+0$ & $0.0 \mathrm{E}+0$ \\
\hline$\checkmark$ & $\checkmark$ & $\checkmark$ & & ${ }^{244} \mathrm{Cm}$ & $2.0 \mathrm{E}-5$ & $4.1 \mathrm{E}-5$ & $1.4 \mathrm{E}-4$ & $2.8 \mathrm{E}-4$ & $1.6 \mathrm{E}-3$ \\
\hline & $\checkmark$ & & & ${ }^{127} \mathrm{Sb}$ & $4.2 \mathrm{E}-4$ & $8.8 \mathrm{E}-4$ & $1.3 \mathrm{E}-3$ & $6.9 \mathrm{E}-5$ & $0.0 \mathrm{E}+0$ \\
\hline & $\checkmark$ & & & ${ }^{130} \mathrm{Sb}$ & $1.2 \mathrm{E}-3$ & $1.5 \mathrm{E}-3$ & $0.0 \mathrm{E}+0$ & $0.0 \mathrm{E}+0$ & $0.0 \mathrm{E}+0$ \\
\hline & $\checkmark$ & & & ${ }^{147} \mathrm{Pr}$ & $3.1 \mathrm{E}-3$ & $1.4 \mathrm{E}-3$ & $0.0 \mathrm{E}+0$ & $0.0 \mathrm{E}+0$ & $0.0 \mathrm{E}+0$ \\
\hline & $\checkmark$ & & & ${ }^{242} \mathrm{Am}$ & $6.0 \mathrm{E}-4$ & $1.2 \mathrm{E}-3$ & $2.5 \mathrm{E}-5$ & $1.1 \mathrm{E}-6$ & $6.7 \mathrm{E}-6$ \\
\hline & $\checkmark$ & & & ${ }^{84} \mathrm{Br}$ & $1.0 \mathrm{E}-3$ & $1.2 \mathrm{E}-3$ & $0.0 \mathrm{E}+0$ & $0.0 \mathrm{E}+0$ & $0.0 \mathrm{E}+0$ \\
\hline & $\checkmark$ & & & ${ }^{83 \mathrm{~m}} \mathrm{Kr}$ & $5.8 \mathrm{E}-4$ & $1.2 \mathrm{E}-3$ & $1.3 \mathrm{E}-10$ & $2.2 \mathrm{E}-10$ & $2.8 \mathrm{E}-11$ \\
\hline & $\checkmark$ & & & $95 \mathrm{~m} \mathrm{Nb}$ & $8.5 \mathrm{E}-5$ & $1.8 \mathrm{E}-4$ & $6.0 \mathrm{E}-4$ & $9.9 \mathrm{E}-4$ & $3.4 \mathrm{E}-5$ \\
\hline & $\checkmark$ & & & ${ }^{83} \mathrm{Br}$ & $5.8 \mathrm{E}-4$ & $1.1 \mathrm{E}-3$ & 4.3E-18 & $0.0 \mathrm{E}+0$ & $0.0 \mathrm{E}+0$ \\
\hline & $\checkmark$ & & & ${ }^{128 \mathrm{~m} S b}$ & $6.7 \mathrm{E}-4$ & $1.1 \mathrm{E}-3$ & $0.0 \mathrm{E}+0$ & $0.0 \mathrm{E}+0$ & $0.0 \mathrm{E}+0$ \\
\hline
\end{tabular}

Table A.3. Fractional contributions of istopes to total activity of $80 \mathrm{GWd} / \mathrm{MTU} 6.5 \mathrm{wt} \%$

\begin{tabular}{|r|c|c|r|r|r|}
\cline { 2 - 6 } \multicolumn{1}{c|}{} & \multicolumn{1}{c|}{$\mathbf{0 ~ s}$} & $\mathbf{3 0 ~} \mathbf{~ m}$ & \multicolumn{1}{c|}{$\mathbf{5 ~ d}$} & \multicolumn{1}{c|}{$\mathbf{2 5 ~ d}$} & \multicolumn{1}{c|}{$\mathbf{5 0 0 ~ d}$} \\
\hline Total calculated (MCi/MTU) & 241.30 & 118.60 & 33.91 & 16.55 & 3.26 \\
\hline Total listed (MCi/MTU) & 128.23 & 104.96 & 32.80 & 16.38 & 3.25 \\
\hline
\end{tabular}

\begin{tabular}{|c|c|c|c|c|c|c|c|c|c|}
\hline \multirow[b]{2}{*}{ 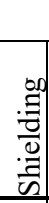 } & & & & & \multicolumn{5}{|c|}{ Fraction of activity from isotope } \\
\hline & 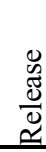 & 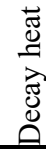 & 总 & $\begin{array}{l}0 \\
\text { مे } \\
0 \\
0 \\
0\end{array}$ & $0 \mathrm{~s}$ & $30 \mathrm{~m}$ & $5 \mathrm{~d}$ & $25 \mathrm{~d}$ & $500 \mathrm{~d}$ \\
\hline & $\checkmark$ & $\checkmark$ & $\checkmark$ & ${ }^{239} \mathrm{~Np}$ & $9.5 \mathrm{E}-2$ & $1.9 \mathrm{E}-1$ & $1.6 \mathrm{E}-1$ & $9.0 \mathrm{E}-4$ & $2.3 \mathrm{E}-5$ \\
\hline \multirow[t]{5}{*}{$\checkmark$} & $\checkmark$ & $\checkmark$ & $\checkmark$ & ${ }^{144} \mathrm{Pr}$ & $6.0 \mathrm{E}-3$ & $1.2 \mathrm{E}-2$ & $4.2 \mathrm{E}-2$ & $8.2 \mathrm{E}-2$ & $1.3 \mathrm{E}-1$ \\
\hline & $\checkmark$ & & $\checkmark$ & ${ }^{144} \mathrm{Ce}$ & $5.9 \mathrm{E}-3$ & $1.2 \mathrm{E}-2$ & $4.2 \mathrm{E}-2$ & $8.2 \mathrm{E}-2$ & $1.3 \mathrm{E}-1$ \\
\hline & $\checkmark$ & & $\checkmark$ & ${ }^{106} \mathrm{Ru}$ & $3.8 \mathrm{E}-3$ & 7.7E-3 & 2.7E-2 & $5.3 \mathrm{E}-2$ & $1.1 \mathrm{E}-1$ \\
\hline & $\checkmark$ & & $\checkmark$ & ${ }^{106} \mathrm{Ru}$ & $3.8 \mathrm{E}-3$ & 7.7E-3 & 2.7E-2 & $5.3 \mathrm{E}-2$ & $1.1 \mathrm{E}-1$ \\
\hline & $\checkmark$ & $\checkmark$ & $\checkmark$ & ${ }^{95} \mathrm{Nb}$ & $6.9 \mathrm{E}-3$ & $1.4 \mathrm{E}-2$ & 4.9E-2 & $9.5 \mathrm{E}-2$ & $5.0 \mathrm{E}-3$ \\
\hline \multirow[t]{3}{*}{$\checkmark$} & $\checkmark$ & $\checkmark$ & $\checkmark$ & ${ }^{134} \mathrm{Cs}$ & $2.1 \mathrm{E}-3$ & $4.3 \mathrm{E}-3$ & $1.5 \mathrm{E}-2$ & $3.0 \mathrm{E}-2$ & $9.8 \mathrm{E}-2$ \\
\hline & $\checkmark$ & $\checkmark$ & $\checkmark$ & ${ }^{103} \mathrm{Ru}$ & $7.8 \mathrm{E}-3$ & $1.6 \mathrm{E}-2$ & $5.1 \mathrm{E}-2$ & 7.4E-2 & $8.5 \mathrm{E}-5$ \\
\hline & $\sqrt{ }$ & & $\checkmark$ & $103 \mathrm{~m} R h$ & $7.8 \mathrm{E}-3$ & $1.6 \mathrm{E}-2$ & $5.1 \mathrm{E}-2$ & $7.3 \mathrm{E}-2$ & $8.4 \mathrm{E}-5$ \\
\hline
\end{tabular}




\begin{tabular}{|c|c|c|c|c|c|c|c|c|c|}
\hline \multirow[b]{2}{*}{ 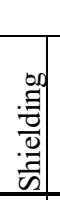 } & \multirow[b]{2}{*}{ 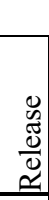 } & \multirow[b]{2}{*}{ 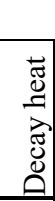 } & \multirow[b]{2}{*}{$\begin{array}{l}.3 \\
.3 \\
.0 \\
\end{array}$} & \multirow[b]{2}{*}{$\begin{array}{l}0 \\
0 \\
0 \\
0 \\
0 \\
0\end{array}$} & \multicolumn{5}{|c|}{ Fraction of activity from isotope } \\
\hline & & & & & $0 \mathrm{~s}$ & $30 \mathrm{~m}$ & $5 \mathrm{~d}$ & $25 \mathrm{~d}$ & $500 \mathrm{~d}$ \\
\hline & $\checkmark$ & $\checkmark$ & $\checkmark$ & ${ }^{95} \mathrm{Zr}$ & $6.8 \mathrm{E}-3$ & $1.4 \mathrm{E}-2$ & $4.6 \mathrm{E}-2$ & $7.6 \mathrm{E}-2$ & $2.3 \mathrm{E}-3$ \\
\hline & $\checkmark$ & & $\checkmark$ & ${ }^{241} \mathrm{Pu}$ & $1.1 \mathrm{E}-3$ & $2.3 \mathrm{E}-3$ & $8.0 \mathrm{E}-3$ & $1.6 \mathrm{E}-2$ & $7.8 \mathrm{E}-2$ \\
\hline & $\checkmark$ & & $\checkmark$ & ${ }^{141} \mathrm{Ce}$ & $7.0 \mathrm{E}-3$ & $1.4 \mathrm{E}-2$ & $4.5 \mathrm{E}-2$ & $6.0 \mathrm{E}-2$ & $1.2 \mathrm{E}-5$ \\
\hline & $\checkmark$ & $\checkmark$ & $\checkmark$ & ${ }^{137} \mathrm{Cs}$ & $1.0 \mathrm{E}-3$ & $2.1 \mathrm{E}-3$ & $7.3 \mathrm{E}-3$ & $1.5 \mathrm{E}-2$ & $7.3 \mathrm{E}-2$ \\
\hline \multirow[t]{5}{*}{$\checkmark$} & $\checkmark$ & $\sqrt{ }$ & $\checkmark$ & ${ }^{137 m} \mathrm{Ba}$ & 9.7E-4 & $2.0 \mathrm{E}-3$ & $6.9 \mathrm{E}-3$ & $1.4 \mathrm{E}-2$ & 7.0E-2 \\
\hline & $\checkmark$ & $\checkmark$ & $\checkmark$ & ${ }^{91} \mathrm{Y}$ & $4.5 \mathrm{E}-3$ & $9.2 \mathrm{E}-3$ & $3.0 \mathrm{E}-2$ & 4.9E-2 & $9.0 \mathrm{E}-4$ \\
\hline & $\checkmark$ & $\checkmark$ & $\checkmark$ & ${ }^{140} \mathrm{La}$ & 7.9E-3 & $1.6 \mathrm{E}-2$ & $4.6 \mathrm{E}-2$ & $3.2 \mathrm{E}-2$ & $1.0 \mathrm{E}-12$ \\
\hline & $\checkmark$ & & $\checkmark$ & ${ }^{147} \mathrm{Pm}$ & $9.3 \mathrm{E}-4$ & $1.9 \mathrm{E}-3$ & $6.7 \mathrm{E}-3$ & $1.4 \mathrm{E}-2$ & $5.0 \mathrm{E}-2$ \\
\hline & $\checkmark$ & & $\checkmark$ & ${ }^{140} \mathrm{Ba}$ & $7.5 \mathrm{E}-3$ & $1.5 \mathrm{E}-2$ & 4.1E-2 & $2.8 \mathrm{E}-2$ & $8.7 \mathrm{E}-13$ \\
\hline \multirow[t]{36}{*}{$\checkmark$} & $\checkmark$ & $\checkmark$ & & ${ }^{90} \mathrm{Y}$ & $7.2 \mathrm{E}-4$ & $1.5 \mathrm{E}-3$ & $5.0 \mathrm{E}-3$ & $1.0 \mathrm{E}-2$ & $5.0 \mathrm{E}-2$ \\
\hline & $\checkmark$ & $\checkmark$ & $\checkmark$ & ${ }^{90} \mathrm{Sr}$ & $6.9 \mathrm{E}-4$ & $1.4 \mathrm{E}-3$ & 4.9E-3 & $1.0 \mathrm{E}-2$ & $5.0 \mathrm{E}-2$ \\
\hline & $\checkmark$ & & & ${ }^{143} \mathrm{Pr}$ & $6.4 \mathrm{E}-3$ & $1.3 \mathrm{E}-2$ & 3.9E-2 & $2.9 \mathrm{E}-2$ & 4.3E-12 \\
\hline & $\checkmark$ & & $\checkmark$ & ${ }^{133} \mathrm{Xe}$ & 8.7E-3 & $1.8 \mathrm{E}-2$ & $3.9 \mathrm{E}-2$ & $5.7 \mathrm{E}-3$ & $0.0 \mathrm{E}+0$ \\
\hline & $\checkmark$ & $\checkmark$ & & ${ }^{89} \mathrm{Sr}$ & $3.4 \mathrm{E}-3$ & $6.8 \mathrm{E}-3$ & $2.2 \mathrm{E}-2$ & $3.5 \mathrm{E}-2$ & $2.6 \mathrm{E}-4$ \\
\hline & $\checkmark$ & & & ${ }^{131} \mathrm{I}$ & $4.5 \mathrm{E}-3$ & $9.2 \mathrm{E}-3$ & $2.2 \mathrm{E}-2$ & $8.0 \mathrm{E}-3$ & $6.2 \mathrm{E}-20$ \\
\hline & $\checkmark$ & & $\checkmark$ & ${ }^{99} \mathrm{Mo}$ & $8.2 \mathrm{E}-3$ & $1.7 \mathrm{E}-2$ & $1.7 \mathrm{E}-2$ & $2.2 \mathrm{E}-4$ & $0.0 \mathrm{E}+0$ \\
\hline & $\checkmark$ & & & ${ }^{99 \mathrm{~m}} \mathrm{Tc}$ & $7.3 \mathrm{E}-3$ & $1.5 \mathrm{E}-2$ & $1.6 \mathrm{E}-2$ & $2.1 \mathrm{E}-4$ & $0.0 \mathrm{E}+0$ \\
\hline & $\checkmark$ & & & ${ }^{132} \mathrm{I}$ & $6.6 \mathrm{E}-3$ & $1.3 \mathrm{E}-2$ & $1.6 \mathrm{E}-2$ & $4.3 \mathrm{E}-4$ & $0.0 \mathrm{E}+0$ \\
\hline & $\checkmark$ & & & ${ }^{132} \mathrm{Te}$ & $6.3 \mathrm{E}-3$ & $1.3 \mathrm{E}-2$ & $1.5 \mathrm{E}-2$ & $4.1 \mathrm{E}-4$ & $0.0 \mathrm{E}+0$ \\
\hline & $\checkmark$ & & $\checkmark$ & ${ }^{133} \mathrm{I}$ & $9.0 \mathrm{E}-3$ & $1.8 \mathrm{E}-2$ & $1.2 \mathrm{E}-3$ & $2.8 \mathrm{E}-10$ & $0.0 \mathrm{E}+0$ \\
\hline & $\checkmark$ & & & ${ }^{147} \mathrm{Nd}$ & $2.9 \mathrm{E}-3$ & $5.8 \mathrm{E}-3$ & $1.5 \mathrm{E}-2$ & $8.6 \mathrm{E}-3$ & 4.2E-15 \\
\hline & $\checkmark$ & & $\checkmark$ & ${ }^{134} \mathrm{I}$ & $1.0 \mathrm{E}-2$ & $1.8 \mathrm{E}-2$ & $0.0 \mathrm{E}+0$ & $0.0 \mathrm{E}+0$ & $0.0 \mathrm{E}+0$ \\
\hline & $\checkmark$ & $\checkmark$ & & ${ }^{156} \mathrm{Eu}$ & $2.3 \mathrm{E}-3$ & $4.6 \mathrm{E}-3$ & 1.3E-2 & $1.1 \mathrm{E}-2$ & $2.1 \mathrm{E}-11$ \\
\hline & $\checkmark$ & & $\checkmark$ & ${ }^{135} \mathrm{I}$ & 8.7E-3 & $1.7 \mathrm{E}-2$ & $2.0 \mathrm{E}-7$ & $0.0 \mathrm{E}+0$ & $0.0 \mathrm{E}+0$ \\
\hline & $\checkmark$ & & & ${ }^{97} \mathrm{Nb}$ & 7.3E-3 & $1.5 \mathrm{E}-2$ & $3.6 \mathrm{E}-4$ & $1.9 \mathrm{E}-12$ & $0.0 \mathrm{E}+0$ \\
\hline & $\checkmark$ & & & ${ }^{97} \mathrm{Zr}$ & 7.3E-3 & $1.4 \mathrm{E}-2$ & $3.6 \mathrm{E}-4$ & $1.7 \mathrm{E}-12$ & $0.0 \mathrm{E}+0$ \\
\hline & $\checkmark$ & & & ${ }^{141} \mathrm{La}$ & $7.0 \mathrm{E}-3$ & $1.4 \mathrm{E}-2$ & 3.3E-11 & $0.0 \mathrm{E}+0$ & $0.0 \mathrm{E}+0$ \\
\hline & $\checkmark$ & & & ${ }^{139} \mathrm{Ba}$ & $7.8 \mathrm{E}-3$ & $1.4 \mathrm{E}-2$ & $0.0 \mathrm{E}+0$ & $0.0 \mathrm{E}+0$ & $0.0 \mathrm{E}+0$ \\
\hline & $\checkmark$ & & & ${ }^{97 \mathrm{~m}} \mathrm{Nb}$ & $6.9 \mathrm{E}-3$ & $1.4 \mathrm{E}-2$ & $3.4 \mathrm{E}-4$ & $1.7 \mathrm{E}-12$ & $0.0 \mathrm{E}+0$ \\
\hline & $\checkmark$ & & & ${ }^{143} \mathrm{Ce}$ & $6.4 \mathrm{E}-3$ & $1.3 \mathrm{E}-2$ & $3.7 \mathrm{E}-3$ & $3.2 \mathrm{E}-7$ & $0.0 \mathrm{E}+0$ \\
\hline & $\checkmark$ & & & ${ }^{138} \mathrm{Cs}$ & $8.2 \mathrm{E}-3$ & $1.2 \mathrm{E}-2$ & $0.0 \mathrm{E}+0$ & $0.0 \mathrm{E}+0$ & $0.0 \mathrm{E}+0$ \\
\hline & $\checkmark$ & & & ${ }^{142} \mathrm{La}$ & $6.7 \mathrm{E}-3$ & $1.2 \mathrm{E}-2$ & $0.0 \mathrm{E}+0$ & $0.0 \mathrm{E}+0$ & $0.0 \mathrm{E}+0$ \\
\hline & $\checkmark$ & & & ${ }^{105} \mathrm{Rh}$ & $5.4 \mathrm{E}-3$ & $1.1 \mathrm{E}-2$ & 4.2E-3 & $7.1 \mathrm{E}-7$ & $0.0 \mathrm{E}+0$ \\
\hline & $\checkmark$ & & & ${ }^{93} \mathrm{Y}$ & $5.8 \mathrm{E}-3$ & $1.1 \mathrm{E}-2$ & $1.2 \mathrm{E}-5$ & $1.5 \mathrm{E}-19$ & $0.0 \mathrm{E}+0$ \\
\hline & $\checkmark$ & & & ${ }^{105} \mathrm{Ru}$ & $5.9 \mathrm{E}-3$ & $1.1 \mathrm{E}-2$ & $3.2 \mathrm{E}-10$ & $0.0 \mathrm{E}+0$ & $0.0 \mathrm{E}+0$ \\
\hline & $\checkmark$ & $\checkmark$ & & ${ }^{238} \mathrm{~Np}$ & $4.6 \mathrm{E}-3$ & $9.4 \mathrm{E}-3$ & $6.4 \mathrm{E}-3$ & $1.9 \mathrm{E}-5$ & $2.9 \mathrm{E}-8$ \\
\hline & $\checkmark$ & $\checkmark$ & & ${ }^{242} \mathrm{Cm}$ & $6.5 \mathrm{E}-4$ & $1.3 \mathrm{E}-3$ & $4.5 \mathrm{E}-3$ & $8.5 \mathrm{E}-3$ & $5.8 \mathrm{E}-3$ \\
\hline & $\checkmark$ & & & ${ }^{92} \mathrm{Y}$ & $4.9 \mathrm{E}-3$ & $1.0 \mathrm{E}-2$ & $9.3 \mathrm{E}-12$ & $0.0 \mathrm{E}+0$ & $0.0 \mathrm{E}+0$ \\
\hline & $\checkmark$ & & & ${ }^{134} \mathrm{Te}$ & $7.6 \mathrm{E}-3$ & $9.5 \mathrm{E}-3$ & $0.0 \mathrm{E}+0$ & $0.0 \mathrm{E}+0$ & $0.0 \mathrm{E}+0$ \\
\hline & $\checkmark$ & & & ${ }^{101} \mathrm{Tc}$ & $7.8 \mathrm{E}-3$ & $9.2 \mathrm{E}-3$ & $0.0 \mathrm{E}+0$ & $0.0 \mathrm{E}+0$ & $0.0 \mathrm{E}+0$ \\
\hline & $\checkmark$ & & & ${ }^{92} \mathrm{Sr}$ & $4.9 \mathrm{E}-3$ & $8.7 \mathrm{E}-3$ & $1.6 \mathrm{E}-15$ & $0.0 \mathrm{E}+0$ & $0.0 \mathrm{E}+0$ \\
\hline & $\checkmark$ & & & ${ }^{91} \mathrm{Sr}$ & $4.4 \mathrm{E}-3$ & $8.7 \mathrm{E}-3$ & $5.6 \mathrm{E}-6$ & $1.1 \mathrm{E}-20$ & $0.0 \mathrm{E}+0$ \\
\hline & $\checkmark$ & & & ${ }^{145} \mathrm{Pr}$ & $4.4 \mathrm{E}-3$ & $8.5 \mathrm{E}-3$ & $2.9 \mathrm{E}-8$ & $0.0 \mathrm{E}+0$ & $0.0 \mathrm{E}+0$ \\
\hline & $\checkmark$ & & & ${ }^{243} \mathrm{Pu}$ & $3.9 \mathrm{E}-3$ & 7.3E-3 & $1.4 \mathrm{E}-9$ & $6.1 \mathrm{E}-13$ & $3.1 \mathrm{E}-12$ \\
\hline & $\checkmark$ & & & ${ }^{153} \mathrm{Sm}$ & $3.0 \mathrm{E}-3$ & $6.0 \mathrm{E}-3$ & $3.5 \mathrm{E}-3$ & $5.6 \mathrm{E}-6$ & $0.0 \mathrm{E}+0$ \\
\hline \multirow[t]{2}{*}{$\checkmark$} & $\checkmark$ & $\checkmark$ & & ${ }^{244} \mathrm{Cm}$ & $9.5 \mathrm{E}-5$ & $1.9 \mathrm{E}-4$ & $6.7 \mathrm{E}-4$ & $1.4 \mathrm{E}-3$ & $6.7 \mathrm{E}-3$ \\
\hline & $\checkmark$ & & & ${ }^{149} \mathrm{Pm}$ & $2.6 \mathrm{E}-3$ & $5.2 \mathrm{E}-3$ & $3.9 \mathrm{E}-3$ & $1.5 \mathrm{E}-5$ & $0.0 \mathrm{E}+0$ \\
\hline
\end{tabular}




\begin{tabular}{|c|c|c|c|c|c|c|c|c|c|}
\hline \multirow[b]{2}{*}{ 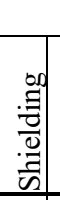 } & \multirow[b]{2}{*}{ 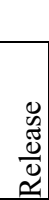 } & \multirow[b]{2}{*}{ 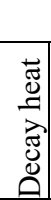 } & \multirow[b]{2}{*}{ 永 } & \multirow[b]{2}{*}{ 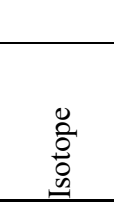 } & \multicolumn{5}{|c|}{ Fraction of activity from isotope } \\
\hline & & & & & $0 \mathrm{~s}$ & $30 \mathrm{~m}$ & $5 \mathrm{~d}$ & $25 \mathrm{~d}$ & $500 \mathrm{~d}$ \\
\hline & $\checkmark$ & & & ${ }^{135} \mathrm{Xe}$ & $2.8 \mathrm{E}-3$ & $6.1 \mathrm{E}-3$ & $1.9 \mathrm{E}-5$ & $6.3 \mathrm{E}-21$ & $0.0 \mathrm{E}+0$ \\
\hline & $\checkmark$ & & & ${ }^{133 \mathrm{~m}} \mathrm{Te}$ & $4.4 \mathrm{E}-3$ & $6.1 \mathrm{E}-3$ & $0.0 \mathrm{E}+0$ & $0.0 \mathrm{E}+0$ & $0.0 \mathrm{E}+0$ \\
\hline & $\checkmark$ & & & ${ }^{131} \mathrm{Te}$ & $3.9 \mathrm{E}-3$ & $6.1 \mathrm{E}-3$ & $1.4 \mathrm{E}-4$ & $1.3 \mathrm{E}-8$ & $0.0 \mathrm{E}+0$ \\
\hline & $\checkmark$ & & & ${ }^{85} \mathrm{Kr}$ & $8.5 \mathrm{E}-5$ & $1.7 \mathrm{E}-4$ & $6.1 \mathrm{E}-4$ & $1.2 \mathrm{E}-3$ & $5.8 \mathrm{E}-3$ \\
\hline$\checkmark$ & $\checkmark$ & $\checkmark$ & & ${ }^{154} \mathrm{Eu}$ & $8.6 \mathrm{E}-5$ & $1.8 \mathrm{E}-4$ & $6.1 \mathrm{E}-4$ & $1.3 \mathrm{E}-3$ & $5.7 \mathrm{E}-3$ \\
\hline$\checkmark$ & $\checkmark$ & $\checkmark$ & & ${ }^{238} \mathrm{Pu}$ & $6.9 \mathrm{E}-5$ & $1.4 \mathrm{E}-4$ & $4.9 \mathrm{E}-4$ & $1.0 \mathrm{E}-3$ & $5.3 \mathrm{E}-3$ \\
\hline & $\checkmark$ & & & $91 \mathrm{~m} Y$ & $2.6 \mathrm{E}-3$ & $5.2 \mathrm{E}-3$ & $3.6 \mathrm{E}-6$ & $7.3 \mathrm{E}-21$ & $0.0 \mathrm{E}+0$ \\
\hline & $\checkmark$ & & & ${ }^{146} \mathrm{Pr}$ & $3.6 \mathrm{E}-3$ & $5.0 \mathrm{E}-3$ & $0.0 \mathrm{E}+0$ & $0.0 \mathrm{E}+0$ & $0.0 \mathrm{E}+0$ \\
\hline & $\checkmark$ & & & ${ }^{88} \mathrm{Rb}$ & $2.5 \mathrm{E}-3$ & $4.8 \mathrm{E}-3$ & $3.7 \mathrm{E}-15$ & $0.0 \mathrm{E}+0$ & $0.0 \mathrm{E}+0$ \\
\hline & $\checkmark$ & & & ${ }^{148} \mathrm{Pm}$ & $1.1 \mathrm{E}-3$ & $2.2 \mathrm{E}-3$ & 4.1E-3 & $7.2 \mathrm{E}-4$ & $1.8 \mathrm{E}-7$ \\
\hline & $\checkmark$ & $\checkmark$ & & ${ }^{104} \mathrm{Tc}$ & $6.8 \mathrm{E}-3$ & $4.7 \mathrm{E}-3$ & $0.0 \mathrm{E}+0$ & $0.0 \mathrm{E}+0$ & $0.0 \mathrm{E}+0$ \\
\hline & $\checkmark$ & & & ${ }^{141} \mathrm{Ba}$ & $7.0 \mathrm{E}-3$ & $4.6 \mathrm{E}-3$ & $0.0 \mathrm{E}+0$ & $0.0 \mathrm{E}+0$ & $0.0 \mathrm{E}+0$ \\
\hline & $\checkmark$ & & & ${ }^{109} \mathrm{Pd}$ & $2.3 \mathrm{E}-3$ & $4.6 \mathrm{E}-3$ & $3.8 \mathrm{E}-5$ & $2.2 \mathrm{E}-15$ & $0.0 \mathrm{E}+0$ \\
\hline & $\checkmark$ & & & ${ }^{94} \mathrm{Y}$ & $6.2 \mathrm{E}-3$ & $4.4 \mathrm{E}-3$ & $0.0 \mathrm{E}+0$ & $0.0 \mathrm{E}+0$ & $0.0 \mathrm{E}+0$ \\
\hline & $\checkmark$ & & & ${ }^{88} \mathrm{Kr}$ & $2.4 \mathrm{E}-3$ & $4.4 \mathrm{E}-3$ & $3.3 \mathrm{E}-15$ & $0.0 \mathrm{E}+0$ & $0.0 \mathrm{E}+0$ \\
\hline & $\checkmark$ & $\checkmark$ & & ${ }^{136} \mathrm{Cs}$ & $6.1 \mathrm{E}-4$ & $1.2 \mathrm{E}-3$ & $3.3 \mathrm{E}-3$ & $2.4 \mathrm{E}-3$ & $1.7 \mathrm{E}-13$ \\
\hline & $\checkmark$ & & & ${ }^{125} \mathrm{Sb}$ & $7.5 \mathrm{E}-5$ & $1.5 \mathrm{E}-4$ & $5.3 \mathrm{E}-4$ & $1.1 \mathrm{E}-3$ & $4.0 \mathrm{E}-3$ \\
\hline & $\checkmark$ & & & ${ }^{101} \mathrm{Mo}$ & $7.8 \mathrm{E}-3$ & $3.9 \mathrm{E}-3$ & $0.0 \mathrm{E}+0$ & $0.0 \mathrm{E}+0$ & $0.0 \mathrm{E}+0$ \\
\hline & $\checkmark$ & & & ${ }^{138} \mathrm{Xe}$ & $7.5 \mathrm{E}-3$ & $3.5 \mathrm{E}-3$ & $0.0 \mathrm{E}+0$ & $0.0 \mathrm{E}+0$ & $0.0 \mathrm{E}+0$ \\
\hline & $\checkmark$ & & & ${ }^{107} \mathrm{Rh}$ & $3.5 \mathrm{E}-3$ & $3.3 \mathrm{E}-3$ & $0.0 \mathrm{E}+0$ & $0.0 \mathrm{E}+0$ & $0.0 \mathrm{E}+0$ \\
\hline & $\checkmark$ & & & ${ }^{105 \mathrm{~m} R h}$ & $1.7 \mathrm{E}-3$ & $3.2 \mathrm{E}-3$ & $9.0 \mathrm{E}-11$ & $0.0 \mathrm{E}+0$ & $0.0 \mathrm{E}+0$ \\
\hline & $\checkmark$ & & & ${ }^{135 \mathrm{~m}} \mathrm{Xe}$ & $2.0 \mathrm{E}-3$ & $3.1 \mathrm{E}-3$ & $3.4 \mathrm{E}-8$ & $0.0 \mathrm{E}+0$ & $0.0 \mathrm{E}+0$ \\
\hline & $\checkmark$ & & & ${ }^{143} \mathrm{La}$ & $6.4 \mathrm{E}-3$ & $3.0 \mathrm{E}-3$ & $0.0 \mathrm{E}+0$ & $0.0 \mathrm{E}+0$ & $0.0 \mathrm{E}+0$ \\
\hline & $\checkmark$ & & & ${ }^{149} \mathrm{Nd}$ & $1.8 \mathrm{E}-3$ & $3.0 \mathrm{E}-3$ & $1.6 \mathrm{E}-23$ & $0.0 \mathrm{E}+0$ & $0.0 \mathrm{E}+0$ \\
\hline & $\checkmark$ & & & ${ }^{155} \mathrm{Eu}$ & 4.7E-5 & $9.6 \mathrm{E}-5$ & $3.3 \mathrm{E}-4$ & $6.8 \mathrm{E}-4$ & $2.9 \mathrm{E}-3$ \\
\hline & $\checkmark$ & & & ${ }^{129} \mathrm{Te}$ & $1.3 \mathrm{E}-3$ & $2.6 \mathrm{E}-3$ & $8.0 \mathrm{E}-4$ & $1.1 \mathrm{E}-3$ & $3.1 \mathrm{E}-7$ \\
\hline & $\checkmark$ & & & ${ }^{131} \mathrm{Sb}$ & $3.5 \mathrm{E}-3$ & $2.9 \mathrm{E}-3$ & $0.0 \mathrm{E}+0$ & $0.0 \mathrm{E}+0$ & $0.0 \mathrm{E}+0$ \\
\hline & $\checkmark$ & & & ${ }^{133} \mathrm{Te}$ & $4.6 \mathrm{E}-3$ & $2.9 \mathrm{E}-3$ & $0.0 \mathrm{E}+0$ & $0.0 \mathrm{E}+0$ & $0.0 \mathrm{E}+0$ \\
\hline & $\checkmark$ & & & ${ }^{87} \mathrm{Kr}$ & $1.8 \mathrm{E}-3$ & $2.9 \mathrm{E}-3$ & $0.0 \mathrm{E}+0$ & $0.0 \mathrm{E}+0$ & $0.0 \mathrm{E}+0$ \\
\hline & $\checkmark$ & & & ${ }^{129} \mathrm{Sb}$ & $1.4 \mathrm{E}-3$ & $2.6 \mathrm{E}-3$ & $6.1 \mathrm{E}-11$ & $0.0 \mathrm{E}+0$ & $0.0 \mathrm{E}+0$ \\
\hline & $\checkmark$ & & & ${ }^{148 \mathrm{~m} P m}$ & $2.2 \mathrm{E}-4$ & 4.4E-4 & $1.4 \mathrm{E}-3$ & $2.1 \mathrm{E}-3$ & $3.6 \mathrm{E}-6$ \\
\hline & $\checkmark$ & & & ${ }^{102} \mathrm{Tc}$ & $7.6 \mathrm{E}-3$ & $2.5 \mathrm{E}-3$ & $0.0 \mathrm{E}+0$ & $0.0 \mathrm{E}+0$ & $0.0 \mathrm{E}+0$ \\
\hline & $\checkmark$ & & & ${ }^{102} \mathrm{Mo}$ & $7.6 \mathrm{E}-3$ & $2.5 \mathrm{E}-3$ & $0.0 \mathrm{E}+0$ & $0.0 \mathrm{E}+0$ & $0.0 \mathrm{E}+0$ \\
\hline & $\checkmark$ & & & ${ }^{129 \mathrm{~m}} \mathrm{Te}$ & $2.0 \mathrm{E}-4$ & $4.0 \mathrm{E}-4$ & $1.3 \mathrm{E}-3$ & $1.7 \mathrm{E}-3$ & $4.8 \mathrm{E}-7$ \\
\hline & $\checkmark$ & & & ${ }^{89} \mathrm{Rb}$ & $3.3 \mathrm{E}-3$ & $2.1 \mathrm{E}-3$ & $0.0 \mathrm{E}+0$ & $0.0 \mathrm{E}+0$ & $0.0 \mathrm{E}+0$ \\
\hline & $\checkmark$ & & & ${ }^{244 \mathrm{~m}} \mathrm{Am}$ & $2.2 \mathrm{E}-3$ & $2.0 \mathrm{E}-3$ & $0.0 \mathrm{E}+0$ & $0.0 \mathrm{E}+0$ & $0.0 \mathrm{E}+0$ \\
\hline & $\checkmark$ & & & ${ }^{151} \mathrm{Pm}$ & $9.6 \mathrm{E}-4$ & $1.9 \mathrm{E}-3$ & $3.7 \mathrm{E}-4$ & $6.2 \mathrm{E}-9$ & $0.0 \mathrm{E}+0$ \\
\hline & $\checkmark$ & & & ${ }^{131 \mathrm{~m} T e}$ & $9.1 \mathrm{E}-4$ & $1.8 \mathrm{E}-3$ & $5.3 \mathrm{E}-4$ & $4.9 \mathrm{E}-8$ & $0.0 \mathrm{E}+0$ \\
\hline & $\checkmark$ & & & ${ }^{127} \mathrm{Te}$ & $4.3 \mathrm{E}-4$ & $8.8 \mathrm{E}-4$ & $1.6 \mathrm{E}-3$ & $5.9 \mathrm{E}-4$ & $1.3 \mathrm{E}-4$ \\
\hline & $\checkmark$ & & & ${ }^{242} \mathrm{Am}$ & $9.4 \mathrm{E}-4$ & $1.9 \mathrm{E}-3$ & $3.8 \mathrm{E}-5$ & $1.3 \mathrm{E}-6$ & $6.3 \mathrm{E}-6$ \\
\hline & $\checkmark$ & & & ${ }^{85 \mathrm{~m} K r}$ & $9.8 \mathrm{E}-4$ & $1.9 \mathrm{E}-3$ & $6.1 \mathrm{E}-11$ & $0.0 \mathrm{E}+0$ & $0.0 \mathrm{E}+0$ \\
\hline & $\checkmark$ & & & ${ }^{142} \mathrm{Ba}$ & $6.5 \mathrm{E}-3$ & $1.9 \mathrm{E}-3$ & $0.0 \mathrm{E}+0$ & $0.0 \mathrm{E}+0$ & $0.0 \mathrm{E}+0$ \\
\hline & $\checkmark$ & & & ${ }^{95} \mathrm{Y}$ & $6.6 \mathrm{E}-3$ & $1.8 \mathrm{E}-3$ & $0.0 \mathrm{E}+0$ & $0.0 \mathrm{E}+0$ & $0.0 \mathrm{E}+0$ \\
\hline & $\checkmark$ & & & ${ }^{139} \mathrm{Cs}$ & $7.6 \mathrm{E}-3$ & $1.7 \mathrm{E}-3$ & $0.0 \mathrm{E}+0$ & $0.0 \mathrm{E}+0$ & $0.0 \mathrm{E}+0$ \\
\hline & $\checkmark$ & & & ${ }^{127} \mathrm{Sb}$ & 4.7E-4 & $9.5 \mathrm{E}-4$ & $1.4 \mathrm{E}-3$ & 7.7E-5 & $0.0 \mathrm{E}+0$ \\
\hline & $\checkmark$ & & & ${ }^{146} \mathrm{Ce}$ & $3.6 \mathrm{E}-3$ & $1.6 \mathrm{E}-3$ & $0.0 \mathrm{E}+0$ & $0.0 \mathrm{E}+0$ & $0.0 \mathrm{E}+0$ \\
\hline & $\checkmark$ & & & ${ }^{144 \mathrm{~m}} \mathrm{Pr}$ & $8.1 \mathrm{E}-5$ & $1.2 \mathrm{E}-4$ & $4.0 \mathrm{E}-4$ & $7.8 \mathrm{E}-4$ & $1.2 \mathrm{E}-3$ \\
\hline
\end{tabular}




\begin{tabular}{|c|c|c|c|c|c|c|c|c|c|}
\hline \multirow[b]{2}{*}{ 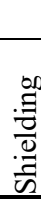 } & \multirow[b]{2}{*}{$\begin{array}{l}0 \\
\tilde{J} \\
\underline{0} \\
\underline{\underline{U}}\end{array}$} & \multirow[b]{2}{*}{ 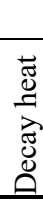 } & \multirow[b]{2}{*}{$\begin{array}{l}3 \\
0 \\
0 \\
0\end{array}$} & \multirow[b]{2}{*}{$\begin{array}{l}0 \\
0 \\
0 \\
0 \\
0 \\
0\end{array}$} & \multicolumn{5}{|c|}{ Fraction of activity from isotope } \\
\hline & & & & & $0 \mathrm{~s}$ & $30 \mathrm{~m}$ & $5 \mathrm{~d}$ & $25 \mathrm{~d}$ & $500 \mathrm{~d}$ \\
\hline & $\checkmark$ & & & ${ }^{130} \mathrm{Sb}$ & $1.2 \mathrm{E}-3$ & $1.5 \mathrm{E}-3$ & $0.0 \mathrm{E}+0$ & $0.0 \mathrm{E}+0$ & $0.0 \mathrm{E}+0$ \\
\hline & $\checkmark$ & & & ${ }^{147} \mathrm{Pr}$ & $2.8 \mathrm{E}-3$ & $1.3 \mathrm{E}-3$ & $0.0 \mathrm{E}+0$ & $0.0 \mathrm{E}+0$ & $0.0 \mathrm{E}+0$ \\
\hline & $\checkmark$ & & & ${ }^{128 \mathrm{~m} S b}$ & $6.9 \mathrm{E}-4$ & $1.1 \mathrm{E}-3$ & $0.0 \mathrm{E}+0$ & $0.0 \mathrm{E}+0$ & $0.0 \mathrm{E}+0$ \\
\hline & $\checkmark$ & & & ${ }^{142} \mathrm{Pr}$ & $5.5 \mathrm{E}-4$ & $1.1 \mathrm{E}-3$ & $5.0 \mathrm{E}-5$ & 2.9E-12 & $0.0 \mathrm{E}+0$ \\
\hline & $\checkmark$ & & & $95 \mathrm{~m} \mathrm{Nb}$ & $7.4 \mathrm{E}-5$ & $1.5 \mathrm{E}-4$ & $5.2 \mathrm{E}-4$ & $8.7 \mathrm{E}-4$ & $2.6 \mathrm{E}-5$ \\
\hline & $\sqrt{ }$ & & & ${ }^{125 \mathrm{~m} T e}$ & $1.7 \mathrm{E}-5$ & $3.4 \mathrm{E}-5$ & $1.2 \mathrm{E}-4$ & $2.5 \mathrm{E}-4$ & $9.7 \mathrm{E}-4$ \\
\hline
\end{tabular}


Table A.4. Fractional contributions of istopes to total activity of $80 \mathrm{GWd} / \mathrm{MTU} 8 \mathrm{wt} \%$

\begin{tabular}{|r|r|r|r|r|r|}
\cline { 2 - 6 } \multicolumn{1}{l|}{} & $\mathbf{0 ~ s}$ & $\mathbf{3 0 ~ m}$ & $\mathbf{5 ~ d}$ & $\mathbf{2 5} \mathbf{~ d}$ & $\mathbf{5 0 0} \mathbf{~ d}$ \\
\hline Total calculated & & & & & \\
(MCi/MTU) & 237 & 116 & 33.5 & 16.6 & 3.22 \\
\hline Total listed (MCi/MTU) & 127 & 103 & 32.3 & 16.5 & 3.20 \\
\hline
\end{tabular}

\begin{tabular}{|c|c|c|c|c|c|c|c|c|c|}
\hline \multirow[b]{2}{*}{ 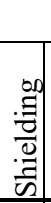 } & \multirow[b]{2}{*}{ 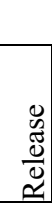 } & \multirow[b]{2}{*}{ 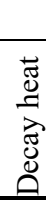 } & \multirow[b]{2}{*}{ 总 } & \multirow[b]{2}{*}{ 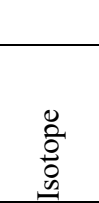 } & \multicolumn{5}{|c|}{ Fraction of activity from isotope } \\
\hline & & & & & $0 \mathrm{~s}$ & $30 \mathrm{~m}$ & $5 \mathrm{~d}$ & $25 \mathrm{~d}$ & $500 \mathrm{~d}$ \\
\hline & $\sqrt{ }$ & $\checkmark$ & $\sqrt{ }$ & ${ }^{239} \mathrm{~Np}$ & $8.7 \mathrm{E}-02$ & $1.8 \mathrm{E}-01$ & $1.4 \mathrm{E}-01$ & $8.0 \mathrm{E}-04$ & $1.8 \mathrm{E}-05$ \\
\hline \multirow[t]{4}{*}{$\sqrt{ }$} & $\checkmark$ & $\checkmark$ & $\checkmark$ & ${ }^{144} \mathrm{Pr}$ & $6.3 \mathrm{E}-03$ & $1.3 \mathrm{E}-02$ & $4.4 \mathrm{E}-02$ & $8.4 \mathrm{E}-02$ & $1.4 \mathrm{E}-01$ \\
\hline & $\checkmark$ & & $\checkmark$ & ${ }^{144} \mathrm{Ce}$ & $6.3 \mathrm{E}-03$ & $1.3 \mathrm{E}-02$ & $4.4 \mathrm{E}-02$ & $8.4 \mathrm{E}-02$ & $1.4 \mathrm{E}-01$ \\
\hline & $\checkmark$ & $\checkmark$ & $\checkmark$ & ${ }^{95} \mathrm{Nb}$ & 7.3E-03 & $1.5 \mathrm{E}-02$ & $5.2 \mathrm{E}-02$ & $9.8 \mathrm{E}-02$ & $5.3 \mathrm{E}-03$ \\
\hline & $\checkmark$ & & $\checkmark$ & ${ }^{106} \mathrm{Ru}$ & $3.4 \mathrm{E}-03$ & $6.9 \mathrm{E}-03$ & $2.4 \mathrm{E}-02$ & 4.6E-02 & $9.8 \mathrm{E}-02$ \\
\hline$\checkmark$ & $\checkmark$ & $\checkmark$ & $\checkmark$ & ${ }^{106} \mathrm{Ru}$ & $3.7 \mathrm{E}-03$ & $6.9 \mathrm{E}-03$ & $2.4 \mathrm{E}-02$ & $4.6 \mathrm{E}-02$ & $9.8 \mathrm{E}-02$ \\
\hline \multirow[t]{7}{*}{$\checkmark$} & $\checkmark$ & $\checkmark$ & $\checkmark$ & ${ }^{134} \mathrm{Cs}$ & $2.0 \mathrm{E}-03$ & $4.1 \mathrm{E}-03$ & $1.4 \mathrm{E}-02$ & $2.8 \mathrm{E}-02$ & $9.2 \mathrm{E}-02$ \\
\hline & $\checkmark$ & $\checkmark$ & $\checkmark$ & ${ }^{95} \mathrm{Zr}$ & $7.3 \mathrm{E}-03$ & $1.5 \mathrm{E}-02$ & $4.9 \mathrm{E}-02$ & $7.9 \mathrm{E}-02$ & $2.4 \mathrm{E}-03$ \\
\hline & $\checkmark$ & $\checkmark$ & $\checkmark$ & ${ }^{103} \mathrm{Ru}$ & $7.5 \mathrm{E}-03$ & $1.5 \mathrm{E}-02$ & $4.9 \mathrm{E}-02$ & $6.9 \mathrm{E}-02$ & $8.1 \mathrm{E}-05$ \\
\hline & $\sqrt{ }$ & & $\checkmark$ & ${ }^{103 \mathrm{~m} R h}$ & $7.4 \mathrm{E}-03$ & $1.5 \mathrm{E}-02$ & $4.8 \mathrm{E}-02$ & $6.8 \mathrm{E}-02$ & $8.0 \mathrm{E}-05$ \\
\hline & $\checkmark$ & & $\checkmark$ & ${ }^{241} \mathrm{Pu}$ & $1.2 \mathrm{E}-03$ & $2.4 \mathrm{E}-03$ & $8.3 \mathrm{E}-03$ & $1.7 \mathrm{E}-02$ & $8.1 \mathrm{E}-02$ \\
\hline & $\checkmark$ & & $\checkmark$ & ${ }^{141} \mathrm{Ce}$ & $7.3 \mathrm{E}-03$ & $1.5 \mathrm{E}-02$ & $4.7 \mathrm{E}-02$ & $6.1 \mathrm{E}-02$ & $1.3 \mathrm{E}-05$ \\
\hline & $\checkmark$ & $\checkmark$ & $\checkmark$ & ${ }^{137} \mathrm{Cs}$ & $1.0 \mathrm{E}-03$ & $2.1 \mathrm{E}-03$ & 7.4E-03 & $1.5 \mathrm{E}-02$ & 7.4E-02 \\
\hline \multirow[t]{4}{*}{$\checkmark$} & $\checkmark$ & $\checkmark$ & $\checkmark$ & ${ }^{137 m} \mathrm{Ba}$ & $9.9 \mathrm{E}-04$ & $2.0 \mathrm{E}-03$ & $7.0 \mathrm{E}-03$ & $1.4 \mathrm{E}-02$ & $7.1 \mathrm{E}-02$ \\
\hline & $\checkmark$ & $\checkmark$ & $\checkmark$ & ${ }^{91} \mathrm{Y}$ & $5.1 \mathrm{E}-03$ & $1.0 \mathrm{E}-02$ & $3.4 \mathrm{E}-02$ & $5.4 \mathrm{E}-02$ & $1.0 \mathrm{E}-03$ \\
\hline & $\checkmark$ & $\checkmark$ & $\checkmark$ & ${ }^{140} \mathrm{La}$ & $8.1 \mathrm{E}-03$ & $1.7 \mathrm{E}-02$ & $4.8 \mathrm{E}-02$ & $3.3 \mathrm{E}-02$ & $1.0 \mathrm{E}-12$ \\
\hline & $\checkmark$ & & $\checkmark$ & ${ }^{147} \mathrm{Pm}$ & $1.0 \mathrm{E}-03$ & $2.2 \mathrm{E}-03$ & $7.5 \mathrm{E}-03$ & $1.5 \mathrm{E}-02$ & $5.6 \mathrm{E}-02$ \\
\hline \multirow[t]{24}{*}{$\checkmark$} & $\checkmark$ & $\checkmark$ & & ${ }^{90} \mathrm{Y}$ & $7.8 \mathrm{E}-04$ & $1.6 \mathrm{E}-03$ & $5.4 \mathrm{E}-03$ & $1.1 \mathrm{E}-02$ & $5.4 \mathrm{E}-02$ \\
\hline & $\checkmark$ & $\checkmark$ & $\checkmark$ & ${ }^{90} \mathrm{Sr}$ & $7.5 \mathrm{E}-04$ & $1.5 \mathrm{E}-03$ & $5.3 \mathrm{E}-03$ & $1.1 \mathrm{E}-02$ & $5.4 \mathrm{E}-02$ \\
\hline & $\checkmark$ & & $\checkmark$ & ${ }^{140} \mathrm{Ba}$ & $7.8 \mathrm{E}-03$ & $1.6 \mathrm{E}-02$ & $4.2 \mathrm{E}-02$ & $2.8 \mathrm{E}-02$ & $9.0 \mathrm{E}-13$ \\
\hline & $\checkmark$ & & & ${ }^{143} \mathrm{Pr}$ & $6.8 \mathrm{E}-03$ & $1.4 \mathrm{E}-02$ & $4.1 \mathrm{E}-02$ & $3.0 \mathrm{E}-02$ & $4.5 \mathrm{E}-12$ \\
\hline & $\checkmark$ & $\checkmark$ & & ${ }^{89} \mathrm{Sr}$ & $3.9 \mathrm{E}-03$ & $8.0 \mathrm{E}-03$ & $2.6 \mathrm{E}-02$ & $3.9 \mathrm{E}-02$ & $3.0 \mathrm{E}-04$ \\
\hline & $\checkmark$ & & $\checkmark$ & ${ }^{133} \mathrm{Xe}$ & $8.9 \mathrm{E}-03$ & $1.8 \mathrm{E}-02$ & $3.9 \mathrm{E}-02$ & $5.7 \mathrm{E}-03$ & $0.0 \mathrm{E}+0$ \\
\hline & $\checkmark$ & & & ${ }^{131} \mathrm{I}$ & $4.6 \mathrm{E}-03$ & $9.4 \mathrm{E}-03$ & $2.2 \mathrm{E}-02$ & $7.8 \mathrm{E}-03$ & $6.2 \mathrm{E}-20$ \\
\hline & $\checkmark$ & & $\checkmark$ & ${ }^{99} \mathrm{Mo}$ & $8.4 \mathrm{E}-03$ & $1.7 \mathrm{E}-02$ & $1.7 \mathrm{E}-02$ & $2.2 \mathrm{E}-04$ & $0.0 \mathrm{E}+0$ \\
\hline & $\checkmark$ & & & ${ }^{99 \mathrm{~m}} \mathrm{Tc}$ & 7.4E-03 & $1.5 \mathrm{E}-02$ & $1.6 \mathrm{E}-02$ & $2.1 \mathrm{E}-04$ & $0.0 \mathrm{E}+0$ \\
\hline & $\checkmark$ & & & ${ }^{132} \mathrm{I}$ & $6.6 \mathrm{E}-03$ & $1.4 \mathrm{E}-02$ & $1.6 \mathrm{E}-02$ & $4.2 \mathrm{E}-04$ & $0.0 \mathrm{E}+0$ \\
\hline & $\checkmark$ & & & ${ }^{132} \mathrm{Te}$ & $6.4 \mathrm{E}-03$ & $1.3 \mathrm{E}-02$ & $1.5 \mathrm{E}-02$ & 4.1E-04 & $0.0 \mathrm{E}+0$ \\
\hline & $\checkmark$ & & $\checkmark$ & ${ }^{133} \mathrm{I}$ & $9.2 \mathrm{E}-03$ & $1.9 \mathrm{E}-02$ & $1.2 \mathrm{E}-03$ & $2.8 \mathrm{E}-10$ & $0.0 \mathrm{E}+0$ \\
\hline & $\checkmark$ & & & ${ }^{147} \mathrm{Nd}$ & $3.0 \mathrm{E}-03$ & $6.1 \mathrm{E}-03$ & $1.5 \mathrm{E}-02$ & $8.7 \mathrm{E}-03$ & $4.3 \mathrm{E}-15$ \\
\hline & $\checkmark$ & & $\checkmark$ & ${ }^{134} \mathrm{I}$ & $1.0 \mathrm{E}-02$ & $1.9 \mathrm{E}-02$ & $0.0 \mathrm{E}+0$ & $0.0 \mathrm{E}+0$ & $0.0 \mathrm{E}+0$ \\
\hline & $\sqrt{ }$ & & $\checkmark$ & ${ }^{135} \mathrm{I}$ & $8.8 \mathrm{E}-03$ & $1.7 \mathrm{E}-02$ & $2.0 \mathrm{E}-07$ & $0.0 \mathrm{E}+0$ & $0.0 \mathrm{E}+0$ \\
\hline & $\checkmark$ & & $\checkmark$ & ${ }^{97} \mathrm{Nb}$ & 7.6E-03 & $1.6 \mathrm{E}-02$ & 3.7E-04 & $1.9 \mathrm{E}-12$ & $0.0 \mathrm{E}+0$ \\
\hline & $\checkmark$ & & & ${ }^{97} \mathrm{Zr}$ & $7.6 \mathrm{E}-03$ & $1.5 \mathrm{E}-02$ & $3.7 \mathrm{E}-04$ & $1.8 \mathrm{E}-12$ & $0.0 \mathrm{E}+0$ \\
\hline & $\checkmark$ & & & ${ }^{141} \mathrm{La}$ & 7.3E-03 & $1.5 \mathrm{E}-02$ & $3.4 \mathrm{E}-11$ & $0.0 \mathrm{E}+0$ & $0.0 \mathrm{E}+0$ \\
\hline & $\checkmark$ & & & ${ }^{97 \mathrm{~m}} \mathrm{Nb}$ & 7.2E-03 & $1.4 \mathrm{E}-02$ & $3.6 \mathrm{E}-04$ & $1.7 \mathrm{E}-12$ & $0.0 \mathrm{E}+0$ \\
\hline & $\sqrt{ }$ & $\checkmark$ & & ${ }^{156} \mathrm{Eu}$ & $1.9 \mathrm{E}-03$ & $3.9 \mathrm{E}-03$ & $1.1 \mathrm{E}-02$ & $8.7 \mathrm{E}-03$ & $1.7 \mathrm{E}-11$ \\
\hline & $\checkmark$ & & & ${ }^{139} \mathrm{Ba}$ & $8.1 \mathrm{E}-03$ & $1.4 \mathrm{E}-02$ & $0.0 \mathrm{E}+0$ & $0.0 \mathrm{E}+0$ & $0.0 \mathrm{E}+0$ \\
\hline & $\checkmark$ & & & ${ }^{143} \mathrm{Ce}$ & $6.8 \mathrm{E}-03$ & $1.4 \mathrm{E}-02$ & $3.9 \mathrm{E}-03$ & $3.3 \mathrm{E}-07$ & $0.0 \mathrm{E}+0$ \\
\hline & $\checkmark$ & & & ${ }^{138} \mathrm{Cs}$ & $8.5 \mathrm{E}-03$ & $1.3 \mathrm{E}-02$ & $0.0 \mathrm{E}+0$ & $0.0 \mathrm{E}+0$ & $0.0 \mathrm{E}+0$ \\
\hline & $\checkmark$ & & & ${ }^{142} \mathrm{La}$ & $7.0 \mathrm{E}-03$ & $1.3 \mathrm{E}-02$ & $0.0 \mathrm{E}+0$ & $0.0 \mathrm{E}+0$ & $0.0 \mathrm{E}+0$ \\
\hline
\end{tabular}




\begin{tabular}{|c|c|c|c|c|c|c|c|c|c|}
\hline \multirow[b]{2}{*}{ 照 } & & & & & \multicolumn{5}{|c|}{ Fraction of activity from isotope } \\
\hline & $\begin{array}{l}\ddot{\Xi} \\
\frac{\mathbb{\Xi}}{2} \\
\widetilde{q}\end{array}$ & 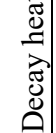 & 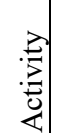 & $\begin{array}{l}0 \\
\stackrel{0}{0} \\
0 \\
0 \\
0\end{array}$ & $0 \mathrm{~s}$ & $30 \mathrm{~m}$ & $5 \mathrm{~d}$ & $25 \mathrm{~d}$ & $500 \mathrm{~d}$ \\
\hline & $\bar{\checkmark}$ & & & $\sqrt{93} \mathrm{Y}$ & $6.3 \mathrm{E}-03$ & $1.3 \mathrm{E}-02$ & $1.3 \mathrm{E}-05$ & $1.6 \mathrm{E}-19$ & $0.0 \mathrm{E}+0$ \\
\hline & $\checkmark$ & & & ${ }^{92} \mathrm{Y}$ & $5.5 \mathrm{E}-03$ & $1.1 \mathrm{E}-02$ & $1.0 \mathrm{E}-11$ & $0.0 \mathrm{E}+0$ & $0.0 \mathrm{E}+0$ \\
\hline & $\checkmark$ & & & ${ }^{105} \mathrm{Ru}$ & $5.0 \mathrm{E}-03$ & $1.0 \mathrm{E}-02$ & $3.9 \mathrm{E}-03$ & $6.4 \mathrm{E}-07$ & $0.0 \mathrm{E}+0$ \\
\hline & $\checkmark$ & $\checkmark$ & & ${ }^{238} \mathrm{~Np}$ & $4.4 \mathrm{E}-03$ & $9.1 \mathrm{E}-03$ & $6.1 \mathrm{E}-03$ & $1.8 \mathrm{E}-05$ & 3.6E-08 \\
\hline & $\checkmark$ & & & ${ }^{105} \mathrm{Ru}$ & $5.4 \mathrm{E}-03$ & $1.1 \mathrm{E}-02$ & $2.9 \mathrm{E}-10$ & $0.0 \mathrm{E}+0$ & $0.0 \mathrm{E}+0$ \\
\hline & $\checkmark$ & $\checkmark$ & & ${ }^{242} \mathrm{Cm}$ & $6.1 \mathrm{E}-04$ & $1.3 \mathrm{E}-03$ & $4.3 \mathrm{E}-03$ & $7.9 \mathrm{E}-03$ & $5.4 \mathrm{E}-03$ \\
\hline & $\checkmark$ & & & ${ }^{134} \mathrm{Te}$ & $8.1 \mathrm{E}-03$ & $1.0 \mathrm{E}-02$ & $0.0 \mathrm{E}+0$ & $0.0 \mathrm{E}+0$ & $0.0 \mathrm{E}+0$ \\
\hline & $\checkmark$ & & & ${ }^{91} \mathrm{Sr}$ & $5.0 \mathrm{E}-03$ & $9.9 \mathrm{E}-03$ & $6.3 \mathrm{E}-06$ & $1.3 \mathrm{E}-20$ & $0.0 \mathrm{E}+0$ \\
\hline & $\checkmark$ & & & ${ }^{92} \mathrm{Sr}$ & $5.4 \mathrm{E}-03$ & $9.8 \mathrm{E}-03$ & $1.8 \mathrm{E}-15$ & $0.0 \mathrm{E}+0$ & $0.0 \mathrm{E}+0$ \\
\hline & $\checkmark$ & & & ${ }^{101} \mathrm{Tc}$ & 7.9E-03 & $9.4 \mathrm{E}-03$ & $0.0 \mathrm{E}+0$ & $0.0 \mathrm{E}+0$ & $0.0 \mathrm{E}+0$ \\
\hline & $\checkmark$ & & & ${ }^{145} \mathrm{Pr}$ & 4.6E-03 & $9.1 \mathrm{E}-03$ & $3.0 \mathrm{E}-08$ & $0.0 \mathrm{E}+0$ & $0.0 \mathrm{E}+0$ \\
\hline & $\checkmark$ & & & ${ }^{135} \mathrm{Xe}$ & $3.4 \mathrm{E}-03$ & $7.5 \mathrm{E}-03$ & $2.0 \mathrm{E}-05$ & $6.5 \mathrm{E}-21$ & $0.0 \mathrm{E}+0$ \\
\hline & $\checkmark$ & & & ${ }^{133 \mathrm{~m}} \mathrm{Te}$ & 4.6E-03 & $6.5 \mathrm{E}-03$ & $0.0 \mathrm{E}+0$ & $0.0 \mathrm{E}+0$ & $0.0 \mathrm{E}+0$ \\
\hline & $\checkmark$ & & & ${ }^{85} \mathrm{Kr}$ & $9.2 \mathrm{E}-05$ & $1.9 \mathrm{E}-04$ & $6.5 \mathrm{E}-04$ & $1.3 \mathrm{E}-03$ & $6.2 \mathrm{E}-03$ \\
\hline & $\checkmark$ & & & ${ }^{149} \mathrm{Pm}$ & $2.5 \mathrm{E}-03$ & $5.1 \mathrm{E}-03$ & $3.8 \mathrm{E}-03$ & $1.4 \mathrm{E}-05$ & $0.0 \mathrm{E}+0$ \\
\hline & $\checkmark$ & & & ${ }^{153} \mathrm{Sm}$ & $2.7 \mathrm{E}-03$ & $5.5 \mathrm{E}-03$ & $3.2 \mathrm{E}-03$ & $5.0 \mathrm{E}-06$ & $0.0 \mathrm{E}+0$ \\
\hline & $\checkmark$ & & & ${ }^{131} \mathrm{Te}$ & $3.9 \mathrm{E}-03$ & $6.2 \mathrm{E}-03$ & $1.4 \mathrm{E}-04$ & $1.2 \mathrm{E}-08$ & $0.0 \mathrm{E}+0$ \\
\hline $\bar{\checkmark}$ & $\checkmark$ & $\sqrt{ }$ & & ${ }^{154} \mathrm{Eu}$ & $9.1 \mathrm{E}-05$ & $1.9 \mathrm{E}-04$ & $6.4 \mathrm{E}-04$ & $1.3 \mathrm{E}-03$ & $6.0 \mathrm{E}-03$ \\
\hline & $\checkmark$ & & & $91 \mathrm{~m} Y$ & $2.9 \mathrm{E}-03$ & $6.0 \mathrm{E}-03$ & $4.0 \mathrm{E}-06$ & $8.1 \mathrm{E}-21$ & $0.0 \mathrm{E}+0$ \\
\hline & $\checkmark$ & & & ${ }^{243} \mathrm{Pu}$ & $2.9 \mathrm{E}-03$ & $5.6 \mathrm{E}-03$ & 1.1E-09 & $2.7 \mathrm{E}-13$ & $1.4 \mathrm{E}-12$ \\
\hline & $\sqrt{ }$ & & & ${ }^{88} \mathrm{Rb}$ & $2.9 \mathrm{E}-03$ & $5.6 \mathrm{E}-03$ & $4.3 \mathrm{E}-15$ & $0.0 \mathrm{E}+0$ & $0.0 \mathrm{E}+0$ \\
\hline & $\checkmark$ & & & ${ }^{146} \mathrm{Pr}$ & $3.7 \mathrm{E}-03$ & $5.3 \mathrm{E}-03$ & $0.0 \mathrm{E}+0$ & $0.0 \mathrm{E}+0$ & $0.0 \mathrm{E}+0$ \\
\hline$\checkmark$ & $\checkmark$ & $\checkmark$ & & ${ }^{238} \mathrm{Pu}$ & $6.7 \mathrm{E}-05$ & $1.4 \mathrm{E}-04$ & $4.8 \mathrm{E}-04$ & $9.6 \mathrm{E}-04$ & $5.1 \mathrm{E}-03$ \\
\hline & $\checkmark$ & & & ${ }^{88} \mathrm{Kr}$ & $2.8 \mathrm{E}-03$ & $5.1 \mathrm{E}-03$ & $3.8 \mathrm{E}-15$ & $0.0 \mathrm{E}+0$ & $0.0 \mathrm{E}+0$ \\
\hline & $\checkmark$ & & & ${ }^{141} \mathrm{Ba}$ & 7.3E-03 & $4.9 \mathrm{E}-03$ & $0.0 \mathrm{E}+0$ & $0.0 \mathrm{E}+0$ & $0.0 \mathrm{E}+0$ \\
\hline & $\checkmark$ & & & ${ }^{94} \mathrm{Y}$ & $6.7 \mathrm{E}-03$ & $4.8 \mathrm{E}-03$ & $0.0 \mathrm{E}+0$ & $0.0 \mathrm{E}+0$ & $0.0 \mathrm{E}+0$ \\
\hline & $\checkmark$ & & & ${ }^{148} \mathrm{Pm}$ & $1.1 \mathrm{E}-03$ & $2.2 \mathrm{E}-03$ & $4.0 \mathrm{E}-03$ & $7.2 \mathrm{E}-04$ & $2.1 \mathrm{E}-07$ \\
\hline$\checkmark$ & $\sqrt{ }$ & $\sqrt{ }$ & & ${ }^{244} \mathrm{Cm}$ & $6.4 \mathrm{E}-05$ & $1.3 \mathrm{E}-04$ & $4.5 \mathrm{E}-04$ & $9.1 \mathrm{E}-04$ & $4.5 \mathrm{E}-03$ \\
\hline & $\checkmark$ & $\checkmark$ & & ${ }^{104} \mathrm{Tc}$ & $6.3 \mathrm{E}-03$ & $4.4 \mathrm{E}-03$ & $0.0 \mathrm{E}+0$ & $0.0 \mathrm{E}+0$ & $0.0 \mathrm{E}+0$ \\
\hline & $\sqrt{ }$ & $\sqrt{ }$ & & ${ }^{136} \mathrm{Cs}$ & $6.3 \mathrm{E}-04$ & $1.3 \mathrm{E}-03$ & $3.4 \mathrm{E}-03$ & $2.4 \mathrm{E}-03$ & $1.7 \mathrm{E}-13$ \\
\hline & $\checkmark$ & & & ${ }^{125} \mathrm{Sb}$ & $7.2 \mathrm{E}-05$ & $1.5 \mathrm{E}-04$ & $5.1 \mathrm{E}-04$ & $1.0 \mathrm{E}-03$ & $3.8 \mathrm{E}-03$ \\
\hline & $\checkmark$ & & & ${ }^{109} \mathrm{Pd}$ & $2.0 \mathrm{E}-03$ & $3.9 \mathrm{E}-03$ & $3.2 \mathrm{E}-05$ & $1.8 \mathrm{E}-15$ & $0.0 \mathrm{E}+0$ \\
\hline & $\checkmark$ & & & $\frac{101}{100}$ & $7.9 \mathrm{E}-03$ & $3.9 \mathrm{E}-03$ & $0.0 \mathrm{E}+0$ & $0.0 \mathrm{E}+0$ & $0.0 \mathrm{E}+0$ \\
\hline & $\checkmark$ & & & ${ }^{138} \mathrm{Xe}$ & $7.8 \mathrm{E}-03$ & $3.7 \mathrm{E}-03$ & $0.0 \mathrm{E}+0$ & $0.0 \mathrm{E}+0$ & $0.0 \mathrm{E}+0$ \\
\hline & $\checkmark$ & & & ${ }^{87} \mathrm{Kr}$ & $2.1 \mathrm{E}-03$ & $3.3 \mathrm{E}-03$ & $0.0 \mathrm{E}+0$ & $0.0 \mathrm{E}+0$ & $0.0 \mathrm{E}+0$ \\
\hline & $\checkmark$ & & & ${ }^{143} \mathrm{La}$ & $6.7 \mathrm{E}-03$ & $3.2 \mathrm{E}-03$ & $0.0 \mathrm{E}+0$ & $0.0 \mathrm{E}+0$ & $0.0 \mathrm{E}+0$ \\
\hline & $\checkmark$ & & & ${ }^{135 \mathrm{~m} X \mathrm{e}}$ & $2.0 \mathrm{E}-03$ & $3.2 \mathrm{E}-03$ & 3.4E- 08 & $0.0 \mathrm{E}+0$ & $0.0 \mathrm{E}+0$ \\
\hline & $\checkmark$ & & & ${ }^{149} \mathrm{Nd}$ & $1.8 \mathrm{E}-03$ & $3.1 \mathrm{E}-03$ & $1.6 \mathrm{E}-23$ & $0.0 \mathrm{E}+0$ & $0.0 \mathrm{E}+0$ \\
\hline & $\checkmark$ & & & ${ }^{131} \mathrm{Sb}$ & $3.6 \mathrm{E}-03$ & $3.0 \mathrm{E}-03$ & $0.0 \mathrm{E}+0$ & $0.0 \mathrm{E}+0$ & $0.0 \mathrm{E}+0$ \\
\hline & $\checkmark$ & & & ${ }^{133} \mathrm{Te}$ & $4.7 \mathrm{E}-03$ & $3.0 \mathrm{E}-03$ & $0.0 \mathrm{E}+0$ & $0.0 \mathrm{E}+0$ & $0.0 \mathrm{E}+0$ \\
\hline & $\checkmark$ & & & ${ }^{105 m} \mathrm{Rh}$ & $1.5 \mathrm{E}-03$ & $3.0 \mathrm{E}-03$ & $8.2 \mathrm{E}-11$ & $0.0 \mathrm{E}+0$ & $0.0 \mathrm{E}+0$ \\
\hline & $\checkmark$ & & & ${ }^{107} \mathrm{Rh}$ & $3.1 \mathrm{E}-03$ & $3.0 \mathrm{E}-03$ & $0.0 \mathrm{E}+0$ & $0.0 \mathrm{E}+0$ & $0.0 \mathrm{E}+0$ \\
\hline & $\checkmark$ & & & 148m $\mathrm{Pm}$ & $2.6 \mathrm{E}-04$ & 5.3E-04 & $1.7 \mathrm{E}-03$ & $2.4 \mathrm{E}-03$ & $4.3 \mathrm{E}-06$ \\
\hline & $\checkmark$ & & & ${ }^{155} \mathrm{Eu}$ & $4.6 \mathrm{E}-05$ & $9.5 \mathrm{E}-05$ & $3.3 \mathrm{E}-04$ & $6.5 \mathrm{E}-04$ & $2.8 \mathrm{E}-03$ \\
\hline & $\checkmark$ & & & ${ }^{129} \mathrm{Te}$ & $1.3 \mathrm{E}-03$ & $2.6 \mathrm{E}-03$ & $7.9 \mathrm{E}-04$ & $1.1 \mathrm{E}-03$ & $3.0 \mathrm{E}-07$ \\
\hline & $\checkmark$ & & & ${ }^{129} \mathrm{Sb}$ & $1.3 \mathrm{E}-03$ & $2.6 \mathrm{E}-03$ & $5.9 \mathrm{E}-11$ & $0.0 \mathrm{E}+0$ & $0.0 \mathrm{E}+0$ \\
\hline & $\checkmark$ & & & ${ }^{102} \mathrm{Tc}$ & $7.5 \mathrm{E}-03$ & $2.5 \mathrm{E}-03$ & $0.0 \mathrm{E}+0$ & $0.0 \mathrm{E}+0$ & $0.0 \mathrm{E}+0$ \\
\hline
\end{tabular}




\begin{tabular}{|c|c|c|c|c|c|c|c|c|c|}
\hline \multirow[b]{2}{*}{ 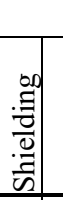 } & \multirow[b]{2}{*}{ 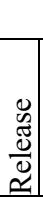 } & \multirow[b]{2}{*}{ 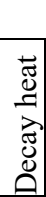 } & \multirow[b]{2}{*}{ 党 } & \multirow[b]{2}{*}{$\begin{array}{l}\stackrel{0}{0} \\
\text { Oे } \\
0 \\
0\end{array}$} & \multicolumn{5}{|c|}{ Fraction of activity from isotope } \\
\hline & & & & & $0 \mathrm{~s}$ & $30 \mathrm{~m}$ & $5 \mathrm{~d}$ & $25 \mathrm{~d}$ & $500 \mathrm{~d}$ \\
\hline & $\checkmark$ & & & ${ }^{102} \mathrm{Mo}$ & $7.5 \mathrm{E}-03$ & $2.5 \mathrm{E}-03$ & $0.0 \mathrm{E}+0$ & $0.0 \mathrm{E}+0$ & $0.0 \mathrm{E}+0$ \\
\hline & $\checkmark$ & & & ${ }^{89} \mathrm{Rb}$ & $3.8 \mathrm{E}-03$ & $2.4 \mathrm{E}-03$ & $0.0 \mathrm{E}+0$ & $0.0 \mathrm{E}+0$ & $0.0 \mathrm{E}+0$ \\
\hline & $\checkmark$ & & & ${ }^{85 \mathrm{~m}} \mathrm{Kr}$ & $1.1 \mathrm{E}-03$ & $2.1 \mathrm{E}-03$ & $6.9 \mathrm{E}-11$ & $0.0 \mathrm{E}+0$ & $0.0 \mathrm{E}+0$ \\
\hline & $\checkmark$ & & & ${ }^{129 \mathrm{~m} T e}$ & $2.0 \mathrm{E}-04$ & $4.0 \mathrm{E}-04$ & $1.3 \mathrm{E}-03$ & $1.7 \mathrm{E}-03$ & $4.8 \mathrm{E}-07$ \\
\hline & $\checkmark$ & & & ${ }^{95} \mathrm{Y}$ & $7.0 \mathrm{E}-03$ & $2.0 \mathrm{E}-03$ & $0.0 \mathrm{E}+0$ & $0.0 \mathrm{E}+0$ & $0.0 \mathrm{E}+0$ \\
\hline & $\sqrt{ }$ & & & ${ }^{142} \mathrm{Ba}$ & $6.8 \mathrm{E}-03$ & $2.0 \mathrm{E}-03$ & $0.0 \mathrm{E}+0$ & $0.0 \mathrm{E}+0$ & $0.0 \mathrm{E}+0$ \\
\hline & $\checkmark$ & & & ${ }^{151} \mathrm{Pm}$ & $9.3 \mathrm{E}-04$ & $1.9 \mathrm{E}-03$ & $3.6 \mathrm{E}-04$ & $5.8 \mathrm{E}-09$ & $0.0 \mathrm{E}+0$ \\
\hline & $\checkmark$ & & & ${ }^{131 \mathrm{~m} T e}$ & $8.9 \mathrm{E}-04$ & $1.8 \mathrm{E}-03$ & $5.2 \mathrm{E}-04$ & 4.7E-08 & $0.0 \mathrm{E}+0$ \\
\hline & $\checkmark$ & & & ${ }^{127} \mathrm{Te}$ & $4.2 \mathrm{E}-04$ & $8.6 \mathrm{E}-04$ & $1.5 \mathrm{E}-03$ & $6.0 \mathrm{E}-04$ & $1.4 \mathrm{E}-04$ \\
\hline & $\checkmark$ & & & ${ }^{242} \mathrm{Am}$ & $9.2 \mathrm{E}-04$ & $1.8 \mathrm{E}-03$ & $3.7 \mathrm{E}-05$ & $1.5 \mathrm{E}-06$ & $7.8 \mathrm{E}-06$ \\
\hline & $\checkmark$ & & & ${ }^{139} \mathrm{Cs}$ & $7.9 \mathrm{E}-03$ & $1.8 \mathrm{E}-03$ & $0.0 \mathrm{E}+0$ & $0.0 \mathrm{E}+0$ & $0.0 \mathrm{E}+0$ \\
\hline & $\checkmark$ & & & ${ }^{146} \mathrm{Ce}$ & $3.7 \mathrm{E}-03$ & $1.7 \mathrm{E}-03$ & $0.0 \mathrm{E}+0$ & $0.0 \mathrm{E}+0$ & $0.0 \mathrm{E}+0$ \\
\hline & $\checkmark$ & & & ${ }^{144 \mathrm{~m}} \mathrm{Pr}$ & $8.2 \mathrm{E}-05$ & $1.3 \mathrm{E}-04$ & $4.2 \mathrm{E}-04$ & $8.1 \mathrm{E}-04$ & $1.3 \mathrm{E}-03$ \\
\hline & $\checkmark$ & & & ${ }^{127} \mathrm{Sb}$ & $4.5 \mathrm{E}-04$ & $9.2 \mathrm{E}-04$ & $1.3 \mathrm{E}-03$ & $7.2 \mathrm{E}-05$ & $0.0 \mathrm{E}+0$ \\
\hline & $\checkmark$ & & & ${ }^{130} \mathrm{Sb}$ & $1.2 \mathrm{E}-03$ & $1.5 \mathrm{E}-03$ & $0.0 \mathrm{E}+0$ & $0.0 \mathrm{E}+0$ & $0.0 \mathrm{E}+0$ \\
\hline & $\checkmark$ & & & ${ }^{244 \mathrm{~m}} \mathrm{Am}$ & $1.5 \mathrm{E}-03$ & $1.4 \mathrm{E}-03$ & $0.0 \mathrm{E}+0$ & $0.0 \mathrm{E}+0$ & $0.0 \mathrm{E}+0$ \\
\hline & $\checkmark$ & & & ${ }^{147} \mathrm{Pr}$ & $2.9 \mathrm{E}-03$ & $1.4 \mathrm{E}-03$ & $0.0 \mathrm{E}+0$ & $0.0 \mathrm{E}+0$ & $0.0 \mathrm{E}+0$ \\
\hline & $\checkmark$ & & & ${ }^{128 \mathrm{~m}} \mathrm{Sb}$ & $6.8 \mathrm{E}-04$ & $1.1 \mathrm{E}-03$ & $0.0 \mathrm{E}+0$ & $0.0 \mathrm{E}+0$ & $0.0 \mathrm{E}+0$ \\
\hline & $\checkmark$ & & & ${ }^{95 \mathrm{~m}} \mathrm{Nb}$ & $7.9 \mathrm{E}-05$ & $1.6 \mathrm{E}-04$ & $5.5 \mathrm{E}-04$ & $9.1 \mathrm{E}-04$ & $2.7 \mathrm{E}-05$ \\
\hline & $\checkmark$ & & & ${ }^{83 \mathrm{~m} K r}$ & $5.2 \mathrm{E}-04$ & $1.1 \mathrm{E}-03$ & $1.5 \mathrm{E}-10$ & $2.6 \mathrm{E}-10$ & 2.9E-11 \\
\hline & $\checkmark$ & & & ${ }^{84} \mathrm{Br}$ & $8.8 \mathrm{E}-04$ & $1.0 \mathrm{E}-03$ & $0.0 \mathrm{E}+0$ & $0.0 \mathrm{E}+0$ & $0.0 \mathrm{E}+0$ \\
\hline
\end{tabular}




\section{APPENDIX B. DEPLETION STEP SIZE}

Polaris PWR assembly depletion used burnup points at $0.1,1,2,4,6,8,10,12,14,16,18,20,22.5,25$, $27.5,30,32.5,35,37.5,40,44,48,52,56,60,64,68,72,76$, and $80 \mathrm{GWd} / \mathrm{MTU}$. To confirm the adequacy of depletion step size, two additional cases were run. The reactivity difference is shown in Figure B.1 with a "2 GWd/T max" case which has all burnup steps halved compared to the base case and a "1 GWd/T max" with uniform $1 \mathrm{GWd}$ /MTU steps after $5 \mathrm{GWd}$ /MTU. The observed differences (max $66 \mathrm{pcm}$ ) are deemed acceptable for the evaluation of HALEU and HBU trends.

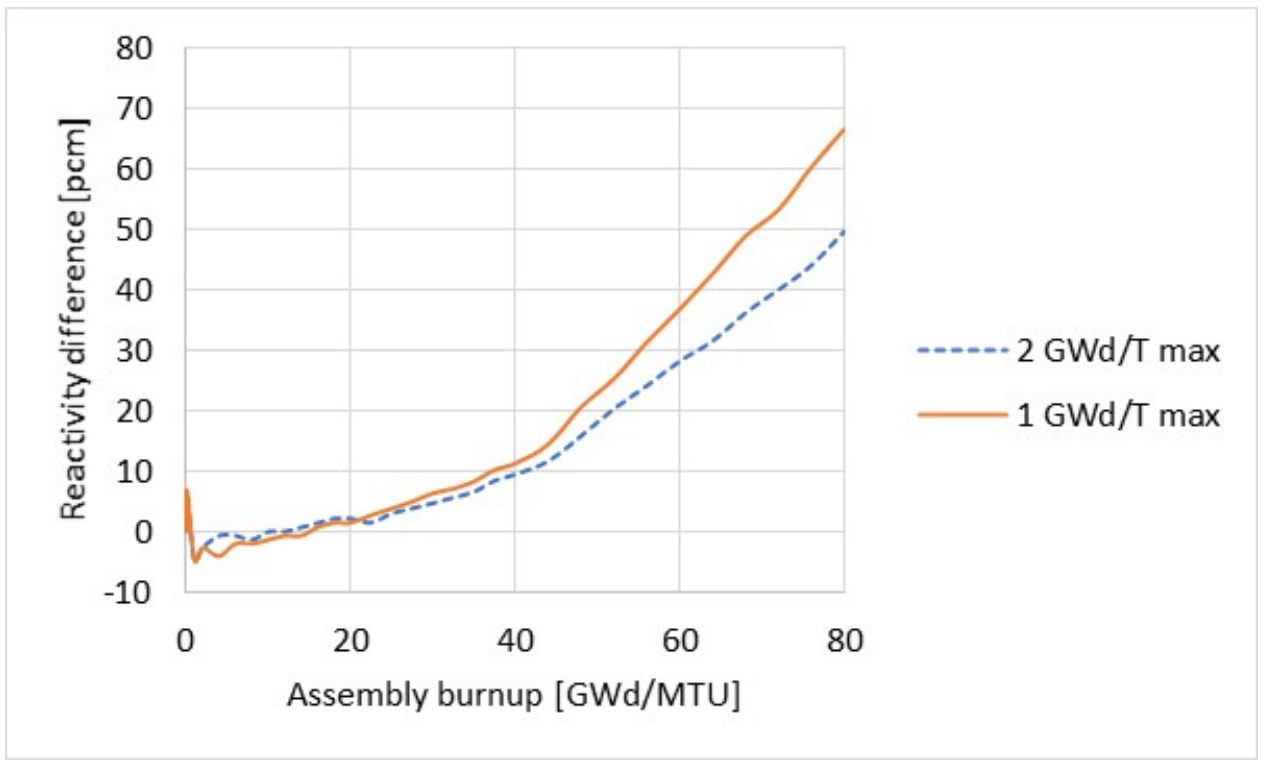

Figure B.1. Reactivity effect of depletion step size. 


\section{APPENDIX C. COMPUTER CODE INPUT AND OUTPUT}

Computer input, computer output, and spreadsheets used to produce the data tables and plots in this report are described in this appendix, organized by section.

\section{Section 3}

Table C.1. Section 3.1 Spreadsheets and computer code runs

\begin{tabular}{|l|l|l|l|}
\hline Data & Spreadsheet & Tab & Case \\
\hline Fig. 2a & W17_depl_branch_CR_0MTC.xlsx & U-PU_plot_data & W17x17_5wtp_80g_branches_0ppmMTC_CR.inp \\
\hline Fig. 2b & W17_dep1_branch_CR_0MTC.xlsx & U-PU_plot_data & W17x17_8wtp_80g_branches_0ppmMTC_CR.inp \\
\hline Fig. 3 & W17_lattice_results_rev3.xlsx & 5_wt\%_80_lattice & $\begin{array}{l}\text { W17x17_5wtp_80g_branches2.inp } \\
\text { W17x17_8wtp_80g_branches2.inp }\end{array}$ \\
\hline Fig. 4 & W17_depl_branch_CR_0MTC.xlsx & Fluxes & $\begin{array}{l}\text { W17x17_5wtp_80g_branches_0ppmMTC_CR.inp } \\
\text { W17x17_8wtp_80g_branches_0ppmMTC_CR.inp }\end{array}$ \\
\hline
\end{tabular}

Table C.2. Section 3.2 Spreadsheets and computer code runs

\begin{tabular}{|l|l|l|l|}
\hline Data & Spreadsheet & Tab & Case \\
\hline Fig. 5 & W17_dep1_branch_CR_0MTC.xlsx & Kinf_plot & $\begin{array}{l}\text { W17x17_5wtp_80g_branches2.inp } \\
\text { W17x17_6wtp_80g_branches2.inp } \\
\text { W17x17_8wtp_80g_branches2.inp }\end{array}$ \\
\hline Fig. 6 & W17_dep1_branch_CR_0MTC.xlsx & Reactivity_plot & Same as above \\
\hline Fig. 7 & W17_depl_branch_CR_0MTC.xlsx & DBW_plot & Same as above \\
\hline Fig. 8 & W17_dep1_branch_CR_0MTC.xlsx & Depletion_boron_plot & Same as above \\
\hline Fig. 9 & W17_dep1_branch_CR_0MTC.xlsx & Kinf_plot_0ppm & $\begin{array}{l}\text { W17x17_5wtp_80g_branches2.inp } \\
\text { W17x17_6wtp_80g_branches_modbor.inp } \\
\text { W17x17_8wtp_80g_branches_modbor.inp }\end{array}$ \\
\hline Fig. 10 & W17_dep1_branch_CR_0MTC.xlsx & DTC_plot & Same as above \\
\hline Fig. 11 & W17_depl_branch_CR_0MTC.xlsx & MTC_plot_0ppm & $\begin{array}{l}\text { W17x17_5wtp_80g_branches_0ppmMTC_CR.inp } \\
\text { W17x17_8wtp_80g_branches_0ppmMTC_CR.inp }\end{array}$ \\
\hline Fig. 12 & W17_depl_branch_CR_0MTC.xlsx & CR_plot & Same as above \\
\hline
\end{tabular}

Table C.3. Section 3.3 Spreadsheets and computer code runs

\begin{tabular}{|l|l|l|l|}
\hline Data & Spreadsheet & Tab & Case \\
\hline Fig. 13 & W17_dep_branch_CR_0MTC.xlsx & Plot_kinf_56v252 & W17x17_5wtp_80g_CRbranches_252g.inp \\
& & & W17x17_8wtp_80g_CRbranches_252g.inp \\
& & & W17x17_5wtp_80g_branches_0ppmMTC_CR.inp \\
& & & W17x17_8wtp_80g_branches_0ppmMTC_CR.inp \\
\hline Fig. 14 & W17_depl_branch_CR_0MTC.xlsx & Plot_dtc_56v252 & W17x17_5wtp_80g_branches2.inp \\
& & & W17x17_8wtp_80g_branches_modbor.inp \\
& & & W17x17_5wtp_80g_252g.inp \\
& & & W17x17_8wtp_80g_252g.inp \\
\hline Fig. 15 & W17_depl_branch_CR_0MTC.xlsx & Plot_mtc 56v252 & Same as above \\
\hline Fig. 16 & W17_depl_branch_CR_0MTC.xlsx & Plot_BW 56v252 & Same as above \\
\hline Fig. 17 & W17_dep1_branch_CR_0MTC.xlsx & Plot_CRW_56v252 & W17x17_5wtp_80g_CRbranches_252g.inp \\
& & & W17x17_8wtp_80g_CRbranches_252g.inp \\
& & & W17x17_5wtp_80g_branches_0ppmMTC_CR.inp \\
& & & W17x17_8wtp_80g_branches_0ppmMTC_CR.inp \\
\hline Fig. 18 & W17_dep1_branch_CR_0MTC.xlsx & 8wo_depl_1520CR & W17x17_5wtp_80g_branches2.inp \\
& & & W17x17_8wtp_80g_branches_modbor.inp \\
& & & W17x17_5wtp_80g_branches_0ppmMTC_CR.inp \\
& & & W17x17_8wtp_80g_branches_0ppmMTC_CR.inp \\
\hline
\end{tabular}


Table C.4. Section 3.4 Spreadsheets and computer code runs

\begin{tabular}{|l|l|l|l|}
\hline Data & Spreadsheet & Tab & Case \\
\hline Fig. 19 & W17_depl_branch_CR_0MTC.xlsx & Pincell_mg_vs_CE & Polaris_pincell_1520ppm_8wt_56g_90bu.inp \\
& & & TRITON_pincell_1520ppm_8wt_56g_90bu.inp \\
& & & TRITON_pincell_1520ppm_8wt_252g_90bu.inp \\
& & & TRITON_pincell_1520ppm_8wt_CE_90bu.inp \\
\hline
\end{tabular}

Table C.5. Section 3.5 Spreadsheets and computer code runs

\begin{tabular}{|l|l|l|l|}
\hline Data & Spreadsheet & Tab & Case \\
\hline Fig. 20 & W17_lattice_results_rev3.xlsx & Plot_max_pin & $\begin{array}{l}\text { W17x17_5wtp_80g_branches2.inp } \\
\text { W17x17_6wtp_80g_branches2.inp } \\
\text { W17x17_8wtp_80g_branches2.inp }\end{array}$ \\
\hline Fig. 21 & W17 lattice_results_rev3.xlsx & Plot_min_pin & Same as above \\
\hline Fig. 22 & W17 lattice_results_rev3.xlsx & Plot_max_bu & Same as above \\
\hline Fig. 23 & W17_lattice_results_rev3.xlsx & Plot_ring1 & Same as above \\
\hline Fig. 24 & W17 lattice results_rev3.xlsx & Plot_ring2 & Same as above \\
\hline Fig. 25 & W17_lattice_results_rev3.xlsx & Plot_ring3 & Same as above \\
\hline
\end{tabular}

Table C.6. Section 3.6 Spreadsheets and computer code runs

\begin{tabular}{|l|l|l|l|}
\hline Data & Spreadsheet & Tab & Case \\
\hline Fig. 26 & W17_lattice_results_rev3.xlsx & Plot_eta & $\begin{array}{l}\text { W17x17_5wtp_80g_branches2.inp } \\
\text { W17x17_6wtp_80g_branches2.inp } \\
\text { W17x17_8wtp_80g_branches2.inp }\end{array}$ \\
\hline Fig. 27 & W17_lattice_results_rev3.xlsx & Plot_f & Same as above \\
\hline Fig. 28 & W17_lattice_results_rev3.xlsx & Plot_p & Same as above \\
\hline Fig. 29 & W17_lattice_results_rev3.xlsx & Plot_eps & Same as above \\
\hline Fig. 30 & W17_lattice_results_rev3.xlsx & Plot_removal1 & Same as above \\
\hline Fig. 31 & W17_lattice_results_rev3.xlsx & Plot_abs1 & Same as above \\
\hline Fig. 32 & W17_lattice_results_rev3.xlsx & N/A_Fulcrum plot) & None \\
\hline Fig. 33 & W17_lattice_results_rev3.xlsx & Plot_fiss1 & W17x17_5wtp_80g_branches2.inp \\
& & & W17x17_6wtp_80g_branches2.inp \\
& & & W17x17_8wtp_80g_branches2.inp \\
\hline Fig. 34 & W17_lattice_results_rev3.xlsx & Plot rem2 & Same as above \\
\hline Fig. 35 & W17_lattice_results_rev3.xlsx & Plot_eff_abs2 & Same as above \\
\hline Fig. 36 & W17_lattice_results_rev3.xlsx & Plot_fiss2 & Same as above \\
\hline Fig. 37 & W17_lattice_results_rev3.xlsx & Plot_B-eff & Same as above \\
\hline Fig. 38 & W17_lattice_results_rev3.xlsx & Plot_L-eff & Same as above \\
\hline
\end{tabular}




\section{Section 4}

Table C.7. Section 4.1 Spreadsheets and computer code runs

\begin{tabular}{|l|l|l|l|}
\hline Data & Spreadsheet & Tab & Case \\
\hline Tbl. 4 & W17_TSUNAMI_SFP.xlsx & N/A & W17x17_5wtp_60G_5d_for_EPRIrack.inp (Polaris) \\
& & & W17x17_8wtp_84G_5d_for_EPRIrack.inp \\
& W17x17_8wtp_94G_5d_for_EPRIrack.inp \\
& & & Pincell_5wt_606G_5d_decay_for_EPRIrack.inp (ORIGEN) \\
& & & Pincell_8wt_84G_5d_decay_for_EPRIrack.inp \\
& & Pincell_5wt_94G_5d_decay_for_EPRIrack.inp \\
& & & EPRI_pincell_5wt_60G_5d_TSUNAMI.inp (TSUNAMI) \\
& & & EPRI_pincell_8wt_84G_5d_TSUNAMI.inp \\
& & & \\
& & &
\end{tabular}

Table C.8. Section 4.2 Spreadsheets and computer code runs

\begin{tabular}{|l|l|l|l|}
\hline Data & Spreadsheet & Tab & Case \\
\hline Fig. 40 & Rerun_SAMPLER_pincell.xlsm & $\begin{array}{l}\text { Polaris_depl_resp_5wtp } \\
\text { Polaris_depl_resp_8wtp }\end{array}$ & $\begin{array}{l}\text { W17X17_pincell_84G_smplrdepl_5wtp.inp } \\
\text { W17X17_pincell_84G_smplrdepl_8wtp.inp }\end{array}$ \\
\hline Tbl. 5 & Rerun_SAMPLER_pincell.xlsm & Sampler_depl_plot & Same as above \\
\hline
\end{tabular}

Table C.9. Section 4.3 Spreadsheets and computer code runs

\begin{tabular}{|l|l|l|l|}
\hline Data & Spreadsheet & Tab & Case \\
\hline Tbl. 6 & HighBU_5wtpct_104IFBA_rev2.xlsx & Halfnuc_worth_50G & W17x17_test_80G.inp (Polaris) \\
& & Halfnuc_worth_80G & W17x17_60G_5d_decay.inp (ORIGEN) \\
& & & W17x17_80G_5d_decay.inp \\
& & & $\begin{array}{l}\text { Pincell_60GWD_5wtpt_halfnuc_stack.inp (Polaris) } \\
\text { Pincell_80GWD_5wtpt_halfnuc_stack.inp }\end{array}$ \\
\hline
\end{tabular}




\section{Section 5}

In section 5, the following input Polaris cases were used to investigate the inventory behavior.

- W17x17_e5 b60G.inp - W17x17 $5 \mathrm{wt} \% 60 \mathrm{GWd} / \mathrm{MTU}$ lattice

- W17x17_e8_b80G.inp - W17x17 8 wt\% 80 GWd/MTU lattice

- W17x17_e8_b60G.inp - W17x17 8 wt\% 60 GWd/MTU lattice

- W17x17_e6.5_b80G.inp - W17x17 6.5 wt\% 80 GWd/MTU lattice

A set of ORIGEN decay calculations based on the Polaris discharge inventory at 60 and $80 \mathrm{GWd} / \mathrm{MTU}$ were used to analyze decay heat and activity. The ORIGEN decay heat and activity data was postprocessed into the following spreadsheets to create the tables included in this report.

Table C.10. Section 5 Spreadsheets and computer code runs

\begin{tabular}{|c|c|c|c|}
\hline Data & Spreadsheet & Tab & Case \\
\hline Tbl. 8 & Decay_heat_figures.xlsx & Relative differences & $\begin{array}{l}\text { W17x17_e5_b60G.inp (Polaris) } \\
\text { W17x17_e8_b80G.inp } \\
\text { W17x17_e8_b60G.inp } \\
\text { W17x17_e6.5_b80G.inp } \\
\text { origen/W17x17_e5_b60G.inp (ORIGEN) } \\
\text { origen/W17x17_e5_b80G.inp } \\
\text { origen/W17x17_e6.5_b60G.inp } \\
\text { origen/W17x17_e6.5_b80G.inp } \\
\text { origen/W17x17_e8_b60G.inp } \\
\text { origen/W17x17_e8_b80G.inp }\end{array}$ \\
\hline Tbl. 9 & Decay_heat_figures.xlsx & Absolute differences & Same as above \\
\hline Tbl. 10 & Activity_figures.xlsx & Relative differences & Same as above \\
\hline Tbl. 11 & Activity_figures.xlsx & Absolute differences & Same as above \\
\hline Tbl. 12 & Release_Inventory.xlsx & $\begin{array}{l}\text { Relative differences iso } \\
\text { basis }\end{array}$ & Same as above \\
\hline Tbl. 13 & Shielding_Activity.xlsx & $\begin{array}{l}\text { Relative differences iso } \\
\text { basis }\end{array}$ & Same as above \\
\hline Tbl. 14 & Shielding_Activity.xlsx & SpontFisDiff & Same as above \\
\hline Tbl. 15 & Criticality_Inventory.xlsx & $\begin{array}{l}\text { Relative differences } \\
\text { total mass basis }\end{array}$ & Same as above \\
\hline Tbl. 16 & Criticality_Inventory.xlsx & $\begin{array}{l}\text { Relative differences } \\
\text { total mass basis }\end{array}$ & Same as above \\
\hline Tbl. 17 & Criticality_Inventory.xlsx & $\begin{array}{l}\text { Relative differences iso } \\
\text { basis }\end{array}$ & Same as above \\
\hline Tbl. 18 & Criticality_Inventory.xlsx & $\begin{array}{l}\text { Relative differences iso } \\
\text { basis }\end{array}$ & Same as above \\
\hline Tbl. 19 & 252g_vs_56g.xlsx & Sheet3 & $\begin{array}{l}\text { W17x17_e8_252.inp (Polaris) } \\
\text { origen/W17x17_e8_b80G_252.inp (ORIGEN) }\end{array}$ \\
\hline
\end{tabular}

